Portland State University

PDXScholar

$5-20-2013$

\title{
The Metropolitan Dimensions of United States Immigration Policy: A Theoretical and Comparative Analysis
}

Nicole G. Toussaint

Portland State University

Follow this and additional works at: https://pdxscholar.library.pdx.edu/open_access_etds

Part of the Social Policy Commons, and the Urban Studies Commons Let us know how access to this document benefits you.

Recommended Citation

Toussaint, Nicole G., "The Metropolitan Dimensions of United States Immigration Policy: A Theoretical and Comparative Analysis" (2013). Dissertations and Theses. Paper 1065.

https://doi.org/10.15760/etd.1065

This Dissertation is brought to you for free and open access. It has been accepted for inclusion in Dissertations and Theses by an authorized administrator of PDXScholar. Please contact us if we can make this document more accessible: pdxscholar@pdx.edu. 
The Metropolitan Dimensions of United States Immigration Policy:

A Theoretical and Comparative Analysis

by

Nicole Toussaint

A dissertation submitted in partial fulfillment of the requirements for the degree of

Doctor of Philosophy

in

Urban Studies

Dissertation Committee:

Carl Abbott, Chair

Kimberley Brown

José Padín

Gerry Sussman

Portland State University

2013 
(C) 2013 Nicole G. Toussaint 


\begin{abstract}
Municipal unauthorized immigration policy, as an area of study, is underexplored. The literature is in the early stages of development, and little specific theory to guide research exists. To advance this emerging field, my study addresses two questions. First, what unauthorized immigration policies do local governments pursue, under what circumstances, and for what reasons? Second, what explains city-to-city variation in municipal responsiveness to the policy preferences and interests of residents without legal status?
\end{abstract}

The dissertation also presents a typology of municipal responsiveness to unauthorized immigrants, based on my exploratory research. To explain intercity differences in the policy processes and choices of local government, I explore three possible explanations--Hero's (1998) social diversity thesis, urban regime theory, and political culture and policy entrepreneurship. My study engages these theoretical ideas with the findings of a comparative case study of three mid-size, reemerging gateway cities: Sacramento, California; Denver, Colorado; and Portland, Oregon. I explore whether associations between local factors and municipal unauthorized immigration policy emerge in the recent history of the three case cities.

Analysis of data gleaned from document study suggests that political culture, as expressed through entrepreneurial political leaders, has been important in shaping regime development and subsequent policy action on unauthorized immigration, while differences in the ethnoracial structure of cities accounts for variation in policy approach. 


\section{ACKNOWLEDGMENTS}

The names of four people appear on the cover of this dissertation along with mine. I am immensely grateful for their contributions to this important piece of my life. My deepest gratitude is to my advisor, Dr. Carl Abbott. He gave me the freedom to explore on my own and the guidance to recover when my steps faltered. His thoughtful consideration of my life circumstances, quick feedback, and editorial support enabled me to overcome this final hurdle to complete my doctoral degree. I cannot adequately express my appreciation for your enduring support throughout this long process, Dr. Abbott. So, in the words of William Shakespeare, "I can no other answer make, but, thanks, and thanks."

To Dr. José Padín...my sincere thanks for helping me recognize and evaluate complex correlations in my data. Your expertise in this area helped me focus my ideas so I could contribute new knowledge to key questions in the field. To Dr. Kimberley Brown...thank you for carefully reading and commenting on various revisions of this manuscript. I appreciate you for urging the use of correct grammar and consistent citations in my writings, and also for your kind words of encouragement during stressful times. To Dr. Gerald Sussman...thanks for commenting on my views and helping me understand and enrich my ideas. I am especially grateful for your review of my methodology, and advice on how to present comparative data. For holding me to a high research standard, I am indebted to everyone on my patient dissertation committee. Most importantly, for this most amazing day, I thank God and my beloved husband, Dixie Worthington, for believing in me and answering when I called. 


\section{TABLE OF CONTENTS}

ABSTRACT

The Problem of Municipal Immigration Policy.............................. 1

Definitions

Research Strategy.

Dissertation Organization. ...

2. LITERATURE REVIEW ............................................. 17

Dimensions of Municipal Immigration Policy............................ 17

Determinants of Municipal Immigration Policy......................... 22

Study Purpose and Rationale......................................... 37

Research Propositions................................................ 40

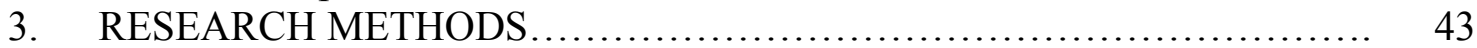

Multicity Policy Exploration.............................................. 43

Typology Construction............................................. 44

The Exploratory Research Process................................ 48

Case Study Methods............................................... 51

Typology Construction........................................... 51

The Case Study Research Process................................ 54

Comparative Data Analysis........................................ 61

Theoretical Evaluation............................................ 61

4. THE RANGE OF POLICY: A MULTICITY EXPLORATION................ 63

Issue Briefs.......................................................... 63

Asylum for Unauthorized Refugees................................ 64

Amnesty for Unauthorized Immigrants............................ 66

Worksite Deportation Raids....................................... 69

The Devolution of Immigration Law Enforcement..................... 73

Government Benefits for Noncitizens.................................. 78

"Locally Legal" Identification Cards................................... 85

Unregulated Day Labor-Contractor Market Exchanges................... 89

Typology of Municipal Unauthorized Immigration Policy................ 91

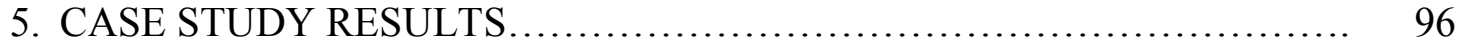

Sacramento, California.............................................. 96

Denver, Colorado..................................................... 145

Portland, Oregon................................................... 193

6. COMPARISON AND THEORY EVALUATION ......................... 237

Intercity Policy Similarities and Differences............................ 237

Exploring Theoretical Expectations................................... 239

Lessons Learned................................................. 247 
7. CONTRIBUTIONS, LIMITATIONS, AND FUTURE DIRECTIONS ....... 250

Multicity Policy Exploration............................................ 250

Multiple Case Study Research....................................... 252

REFERENCES ....................................................... 256

APPENDICES...................................................... 326

A. A Checklist of Potential Municipal Immigration Strategies............ 327

B. A Typology of Municipal Unauthorized Immigration Policies.......... 332 


\section{LIST OF TABLES}

Table

1. Policy Evaluation Criteria and Score................................ 53

2. A Typology of Municipal Responsiveness to Unauthorized Immigrants..... 54

3. Comparison of Case City General Population Characteristics............... 55

4. Comparison of Case City Foreign Born Population Characteristics.......... 55

5. Comparison of Case City Population Characteristics by Race/Ethnicity..... 56

6. Comparison of Changes in Case City Race and Ethnic Characteristics....... 56

7. Comparison of Case City Socioeconomic Characteristics.................. 57

8. Comparison of Cast City Geographic and Political Characteristics.......... 57 


\section{CHAPTER 1}

Introduction

\section{The Problem of Municipal Immigration Policy}

Municipal immigration policy is happening all around us, but it is ad hoc from city to city and not well understood. For example, in 2008 federal immigration agents scooped up and incarcerated 20 percent of Postville, Iowa's population of 2,300 in a raid at local kosher meat processing plant. The near-demise of the town that followed after the plant declared bankruptcy was documented on CBS News. Correspondent Seth Doane issued this report on the raid's impact:

With empty streets and shuttered shops, this small town is facing economic calamity. Mayor Bob Penrod is taking steps this weekend to declare a state of emergency here. But it's not a natural disaster. Rather, one that's manmade... (Drennen, 2009, para. 3).

A story in the Washington Post detailed allegations made by townspeople against Immigration and Customs Enforcement (ICE) for targeting workers instead of CEOs (Hsu, 2008). A month later, USA Today ran a story about three West Coast mayors who got their colleagues in the U.S. Conference of Mayors to challenge the way government raids businesses in search of illegal workers. Local leaders complained about sweeps hurting regional economies by forcing companies to relocate (Bazar, 2008). 
San Francisco's position on immigration raids is captured in this April 27, 2007

New York Times national news brief:

Police officers and other city employees will not help federal immigration authorities seeking to round up and deport illegal immigrant workers in San Francisco, Mayor Gavin Newsom said Sunday. The mayor told a predominantly Hispanic audience... that while city and state officials could not stop Immigration and Customs Enforcement from conducting sweeps in the city, he would do everything within his power to discourage them. 'We are a sanctuary city, make no mistake about it' (“City Won't Aid," 2007, para. 1)

In 2008, Mayor Newson launched an $\$ 83,000$ taxpayer-funded public awareness campaign to promote the city's "sanctuary" policy to undocumented residents. Ad packages come in different languages, but the message was the same: San Francisco will not report you to federal immigration authorities (McKinley, 2008). The public service announcement--published in brochures, broadcast across the airwaves and on YouTube-was not breaking news. ${ }^{1}$ San Francisco's sanctuary ordinance, which prohibits city employees from helping federal authorities with civil immigration investigations or arrests, was adopted nearly two decades ago. Still, it never hurts to advertise, Mayor Newson told a New York Times bureau chief (McKinley, 2008).

According to city officials, unauthorized residents stopped using city services, reporting crimes, and sending children to school after the raid in San Francisco (McKinley, 2008). The outreach program was the intended remedy. Meanwhile a new municipal ID card streamlines access to city programs and services for residents who do not have a state-issued driver's license (McKinley, 2008). San Francisco is not alone in its sanctuary status; New York, Detroit, Chicago and hundreds of other cities have

\footnotetext{
${ }^{1}$ The PSA is posted on YouTube at http://www.youtube.com/watch?v=BMzsUo2aM4U.
} 
policies that protect their residents from deportation; a decision encouraged by the sanctuary movement. ${ }^{2}$

Other cities have done the exact opposite. Political commentator and Los Angeles Times blogger Andrew Malcolm remarked on the "unwelcome sign" Costa Mesa, California put out: “Mayor Allan Mansoor...not only doesn’t welcome illegal immigrants but doesn't want them and is, in fact, a 'rule-of-law city' that will enforce immigration laws strictly" (Malcolm, 2010, para. 4). In 2010, Mr. Mansoor persuaded the city council to pass a resolution stating that Costa Mesa is not sanctuary city.

Residents of Prince William County, a Virginia suburb of Washington DC, are still arguing about the consequences their Rule of Law Resolution (Khan \& Sridhar, 2008). ${ }^{3}$ The 2007 policy empowers police to ask about the legal status of suspected "illegal aliens" alleged to have violated a municipal law or ordinance. It also expands the county's participation in ICE's $287(\mathrm{~g})$ program, which deputizes local law enforcement officers to act as immigration agents. ${ }^{4} N B C$ News 4 's Julie Carey says the ordinance helped shape Arizona's controversial immigration law (Carey, 2012).

According to the Washington Times, Supervisor John Stirrup introduced the resolution in response to accusations that the county employed so-called "sanctuary" policies protecting illegal aliens ("Prince William," 2007). Prior to adopting the Rule of Law Resolution, police were prohibited from questioning suspects about their

\footnotetext{
${ }^{2}$ The sanctuary movement is a campaign by religious groups to designate U.S. cities as sanctuaries for unauthorized immigrants.

${ }^{3}$ Proponents claim the measure, which targeted day laborers, has reduced crime and improved the quality of community life. Opponents say it caused immigrants to flee the county, leaving neighborhoods dotted with vacant houses and sowing distrust of authorities without reducing crime

${ }^{4}$ In 2008 , the original resolution was modified so now all persons arrested are subject to a check of their status, not just suspected undocumented immigrants; performing checks on suspects who are not arrested is left to the discretion of the officer.
} 
immigration status unless they had committed a felony violation ("Prince William,"

2007). The Washington Post issued this report on the measure's development:

The Federation for American Immigration Reform, and its legal affiliate the Immigration Reform Law Institute, helped write both the Arizona and Prince William County laws and are working on similar legislation for other jurisdictions (Bahrampour, 2010, para. 11).

Film maker Eric Byler captured local government's vulnerability to national antiimmigration networks in 9500 Liberty, a documentary about immigration politics in Prince William County. Citizens used YouTube videos and virtual town hall meetings to repeal the town's notorious immigrant law.

$N P R$ 's Jennifer Ludden issued this report on the efforts of anti-illegal immigrant activists in another Northern Virginia town:

Herndon will close a controversial worker center for immigrant day laborers. The center was hardly the first of its kind, but Herndon became a high-profile test case when activists against illegal immigration sued the town for publicly funding the site (Ludden, 2007, para. 1).

A Washington Times report provides details on the lawsuit filed by Judicial Watch, a conservative public interest law firm:

The group... asks a judge to declare the [day labor hiring] site 'unlawful and a violation of federal and state law' because the center will 'predominantly' serve aliens...the lawsuit also questions whether the center is in violation of a new Virginia law that denies illegal aliens state and local benefits ("Judicial Watch," 2005, para. 3, 5).

Judicial Watch argued that employment services qualify as public assistance, and rentfree use of the town property equates to a taxpayer subsidy. In the meantime, Herndon voters, encouraged by the Arizona-based Minutemen Project, ousted the mayor and city 
council members who supported the day labor center and elected new leaders who shut it down (Turque \& Stewart, 2006).

Suffolk County executive Steve Levy, co-founder of a national coalition called Mayors and County Executives for Immigration Reform, drafted legislation to rid Brookhaven, New York of illegal day laborers (Lambert, 2006). USA Today covered "Operation Firestorm," a 2005 campaign that resulted in the eviction of more than 100 Latino men from overcrowded housing in the town (Willens, 2006). A religious leader, quoted in the New York Times, accused Levy of "ethnic cleansing" (Lambert, 2005). This quotation, in Merlene Davis' Lexington Herald column, succinctly sums up the situation: "My country, maybe, my neighborhood, no way" (Davis, 2006, p. D1). ${ }^{5}$

Battles over illegal immigration go beyond cities at the epicenter of debate, like San Francisco and Hazelton, Pennsylvania. ${ }^{6}$ In 2009, deportation furor caught an unwilling Texas mayor in the middle. Community conflict in suburban Irving was documented in the New York Times. Journalist Randy Kennedy issued this report in April on the city's response to unauthorized immigration and the fallout:

As battles over illegal immigration rage around the country, Irving's crackdown is not unusual in itself. What makes it striking is that it happened with the blessing of a mayor like Mr. Gears, an immigrant-friendly Democrat with deep political ties to the city's Hispanic leaders, a man who likes to preach that adapting to immigration... is not a burden but an opportunity, or as he says, it's 'not a have-to, it's a get-to' (Kennedy, 2009, para. 5).

\footnotetext{
${ }^{5}$ Merlene Davis was quoting a message written on a note attached to a burning cross on the lawn of an immigrant household.

${ }^{6}$ In 2006, Hazleton gained national attention when the Republican mayor and council members passed the Illegal Immigration Relief Act, which was instituted to discourage hiring or renting to illegal immigrants. Other cities replicated the ordinance.
} 
Mayor Gears won re-election against an opponent whose campaign promised tough immigration measures. But as a wave of anti-illegal sentiment built around Dallas and the nation, Mr. Gears realized his city would no longer be able to remain on the sidelines-and that his own political future depended on his response (Kennedy, 2009). Heeding public pressure, two years ago Gears made an agonizing decision. He adopted the federal cooperation program for residency checks inside the local jail (Kennedy, 2009. It was a "public turning point in the political reorientation of Mr. Gears," a New York Times reporter observed (Kennedy, 2009, para. 30).

Four thousand locals were deported as a result. Only 850 were charged with violent crimes or other felonies. Well over half of the deported had been arrested for public intoxication or not having a driver's license. The town became deeply divided over the issue. Mayor Gear's friend is leading the campaign against the jail policy (Kennedy, 2009).

The story of Mayor Herbert A. Gear is one of the many newspaper reports about the growing number of U.S. cities where immigration control, a federal prerogative, is reshaping politics at the local level (Kennedy, 2009).

Still, this phenomenon, while important on the ground, is not well studied, an odd fact given that the Department of Homeland Security (DHS) estimates that between 2000 and 2010 the unauthorized population in the United States grew by 27 percent, to 10.8 million (Hoefer, Rytina \& Backer, 2011). ${ }^{7}$ The impact is felt first and foremost in cities. In response, local governments have become increasingly autonomous in their responses

\footnotetext{
${ }^{7}$ Of all unauthorized immigrants living in the United States in 2010, the DHS reports 39 percent entered in 2000 or later, and 62 percent were from Mexico.
} 
to the challenges and opportunities of unauthorized foreign in-migration, as media accounts point out. More research is needed to help us understand this increasingly important dimension of immigration policy. ${ }^{8}$

In a broad sense, these municipal actions are a category of municipal foreign policy. International relations scholarship establishes that City Hall's involvement in unauthorized immigration politics is part of a larger trend that began in the 1980s (Shuman, 1986-87; Hobbs, 1994). Then, hundreds of local governments got involved in their own international policy pursuits. These municipalities added defense policy, international trade, and immigration to the catalog of issues that urban and suburban politicians contend with. ${ }^{9}$ Two examples of municipal unauthorized immigration policy are highlighted in this literature: sanctuary resolutions for Central American refugees (Hobbs, 1994), and anti-Patriot Act resolutions (Hobbs, 2004). ${ }^{10}$ Kresel \& Fry (2005) classify both as municipal foreign policy, which entails city officials directly formulating and implementing their own version of foreign policy that is not approved by the national government, and, in fact, advocates noncompliance with federal laws and noncooperation with federal law enforcement authorities. ${ }^{11}$

\footnotetext{
${ }^{8}$ This conclusion is supported by the marked, ongoing overlap between migration research and urban studies research. The Urban Institute, the Mumford Center for Urban and Regional Research, and the Brooking Institute's Center on Urban Metropolitan Policy produce primary research on U.S. immigration trends and policy. Both Canada and the United States participate in the International Metropolis Project, which produces policy-relevant research on migration and immigration in urban settings (Abu-Laban \& Garver, 2005).

${ }^{9}$ These policies emerged from progressive cities encouraged by national lobbying groups.

${ }^{10}$ Components of both measures protect unauthorized community members from deportation, a right denied them by the U.S. government.

${ }^{11}$ Kresel \& Fry (2005:49) identify two other forms of municipal international policy: (1) municipal foreign affairs (e.g. trade investment missions, hosting profile-raising world conferences, twinning partnerships with foreign cities, and inter-municipal cooperation on public projects); and (2) municipal maneuvers that fall into the "gray area" between foreign affairs and foreign policy, which they characterize as attempts by local government to effectuate change in a nation's foreign policy by working through traditional
} 
A few scholars have explored the role of state and local government in making and implementing immigration policy early in United States history (Skerry, 1995; Neuman, 1996). Contemporary scholarship focuses on the explosion of state and municipal responses to unauthorized immigration that begun in the 1980s. The most vigorous debates and discussions on the topic have taken place in law reviews. Legal scholars are divided over the issue of "immigration federalism." 12

Those arguing against state and local involvement in the immigration regime say it violates the Supremacy Clause and is unconstitutional (O'Byrne, 2008). Other opponents raise concerns about the potential for racial profiling and violation of longestablished constitutional safeguards like due process, free speech and equal protection (Chishti, 2002; Pham, 2004; Sullivan, 2009; Rodríguez, Chishti, Nortman, 2010).

Those in favor of immigration federalism highlight the national securityenhancing dimensions of state and local immigration enforcement (Hethmon, 2004; Kobach, 2005-2006). These scholars view the devolution of immigration authority as a crucial "force multiplier" in the war on terror. Others make a case for the structural necessity of a multilayered immigration regime (Huntington, 2008; Rodríguez, 2008). Rick Su (2010) argues that state and local immigration measures allow for finer regulatory controls than the one-size-fits-all policy that can be implemented at the national level. These "second-order immigration regulations," as he calls them, also provide a means by which, in the absence of a national consensus, the competing interests

channels - the national court system or their representatives in Congress - rather than breaking the law in order to do it.

${ }^{12}$ Hioshi Motomura (1999) first coined the term "immigration federalism," which refers to subnational immigration policymaking. 
surrounding immigration can still be negotiated and regulated" locally ( $\mathrm{Su}, 2010$, p. 370).

From this perspective, the federal-municipal immigration dichotomy is false one: national and local immigration controls are integrated, complementary parts in the same regulatory system.

This legal scholarship sheds light on the legality and wisdom of emerging state and local immigration policies. Still, most of the discussion on immigration and federalism, as Anil Kalhan (2008) points out, has centered on immigration regulation and enforcement. The potentially "liberty-enhancing" dimensions of federalism and localism have not been adequately considered, he argues. The role that state and local governments might play in protecting the rights and liberties of non-U.S. citizens, Kalhan says, needs to be explored.

\section{Definitions}

There is no single accepted definition of this new policy trend and the terminology is various. "Subnational immigration policy" and "local immigration policy activism" is the language used most often in the field. My working definition of municipal immigration policy is any program of actions adopted or proposed by local authorities that affects the well-being and life opportunities of first generation foreign inmigrants ${ }^{13}$ (lawfully or unlawfully) present within a city's jurisdiction, or attempting to settle in it. Municipal immigration policy (MIP) also refers to the process of making

\footnotetext{
${ }^{13}$ I use the term 'foreign in-migrant' to refer to someone who leaves the country in which he or she was raised and moves to a new country for an extended period of time. Based on this definition there are six types of foreign in-migrant groups: nonimmigrant sojourners (e.g., international students, exchange visitors, missionaries, treaty traders and investors); temporary workers (e.g., highly skilled specialty workers who enter on H-1B visas, and agricultural and nonagricultural workers at the other end of the economic ladder who are admitted on $\mathrm{H}-2$ visas); refugees and asylees; permanent immigrants (i.e.,
} 
important public decisions, including the identification of alternatives such as programs or spending priorities, and choosing among them on the basis of the impact they might have on a city's new foreign-born residents.

Like all urban policy, municipal immigration policy has many facets, which are a topic of discussion in recent concept papers and legal reviews. In this scholarship MIP is generally characterized as local immigration control measures or urban citizenship policy. ${ }^{14}$

I understand local immigration control policy as programs of actions adopted or proposed by a municipal government to regulate or restrict the flow of unauthorized immigrants into a city's jurisdictional boundaries, or expel settled foreign community members without documents. These deter and deflection policies, as they are sometimes called, encourage unauthorized foreign nationals to self-deport, or otherwise move on to other cities within the country (Light, 2006). This is an objective typically achieved by denying people without legal status the rights and entitlements of citizenship, including the right to live in the country without fear of deportation.

Urban citizenship policies are steps taken by city government to naturalize unauthorized community members. The process involves guaranteeing "illegal aliens" formal membership in a city's polity, and with that, the civil rights and liberties

migrants granted admittance and permanent residence status by the federal government); and federally designated "illegal" migrants (i.e., those individuals who overstay or violate their visas, and those that cross the border without being inspected by an immigration officer at a port of entry).

${ }^{14}$ MIP is occasionally conceptualized as internationalization policy, immigrant-driven community development actions that involve recruiting specific foreign nationals to advance a city's status, stabilize or spur population growth, and/or meet its service demands ( $\mathrm{Su}, 2010)$. 
associated with citizenship. ${ }^{15}$ Relief from deportation is one of those rights, a goal accomplished by enacting sanctuary policies. ${ }^{16}$ Sanctuary policies are official and unofficial measures initiated to inhibit the local enforcement of federal civil immigration laws. Immigration law scholar Orde Kittrie characterizes modern sanctuary policies as three types: (1) “don’t ask" policies that limit inquires related to nationality and immigration status; (2) “don't enforce" policies that limit immigration-related arrests and detentions; and (3) "don't tell" policies that limit what information local enforcement officers may share with federal officials (Sullivan, 2009, p. 574 ).

This new form of policymaking differs significantly from customary Chicago School conceptualizations of local immigration policy as municipal settlement measures, strategies designed to incorporate legal immigrants and refugees into mainstream urban life, or efforts to marginalize the same. Locally-generated immigration control and naturalization policy, are "local membership" policies. They "define who is or is not permitted to be members of 'our' communities, and furthermore, what legitimate membership means" (Varsanyi, 2007) and who should get to decide this. Settlement policy is domestic policy. ${ }^{17}$ Municipal solutions to unauthorized immigration issues are foreign policies. ${ }^{18}$

\footnotetext{
${ }^{15}$ The idea of local citizenship has been discussed in a number of concept papers (Bauböck, 2003; Varsanyi, 2006, 2008; Anderson, 2011).

${ }^{16}$ The government cannot refuse citizens entry into the country or deport them.

${ }^{17}$ With the exception of legally recognized refugees, the U.S. government does not concern itself with newcomer settlement; there is no federal immigrant policy to meet the social, physical, civic, and integation needs of immigrants and receiving communities. Decisions about the well-being and safety of foreign immigrants are left up to municipalities. The primary focus of the federal government is on controlling the flow of immigrants and policing the country's borders (Abu-Laban \& Garber, 2005; Bloemraad, 2006). ${ }^{18}$ In the United States immigration policy is considered foreign policy. Foreign policy refers to the ways a government advances its interests in international politics.
} 
According to Kresl \& Fry (2005), most large, medium, and even small cities engage in some form of municipal foreign affairs-local government activities which transcend national boundaries in an effort to protect or enhance the economic interests of their constituents. Fewer city officials are involved in more controversial municipal foreign policy_directly formulating and implementing their own versions of foreign policy which advocates disobeying federal authority. More common are municipal maneuvers that fall into the "gray area" between foreign affairs and foreign policy. This type of municipal action decries a national government's international pursuits, but does not advocate breaking the law in order to protest these initiatives (Kresl \& Fry, 2005, p. 49).

Local immigration controls and urban citizenship policy fall all along the municipal foreign affairs - foreign policy continuum. Local government decisions on Mexican CID cards, or sister city relationships formed to protest U.S. asylum policy, are examples of foreign affairs activities. ${ }^{19}$ Both measures are municipal agreements with foreign governments.

City "sanctuary" ordinances and homegrown versions of the Illegal Immigrant Relief Act, ${ }^{20}$ fit Kresl \& Fry's (2005) definition of municipal foreign policy. These are direct action initiatives that exceed, without federal permission, the traditional legal scope of municipal immigration authority and are intended to do one of two things: (1) prevent federal authorities from performing some practice to which activist cities object (e.g., enforcing IRCA with worksite deportation sweeps or denying noncitizens access to

\footnotetext{
${ }^{19}$ Municipal internationalization policy fits into the municipal foreign affairs category.

${ }^{20}$ The Illegal Immigrant Relief Act is a local version of the U.S. Immigration Reform and Control Act of 1986 (IRCA). Both laws punish employers for hiring immigrants without documents.
} 
government benefits); or (2) to solve a perceived immigration problem which the federal government is not addressing to the satisfaction of direct action participants (e.g., fining employers who hire illegal aliens).

Municipal regulations that encourage real or imaged "illegal" day laborers to selfdeport (e.g., anti-solicitation and anti-stacking ordinances, which prevent undocumented migrants from seeking work or finding housing) fall into the "gray area" of Kresl \& Fry's (2005) framework. These indirect, conventional forms of MIP are within the legal bounds of traditional municipal authority. Even so, recent court rulings indicate some are unconstitutional if they discriminate.

In practice, local authorities use a variety of conventional and unconventional tactics to achieve their immigration-related policy objectives. Depending upon the city, these measures either advance or hinder the rights and opportunities of urban residents without legal status.

Research Strategy

The dissertation addresses two questions. First, what unauthorized immigration policies do local governments pursue, under what circumstances, and for what reasons? Second, what explains city-to-city variation in municipal responsiveness to the policy preferences and interests of residents without legal status?

The study also presents a typology of municipal responsiveness to unauthorized immigrants, based on my exploratory research. To explain intercity differences in the policy processes and choices of local government, I explore three possible explanations-Hero's (1998) social diversity thesis, urban regime theory, and political culture and 
entrepreneurship. My study engages these theoretical ideas with the findings of a comparative case study of three mid-size, reemerging gateway cities: Sacramento, California; Denver, Colorado; and Portland, Oregon. ${ }^{21}$ I explore whether associations between local factors and municipal unauthorized immigration policy emerge in the recent history of the three case cities. Analysis of data gleaned from document study suggests that neither social diversity nor urban regime development explains intercity variations in municipal immigration policy. However, political culture as expressed through entrepreneurial political leaders has been important in shaping these policies.

This research has implications for urbanists and immigration specialists, as well as researchers and scholars of international studies, political science, sociology, law and geography. Those involved in public policy, government administration, municipal leadership, urban planning and grassroots organizing will also find it relevant. Research findings could ensure a stronger role for local government in determining federal immigration policy, or guide stalled national reform efforts.

${ }^{21}$ In this work, I separate central city from its suburbs and focus only on the former as distinct political units. 


\section{Dissertation Organization}

The rest of the dissertation is organized as follows. In Chapter 2, I analyze what has already been written in the field and identify the research that still needs to be done. This critique is followed by my research rationale and the main premises of the study.

Chapter 3 lays out the research questions and expectations. It explains my twopronged research approach. The explorative study is detailed first. Then, I describe in detail how I conducted my comparative case study, and explain the criteria used to select and evaluate the three case cities.

Chapter 4 presents the results of my multi-city policy exploration. It begins with a summary of the most hotly contested immigration issues arising in U.S. cities over the past two decades, all of which pertain to "illegal" immigration. Next, I present my typology of municipal response to unauthorized immigration issues and summarize key findings.

Chapter 5 provides a detailed, contextualized description of local government action on unauthorized immigration in three U.S. cities--Sacramento, California; Denver, Colorado; and Portland, Oregon--between 1985 and 2010. I focus on municipal response to the six locally important immigration debates described in Chapter Four.

In Chapter 6, I compare municipal response to unauthorized immigration in the three case cities and do theory evaluation. The chapter starts with a description of the similarities and differences between the immigration strategies of local governments in Sacramento, Denver and Portland. It goes on to explore the theoretical expectations 
presented in the study to see if correlations emerge in the data, and ends with a list of lessons learned.

Chapter 7 summarizes the research questions and findings of the dissertation. Theoretical and policy implications are discussed, as are current study limitations and future research directions. 


\section{CHAPTER 2}

\section{Literature Review}

In this chapter, I draw on existing scholarship to describe the dimensions of municipal immigration policy and utilize earlier studies to identify three explanatory frameworks for understanding the emergence and character of these policies. This analysis provides the basis for my research rationale and the explanatory propositions that I explore through in-depth case studies.

\section{Dimensions of Municipal Immigration Policy}

Scholars have worked to identify and categorize the de facto roles that local government plays in the immigration regime, which is basically to adjust federal policy in accordance with local interests. Miriam Wells (2004) documents the way cities involved in the late-twentieth-century sanctuary movement shifted the outcome of federal immigration policy on the ground through noncompliance, a process she calls the "grassroots reconfiguration" of U.S. immigration policy. Local governments in these socalled "sanctuary cities" were the first adopters of municipal citizenship policies: city of refuge resolutions, limited police-INS cooperation ordinances, raid-free zone MOU agreements, and city social welfare guarantees for unauthorized residents. ${ }^{22}$

\footnotetext{
${ }^{22}$ A sanctuary city is a locality that has taken steps to protect its "illegal" foreign in-migrant population from discrimination and deportation by federal agents.
} 
Wells traces the emergence of local policy activism to an expectation gap ${ }^{23}--a$ contradiction between the federal government's responsibility to exclude illegal aliens (by rejecting asylum applications, cutting public benefits, and conducting deportation raids), and municipal government's moral and municipal obligation to provide for the welfare of all of its urban residents.

An unfair application of restrictive immigration laws ${ }^{24}$ produced this conflict of interest which, in turn, triggered direct action from leaders involved in the immigration sanctuary movement. These leaders, advocating the principles of immigrant/ethnic/labor/civil rights, secured enough coalition support to pressure local officials and regional INS directors to exercise the discretionary power granted them by the federalized U.S political structure ${ }^{25}$ to protect the rights of residents without legal status. Local government initiated ordinances limiting local immigration enforcement. Regional INS directors signed no-raid agreements. The protest sequence ${ }^{26}$ occurred in a number of other cities where constituents hold inclusive perspectives on the membership

\footnotetext{
${ }^{23}$ The expectation gap thesis, a mainstay of presidential literature, is the idea that there is a gap between public expectations of Congress and the president and what Congress and the president actually do, or the public perceives they can do (Jenkins-Smith, Silva \& Waterman, 2005). If the public believe their representatives are supposed to be responsive to the policy preferences of local citizens, when they are not the public is disappointed with government's performance.

${ }^{24}$ Those laws were: the Refugee Act of 1980, Immigration Reform and Control Act of 1986 (IRCA), and Welfare Reform Act of 1996.

${ }^{25}$ The multifaceted, ambiguous, and internally contradictory structure of the U.S. political structure allows for "alternative interpretations and concretization of federal policy" (Wells, 2004, p. 1310).

${ }^{26}$ According to Smelser's (1963) structural strain theory, six conditions underlie the origins of social movement action: 1) structural conduciveness (the U.S. political system leaves openings for the mobilization of protest), 2) structural strain (contradictions that produce frustrating conflicts of interest), 3) generalized beliefs (that crystallize collective grievances and suggest courses for remedy), 4) precipitating factors (events that trigger direct action by those involved in the movement), 5) leadership (coordinated groups mobilize for action), and 6) operation of social control (governing authorities respond by intervening in the condition of conduciveness that gave rise to the movement).
} 
of unauthorized immigrants, and city officials are willing to assume a responsibility abdicated by the federal government - to protect the individual rights of all people.

Ivan Light (2006) documents how Los Angeles and, by interference other firstreception cities in the First World, took on migration control responsibilities during the late-twentieth-century. Local officials assume this policymaking role, he argues, when they decide how much poverty to tolerate. When municipalities tolerate poverty, then the network-driven influx of immigrants continues. When they enforce previously ignored laws and ordinances (against slums, sweatshops, and other non-middle class lifestyle standards) the local influx slows. Light calls this program of action "sequential absorption and deflection policy" (p. 13).

Sequential absorption and deflection is a process whereby first-reception cities receive immigrants, absorb as many as they can decently house and employ, and then deflect unwanted others to second-settlement reception areas which repeat the process. According to Light (2006), this strategy becomes default policy when:

The national government will not or cannot constrain influx to manageable levels, support first-reception areas with targeted relief for their exceptional burdens, or effect long-term immigration's equal dispersion over the national terrain (p. xi).

Under these conditions fed up suburban NIMBYists, and well-meaning social justice activists, push local government to act autonomously instead of waiting for a national solution.

Monica Varsanyi $(2006,2007)$ has a slightly different take on the role of local government in the international migration arena. She claims the formulation of municipal membership policies (locally-generated immigration control and naturalization policy) 
helps the nation-state negotiate--what political theorist James Hollifield calls, the "liberal paradox," or the "growing tension between neoliberal openness and the continued necessity of national political closure" (Varsanyi, 2007, p. 300). She offers the widely accepted matrícular consulares as evidence. These Mexican identification cards, which document undocumented migrant workers, offer the perfect solution: they enable an exploitative situation in the interior, while the federal government focuses on tougher border control.

The greater part of social science literature simply documents and describes the policy pursued during a second explosive wave of municipal immigration policy activism in the late 2000s. These measures can be categorized as: (1) policies enabled by the devolutionary power of federal legislation, like 287(g) and Security Community agreements (Thacher, 2005; Coleman, 2007; Waslin, 2007); ${ }^{27}$ and (2) policies proposed and adopted by local government. Homegrown actions, which can be either proimmigrant or anti-immigrant, are intended to do one of two things: (1) prevent federal authorities from performing some practice to which activist cities object (e.g., enforcing IRCA with worksite deportation sweeps or denying noncitizens access to government benefits); or (2) solve a perceived immigration problem which the federal government is not addressing to the satisfaction of direct action participants, like discouraging entry of "illegal" immigrants or regulating informal day laborer-contractor market exchanges.

\footnotetext{
${ }^{27}$ The devolution of immigration policing authority from federal to state and local government stems from these factors: (1) the 1996 passage of IIRCA and PRWORA that allowed police and sheriffs to partner with ICE on the interior enforcement of civil immigration laws, which involves the detection and deportation of settled immigrants; and (2) Attorney General John Ashcroft's 2002 memorandum authorizing local police to enforce civil immigration laws, and encouraging their participation in the "War in Terrorism."
} 
Some of these unauthorized immigration initiatives are planned and executed openly, like policy pertaining to noncitizen voting, limited INS-police cooperation ordinances, employer sanctions, and Illegal Immigrant Relief Acts (Hayduk, 2006; Varsanyi 2005, 2006, 2007; Ridgley, 2008). Others are disguised as general population measures. Land use and zoning ordinances used to regulate day laborers (Esbenshade, 2007; Varsanyi, 2008), or minimum wage laws (Mitnik \& Halpern-Finnerty, 2010), fit into this category. While these undercover policies do not appear geared towards residents without legal status, members of that group are disproportionately affected. Mitnik \& Halpern-Finnerty's (2010) national policy survey indicates that local authorities in the United States use a variety of "immigrant-specific" and "nonimmigrant-specific" tactics to achieve their policy objectives. Noting that sometimes city officials propose or adopt new legislation, while other times they simply enforce existing state, regional or local regulations that were not originally intended to address immigration, but have that effect. Laws prohibiting slums and sweatshops are illustrative of this approach.

Broad, multi-city policy overviews shed light on the range of tactics that city governments use to address unauthorized immigration issues. Still, most data comes from patchy secondary sources--other scholars or non-refereed reports issued by nonprofit think tanks, civil rights organizations, and special interest groups. ${ }^{28}$ More research is needed to verify and expand this data set. Missing examples are probable. For instance, the existing database is narrowly focused on four areas of traditional municipal authority: lawmaking, law enforcement, urban land use and planning, and the provision of public

\footnotetext{
${ }^{28}$ Migration Policy Institute, National Immigration Law Center, Puerto Rican Legal Defense Fund, Federation for Immigration Reform, National Employment Law Project, Day Labor Research Institute, Bill of Rights Defense Committee, the American Civil Liberties Union and others
} 
benefits. Examples of local government exercising its contracting and litigation power, lobbying privileges, finance appropriation and public works authority, property management clout and legal opinion are absent in the literature. So are off-the-record practices, like turning a blind eye to local violations of federal immigration law. These are all likely ways to achieve immigration-related policy objectives.

Another shortcoming of the national overview approach is the propensity to focus on either "immigrant-specific" or "nonimmigrant-specific" policy. Michael Alexander (2004) warns against this, arguing that researchers need to pay attention to all policies that are "initiated or largely determined by the local authority, and have significant impacts on local immigrant populations, either through specific (migrant-targeted) or general (population or area-based) measures" (p. 59). Lack of context is also a problem. None of the studies reviewed provide a comprehensive account of immigration policy activism in a particular city.

\section{Determinants of Municipal Immigration Policy}

Several scholars have offered explanatory frameworks to account for the circumstances and context within which policy activism emerges. This dissertation explores three such frameworks: (1) regime theory, (2) social diversity, (3) political culture and political leadership.

\section{Urban regime factors}

Kristin Good (2005) suggests the importance of urban regime theory for understanding local municipal responses to immigration. She identifies six internal factors that facilitate the formation of a regime with multicultural immigration goals. 
These are: (1) community consensus that immigrants are a problem; (2) a trigger event or overt crisis that puts immigration concerns on the municipal agenda; (3) the immigrant community is well-organized; (4) the city has a long tradition of civil society groups in general, and history of interethnic coalition building in particular; (5) little competition exists between racial/ethnic minorities and immigrants; and (6) local government actively facilitates regime development. The three factors that she suggests prevent municipalities from exercising immigration-related policy action are: (1) immigrants are not perceived to be a problem; (2) no trigger event or overt crisis exists; and (3) immigrant communities are unable to overcome collective action problems. Intercity differences in the way immigrants are viewed, and how ethnoracial power is exercised, underlie these regime development factors.

The urban regime model has been the dominant paradigm in the field of urban politics and policy for more than a decade. According to Mossberger \& Stoker (2001), the concept, which includes elitist and pluralist aspects, has been used to study the incorporation of various interests into governing coalitions —-women (Turner, 1995), lesbians and gays (Bailey, 1999), and African Americans (Stone, 1989; Whelan, Young, \& Lauria, 1994). It has also been used to explain developments in more specific issue areas, like municipal obscenity policy (Bauroth, 1998) and urban school reform (Stone, 1998; Henig et al., 1999).

The conceptual model is based on three main ideas. First, public officials cannot rely on their formal authority alone to carry out their policy agenda. ${ }^{29} \mathrm{~A}$ local government's capacity to govern (undertake major policies and projects) is dependent

\footnotetext{
${ }^{29}$ The formal structure and rules of city government often makes it difficult for local officials to act.
} 
upon its ability to form an urban regime by rallying together key stakeholders through coalition building and leadership strategies.

Second, cohesive governing regimes do not exist in all cities (DeLeon, 1992; Mossberger \& Stoker, 2001). This variation in regime development patterns - present or not present—explains intercity differences in municipal policy outputs (some or none), and the point in time when major policymaking begins.

Third, an urban regime is a stable coalition between local government and private-sector groups (with access to institutional resources) that sets an identifiable policy agenda and collaborates based on social production goals--the need to bring together fragmented resources for the power to accomplish tasks (Mossberger \& Stoker, 2001). ${ }^{30}$ Since urban regimes exist within a political economy framework rather than a pluralist one, governing coalitions that are specifically regimes will include participants from business (Stone, 1989). Beyond the involvement of local government (elected officials and public servants in local agencies) and business, participants in regimes may vary from one city to the next due to differences in urban contexts (Mossberger \& Stoker, 2001).

Finally, different regimes dominate at different times in different cities; a city's policy agenda will reflect the varied preferences of regime partners. ${ }^{31}$ A review of the literature suggests the possibility of three relevant types emerging in governing cities: a corporate regime (also called a development regime), a caretaker regime or maintenance

\footnotetext{
${ }^{30}$ Urban regimes span a number of administrations; ad hoc coalitions pursuing short-term goals do not constitute regime development.

${ }^{31}$ A regime's policy agenda is influenced by the composition of coalition participants and the resources they bring. Since local contexts, which are not fixed, are not the same in cities across the country, regime purpose will vary from one place to the next and may change overtime.
} 
regime, and a progressive regime. Where a development regime holds the most power to carry out policy, local government promotes the growth goals of downtown corporations without concession from other community interests. Caretaker regimes seek to maintain the status quo, either by preserving the quality of life or keeping taxes low. They oppose large-scale development initiatives that would increase taxes or disrupt established patterns of social interaction, and also government allocation of economic development benefits (Clark, 2001). Where maintenance regimes are dominant government focuses on the provision of routine services. Progressive regimes form to secure economic development benefits for various local interest groups or areas of the city. ${ }^{32}$ According to Ross and Levine (2001), there may be two variants of the progressive regime - a middle class and a lower-class progressive regime:

A middle class progressive regime represents the concerns of environmentalists and homeowners in limiting new and costly growth projects. A regime devoted to lower-class opportunity expansion, in contrast, focuses on aiding the poor and racial minorities (p. 73).

Regime types are a useful concept for identifying governing coalitions with immigration-related purposes. For instance, to spur economic growth, a development regime might try to attract firms with a reputation for hiring unauthorized immigrants. Alternatively, a progressive regime, with support from national lobbying groups and/or social movement organizations, could emerge to secure economic development benefits for disadvantaged migrant day laborers, or homeowners worried about "useful invaders"

\footnotetext{
${ }^{32}$ Some scholars question the existence of progressive coalitions, since a regime must be institutionalized to be long-lasting. However, "permanent, city-wide neighborhood organizations may provide a relatively long-term basis for citizen control" of certain types of regimes (Clark, 2001, p. 36). A local social movement organization, or support from a national lobbying group, could serve the same function (Toussaint, 2013).
} 
threatening the quality of their middle-class life. ${ }^{33}$ Either way, if local leaders can build a governing coalition to co-produce policy capacity, that city will have the social production power to take on major initiatives, like local immigration policy. Without such a governing arrangement, little policy will be produced locally.

To summarize, the urban regime concept helps us understand the way power works in urban settings. It correctly predicts the associations between governing coalitions and City Hall's involvement in controversial politics and policymaking. In particular, it explains how local governments gain the capacity to formulate and carry out strategies to cope with economic and social challenges, like unauthorized immigration.

The urban regime model, however, downplays the significance of race and white racism in urban politics. The assumptions of this approach, which are based on a political economy perspective, "maintains that class, not race, is the driving force of urban politics” (Kraus, 2004, p. 96). Adding Hero's (1998) racialized interpretation of state and local politics to the framework addresses this limitation.

\section{Social diversity factors}

Hero's (1998) social diversity thesis posits a relationship between the racial/ethnic composition and configuration of U.S. states (and counties) and the nature of their politics and policy outputs, especially policies that affect minority groups.

The theoretical basis for his argument is rooted in pluralism and race/ethnic relations theory. By integrating these two frameworks, Hero created a foundation for analyzing how the interdependent structures of race and politics combine to shape state

\footnotetext{
${ }^{33}$ Ambrosini (1999) first used the term "useful invaders" to describe immigrant workers who provide "economic benefits and political capital to elites while simultaneously being seen as a threat to dominant cultural values" (Fleury-Steiner \& Longazel, 2010, p. 157).
} 
and county policy outcomes. The basic tenets of social diversity can be summarized in five major propositions.

First, state and county government policy is determined by competition and cooperation between and among various dominant and minority interests, not just by the dominant group. These nongovernment factions use their resources to influence elected officials.

Second, in the racially stratified United States, there are three main racial/ethnic interest groups: "white" (defined as whites with western and northern European ancestry); "white ethnic" (defined as whites with ancestry traced back to eastern and southern Europe plus Ireland); and "minority" (defined a peoples with ethnic and racial backgrounds among black, Asian, and Hispanic populations). These groups have distinct historical experiences that influence politics and policy choice (Hero, 1998, p.147; 2001, p. 855). From their distinctive historical experiences members gain a common worldview, which dictates how reality is defined and how problems are perceived and resolved.

Third, racial and ethnic populations are not equally distributed across the country, and stratification configurations (dominant-minority) differ as well. The social diversity patterns of states (and counties) can be broadly delineated into three types according to degree and level of racial and ethnic diversity: homogeneous jurisdictions, populated mainly by whites from Northern and Western Europe (with a very small minority population and relatively few "white ethnics"); bifurcated states/counties, comprised of two major groups — white and minority (and small proportions of white ethnics); and 
heterogeneous environments, characterized by the presence of multiple groups-a relatively large proportion of minorities and white ethnics (and a moderately large white population).

Fourth, differences in social diversity patterns-racial/ethnic compositions and configurations--account for variations in the nature of pluralist politics ${ }^{34}$ and policy outcomes-favorable or unfavorable for minorities. This is because a society's social (diversity) context determines how power is exercised and the way individuals and groups (with different historical experiences) perceive policy issues, especially policies related to minorities.

Finally, given that social diversity patterns are not fixed, changes in the ethnoracial composition and configuration of a political jurisdiction will be reflected in its politics, policy outputs and voting patterns.

To examine the usefulness of his model, Hero assesses the degree to which social diversity, and various other factors commonly used in state politics research, are associated with state policy choices. His conclusion, drawn from comparative data across fifty U.S. states, is based on a quantitative analysis of policies central in state politics, including education, health, and criminal justice. Overall, he finds social diversity more significant than other alternatives considered, including socioeconomics, in explaining state-level variations in social policy outcomes. ${ }^{35}$

\footnotetext{
${ }^{34}$ Hero (1998) identifies three types of political pluralism associated with different social diversity patterns: consensual pluralism in homogeneous settings, competitive pluralism in heterogeneous places, and limited or hierarchical political pluralism in bifurcated states and counties.

${ }^{35}$ The other explanatory factors examined were: political culture, ideology, party competition, legislator professionalism and gubernatorial power.
} 
Hero extends his model to another level, examining social diversity and public policy at the local level. His analysis of two "illegal" immigration policies adopted through the initiative process--English Only (adopted by voters in California, Colorado and Florida in 1986) and Proposition 187 (adopted by Californians in 1994)--suggests within state variations in the vote for these policies was a product of different social diversity patterns within and across counties. He finds counties with higher minority populations were less supportive of the ballot measures than counties with smaller minority populations. In particular, homogeneous counties showed the strongest support for Official English and Proposition 187. Bifurcated counties also supported the measures, largely due to white voters; most Latinos voted against it. The strongest opposition to Official English and Proposition 187 was in heterogeneous counties.

These findings are consistent with and supportive of his research on state public policy, where heterogeneous environments are associated with neutral, if not positive, policy outcomes for minorities. While the evidence suggests homogeneous context (even in progressive states), and the presence of a large minority populations (bifurcation), was associated with the worse policy outcomes for minorities (Hero \& Tolbert, 1996).

Hero (1998) suggests that the "racial threat" hypothesis (that white racism increases with competition posed by a greater proportion of African Americans in a community) explains the Anglo response to Latino immigrants, which consists of instituting legal controls and other measures to stymie a perceived threat to their dominant status. The concept, based on Hubert Blalock's (1967) power-threat thesis, has 
not been widely applied to Hispanics, but recent scholarship indicates that demographics altering existing majority-minority relations make it relevant (Rigby, Bruch \& Soss, 2007; Markert, 2010).

Theories of cultural differentiation support Hero's conclusions that negative reactions to diversity can occur when a dissimilar group is relatively small, or perceived to be too large. The tipping point thesis argues that when the number of minorities is few, the dominant racial/ethnic group tends to be more receptive to less-alike strangers, or at least begrudging tolerant. When numerical increases in racially/ethnically dissimilar groups reaches the tipping point (as in a bifurcated setting), then hostile responses often occur. ${ }^{36}$ But negative reactions to diversity also occur when the minority group is relatively small, as in the case of homogeneous states and localities. The racial isolation theory specifies that racial isolation encourages negative responses toward minorities (Kinder \& Mendelberg, 1995). From this view, lack of interaction with racially/ethnically different people leads to negative stereotyping of dissimilar groups. Stereotypes contain elements of threat in that they lead to the anticipation of negative events or interactions with "alien" outgroups (Stephan \& Stephan, 1985).

Looking at these prejudice-precipitation variables from a social constructionist perspective leads to the conclusion that a positive or negative response to difference depends on the definition or interpretation of those differences. The social diversity model does not discount this view; rather Hero argues that cultural factors (like worldview of minorities) are shaped by the "racial/ethnic context within which

\footnotetext{
${ }^{36}$ As Luigi Laurenti's classic study on property values and race revealed, the tipping point has no exact number; it is a perceptual stage when the ingroup believes "too many" of "those people" are in its midst and "something needs to be done" (Pardillo, 2005, p. 131).
} 
individuals and groups are situated" (Hero \& Tolbert, 2001, p. 854). That is why he uses categories of social diversity instead of political culture categories like liberal and conservative in his studies.

Hero's (1998) hypothesis leads to three expectations related to municipal action on unauthorized immigration. In homogeneous locations, local government will, under threatening conditions, adopt policies that protect Anglo interests over those of nonwhite foreign in-migrants. ${ }^{37}$ Lack of competitive pluralism allows Anglos, which constitute a numerical majority and enjoy a disproportion share of (wealth, power, and social status) resources, to monopolize decision-making. They can make demands of government over opposition of racial and ethnic groups, native-born and immigrant. Lacking critical mass and resources, minorities will be unable to frustrate the policy objectives of cooperating Anglo groups with undivided interests. If the dominant group does not feel threatened by minority immigrants the probability of a nativist reaction in reduced.

A number of local case studies tend to confirm that negative responses are common in communities experiencing rapid demographic change. High profile cities at the epicenter of the movement against "illegal" immigration are most often studied: Austin, Texas (Skop \& Buentello, 2008); Charlotte, North Carolina (Furuseth \& Smith, 2010); Hazelton, Pennsylvania (Fleury-Steiner, 2010); Santa Ana, California (Harwood \& Myers, 2002); Vista, California (Danielson, 2010). Local governments in these localities passed some of the most punitive immigration control measures in U.S. history. Other municipalities have emulated the controversial measures initiated in these cities.

\footnotetext{
${ }^{37}$ Here the term "Anglo" means all non-Hispanic English-speaking whites, regardless of their religion or ethnicity.
} 
Scholars stress the centrality of rapid demographic change in creating antiimmigrant policy activism in studied areas, while recognizing the economic and political factors shaping shifting settlement patterns. ${ }^{38}$ From this perspective the surge of unauthorized Latino migrants into places with little or no recent experience of large scale settlement (or social diversity) fueled a nativist backlash. When the U.S. Congress failed to pass comprehensive immigration reform in 2006 and again in 2007, restrictionists, making "law and order" claims, pushed the issue of unauthorized immigration to the top of the local political agenda. ${ }^{39}$ Local regulations to deter or deflect undocumented "invaders" were a response to this pressure, which occurred even where immigrants had revitalized neighborhoods and bolstered the local economy (Fleury-Steiner, 2010), and where local elites held immigrant-driven global city aspirations (Provine, 2010). ${ }^{40}$

\footnotetext{
${ }^{38}$ Factors explaining the influx of unauthorized Mexican immigration to U.S. include: (1) industrial restructuring and business and corporate demand for a low-wage, relatively unregulated flexible labor in the U.S. (Cornelius, 1998; Massey, Durand \& Malone, 2002); (2) capitalist penetration into peripheral and premarket societies and bifurcated labor-market in global cities (world system theory); (3) neoliberal structural readjustment policies (that transferred state power upward to global institutions, such as the WTO, and responsibility downward to local communities), economic crisis, and free trade policy, like 1994 NAFTA, that destroyed farming in Latin American encouraging illegal migration (Sassen, 1998); (4) the expansion and militarization of the U.S.-Mexico border, to repress NAFTA-caused migration, and simultaneous decline in the interior enforcement of IRCA (Brownell, 2005); (5) the interests and action/inaction of the U.S. nation-state (e.g., 1986 amnesty laws/failure to reform immigration law in 2006) (Meyers, 2004); (6) chain migration/cumulative causation (Massey, 1990); (7) the cost-benefit decision of individuals and households; (8) immigrant deflection policies initiated by local governments in traditional gateway cities experiencing saturation of immigrant labor niches (Light, 2006); and (9) the economic development decisions of local elites, who recruit businesses that hire unauthorized migrants (FleurySteiner, 2010).

${ }^{39}$ A number of other factors have multiplied the impact of demographic change in new immigrant destinations, including: (1) the devolution of immigration law enforcement authority; (2) the presence of organized anti-illegal immigrant activists; (3) lack of a mature immigrant service and advocacy infrastructure; and (4) an unprepared local government that lacks experience with large scale immigrant settlement and sociocultural diversity.

${ }^{40}$ Local business and corporate elites benefit from immigrant-driven economic development, while average residents are more readily threaten by rapid demographic change (Varsanyi,2010, p. 16).
} 
Public officials in heterogeneous jurisdictions can be expected to protect the rights and preferences of immigrants who become minorities upon entering the United States. ${ }^{41}$ This is because no single group dominates the racial hierarchy and a sizable segment of the population, who can identify with minority immigrants, is willing to use their collective resources to exert influence. At the same time, competitive pluralism prevents any one group from advancing its own interests at the expense of other groups. ${ }^{42}$

Finally, in a bifurcated environment, where political bargaining occurs between two major racial/ethnic interests - nonHispanic white and a single large minority group-policy decisions will be determined by the pressure group with the most influence. Since hierarchical pluralism restricts minority access to decision-making, white interests tend to be more powerful. ${ }^{43}$ Under these conditions, if the demands of Anglos and minority interests clash, politicians will probably be more responsive to the policy preferences of Anglos than to demands made by minorities representing nonwhite immigrants. A minority group can, however, overcome this structural constraint through biracial coalition building. With support from white liberals, a less influential, but cohesive minority coalition can shift the policy direction in favor of minority immigrants. ${ }^{44}$ When

\footnotetext{
${ }^{41}$ In competitive situations native-born racial/ethnic minorities do not always support immigrants. But polling data over the past 50 years indicates that Americans of African, Hispanic, and Asian descent are more accepting of immigration and immigrant-friendly policy than non-Hispanic whites (Smith \& Edmonston, 1997; Hero, 1998; Suro, 2005).

${ }^{42}$ Competitive pluralism can also make cooperation between interests group difficult, especially if interminority competition or conflict exists. A state or locality with a tradition of intergroup coalition building, or government support for that, can, however, overcome this diversity challenge.

${ }_{43}$ See Rodney Hero's (1992) Latinos and the U.S. political system: Two-tiered pluralism.

${ }^{44}$ The presence of a single large minority group facilitates coalition building and collective action, since minorities here possess tighter social networks and are more cohesion than racial/ethnic groups in other types of cities. This, in turn, increases the group's chances of inclusion in a limited pluralist system; a wellorganized group is easier for political leaders to recognize.
} 
immigration and/or race are not politically divisive issues, then the probability of a nativist reaction is also reduced. ${ }^{45}$ In sum, local government can be expected to initiate immigration strategies that reflect and reinforce a city's ethnoracial structure.

\section{Political culture and political leadership}

With race at the core of the analysis, the social diversity thesis sheds light on an oft overlooked dimension of U.S. state and county politics. By identifying the structural factors that shape local political culture, and subsequent worldview about foreigners, the concept overcomes the weaknesses of culture theories. Still, its pluralist interpretation of state and local politics has limitations. Here it is important to highlight the political dimension of voter preferences and political leadership. Social factors have to be activated and expressed by political actors. Results happen because individuals and groups are motivated to intervene in public policy decisions. For this reason, political culture and political initiative need to be a third explanatory dimension.

Drawing on empirical analyses, Wells (2004) stressed the importance of local political culture. She suggests that inclusive policy outcomes are most likely in localities where immigrants are a valued part of the local economy, are well-connected to nativeborn residents and community institutions, and the political culture is liberal and globally focused. $^{46}$

\footnotetext{
${ }^{45}$ There is an incentive for politicians to respond to minority demands, especially where undivided minority interests. But when there are sharp divisions of opinion between dominant Anglos and minorities, politicians will ignore minority voters' interests because it costs them the white swing vote (Brown et al., 2003).

${ }^{46}$ Chernotsky \& Hobbs (2001: 66) identify three categories of cities based their responses to the forces of globalization and the strategies adopted in response to changing global conditions: world cities (metro areas with populations near one million that have a wide array of international interests and contacts and have actively sought to expand their role in the global economy; emerging glocalities (cities with populations of approximately 200,000 to 500,000 that have rapidly moved into the international arena to take advantage of
} 
In the cities she studied - established immigrant gateways ${ }^{47}$ and left-leaning college towns--those factors countered tendencies toward exclusion of undocumented residents during economic downturns, and in places with little ethnic or class diversity. To assess the relative efficacy of different explanations, political scientists S. Karthick Ramakrishnan and Tom Wong (2010) simultaneously test six leading variables, alongside their own hypothesis on political partisanship. Their conclusions, drawn from a universe of twenty thousand U.S. municipalities, is based on quantitative analysis of pro- and antiunauthorized immigrant ordinances enriched with contextual data at the state and local level. According to their analysis, political partisanship is the best predictor of local government policy on unauthorized immigration, with Republican counties (and by extension, cities) pursuing anti-illegal immigration policies at a much higher rate than Democratic areas. Local party composition (a proxy for political ideology and issue preference on immigration) was more statistically significant than the seven other factors assessed: 1) growth of the Latino population; 2) Latino share of population; 3) recency of migration; 4) wage competition; 5) immigration protests; 6) local economic interests; and 7) state-level policy climate toward immigrants.

More research is needed to explore how political purpose is shaped and exercised in particular localities, since, as Ramakrishnan and Wong (2010) point out, it is difficult to ascertain from their research whether the relevancy of partisanship is related to

changes in the global economy); and reactive globalizers (communities with population of 50,000 or less that have been penetrated by the forces of globalization with limited degrees of control over the process). ${ }^{47}$ Established gateways include long-established, continuous immigrant destinations, such as New York and Chicago, and post-World War II gateways, such as Houston and Los Angeles (Singer, 2008). 
"grassroots mobilization from below or to mobilization from above by elected officials and policy entrepreneurs" (p. 90).

Scholars studying multi-jursidictional areas--metro Dallas-Fort Worth (Brettell, 2008), metro Atlanta (Odem, 2008), and metro Washington, DC (Price \& Singer, 2008)-highlight political questions. They suggest that varied reactions to settlement are due to differences in the local tax base and the legal status of immigrants. Anti-immigrant action is rarely aimed at all immigrants; "the exclusive policies are almost exclusively against undocumented Latino immigrants" (Odem, 2008, p. 122).

Political leadership is also highlighted in studies of Rogers, Arkansas (Scheonholtz, 2005), and the Atlanta suburb of Chamblee (Hansen, 2005). ${ }^{48}$ Local governments in these cities adopted measures limiting local involvement in immigration enforcement and made public services more responsive to newcomers regardless of immigration status. To mitigate the negative effects of culture shock, local officials hired cross-cultural liaisons to bridge the gaps separating different groups. They set a positive tone by emphasizing the citywide economic benefits of legal and unauthorized immigrants, and by framing provisions for noncitizens as whole community assets. Basically, political leaders accepted the challenge of nonAnglo immigration-legal and unauthorized, rather than fighting it.

\footnotetext{
${ }^{48}$ Most integration and reception literature focuses primarily on immigrants- their characteristics, settlement patterns, and impact--not on the characteristics of cities and their residents (e.g. see Singer, Hardwick \& Brettell's Twenty-First Century Gateways, 2008). Studies that do account for best community practices tend to concentrate on the role of mediating groups and nonprofit organizations, not local political actors (e.g. see Elżbieta Goździak and Susan Martin's Beyond the Gateway, 2005). Other research on emerging geographies of settlement makes intergroup relations the focal point of inquiry (e.g. see Douglas A. Massey's New Faces in New Places, 2008). This is not public policy analysis.
} 


\section{Study Purpose and Rationale}

Local policy on unauthorized immigration, as an area of study, is underexplored. With that in mind, I began with exploratory policy research. The resulting database verifies and expands existing policy inventories. ${ }^{49}$ It also provided the raw material for developing a typology of U.S. municipal unauthorized immigration policy.

My classification scheme builds on the work of other scholars. I adopt Good's (2005) municipal 'responsiveness' scheme, and Alexander's (2004) 'policy domain' model, after making a few adjustments ${ }^{50}$ Presenting this typology is the first aim of this dissertation.

Offering a theoretical framework to guide comparative research on municipal unauthorized immigration policy is the second goal. Towards this end, I start with Good's (2005) theoretical framework to assess its explanatory usefulness in the United States. Following her lead, I explore aspects of two perspectives--urban regime theory and the social diversity thesis. I then address gaps in these approaches by adding political culture and entrepreneurship as an additional explicit factor. By utilizing in depth case studies, I hope to overcome a weakness in the work of Ramakrishnam and Wong-namely their reliance on political party affiliation as a measure of local political inclinations and likelihood of action on MIP.

\footnotetext{
${ }^{49}$ My sampling frame covers immigrant-specific and general population measures affecting immigrants without legal status.

${ }^{50}$ Good's (2005) model works better for classifying data on unauthorized immigration than Alexander's (2004) policy alternative plan.
} 
Providing a richly detailed contextualized description of municipal response to unauthorized immigration issues in three U.S. cities, and then comparing these, is my final purpose. ${ }^{51}$ Three cases were purposely selected to facilitate cross-city comparison: Sacramento, California; Denver, Colorado; and Portland, Oregon. ${ }^{52}$ Selection was guided by the theoretical propositions of the study. Sacramento is a heterogeneous urban society, Denver a bifurcated municipality, and Portland a mostly nonHispanic white city. The study also employs a "comparable case strategy" (Lijphart, 1975, p. 159), which involves selecting highly similar cases that vary in terms of the policy outputs under investigation. "The logic of the design is that if cases are tightly matched then the variation on the dependent variable can be explained in terms of the remaining differences between the cases" (Good, 2005, p. 4). The cases under investigation are tightly "matched" on a number of factors. Besides their comparable size and common geographic location-the western region of the United States, the municipalities also share like immigration histories. All three of the cases are classified as "reemerging" immigrant gateways. ${ }^{53}$ They experienced high rates of immigration growth in between 1980 and 2000. The cities also have similar socioeconomic profiles, and a tradition of progressive politics. Latinos constitute the largest share of foreign in-migrants in each city, followed by newcomers of Asian descent. Other commonalities: the residents of all three cities are predominantly native-born, and each city has been labeled a "sanctuary city" by anti-immigrant interest

\footnotetext{
${ }^{51}$ We can think of this comparative case approach as intensity sampling, a technique that seeks rich examples of the phenomenon (Patton 1990, p. 171).

${ }^{52}$ In this dissertation, I separate central city from its suburbs and focus only on the former as distinct political units.

${ }_{53}$ Reemerging gateways are largely Western cities that "harbored high foreign-born shares in the early 1900 s, saw them decline through the 1970s, and then grew again in the 1990s" (Singer, 2008, p. 9).
} 
groups and the media. However, recent case studies of immigration for metro Sacramento (Datel \& Dingemans, 2008), and metro Portland (Hardwich \& Meacham, 2008), do not mention municipal immigration policy.

My study covers the twenty-five year period between January 1, 1985 and December 31, 2010. I started in 1985 because the bulk of U.S. cities entered the immigration policy arena then. ${ }^{54}$ The end date coincides with the second wave of local policy activism, which occurred in the aftermath of failed federal immigration reform in 2007. This longitudinal approach lets me track the trajectory of policy processes in case study cities at many points in time. In doing so, it overcomes the temporal problem of most literature on municipal action on unauthorized immigration, which tends to focus on one point in time.

\footnotetext{
${ }^{54}$ Policy phases common in international migration research do not work for organizing data at the local level, because, unlike a national government, municipalities respond to issues at different times.
} 


\section{Research Propositions}

This study explores several propositions relating to the emergence and character of municipal immigration policy, and evaluates their usefulness in understanding policy directions in the three case study cities:

1. Municipal immigration politics and policy choice are shaped by a city's racial/ethnic composition and configuration, which can be broadly delineated into three types according to degree and level of racial and ethnic diversity: homogeneous, heterogeneous, and bifurcated. ${ }^{55}$ Since policymaking occurs within the broader system of racial and ethnic stratification, local governments can be expected to initiate immigration strategies that reflect and reinforce their city's ethnoracial structure. City governments in homogeneous locations will, under threatening conditions, adopt policies that protect Anglo interests over those of nonHispanic white immigrants. If the dominant group does not feel threatened by these newcomers the probability of a nativist reaction is reduced. Public officials in heterogeneous jurisdictions can be expected to take legislative steps to protect the rights and interests of minority immigrants - legal and unauthorized, if the situation warrants it. In a bifurcated environment, policy decisions will be determined by the ethnic/racial group with the most influence. Since racial and ethnic populations are not equally distributed across the United States, and

\footnotetext{
${ }^{55}$ I define homogeneous places as jurisdictions comprised of a dominate Anglo group - which includes all non-Hispanic English-speaking whites, regardless of their religion or ethnicity-- and a very small (less than 40 percent) minority population. Heterogeneous municipalities are characterized by the presence of multiple, more or less equally-sized racial/ethnic groups. Bifurcated cities have a relatively equal-sized Anglo and minority population, but, unlike multiethnic localities, one minority group is significantly larger than the others (Toussaint, 2013).
} 
dominant-minority stratification arrangements vary as well, these different diversity patterns account for city-to-city variation in policy outputs-favorable or nonfavorable for unauthorized minority immigrants. ${ }^{56}$

2. Local government's capacity to act on policy preferences is dependent upon its ability to form an urban regime with immigration purposes. ${ }^{57}$ If local leaders can build a governing coalition to co-produce immigration policy capacity, then that city will have the social production power to take on major immigration initiatives. Without such a regime little or no immigration policy will be produced locally. Since regime development does not occur at the same time across the country (due to variations in urban contexts), differences in regime development patterns - present or not present — explain variation in municipal immigration policy outputs (some or none), and the point in time when immigration policymaking begins.

3. Municipal policy on unauthorized immigration is shaped by local political ideology. There are two main political orientations in the United States-liberal (typically associated with the Democratic Party) and conservative (characteristic of the Republican Party). Liberals believe unauthorized immigrants should have the same rights as U.S. citizens. They expect government to protect the civil liberties and human rights of all people, regardless of nationality or citizenship. Conservatives oppose "sanctuary policies" for unauthorized immigrants. They

\footnotetext{
${ }^{56}$ According to Hero (1998), this is because a society's social (diversity) context determines how power is exercised and the way individuals and groups (with different historical experiences) perceive policy issues, especially policies related to minorities.

${ }^{57}$ The formal structure and rules of city government often makes it difficult for local officials to act.
} 
believe those who break the law by entering the U.S. illegally do not have the same rights as citizens, or immigrants who obey the law by entering legally (“Conservative vs. Liberal,” 2010). Accordingly, local governments in cities with a liberal political culture are more likely to pursue urban citizenship policies ${ }^{58}$ than city officials in places with a more politically conservative outlook, if committed leadership from a "policy entrepreneur" exits. ${ }^{59}$ Without such a change agent, liberal ideals are less likely to be translated into action. Since local political culture and political leadership varies across cities within the same country, these alternative political patterns explain intercity similarities and differences in strategic policy direction.

\footnotetext{
${ }^{58}$ These measures guarantee unauthorized immigrants formal membership in a city's polity, and with that, the civil rights and liberties associated with citizenship (Varsanyi, 2006), including freedom from deportation.

${ }^{59}$ A policy entrepreneur is an individual - in or out of formal government - who exploits an opportunity in order to introduce innovative policy and influence its adoption without regard for the absence of resources required to take on such activity (Mintrom \& Norman, 2009, pp. 652-54; Cohen, 2012, p. 53).
} 


\section{CHAPTER 3}

\section{Research Methods}

Municipal policy on unauthorized immigration, as an area of study, is underexplored. To remedy that, this dissertation raises two questions. First, what unauthorized immigration policies do local governments pursue, under what circumstances, and for what reasons? Second, what explains intercity variation in municipal responsiveness to the policy preferences and interests of residents without legal status? This chapter describes the two approaches used to address those questions: multicity exploratory research, and theory-driven, comparative case study. By combining descriptive and causal methods, I have attempted to provide as complete an approach as possible to the study of municipal responsiveness to unauthorized immigration. The first part of this chapter presents the methodology for the policy exploration chapter. The second section covers the methods used in the case study chapter.

\section{Multicity Policy Exploration}

This section describes typology construction and outlines the steps in the exploratory research process. Primary research was needed because very few secondary sources exist. The resulting inventory of municipal unauthorized immigration policy supplied the raw material for developing a typology about the same. It also provided a context within which to ground my comparative case study. 


\section{Typology construction}

The typology utilized in this study is developed and expanded from two existing typologies-Michael Alexander's (2003) policy domain ordering scheme, and Kristin Good's (2005) municipal responsiveness model.

In Alexander's (2003) classification system, policy domains are components of the political system—socio-economic, legal-political, cultural-religious, and spatial— organized around substantive issues. ${ }^{60}$ His Socio-Economic domain deals with issues related to the labor market and government spending on public housing, health care, education, job and social services. The Legal-Political domain encompasses issues related to civic status and political participation through voting, grassroots mobilization and/or political appointments. In the Spatial domain, policies are associated with concerns about public land use and urban development. Lastly, strategies that focus on the cultural otherness of migrants can be separated into the Cultural-Religious domain.

According to Alexander, this framework is vital in a multi-city comparison. "Since different cities may focus on different areas in their policy response to migrants (or the same city does so in different periods)" (Alexander, 2003, p. 64).

The second ordering scheme - municipal responsiveness — is based on Good's (2005) analyses of multiculturalism policy in seven Canadian cities, and grounded in the principles of democratic governance. ${ }^{61}$ Since the people are the ultimate source of public authority in a democracy, political scientists use the word "responsive" to characterize

\footnotetext{
${ }^{60}$ Alexander's (2003) second classification plan, which focuses on policy alternatives-non-policy, guest worker policy, assimilation policy, and pluralist policy--is based on an analysis of migrant labor policy in Europe and Tel Aviv. It does not work well for classifying policy on unauthorized immigration.

${ }^{61}$ It replaces the policy alternative ordering scheme in Alexander's (2003) model.
} 
various aspects of government performance, that is, the degree to which public officials respond to the issue preferences of citizens. According to Good (2005), in a study of municipal responsiveness to immigrants, questions concerning institutional accessibility and inclusiveness are paramount. Her definition takes this into account. She uses the term "responsiveness" to describe the extent to which public officials adopt policies that respond directly to the needs and issue preferences of immigrants, including decisions about whether (or not) to adjust their services and governance structure to facilitate equitable, inclusive access.

In Good's (2005) framework, policy is classified according to three degrees of municipal responsiveness to immigrants and minorities: responsive, somewhat responsive, and unresponsive. She uses three broad elements of policy to measure the "responsiveness" of municipalities: (1) formal policy, which would include policy proposed or adopted by locally elected or appointed politicians; (2) policy enforcement, which would include policy enforced by local public servants (i.e., employees working for local government departments and agencies such as police, building inspectors, social workers); and (3) informal or de facto polices or practices in all municipal areas. ${ }^{62}$

Good then uses this information to define three degrees of municipal responsiveness to immigrants and minorities: responsive, somewhat responsive, and unresponsive. To evaluate the nature and scope of policy outputs, Good assesses the breadth and depth of policies in place (comprehensive, limited, highly limited), and the policy style of the municipality (proactive, reactive, and inactive/resistant). She

\footnotetext{
${ }^{62}$ De facto policies are programs of action that "in fact" exist but not necessarily by written law or formal operating rules; they are unofficial operating directives communicated off the record or developed by custom and consensus within individual agencies (Toussaint, 2013).
} 
conceptualizes "responsive" municipalities as proactive and comprehensive in their responses to immigrants and ethnic/racial minorities; "somewhat responsive" cities as reactive and their responses limited rather than comprehensive; and "unresponsive" localities as inactive or resistant to multiculturalism policy and their responses to the target population highly limited (Good, 2005, pp. 268-69).

To facilitate the search for policy examples, Good (2005) also developed a list of potential strategies local governments might pursue to achieve their policy objectives. She groups these programs of action into eight general categories: immigrant-welcome city imagery; inclusive political procedures; access and equity in service delivery plans; employment equity initiatives; multiculturalism and anti-racism programs; provision of grants, in-kind contributions and research; support of multicultural festivals; or development of intergovernmental immigration and settlement measures.

Equipped with frameworks to guide me, I plunged into exploratory research. The investigation yielded a list of hotly debated, locally important immigration issues and later, a wide a range policy examples. I modified the starting typology categories based on inductive analysis of this data.

Since none of the issues identified in my study fit into Alexander's (2003) "cultural-religious" domain category, I eliminated that group in my typology. I also added some issues areas specific in unauthorized immigration, like police enforcement of immigration laws, attorney legal opinions and lawsuits to the Legal-Political domain. 
Next, I customized Good's (2005) policy checklist by making the following adjustments. First, I deleted her multicultural festival category. The scope of my research did not include cultural issues. I also removed her multiculturalism and anti-racism program group, as it pertains to local policies designed to meet the equity goals established in the Canadian Multicultural Act (1988) (Good, 2005, p. 284). ${ }^{63}$ This is essentially civil rights legislation (equal opportunity law and affirmative action policy), or corporate diversity management, in the United States. Good (2005) does not distinguish between policies for native-born racial and ethnic groups and first generation foreign in-migrants. In the United States, programs created for racial/ethnic minorities generally are not constructed with the adjustment needs of new foreign-born residents in mind. I make this distinction in my typology, while expanding her categories. I add eighteen new policy examples, and a description of what each plan of action might look in practice and pertain to the issue of unauthorized immigration; none of Good's (2005) policy types address the issue of illegal status. To facilitate organization, I also frame these strategies as areas of municipal authority (see Appendix A).

\footnotetext{
${ }^{63}$ The goals of the Act include a federal government commitment to: remove barriers to equitable participation in all aspects of Canadian society (3.1a); encourage (social, cultural, economic and political) institutions to be inclusive of ethno-cultural diversity (3.1f); preserve and enhance the use of languages other than English and French (3.1i); ensure that all Canadians have equal access to employment regardless of their ethnic origins 93.2a); and, more generally, to be "responsive" to Canada's ethno-cultural diversity (3.2f). The scope of its mandate extends beyond public institutions to include the business community, voluntary and other private sector organizations (5.1d). [1988, c. 31, assented to July 21, 1988].
} 
Finally, some of the criteria Good (2005) uses to evaluate policy outputs are problematic. Her "inactive/resistant" policy style category is not mutually exclusive. And she fails to operationalize indicators of policy "breadth and depth." I use "policy impact" in place of these measures.

\section{The exploratory research process}

This section describes how I searched various data bases, collated, and categorized the data drawn from exploratory research. In the first phase of research, I used Google to scan the Web for national-level organizations with a stake in local immigration. My sources were derived from a word text search of U.S. municipal leader associations (e.g., United States Conference of Mayors, National League of Cities); research policy institutes (e.g., Brookings Institute, Immigration Policy Center, Center for Immigration Studies, Migration Policy Institute); national immigrants' rights organizations (e.g., ACLU, Bill of Rights Defense Committee, National Council of La Raza, National Employment Law Project); national anti-immigrant organizations (e.g., Federation for American Immigration Reform, NumbersUSA, Team America PAC); and immigration law centers (e.g., American Immigration Law Foundation, National Immigration Law Center). I found no municipal immigration policy tracking organization, although a few organizations do track policy related to particular themes. The Bill of Rights Defense Committee, for instance, produced a downloadable booklet of anti-Patriot Act resolutions passed by state, county, and local governments. Most of the sampled websites had an "Issue" option on their main menu. Otherwise, I found relevant information on the dropdown menu when I clicked on "Publications" or "What We Do." 
I inventoried the content of those web pages looking for and recording (on an Excel spreadsheet) data about local immigration debates, and municipal responses to those issues. I also examined documents (research reports, working papers, policy and legal briefs, factsheets, newsletters and press releases) that were published by these organizations and posted on their websites.

From this research, I developed a checklist of the issues most hotly debated in U.S. cities over the past twenty five years. The issues selected were those most frequently raised by people with a role in municipal agenda setting — local officials, news reporters, and claimsmakers on both sides of the immigration debate. I also constructed a list of local policy responses to the issues on the first checklist. I used these checklists to guide the second phase of my research.

To facilitate analysis, I constructed a two-dimensional matrix comprised of examples of immigration policy produced in selected U.S. cities. Data in my policy inventory was sorted into mutually exclusive rows and columns based on study headings - policies and cities respectively. ${ }^{64}$ The policy section was further broken down by issue area. The resulting grid provided the raw material to develop a typology for comparing cities' responses to a common set of issues related to unauthorized immigration. The organizing scheme helped squeeze some order out of a chaotic set of information.

When the two ordering schemes described above are combined, the result is a classification system of municipal responsiveness to unauthorized immigration by policy domain and issue area (see Appendix B). In the typology, the columns represent the

\footnotetext{
${ }^{64}$ I used my brain to construct the typologies, not a computer program.
} 
policy responses, and the rows represent municipal domains subdivided into policy areas that address specific issues. The matrix cells can be filled with adopted or proposed policies, each cell representing how a specific policy type (say, unresponsive) is expressed in a particular policy area (say, day labor solicitation). The contents of the cells were derived from a mix of inductive and deductive reasoning. Most are based on actual policies gleaned from my exploratory policy research, or found in literature, then classified according to the scheme. A few policies were inferred from gaps in typology as "potential policies" that may or may not actually exist.

The content presented is not an accurate representative of policymaking in any city, but rather an analytic framework that can be applied to particular cities and policies to better understand them. As is the case with any classification system, this model has limitations. The two policy types proposed here are ideal types. No city will likely conform to one type across all policy domains all the time, a mix of unresponsive and responsive policies are probable. Also, policy trajectory is not fixed. Policy development does not always evolve from anti-immigrant to pro-immigrant. A city that produced foreign-born friendly policy in one era may not craft that same kind of policy always. Still, the framework may indicate which domains or policy areas tend to dominate local policymaking in a given period. ${ }^{65}$ Identifying a prevailing policy pattern is possible in most cases.

\footnotetext{
${ }^{65}$ If the date that a policy was adopted is included in the cell, then the model can also be used to track activity overtime.
} 


\section{Case Study Methods}

The current lack of academic research into municipal policy on unauthorized immigrants, and the consequent dearth of theory about it, led to my decision to adopt the case study approach. Case studies play an important role in advancing a field's knowledge by providing more detailed information than what is available through other methods. Case studies also allow one to present data collected from multiple methods to provide a complete story. This is something which cannot appear in a policy matrix. It is also an important mechanism for theoretical generalization. By combining descriptive and casual methods, I have attempted to provide as complete an approach as possible to the study of municipal responsiveness to unauthorized immigration. This section starts with a description of the model that I used to evaluate policy, followed by details of the methodology.

\section{Typology construction}

To evaluate the nature and scope of policy outputs, I developed a second typology. It uses two criteria to assess local government responsiveness to unauthorized immigrants: policy style and policy impact. The first indicator, policy style, is measured in terms of three problem-solving approaches: proactive, reactive, and defensive. Each type indicates the amount of effort city officials put into policymaking. A proactive approach is well-planned and anticipatory; it requires institutional effort to identity and address the needs of unauthorized immigrants before problems arise. Reactive policymaking entails setting up a unit of city government (police liaison, task force, or advisory committee) to respond ad hoc to community demands and complaints that 
cannot be ignored. This is a passive method. The third category, defensive, involves denying, trivializing, or deliberately refusing to acknowledge the unique needs and concerns of residents without legal status. These types are based on a model by Marcia Wallace and Frances Frisken (2000). ${ }^{66}$ Who derived their categories from comparative study of public service agency response to immigrant settlement in seven municipalities in the Greater Toronto Area.

My second assessment standard is policy impact. This outcome-based performance indicator, commonly used in public policy research, measures the effect of policies in terms of these values: positive, moderately beneficial, and negative. A positive policy result increases access to opportunities for unauthorized foreign-born residents in most all aspects of mainstream urban life. If these programs of action were not initiated the well-being of immigrants without legal status would be markedly diminished. Moderately beneficial policies increase access to opportunities for undocumented residents in some aspects of mainstream urban life. If these programs of action were not initiated the well-being of this population would be diminished somewhat. A negative policy does not increase access to opportunities for unauthorized immigrants or improve their quality of life. These programs of action either make no real difference or cause harm. Evidence of "benefit" is demonstrated by the breadth and depth of policies in and across municipal policy domains. Table 1 summarizes my evaluation criterion and scoring system.

\footnotetext{
${ }^{66}$ I replaced Wallace \& Frisken's (2000) "inactive" category label with "defensive."
} 
Table 1 Policy evaluation criteria and score

\begin{tabular}{lll}
\hline Policy Evaluation Criteria & & Score \\
\hline Policy style & & \\
\hline Proactive & $\mathrm{H}$ & 3 \\
Reactive & $\mathrm{M}$ & 2 \\
Defensive & $\mathrm{L}$ & 1 \\
Policy impact & & \\
\multicolumn{1}{c}{ Positive } & $\mathrm{H}$ & 3 \\
Moderately beneficial & $\mathrm{M}$ & 2 \\
Negative & $\mathrm{L}$ & 1 \\
\hline
\end{tabular}

The dependent variable in this study--local government policy--is classified according to three degrees of municipal responsiveness to unauthorized immigrants: responsive, somewhat responsive, and unresponsive. "Responsive" policies are proactive and produce a positive outcome for unauthorized immigrants. "Somewhat responsive" policies are reactive and only moderately beneficial to city residents without legal status. An "unresponsive" policy generates negative consequences for authorized foreign nationals, and stems from a defensive approach to policymaking. The policy "scores" that result are heuristic guides rather than scaled measures.

As Table 2 shows, my conceptualization of municipal responsiveness is a continuum representing a range of policy alternatives. These are ideal types. A "real" city might initiate some policies proactively while ignoring or responding reactively to other unauthorized immigration issues. 
Table 2 A typology of municipal responsiveness to unauthorized immigrants

1--------------------------------2-----------------------------------3

$-3$

Responsive Somewhat responsive Unresponsive

$\begin{array}{llll}\text { Policy style } & \text { Proactive } & \text { Reactive } & \text { Defensive }\end{array}$

Policy impact Positive Moderately beneficial Negative

The case study research process

This section lays out my case selection criteria, time frame, strategies for collecting and analyzing data.

Three cases were purposely selected to facilitate cross-city comparison:

Sacramento, California; Denver, Colorado; and Portland, Oregon. Selection was guided by the theoretical propositions of the study. Sacramento is a heterogeneous urban society, Denver a bifurcated municipality, and Portland a mostly nonHispanic white city. The study also employs a "comparable case strategy" (Lijphart, 1975, p. 159), which involves selecting highly similar cases that vary in terms of the policy outputs under investigation. "The logic of the design is that if cases are tightly matched then the variation on the dependent variable can be explained in terms of the remaining differences between the cases" (Good, 2005, p. 4). As Table 3 and Table 4 illustrates, the cases under investigation are tightly "matched" on a number of factors. Besides their comparable size and common geographic location - the western region of the United States, the municipalities also share like immigration histories. All three of the cases are classified as "reemerging" immigrant gateways. ${ }^{67}$ The cities also have similar socioeconomic profiles,

${ }^{67}$ Reemerging gateways are largely Western cities that "harbored high foreign-born shares in the early 1900s, saw them decline through the 1970s, and then grew again in the 1990s" (Singer, 2004, p. 7). 
and a tradition of progressive politics. Latinos constitute the largest share of foreign inmigrants in each city, followed by newcomers of Asian descent. Other commonalities: the residents of all three cities are predominantly native-born, and each has been labeled a "sanctuary city" by anti-immigrant interest groups and the media.

Table 3 Comparison of case city general population characteristics, and changes 1990-2010

\begin{tabular}{llllcc}
\hline Place & $\begin{array}{l}2010 \text { Census } \\
\text { Numbers }\end{array}$ & $\begin{array}{l}2000 \text { Census } \\
\text { Numbers }\end{array}$ & $\begin{array}{l}\text { 1990 Census } \\
\text { Numbers }\end{array}$ & $\begin{array}{l}\text { 1990-2000 } \\
(\%) \pm \text { change }\end{array}$ & $\begin{array}{l}2000-2010 \\
(\%) \pm \text { change }\end{array}$ \\
\cline { 2 - 6 } Denver, $C O$ & 600,158 & 554,636 & 467,610 & 18.6 & 8.2 \\
Portland, OR & 583,776 & 529,121 & 437,319 & 21.0 & 10.3 \\
Sacramento, $C A$ & 466,488 & 407,018 & 369,365 & 10.2 & 14.6 \\
\hline
\end{tabular}

Table 4 Comparison of case city foreign born population characteristics, and changes 1990-2010

\begin{tabular}{|c|c|c|c|c|c|}
\hline Place & $\begin{array}{l}2010 \text { Census } \\
\text { Numbers } \%\end{array}$ & $\begin{array}{l}2000 \text { Census } \\
\text { Numbers \% }\end{array}$ & $\begin{array}{l}1990 \text { Census } \\
\text { Numbers \% }\end{array}$ & $\begin{array}{l}1990-2000 \\
(\%) \pm \text { change }\end{array}$ & $\begin{array}{l}2000-2010 \\
(\%) \pm \text { change }\end{array}$ \\
\hline \multirow{3}{*}{$\begin{array}{l}\text { Sacramento, CA } \\
\text { Portland, OR } \\
\text { Sacramento, CA }\end{array}$} & $96,924 \quad 16.4$ & 96,601 & 43,715 & 120.9 & 0.3 \\
\hline & $\begin{array}{ll}78,892 & 13.7\end{array}$ & 68,976 & 33,601 & 105.3 & 14.3 \\
\hline & $103,152 \quad 22.3$ & 82,616 & $\begin{array}{ll}50,569 & 13.7\end{array}$ & 63.4 & 24.8 \\
\hline
\end{tabular}


Table 5 Comparison of case city population characteristics by race and ethnicity, 1990-2010

\begin{tabular}{|c|c|c|c|c|c|c|}
\hline Place & $\begin{array}{l}2010 \text { Census } \\
\text { Numbers }\end{array}$ & $\%$ & $\begin{array}{l}2000 \text { Census } \\
\text { Numbers }\end{array}$ & $\%$ & $\begin{array}{l}1990 \text { Census } \\
\text { Numbers }\end{array}$ & $\%$ \\
\hline $\begin{array}{l}\text { Denver, } C O \\
\text { American Indian and Alaska Native }\end{array}$ & 20,433 & 1.4 & 12,187 & 2.2 & 5,381 & 1.2 \\
\hline Asian and Pacific Islanders & 21,040 & 3.5 & 20,365 & 3.6 & 11,005 & 2.4 \\
\hline Black or African American & 61,435 & 10.2 & 67,375 & 12.1 & 60,046 & 12.8 \\
\hline Hispanic or Latino & 190,965 & 31.8 & 175,704 & 31.7 & 107,382 & 23.0 \\
\hline Non-Hispanic White & 313,012 & 52.2 & 287,997 & 51.9 & 287,162 & 61.4 \\
\hline Portland, OR & & & & & & \\
\hline American Indian and Alaska Native & 5,991 & 1.0 & 12.125 & 2.3 & 5,399 & 1.2 \\
\hline Asian and Pacific Islanders & 44,801 & 7.6 & 43,143 & 6.7 & 23,185 & 5.3 \\
\hline Black or African American & 36,695 & 6.3 & 41,589 & 7.9 & 33,530 & 7.7 \\
\hline Hispanic or Latino & 54,840 & 9.4 & 36,058 & 6.8 & 13,874 & 3.2 \\
\hline Non-Hispanic White & 421,773 & 72.2 & 399,351 & 75.5 & 362,503 & 82.9 \\
\hline Sacramento, $C A$ & & & & & & \\
\hline American Indian and Alaska Native & 5,291 & 1.1 & 11,303 & 2.8 & 4,561 & 1.2 \\
\hline Asian and Pacific Islanders & 92,158 & 19.7 & 83,841 & 20.6 & 55,426 & 15.0 \\
\hline Black or African American & 68,335 & 14.6 & 70,218 & 17.3 & 56,521 & 15.3 \\
\hline Hispanic or Latino & 125,276 & 26.9 & 87,974 & 21.6 & 60,007 & 16.2 \\
\hline Non-Hispanic White & 161,062 & 34.5 & 164,974 & 40.5 & 197,157 & 53.4 \\
\hline
\end{tabular}

Table 6 Comparison of changes in case city race and ethnic populations, 1990-2010

\begin{tabular}{|c|c|c|c|}
\hline & Denver & Portland & Sacramento \\
\hline \multicolumn{4}{|c|}{ American Indian and Alaska Native } \\
\hline $1990-2000,(\%) \pm$ change & 126.5 & 124.5 & 147.8 \\
\hline $2000-2010,(\%) \pm$ change & 67.7 & 50.6 & -53.2 \\
\hline \multicolumn{3}{|l|}{ Asian and Pacific Islanders } & 51.2 \\
\hline $2000-2010,(\%) \pm$ change & 3.3 & 3.8 & 9.9 \\
\hline \multicolumn{4}{|l|}{ Black or African American } \\
\hline $1990-2000,(\%) \pm$ change & -88 & -117 & -27 \\
\hline $2000-2010,(\%) \pm$ change & & & \\
\hline \multicolumn{4}{|l|}{ Hispanic or Latino } \\
\hline $1990-2000,(\%) \pm$ change & $\begin{array}{r}03.0 \\
87\end{array}$ & $\begin{array}{r}159.9 \\
520\end{array}$ & 46.6 \\
\hline $2000-2010,(\%) \pm$ change & & & \\
\hline \multicolumn{4}{|l|}{ Non-Hispanic White } \\
\hline $1990-2000,(\%) \pm$ change & 87 & 56 & 24 \\
\hline $2000-2010,(\%) \pm$ change & & 0.0 & \\
\hline
\end{tabular}


Table 7 Comparison of case city socioeconomic characteristics, 1990-2010

\begin{tabular}{llll}
\hline & Denver & Portland & Sacramento \\
\hline Per capita money income (\$) & & & \\
1990 & 15,590 & 14,454 & 14,087 \\
2000 & 24,101 & 22,643 & 18,721 \\
2010 & 32,051 & 30,631 & 25,744 \\
Median household income (\$) & & \\
1990 & 25,106 & 25,587 & 28,183 \\
2000 & 39,500 & 40,146 & 37,049 \\
2010 & 47,499 & 50,177 & 50,781 \\
Persons below poverty line, individuals (\%) & & & \\
1990 & 17.1 & 14.5 & 17.2 \\
2000 & 14.3 & 13.1 & 20.0 \\
2010 & 18.8 & 16.8 & 18.6 \\
Media value owner-occupied units (\$) & & & \\
1990 & 79,168 & & \\
2000 & 165,800 & 154,900 & 128.800 \\
2010 & 243,400 & 292,800 & 275,800 \\
Bachelor's degree or higher, persons age 25+(\%) & & & \\
1990 & 29.0 & 27.1 & 23.5 \\
2000 & 34.5 & 32.7 & 23.9 \\
2010 & 41.3 & 42.0 & 29.2 \\
\hline
\end{tabular}

Table 8 Comparison of case city geographic and political characteristics

\begin{tabular}{llll}
\hline & Denver & Portland & Sacramento \\
\hline $\begin{array}{l}\text { U.S. region } \\
\begin{array}{l}\text { Type of immigration } \\
\text { destination }\end{array}\end{array}$ & $\begin{array}{l}\text { western } \\
\text { re-emerging }\end{array}$ & $\begin{array}{l}\text { Western } \\
\text { re-emerging }\end{array}$ & $\begin{array}{l}\text { Western } \\
\text { re-emerging }\end{array}$ \\
$\begin{array}{l}\text { Political culture and rank* } \\
\text { Political structure }\end{array}$ & $\begin{array}{l}\text { Liberal 47th } \\
\text { Unreformed } \\
\text { (strong mayor/ council) }\end{array}$ & $\begin{array}{l}\text { Liberal 27th } \\
\text { Reform-style } \\
\text { (commission) }\end{array}$ & $\begin{array}{l}\text { Liberal 69th } \\
\text { Unreformed } \\
\text { (mayor-council) }\end{array}$ \\
\hline
\end{tabular}

* Liberal-Conservative rankings based on the voting returns of the 2004 presidential election (BACVR).

My study covers the twenty-five year period between January 1, 1985 and

December 31, 2010. I started in 1985 because the bulk of U.S. cities entered the immigration policy arena then. ${ }^{68}$ The end date coincides with the second wave of local policy activism, which occurred in the aftermath of failed federal immigration reform in

${ }^{68}$ Policy phases common in international migration research do not work for organizing data at the local level, because, unlike a national government, municipalities respond to issues at different times. 
2007. This longitudinal approach lets me track the trajectory of policy processes in case study cities at many points in time. In doing so, it overcomes the temporal problem of most literature on municipal action on unauthorized immigration, which tends to focus on one point in time.

Studying policy activity in the three case cities involved generating three different but overlapping data sets, each of which was associated with a different methodology. At the city level of analysis, data were collected on municipal action on unauthorized immigration in three cities, as well as the cities themselves, through structured content analysis of relevant articles in seven local daily newspapers, and four national papers, during a twenty-five year period. At the municipal level, data on locally generated unauthorized immigration policy were gathered from government archives in the three case cities during the same time period. At the nongovernment organizational level, data were gleaned from secondary analysis of accounts written and published by agencies on both sides of the "illegal" immigration debate about municipal responsiveness. Contacts with local officials and community leaders were used to fill-in gaps in the data or clarify a conflicting account.

My initial source of data came from a word text search of newspapers and news blogs published between January 1, 1985 and December 31, 2010 in my three case cities. These news sources included: the Oregonian, Willamette Week, Portland Tribune, and Portland Business Journal in Portland; the Denver Post, Rocky Mountain News, and Denver Business Journal in Denver; and the Sacramento Bee, Sacramento Observer, and Sacramento Business Journal in Sacramento. I also collected articles, about immigration 
politics in the three cities, from the archives of some of the largest metropolitan newspapers (Los Angeles Times, New York Times, and Washington Post) and a few national sources (USA Today and Associated Press). I relied on two computer assisted research services-NewsLibrary.com and (the newspaper database in) LexisNexis--to help me locate city-specific information published in these sources. To narrow the search, I relied on the same Index Terms strategy used during my policy survey research. I also pulled data from the web pages of local immigrants' rights organizations, and their counterparts—anti-immigrant groups. I read relevant city-specific reports and press releases available on their websites. To guide data collection, I used the issue-policy checklist developed from my exploratory policy research. The document data described above was used to make inferences about circumstances surrounding local immigration policymaking. I also gained archival research leads.

Archival data was my primary data source, and included the examination of these items: executive orders and administrative laws; council bills; resolutions and proclamations issued by elected officials and various government departments and agencies; municipal codes and ordinances; police department manuals; legal opinions; memorandums; agenda packages, meeting materials and meeting minutes; permits; budget documents; press releases and letters. I got most of these records from online records libraries accessible via the web page of the City Auditor or City Clerk.

I occasionally used focused questions to corroborate evidence obtained from other sources, or to fill-in gaps in my research. Respondents were interviewed for a short period of time and asked to answer specific questions. The conversations took place over 
the telephone or by email. The people contacted were government officials, or persons mentioned in a newspaper article or on a website.

The aim of the second phase of my research was to refine and build on the lists constructed during the first phase. In phase one I identified general policy categories. In phase two I was looking for articles about what was happening in the specific case cities. I used of two computer assisted research services-NewsLibrary.com and (the newspaper database in) LexisNexis--to find stories published in national and local newspapers about municipal immigration policy. To focus the search, I used a list of key words derived from my earlier research. For instance, to find articles pertaining to the day labor issue, I typed the word "day laborer" into the news bank search engine. I applied the advance search option to limit the scan to my study dates_January 1, 1985 to December 31, 2010. To exclude stories that focused on national instead of local immigration actions, I typed a series of key Index Terms separated by the word 'AND' into the search engine. For example: local ‘AND’ immigrant 'AND' sanctuary; or police ‘AND' immigration 'AND' enforcement. I saved relevant articles in a file folder on my computer and later, analyzed and cataloged their contents. Data gleaned from these articles was summarized and entered into an Excel spreadsheet, which I stored in a folder on my computer. ${ }^{69}$ To this database, I added information derived from the few empirical studies that exist. ${ }^{70}$

\footnotetext{
${ }^{69}$ Data sources were recorded and stored on the same spreadsheet. These could be cross-referenced with the corresponding bibliography document that I created.

${ }^{70}$ Hobbs (1994); Wells (2002); Light (2006); and Varsanyi's (2010) anthology on local immigration policymaking in the United States.
} 
Still, it should be emphasized that this is a partial list, due to the patchiness of secondary data and limited availability of finding primary sources. As a result, I adapted my research to fit the most readily accessible data sources, rather than the totality of the policy pool. As previously discussed, this imperfect policy subset consists of municipal response to seven hotly debated, locally important immigration issues.

\section{Comparative analysis}

To reduce and systematically analyze descriptive data, I used my typology tool. Pattern-matching was my analytic strategy. A description of the process follows.

First, I sorted evidence from my three case cities into appropriate policy domain and issue area categories, according to the classification scheme. After filling the matrix with available data, I then compared each city's empirical policy pattern with the responsiveness evaluation criterion presented earlier. These evaluation measures were constructed to facilitate systematic assessment of a city's level of responsiveness to foreign in-migrants. I assigned each city a score based a match between its prevailing policy pattern and the designated indicators of responsiveness. A city with a high score would be judged "responsive." Those with medium and low scores would be deemed "somewhat responsive" and "unresponsive" respectively.

\section{Theoretical evaluation}

Finally, I evaluated the cases in relation to the three explanatory frameworks presented below. A summary and discussion of these findings is reported in Chapter 6 .

(1) According to regime theory, different sets of interests come together as a regime around a particular set of goals. The interests that might be expected to 
come together to constitute a pro-immigrant regime might include: immigrants' rights advocates, ethnic minority groups, labor unions, community-based nonprofits, local media, business associations, commercial property owners, immigration lawyers, civil liberty and civil rights organizations, faith-based networks and groups (e.g., the Sanctuary Movement), elected and appointed officials from the City and County (including police and sheriffs), police watch dog groups, foreign consulates, immigrant and refugee resettlement organizations, state congressional members, and the immigrants themselves. Anti-illegal immigrant regimes might include: immigrant-restriction organizations and "think tanks," local media, business associations, neighborhood associations, elected and appointed officials from the City and County (including police and sheriffs), state congressional members, federal immigration personnel, citizen militia members and white supremacists. I noted when and where these interests were present in the three cities studied.

(2) In the second phase of pattern-matching, I compared the response patterns of local government with the theoretical propositions of the social diversity thesis. I noted where the data was consistent with the frameworks and where it was not.

(3) Finally, I assess how political culture as expressed through entrepreneurial political leaders has shaped local policy decisions on unauthorized immigration. 


\section{CHAPTER 4}

The Range of Municipal Unauthorized Immigration Policy: A Multicity Exploration

This chapter draws on a larger universe of cities to illustrate U.S. trends in municipal unauthorized immigration policy. It presents findings from my exploratory research on locally important immigration debates, and municipal responses to those issues. This data provided the raw material to develop a classification scheme for comparing the policy reactions of different cities within one or several policy areas, or to follow one city's policy responses over time. I begin with a summary of the most hotly contested immigration issues arising in U.S. cities over the past two decades. Then, I present the typology and present some notable highlights.

\section{Issue Briefs}

Seven locally important immigration debates can be inferred from the sources surveyed. All are related to the theme of unauthorized immigration. This section outlines these controversies, which began showing up on local political agendas in the mid-1980s and center on these hot-button issues: 1) asylum for unauthorized refugees; 2) amnesty for "illegal" immigrants; 3) worksite deportation raids; 4) devolution of immigration law enforcement; 5) government benefits for noncitizens; 6) day labor-contractor market exchanges; and 7) "locally legal" identification cards. The issue briefs that follow provide a snap shot of each problem, and lay out the debates surrounding the issues. 


\section{Asylum for unauthorized refugees}

There are no federal laws governing who can move into a city. During the 1980s thousands of unauthorized Salvadorans, Guatemalans, and Nicaraguans entered the United States to escape persecution in their homelands. When they were denied asylum due to Cold War politics, local government entered the debate over who should be allowed into the United States and who should decide this. That was in 1980, the year the U.S. Congress passed the Refugee Act. The law was intended to expand eligibility for political asylum in the United States. ${ }^{71}$ That same year, Ronald Reagan was elected president of the United States. The new administration's handling of both the overseas refugee admissions program, and the new asylum system, became the subject of intense criticism from the growing human rights community. At the time, refugees from communist countries in Southeast Asia and the Eastern Europe were given preferential admittance to the United States, while Guatemalan and Salvadoran applications for political asylum were being rejected. ${ }^{72}$ This uneven practice, which linked the fate of asylum seekers to Cold War foreign concerns rather than the humanitarian standard of the new Refugee Act, set the stage for a decade-long battle that eventually involved City Hall.

\footnotetext{
${ }^{71}$ The Refugee Act of 1980 broadened the Cold War definition of a refugee, which was a person fleeing communism or coming from the Middle East, to make it consistent with the non-ideological humanitarian protocol established by the United Nations in 1967. To be granted asylum under the new act, a refugee or asylee must demonstrate "well-founded fear of being persecuted." It also created a new legal category of refugee, an "asylee." Unlike a refugee, who attempts to gain admission into the United States from outside the country, an asylee applies for refugee status after arriving on U.S. soil.

${ }^{72}$ Haitian applications for political asylum were also rejected, likely because of poverty and race (Maharidge, 1985; Rother, 1986; Wilson 1986; Sanders, 1987a; Meyers, 2004).
} 
On one side of the controversy were sanctuary movement supporters--immigrants' rights lawyers, religious activists, and the refugees themselves. ${ }^{73}$ On the other side were President Reagan and his administration, the State Department, and the Department of Justice (including the INS and FBI). The first group accused the federal government of violating the human rights of Central American asylum seekers. ${ }^{74}$ The United States, they argued, had ignored political oppression in El Salvador and Guatemala because it would embarrass the administration to admit that U.S. allies were persecuting their citizens. The Reagan administration, which considered Central Americans economic refugees, denied this. ${ }^{75}$ Salvadoran and Guatemalan asylees in-country where often deported. In some high profile cases, the religious activists who brought them in were indicted on alien smuggling charges.

Frustrated with limited influence at the national level, the sanctuary movement transferred its policy reform efforts to the municipal level. This coalition of religious groups launched a "City of Refuge" campaign to persuade local governments to offer their jurisdictions as a sanctuary for asylum-seekers discriminated against by federal authorities. Most cities did nothing. Some took up the humanitarian cause. In doing so, they ignited a still unresolved controversy about the role of local government in immigration affairs. In the meantime, many of the Central Americans who sought asylum in the United States during the 1980s remained here.

\footnotetext{
${ }^{73}$ For a historical account of the sanctuary movement, see Maharidge, 1985; Sander, 1987a; Lynd \& Lynd, 2002; Walsh, 2005; Chuang \& Haught, 2007).

${ }^{74}$ Article 14 of the Universal Declaration of Human Rights recognizes asylum as a universal human right. ${ }^{75}$ U.S. aid to El Salvador and Guatemala was the primary reason given for denying Central Americans admittance into the United States.
} 


\section{Amnesty for unauthorized immigrants}

In 1986, Congress passed the Immigration Reform and Control Act (IRCA) granting approximately 2.8 million undocumented immigrants legal status in the United States. They received a Green Card, which could lead to U.S. citizenship. Immediate relatives or dependents, which included about 143,000 individuals, could also qualify for the resident identity card and work permit. Before the 1986 legislation, amnesty in the United States was only granted on a limited, case by case basis (U.S. Immigration Support, n.d.). Six additional mass amnesties have occurred since. ${ }^{76}$

The Comprehensive Immigration Reform Act of 2007 was an attempt to enact an eighth amnesty for immigrants. ${ }^{77}$ The bill, which was also proposed in the previous session of Congress, never became law. It would have provided legal status and a path to citizenship for about 12 to 20 million unauthorized immigrants, while tightening border enforcement. The proposed legislation was a counter measure to the Border Protection, Anti-terrorism, and Illegal Immigration Control Act of 2005 (H. R. 4437). That piece of legislation, also known as the "Sensenbrenner Bill," for its sponsor in the House of Representatives, Wisconsin Republican Jim Sensenbrenner, has been called the "toughest anti-amnesty, enforcement-only immigration bill in history" (How Democracy Works,

\footnotetext{
${ }^{76}$ INS § 245(i) Amnesty, 1994 (a temporary rolling amnesty for 578,000 illegal aliens; INS § 245(i) Amnesty, 1997 (an extension of the 1994 amnesty); Nicaraguan Adjustment and Central American Relief Act Amnesty, 1997; Haitian Refugee Immigration Fairness Act Amnesty, 1998; Late Amnesty, 2000 (an amnesty for those who claim they should have been amnestied under IRCA); Life Act Amnesty, 2000 (a reinstatement of the rolling Section 245(i) amnesty).

${ }^{77}$ Its full name is Secure Borders, Economic Opportunity and Immigration Reform Act of 2007 (S. 1348).
} 
2010). ${ }^{78}$ It called for making illegal immigration a felony offense punishable by at least a year in jail.

The bill did not pass the Senate, but it was the catalyst for the 2006 U.S. immigration reform protests involving millions of people across the United States. The march was followed by one-day boycott on May $1^{\text {st }}$ dubbed A Day without an Immigrant, in reference to a popular political satire film. ${ }^{79}$ To raise awareness about the importance of "illegal" immigrants to the U.S. economy, supporters abstained from buying, selling, working, and attending school. They rallied in major cities across the country to demand a general amnesty and fewer Immigration Services delays. Congress continues to debate issue. In the meantime, local governments are left to deal with a population without legal status, and constituents with mixed opinions on the topic.

Amnesty critics argue that the United States is already overpopulated and that lawmakers need to crack down on illegal immigration, not promote it. Granting amnesty increases the size of the U.S. population, they say, which negatively impacts the environment. It also burdens taxpayers who must pay for extra social services, with their immigrant-driven depressed wages. Besides pardoning illegal immigrants is wrong, amnesty opponents argue. It penalizes legal aliens who have properly followed the rules, and delays the immigration of those patiently waiting aboard. Granting amnesty also rewards criminal behavior and encourages others, especially family members, to follow the same path. Worst, it undermines the public trust, as past amnesties were promised to be "the last." Those against amnesty do not believe the government should make

\footnotetext{
${ }^{78}$ The bill was featured in the documentary "The Senate Speaks," story 11 in How Democracy Works Now: Twelve Stories by Shari Robertson and Michael Camerini.

${ }^{79}$ A Day Without a Mexican (2004).
} 
everyone legal just because it might be more convenient than deportation. The process of granting legal immigration status, they argue, is even more troublesome. It creates a costly bureaucratic nightmare.

Amnesty supporters believe a massive deportation is unrealistic. Locating and sending people back to their home countries would be logistically difficult and expensive, they claim. Besides, expelling people seeking to improve their lives simply because they lack legal documents also violates basic human rights. Many unauthorized immigrants have family members, including children, who are citizens or legal residents. Every effort should be made to keep families intact. That is in the best interest of the children and society-at-large, say those advocating for compassion. Besides these individuals have resided, worked, and contributed to their new communities for years. They have earned the right to remain in the country and to apply for citizenship. Forgiving the crime of illegal entry will give them a chance at self-sufficiency and social mobility, argue those who favor amnesty. Allowing such a substantial portion of Americans to live "underground" harms the whole community.

Regardless of which side of the debate resonates with local leaders, failure to reform national immigration laws has caused city officials to do the job of the federal government—-grant de facto urban citizenship to residents, or force foreign nationals to leave the city limits. Having residents who work in an underground economy and cannot access public health and safety services (due to ineligibility or fear of deportation) creates difficult situations for municipal government. 


\section{Worksite deportation raids}

Other provisions of the Immigration Reform and Control Act were designed to crackdown on foreign in-migrants who entered the country illegally to find work. The first section of IRCA instituted civil and criminal sanctions against employers who knowingly hire (or recruit, harbor, or refer for a fee) a non-U.S. citizen without authorization to work in the United Sates. It requires employers to file an I-9 form for each worker, stating that the employer has verified that the employee is legally allowed to work in the United States. Employees can prove their legal status by allowing the employer to examine their passport, birth certificate, Social Security card or alien documentation. Employers who violate the law face fines and perhaps even jail time. These "employer sanctions" were supposed to give employers an incentive to hire nativeborn or legal immigrant workers instead of unauthorized aliens. The Immigration and Naturalization Service (INS) was charged with IRCA law enforcement. ${ }^{80}$ The agency relies on worksite raids to accomplish this task. Migrants caught in the crack downs are deported.

Local enforcement of IRCA provoked renewed criticism about the fairness of United States immigration laws. Critics argue that raids hurt local economies. Rounding up undocumented immigrants at urban worksites creates an unfriendly business climate. It deprives targeted cities of their affordable workforce, and discourages some companies from hiring people who appear foreign. Immigration raids also create the impression that raid-marked cities are less hospitable than other cities to industries that rely heavily on

\footnotetext{
${ }^{80}$ In 2003 the law enforcement functions previously performed by the INS were transferred to the Immigration and Customs Enforcement (ICE) arm of the newly formed Department of Homeland Security (DHS).
} 
undocumented workers - like food processing, garment, and furniture companies. Affected localities contend this puts their municipalities at risk. They argue that targeted cities could lose jobs, and millions in tax revenues, if threatened businesses relocate. ${ }^{81}$ Plus, other manufacturing industries, they say, may think twice before moving into a city where costly immigration sweeps take place. Since some cities are subject to more immigration raids than others, local IRCA enforcement practices are perceived to be inequitable by some, especially when the businesses raided are not those with the worst employment violations (Bazar, 2008). Moreover, opponents argue that the problem is not unauthorized immigration, but IRCA itself, a law they contend is out of sync with urban labor needs. It authorizes too few immigrant-worker visas to meet labor demands of expanding regional economies.

On the flip side are local officials who complain about having too many "illegal" aliens. Like immigration raid critics, they also charge federal immigration agents with unfair enforcement practices. But unlike IRCA opponents, worksite sweep supporters criticize Immigration and Customs Enforcement (ICE) for ignoring industries that outsource jobs to migrants in their towns. These businesses, they contend, hurt cities by attracting unauthorized workers who undermine wages and drain scarce municipal resources. They want ICE to step-up IRCA enforcement efforts in their jurisdictions. Others have lost faith in federal immigration officials all together, and are tired of waiting

\footnotetext{
${ }^{81}$ Unlike restaurants, hotels, yard maintenance and construction industries, these manufacturing operations can actually move to places where more affordable labor is available and fewer sweeps occur.
} 
on congress to overhaul the nation's immigration laws. These municipalities advocate ado-it-yourself approach to eliminating incentives for "illegal" immigration. Homegrown IRCA measures, they believe, are the best way to do that.

Another issue that frequently arises focuses on the moral validity of IRCA law enforcement. Those making an ethical case against immigration sweeps argue that ICE practices are notoriously unfair. Workers, not employers, are disproportionately punished. ${ }^{82}$ Few businesses have been fined under the law, whereas numerous workers have been arrested and deported.

A related accusation has to do with the rights accorded a city's unauthorized workforce. It broadens the debate by focusing on the impact of raids on migrant workers. Defenders of the "undocumented" say crackdowns deprive migrants of the right to work and pursue a decent life. They also terrorize immigrant families. The forcible separation of youngsters from their parents, which occurs as a result of worksite raids, tears apart migrant families and traumatizes the children of "illegal" aliens arrested in the crackdowns. This, opponents argue, is unfair to U.S.-born children who fear losing one or more parent in sweeps, or in some cases, are abandoned or held in foster care while ICE detains their parents. IRCA enforcement opponents want local government to protect the city's unauthorized workforce from intimidation by federal agents. Responsive municipalities justify their actions in terms of public safety. Military-style immigration raids, they argue, promote discrimination and push frightened immigrants deeper into the urban shadows where they can be more brutally exploited.

\footnotetext{
${ }^{82}$ While workplace arrests rose tenfold from 2002 to 2008 , from 510 to 4,940 , only 90 criminal arrests involved company personnel officials (Hsu, 2008).
} 
The contrary view is that "illegal" immigrant parents, not ICE, are to blame for adversely affecting their children. City officials that favor stricter control on immigration think ICE should keep the pressure on undocumented workers, and should focus even more attention on their employers. From this perspective, the "undocumented" have no right to be in the United States and thus, should not expect to be protected by any of the rights that U.S. citizens and legal residents have.

Beyond the economic and humanitarian issues, others say raids are not effective deterrents to undocumented immigration. Allowing police to assist in raids on local businesses is a waste of limited law enforcement resources, argue some city officials. Similar complaints are made about employer sanctions.

Those opposed to employer sanctions contend that any process for screening employees can be beaten. Besides, they point out, in certain industries unauthorized immigrants are not likely to apply for work. Therefore, requiring every single U.S. employer to screen documents burdens employers with unnecessary bureaucratic paperwork, which, they contend, undermines the competiveness of U.S. business. Besides that, it turns private citizens into INS informants, which civil libertarians fear represents a step towards a police state. Opponents of employer penalties want federal agents to do a better job of keeping illegal workers out of the country in the first place. From this view, the costs of employer sanctions far outweigh their deterrent benefits. Supporters claim employer sanctions are necessary in order to achieve a sense of fairness. Employers who exploit "illegals," they argue, should bear some of responsibility for creating incentives for aliens who sneak into the United States. 


\section{The devolution of immigration law enforcement}

Since the mid-1990s, and to even a greater extent since 2001, the federal government has acted to increase the role of police in the interior enforcement of U.S. immigration law. First, Congress sought to restrict the ability of local government to limit INS-police cooperation. Section 642 of Illegal Immigration Reform and Immigrant Responsibility Act (IIRIRA) of 1996 outlawed city bans on sharing information about citizenship or immigration status with the INS. ${ }^{83}$ The Welfare Reform Act, passed the same year, also included a provision to the same effect. ${ }^{84}$ The legislation was a backlash to local sanctuary policies adopted during the 1980s (NILC, 2004b; Kalhan 2008; Mitnik \&Halpern-Finnerty, 2010).

Next, congress authorized (but did not require) police participation in civil immigration enforcement under certain conditions (Appleseed, n.d.; Kalhan, 2008). Section 439 of the Antiterrorism and Effective Death Penalty Act (AEDPA) of 1996 allows police to arrest and detain an alien if that person is unlawfully present in the United States, and has been previously convicted of a felony. ${ }^{85}$ Section 372 of the IIRIRA created new rules for deputizing local officials in the event of a "mass influx" of immigrants (Smith, 2003; Kretsedemas, 2008). ${ }^{86}$ This provision was expanded to apply in nonemergency situations when Section $287(\mathrm{~g})$ of the INA was amended. ${ }^{87}$

\footnotetext{
${ }^{83}$ IIRIRA codified at 1373 (a).

${ }^{84}$ PRWORA $\S 434$ codified at 8 U.S.C. $\S 1644$.

${ }^{85}$ AEDPA codified at 8 U.S. C. $\S 1252 \mathrm{c}$.

${ }^{86}$ IIRIRA codified at 8 USC $\S 1103(\mathrm{a})(8)$.

${ }^{87}$ INA $\S 287(\mathrm{~g})$ codified as 8 U.S.C. $\S 1357(\mathrm{~g})$.
} 
Section $287(\mathrm{~g})$ allows the Secretary of Homeland Security (or Attorney General, prior to 2003) to enter into voluntary agreements (called memorandums of understanding, or MOUs) with local authorities to formally involve them in immigration law enforcement. Cities that sign MOUs can have segments of their police forced trained and certified to act as immigration agents. Deputized police officers are authorized to investigate, apprehend, and detain anyone suspected of being in the United States unlawfully (Edwards, 2003; NILC, 2004b; Waslin, 2010) ${ }^{88}$ Early attempts at MOUs under the $287(\mathrm{~g})$ program were not successful (Appleseed, n.d.). ${ }^{89}$

Efforts to enlist localities in immigration enforcement gained momentum after the September 11, 2001 terrorist attacks on the United States. MOUs became more common (Waslin, 2010), when Congress passed the USA Patriot Act. ${ }^{90}$ One of its most controversial provisions is Section 215. It allows investigators broad access to the personal records of non-U.S. citizens, and prevents the recipient of such an order-police officers, librarians, health care personnel, school teachers, accountants and Internet service providers--from disclosing the request. Another provision makes it easier for federal agents to detain and deport suspicious aliens identified by federal agents, or citizens doing the job of the INS. ${ }^{91}$

Plans and policies from the Department of Justice and Homeland Security also created new avenues for local-federal cooperation. In 2002, the Department of Justice (DOJ) reversed its opinion on police involvement in immigration. The DOJs new view--

\footnotetext{
${ }^{88}$ Local law enforcement officials without training or experience in immigration law are not allowed to enforce these laws in the normal course of their duties (Waslin, 2010).

${ }^{89}$ This provision was not implemented until after 9/11 (Kalhan, 2008).

${ }^{90}$ PL 107-56 (October 26, 2001).

${ }^{91}$ USA Patriot Act $\S 421$.
} 
released in a memorandum kept secret until a 2005 court ruling made it public--is that police have "inherent authority" to enforce noncriminal infractions of immigration law. This was a stunning departure from its previous opinion, and overturned decades of legal precedent. Traditionally, civil immigration violations - such as overstaying a visa or being illegally present in the United States—-were considered a federal responsibility. State and local agencies were only permitted to enforce criminal violations, such as people smuggling (Kalhan, 2008; Waslin, 2010). ${ }^{92}$ After making the internal announcement, Attorney General John Ashcroft encouraged local jurisdictions to accept their new enforcement responsibilities. Police were called upon to assist with the investigation, interrogation, and arrest, of nonimmigrant Muslim visa over-stayers of Middle Eastern and South Asian descent (Appleseed, n.d.; Kalhan 2008).

That same year, the INS was abolished and its immigration functions transitioned into two offices of the Department of Homeland Security (DHS): the U.S. Citizenship and Immigration Services (USCIS), and the Bureau of Immigration and Customs Enforcement (ICE). ${ }^{93}$ As a result, civil immigration enforcement efforts were recast as security-related, criminal priorities and repositioned within the longstanding federalstate-local partnerships designed to combat serious crime (Kalhan, 2008). Also, new funding allowed ICE to more aggressively pursue MOUs with police departments across the country, while other DHS programs and services encouraged ICE-police cooperation

\footnotetext{
${ }^{92}$ For more on the history of legislation and court decisions leading to devolution of immigration law enforcement authority, see the legal section of Appleseed, "Forcing Our Blues into Gary Areas," http://www.appleseeds.net/Portals/o/Documents/Publications/forcingourbluesintograysweb.pdf . ${ }^{93}$ Homeland Security Act of 2002 (PL 107-296).
} 
in a more indirect fashion with no MOUs required. Two of the most controversial initiatives are the National Crime Information Center (NCIC) Database and the Secure Communities program.

By entering hundreds of thousands of civil immigration records into the FBI's main criminal database--the NCIC, ICE has tried to induce police officers to arrest and detain suspected immigration violators whose names appear in the database. Local police query the NCIC database millions of times every day as part of their routine duties (Appleseed, n.d.; Kalhan 2008). Under the Secure Communities program, which launched in March 2008, police indirectly help ICE deport immigrants. Participating jails submit arrestees' fingerprints not only to criminal databases, but to immigration databases as well. This allows ICE access to information on individuals held in jails. If federal agents identify an immigration law violator, ICE can ask a municipality for a "detainer" to hold that person for up to 48 hours. The program, originally designed to target the "worst of the worst" offenders, has led to the deportation of people whose only offense was violating civil immigration law. The technological presence of ICE in local jails has also generated concern about police being seen as immigration agents.

While these activities have blurred the traditional distinction between federal and local law enforcement agencies, none are mandatory. A few pieces of federal and state legislation attempted to change that. A congressional proposal introduced in 2003--the CLEAR Act--would have required local police to enforce civil immigration laws or risk losing federal funding. ${ }^{94}$ Widespread opposition killed the bill. In April 2010, Arizona governor Jan Brewer signed into law SB 1070, also known as the Support Our Law

${ }^{94}$ Clear Law Enforcement for Criminal Alien Removal, H.R. 2671, $108^{\text {th }}$ Cong. (2003) (“CLEAR Act”). 
Enforcement and Safe Neighborhood Act. One provision requires police to demand proof of legal status if an officer has "reasonable suspicion" that someone might be an unauthorized immigrant. Officers can detain a person who does not produce such evidence. Citizens and naturalized residents are not required to carry proof of citizenship. This devolution of immigration law enforcement authority has fueled a fierce debate. Those who favor an increased role for state and local police argue that mass immigration has overwhelmed the proper administration of the law. They believe the federal government needs the increased capacity—or force multipliers—-that state and local agencies provide in the fight against terrorism and unauthorized immigration. With an estimated eleven million "illegal" aliens residing in the U.S., and fewer than 2,000 trained federal immigration agents, police assistance is solely needed (Numbers USA, n.d.). Since local law enforcement officers already come into contact with illegal aliens in the course of their daily duties, it makes sense to enlist their support. The vast majority of these officers believe in the rule of law, supporters claim, and want to help protect the security of their country (“Cities/Counties Boycotting,” 2010).

Critics, meanwhile, argue that most unauthorized immigrants are not national security threats, and most police officers are not interested in becoming immigration agents. Police are supposed to protect people, not enforce immigration law. Actual or perceived police participation in civil immigration enforcement, they contend, jeopardizes community policing and erodes — rather than promotes - trust between immigrant communities and the police. When police are turned into immigration agents, immigrants who are victims or witnesses of crime avoid cooperating with police. Their 
fear of apprehension and deportation puts entire communities at risk. Besides, enforcing immigration law is costly. The federal government does not cover the costs incurred by localities that enforce immigration law. This means limited resources are diverted away from the investigation of serious crimes. This money could be better spent on public safety. Police involvement in immigration enforcement also increases response times to emergency 911 calls, and makes racial profiling more likely (which can result in expensive litigation).

\section{Government benefits for noncitizens}

"The public does not approve of natives using welfare benefits, much less newly arrived immigrants" (Gimpel \& Edwards, 1999, p. 284). In 1994, California voters approved Proposition 187. Intense anti-immigrant sentiment sparked by a severe economic recession, and increasing numbers of immigrants of color, prompted the action. The measure sought to limit taxpayer-funded government services provided to "illegal" aliens, including education and nonemergency health care. That same year, six states (Arizona, California, Florida, New Jersey, New York, and Texas) filed separate lawsuits seeking federal reimbursement for the cost of providing mandated services to unauthorized immigrants. Politically, President Clinton could not ignore the challenges confronting states with lots of electoral votes and immigrants. In 1996, he signed the Personal Responsibility and Work Opportunity and Reconciliation Act (PRWORA) into law. $^{95}$

For foreign in-migrants, PRWORA went well beyond conditioning access to cash benefits on work. The immigrant provisions of the welfare reform law (Title IV of

\footnotetext{
${ }^{95}$ PL 104-193 (August 22, 1996).
} 
PRWORA) established a comprehensive scheme for governing refugee and immigrant access to a whole range of social benefits provided by federal, state and local governments (Fix \& Passel, 2002).

Introducing more restrictive eligibility standards for noncitizens was the first part of the plan to crack down on unwanted immigrants. Before welfare reform, legal immigrants living in the United States had the same access to public programs as nativeborn citizens. Now, legal immigrant and refugee eligibility for social services more closely resembles that of unauthorized immigrants. ${ }^{96}$

The law also introduced and institutionalized the practice of distinguishing between different groups of foreign in-migrants. PRWORA's redefinition of immigrant eligibility involved the creation of a series of "bright lines" drawn to separate groups who were eligible for different levels of benefits. One bright line divided "qualified" and "unqualified" (unauthorized) immigrants; another bright line distinguished between "qualified" immigrants and naturalized citizens; and one more line was drawn between legal immigrants entering the United States before August 22, 1996 and those who arrived after (Fix \& Passel, 2002). Espenshade \& Huber (1999) explain the basic pattern of programmatic reductions in eligibility:

Legal immigrants (regardless of when arrived and so long as they have not become naturalized U.S. citizens) are no longer eligible for food stamps, and refugees are eligible for SSI and food stamps only for their first five years in the United States. Legal immigrants present in the United States prior to August 22, 1996, retain their eligibility, whereas, all future legal immigrants are not qualified for SSI until they become citizens and are ineligible for other federal benefits for their first five years in the United States (p. 367).

\footnotetext{
${ }^{96}$ With few exceptions, only citizens are eligible for means-tested federal benefits such as TANF, SSI, food stamps and Medicaid (USCIS 2004).
} 
PRWORA's Title VI also shifted financial support responsibility to immigrants' sponsors. For the first time, sponsors were required to have an income of $125 \%$ of the federal poverty line. Sponsors' new income requirements and open-ended support obligations have made it harder for the poor, and presumably most welfare-prone, immigrants to enter the United States.

Lastly, PRWORA delegated the administration of the Title IV provisions to states. ${ }^{97}$ Following reform, states were granted extensive discretion to limit the eligibility of legal and unauthorized immigrants for federal and state benefit programs; a power previously denied them by the courts. ${ }^{98}$ The law also authorized, but did not require, states to use their own resources to supplement lost federal food, cash, and health-related benefit programs. At the same time, states were restricted from extending benefits to unauthorized immigrants, effectively limiting benefits access for this group. Publically funded agencies are required to verify the legal status of all applicants, and to notify INS officials of persons determined or suspected of being in the United States unlawfully. ${ }^{99}$

With eligibility for federal means-tested public benefits depending more on citizenship than in the past, naturalization rates surged dramatically between 1994 and 1999. Fear engendered by California's Proposition 187, and new limits on noncitizens' procedural rights, also contributed. At the same time, 2.7 million immigrants acquired

\footnotetext{
${ }^{97}$ PRWORA $\S 404$ (codified at 8 USC 1621).

98 "Previously, court ruling that applied the Equal Protection Clause of the Fourteenth Amendment of the U.S. Constitution prevented states from distinguishing between legal immigrants, refugees, and citizens; although illegal immigrants could be denied eligibility for most state programs or federal programs targeted towards citizens" (Espenshade \& Huber (1999, p. 368).

${ }^{99}$ PRWORA § 411A (codified at 42 USC 611a).
} 
legal immigrant status around 1990 under the 1986 Immigration and Control Reform Act and thus, became eligible to naturalize in the mid 1990s (Takahashi, n.d.). The result was a huge backlog.

At the same time, Title VI led to steep declines in public benefit use among all immigrants, even refugees and mixed legal status families who qualified under the law. Confusion among immigrants about who was eligible for benefits, and fear of deportation, discouraged some immigrants from using benefits regardless of eligibility (Takahashi, n.d.). For cities with many foreign in-migrants, the immigrant provisions of PRWORA meant more indigent people on the streets, the risk of communicable diseases spreading, and extra hunger children.

Nevertheless, opinions on welfare and Medicaid benefits for immigrants remain split. Supporters of a liberal interpretation of civic inclusion base their case on constitutional principles. They argue that the 1996 welfare act, which made citizenship a prerequisite for receiving benefits, runs contrary to core U.S. political principles. The Constitution speaks of "We the People of the United States," not "We the Citizens..., and the Bill of Rights is designed to protect the interests of the people, not citizens (Pear, 1994). PRWORA's Title IV is at odds with the Equal Protection Clause of the Constitution, opponents argue, because the provisions violate the antidiscrimination principle and produce stratification. These defenders of individual rights and liberties believe that all individuals who are members of a community should qualify for public benefits on a par with U.S. citizens. 
This position is disputed by those who believe noncitizens do not have the same rights as citizens. They understand the phrase "People of the United States" to mean "citizens." From this view, only natural-born, or naturalized, legal citizens should receive publicly funded benefits. The government has no obligation to noncitizens, PRWORA argue.

Another issue that frequently arises focuses on human rights. Those making a humanitarian case against eliminating benefits for immigrants focus on moral obligations. They claim that PRWORA--by denying noncitizens and their U.S. children access social security and an adequate standard of living--breaches international law. ${ }^{100}$ All humans, PRWOR opponents argue, are entitled to these inalienable rights, regardless of their political membership. No human is illegal from this standpoint. Human rights advocates worry about people who have little or no voice in the electorate being left outside the welfare safety net.

Others are more concerned with meeting the needs of native-born residents. They blame the federal government for not doing more to exclude "illegal" immigrants and also, for admitting more poor legal immigrants than can comfortably be supported. Rather than providing medical care, housing, and cash for foreigners, they argue, we should concentrate on providing for those who were born here. The word "benefit," Title IV proponents argue, implies that the recipient has earned the help. Unauthorized and recent legal immigrants have not contributed enough to deserve collecting government benefits. They are feeding off the system that is set up to help citizens, argue those opposed to government support for non-U.S. citizens. This group favors tighter

${ }^{100}$ UDHR, Articles $22 \& 25$; ICESCR, Articles 9 \&11; and CRC, Articles $26 \& 27$. 
restrictions on welfare eligibility for foreign nationals. They claim it is necessary to maintain the system for "real" Americans, and to reduce the strain on taxpayers. Taxpayers are the ones that need protection, restrictionists argue. Hardworking citizens should not have to foot the bill for needy immigrants.

From this view, foreigners who cannot support themselves should not be in the United States. Removing the welfare incentive to immigrate, goes the argument, deters those most likely to need public assistance from entering or staying in the United States. It also prevents immigrants' sponsors from shirking their responsibilities to provide financial support. Besides, restrictionists argue, free access to public benefits is a "magnet" for the least desirable immigrants-people with less education, skills and income. It gives "illegal" immigrants no incentive to work, follow the laws of the land, or adapt to the nation's culture. From this perspective, giving away free services to unauthorized immigrants is stealing from U.S. citizens. It is unfair to people who obey the law.

Those in favor of government support for foreign in-migrants claim most noncitizens--legal and unauthorized, pay federal and state income taxes, Social Security taxes, and Medicare taxes. And all foreign nationals pay sales and property taxes (even if they rent housing), PRWORA opponents argue. They question the power of the so-called "welfare magnet," and notion that noncitizens use more benefits than U.S. citizens. Those opposed to immigrant exclusion from benefits cite research showing immigrants to be less dependent on welfare than native families. They point out that immigrants pay more in taxes than they receive in government assistance. Besides, say those in favor of 
benefits for noncitizens, many immigrants have lived in this country for decades, married U.S. citizens, and raised their U.S.-citizen children. Laws that punish them violate their fundamental right to fair and equal treatment.

Another position calls Title IV impractical. Critics argue that restricting noncitizen access to publicly financed services is detrimental not only to foreign inmigrants, but also for cities and their native-born constituents. Under PRWORA, almost one million non-citizens lost welfare, housing, and Medicaid subsidies. The burden of replacing these federal "savings" fell on state and local governments, where most of those thrown off the welfare rolls live. As a result, child poverty became more common. The risk of communicable diseases spreading grew, and more medically indigent foreign inmigrants ended up on the streets. If someone is living in the United States it is in everyone's best interests to do what we can to ensure that they lead healthy and produce lives, PRWORA opponents argue, irrespective of immigration status. On the flip side are local officials who argue that Title IV has helped cities. It diverted unwanted immigrants to other locations and freed up funds to spend on voting constituents.

Since it was left to the state and city governments to decide whether to assume, and to what extent, they would pick up the cost of un-restored programs, a patchwork of benefits sprang up across the country in the wake of PRWORA's Title VI. Some local governments provided a safety net for those no longer eligible for assistance. Other municipalities proposed or adopted local proposals that denied or reduced benefits, as way to deflect unwanted immigrants elsewhere. 


\section{"Locally legal" identification cards}

For decades, consulates have issued matrícula consulars (consular registration cards) to Mexicans living aboard who requested them. ${ }^{101}$ The cards are issued without regard to immigration status and give no information about that. ${ }^{102}$ Mexicans in the U.S. legally can and do use the card to simplify reentry in lieu of a passport, although it is most useful to unauthorized immigrants who are less likely to have U.S.-issued identification. Lack of ID prevents "illegal" aliens from accessing the few public and private services that are available to them. It increases their fear of contact with police. The events of September 11, and greater subsequent scrutiny of identity, deepened this anxiety. Mexicans applied for the cards in droves.

Responding to the explosive popularity of the matrícula, the Mexican government began issuing the cards through its network of consulate offices in the United States.

"Mobile consulates" were also set up to issue the card in communities without a

consulate. To convince U.S. authorities that the card was a secure form of identification, the Mexican government upgraded the matrícula to add protection against counterfeiting. It also launched a well-organized campaign to win acceptance of the card at the state and local level. Consulate personnel met with police departments, bank officials, and governments to encourage them to accept the matrícula as a valid form of ID (Dinerstein, 2003; Hudson, 2003; O’Neil, 2003).

\footnotetext{
101 "The ID card is a way for the Mexican government to keep track of its citizens for consular and tax purposes, collect data on them, and provide them with what the government considers to be a basic human right: the ability to identify oneself' (O'Neil, 2003).

${ }^{102}$ To obtain a matrícula consular card, an applicant must appear in person and present the following documents: (1) a birth certificate or other document demonstrating Mexican citizenships; (2) a document with a picture demonstrating identity, such as a voter identification or driver's license; and (3) proof of a local address in the United States, such as a utility bill (Bruno \& Storrs, 2005).
} 
The new version of "high security consular registration card" includes the telephone number of the local Mexican consulate office (for card verification purposes) and the U.S. address of the bearer, which is information banks and police want. Each wallet-size card also has the photograph, name, date and place of birth, and signature of the holder, as well as a serial number and date of expiration. It is valid for five years and costs about \$29. The laminated card was first introduced in major metropolitan areas in 2002, and gradually made available in consulate areas throughout the United States (Bruno \& Storrs, 2005). By 2005, matrícula consulars were formally accepted by 1,204 police agencies, 393 cities, and 168 counties (Varsanyi, 2007). Many telephone and utility companies, hospitals, and video stores also accepted it. Where recognized, the card makes city services more accessible to immigrants who have one.

The Mexican ID card has drawn heated debate. Those who support acceptance of the matrícula point out that the card is issued solely for identification purposes. It does not confer any type of legal immigration status. They maintain that recognition of the card is necessary in a post-9/11 world in which photo identification is required to conduct daily business. This acceptance benefits not only the holder, but banks and other institutions as well. It also cuts down on the burgeoning fraudulent document trade, and allows otherwise marginal individuals to participate more openly in mainstream life.

Opponents of matrícula consular acceptance argue that the card is only needed by aliens without access to other legitimate identification documents. They maintain that the ID card helps unauthorized Mexicans live and conduct business in the United States. In so aiding them, opponents charge, the card confers quasi-legal status on "illegal" aliens 
and subverts U.S. immigration law. They view efforts to gain widespread acceptance of the card as part of a larger plan to circumvent Congress, which, after September 11, has been reluctant to grant amnesty to millions of immigrants living in the United States. More broadly, critics argue that municipal acceptance of the matrícula interferes with the federal government's ability to set immigration policy, and subjects cities to lawsuits. The Constitution reserves foreign policymaking for the federal government, they point out.

Aside from aiding and abetting "illegal" immigration, opponents argue that accepting consular ID cards comprises our homeland security. It places critical national security matters in the hands of the foreign governments that issue these cards. They maintain that changes since $9 / 11$ have been put in place to make it harder for people who are not supposed to be here to remain. By accepting the Mexican ID cards, businesses and local governments are working at odds with the federal government's homeland security efforts. They further content that accepting the matrícula sets a dangerous precedent, since other less friendly countries may decide to issue similar cards to their nationals in the United States.

Supporters of the matrícula consular argue that the card improves homeland security by enabling authorities to easily identify Mexican nationals living in the United States. Individuals who are isolated and marginalized, they maintain, pose a greater potential security threat than those who are known. They emphasize that Mexico is not a terrorist-supporting country and that Mexicans come to the U.S. to work, not commit terrorist acts. 
Another issue that frequently arises focuses on public safety and law enforcement. Supporters argue that the consular ID card is secure and fraud-resistance. Mexican officials maintain that the documents presented to obtain the card are properly authenticated, and their database prevents the issuance of duplicate and fraudulent cards. The Mexican identification cards, they say, are as secure as many U.S.-issued documents, including driver's licenses.

Matrícula supporters take the position that when law enforcement agencies accept the ID card, public safety improves. Clearly there is a benefit to police departments and others knowing who they are dealing with. Aliens with identification are also more likely to work with authorities to resolve crimes and other social ills, proponents add. Acceptance of the matrícula consular by financial institutions also has public safety benefits. Individuals who can open bank accounts do not have carry around or stockpile large amounts of cash, which makes them easy targets for home invasion and robbery. Advocates say the card provides Mexican immigrants a way to better function in a society, where they contribute with their labor but are often excluded from obtaining even basic services.

Critics question whether undocumented immigrants should have access to such services. They call consular ID programs magnets for "illegal" aliens. Opponents of matrícula acceptance also challenge the assertion that the card is a secure document. They argue that despite its fraud-resistance features, the card is not secure, because Mexican birth certificates, which are used to obtain the card, are easily forged. They further maintain that acceptance of the consular ID by law enforcement agencies 
threatens public safety. In cases of minor law violation, police departments that recognize the card do not conduct background checks or take fingerprints of card holders. Given this practice, opponents argue, the card helps conceal past criminal activity.

\section{Unregulated day labor-contractor market exchanges}

In the 1990s, many mid-size cities and suburban areas experienced an increase in the number of day laborers ${ }^{103}$ congregating on street corners and in parking lots. ${ }^{104}$ These sites were transformed into areas of unregulated market exchange between casual workers and the drive-by contractors or homeowners who hire them. ${ }^{105}$ Unlike migrant farm workers, urban day laborers are highly visible. They are concentrated in places were native-born residents drive and shop. Most are recently arrived Latino immigrants, many are undocumented (Valenzuela, 2000). Consequently, day labor sites have become flashpoints in the local immigration debate. To many, day laborers symbolize the federal government's failure to enforce or reform immigration laws. As a result, despite the relatively small size of the day labor market, the presence of day laborers in many communities has generated a lot of complaints.

\footnotetext{
${ }^{103}$ A day laborer is a laborer who offers himself/herself for hire for a day, or some other are temporary basis, and who gets paid at the end of the day. These laborers typically work in construction, light manufacturing, landscaping, and other similar jobs. Day laborers find work either through a temporary day labor center or by waiting in a parking lot or on a street for an employer to arrive and hire workers as needed (Workplace Fairness, 2013).

${ }^{104}$ Three factors are responsible for the approximately 117,600 workers gathering at nearly 500 sites across the country everyday: a recent surge in illegal immigration, the growth of part-time contingent labor, and the explosion in the home-improvement business and do-it-yourselfers in need of helpers (Valenzuela, Theodore, Meléndez, \& González, A. 2006, p. 4).

${ }^{105}$ Day labor markets are generally part of the informal economy, meaning workers and employers enter into agreements that are not usually reported to the government and do not conform to various labor regulations (Valenzuela, 2000; Gonzalez, 2007).
} 
Business owners fear that crowds of mostly male, usually Latino, day laborers will scare off Anglo customers. They want the workers ban from the area, or at least dispersed. Neighborhood critics call day labor sites eye sores. They blame day laborers for ruining the quality of community life. Trades people complain that day laborers undercut wages and push native-born workers out of their jobs. Individuals and groups opposed to unauthorized immigration believe day laborers are in this country illegally, and thus by definition, they are criminals. They bitterly oppose any measure that might help unauthorized immigrants, who they want locked up and deported.

Local governments that support day laborers face the threat of lawsuits generated by activist groups, or ousting by voting taxpayers. The former claim facilitating the hiring of unauthorized immigrants violates federal law. ${ }^{106}$ The latter do not favor supporting a non-taxpaying population. They want public funds directed toward activities and services for local citizens.

On the other side of the debate are day labor advocates pressing local authorities to protect day laborer rights. Their main argument is that laborers, even if some are "illegal," have a constitutional right to stand on public sidewalks and solicit work. Policies that chase off day laborers, or their bosses, rob workers of their constitutional right to seek economic opportunities. Supporters say the workers are simply trying to make an honest living and are crucial to local economies. Little would get built in the United States without foreign-born labor, contractors say; unauthorized immigrants often

\footnotetext{
${ }^{106} 8$ U.S.C. $\S 1324 a$ (a) (1) (A) (2005) states: "It is unlawful for a person or entity...to hire, or recruit or refer for a fee, for employment in the United States an alien knowing the alien is an unauthorized alien." There is no legal standard for regulating a largely illegal day labor market (Feere, 2007).
} 
fill jobs that Americans no longer want. ${ }^{107}$ They also keep industries dependent upon sweatshop labor afloat, and provide do-it-yourselfers with a cheap source of weekend help. Since there is a high demand for their work, advocates demand officials protect vulnerable day laborers from exploitation and abuse. ${ }^{108}$ Workers hired from the street often get ripped off by unscrupulous employers. Other times they get stuck with dangerous, toxic jobs with no safety protections. Day laborers are also harassed by federal agents and local police, neighbors, merchants, and anti-illegal immigration activists (Workplace Fairness, 2013). Workers want local government to protect them from crooked employers and bullies who prey on them.

The way local governments respond to these issues varies city-to-city across the United States. A snap shot of this patchwork of locally generated immigration policy is presented next.

\section{A Typology of Municipal Unauthorized Immigration Policies in U.S. Cities}

Comparing a wide range of municipal actions on unauthorized immigration requires a system for squeezing some order out of what looks like a mass of unrelated and chaotic information. With that in mind, I offer two ordering schemes-one related to different policy domains and issue areas, the other to the policy alternatives. Combining these classification schemes creates an analytic framework that can be used to compare policy across a large number of cities and policy domains, or track policy development trends in one city over time. The construction of this model is discussed in chapter 2.

\footnotetext{
${ }^{107}$ With recent generations of American kids steered toward college and computer skills, manual labor and time-honored trades have suffered; there's a stigma that if you get your hands dirty, you're a second-class citizen (Simpson, 2001).

${ }^{108}$ Day laborers are frequently transient, or noncitizen immigrants unfamiliar with the English language or the legal system or both, which makes them susceptible to mistreatment.
} 
Information derived from my exploratory research provided the raw material for developing the typology. This data is presented in Appendix B. It is not a full description of policy behavior in any city. The purpose is to provide a national context within which to situate case studies, and to offer a framework for future research. Here are some notable highlights.

There are far more positive or pro-immigrant responses to unauthorized immigration issues than negative examples. Cities crafting policy to protect the rights of residents without legal status have been at it longer than localities with deter and deflect settlement agendas.

All the local immigration control, or anti-illegal immigrant measures, identified in this study were adopted in the last decade. The bulk of these policies originated from new immigrant destinations (in rural areas, small towns and suburbs) that were primarily nonHispanic white a generation ago. People in these places had little prior exposure to native-born minorities let alone aliens with very differ languages, religions, and cultural conventions. A new trend in immigrant settlement, away from traditional gateway cities into inexperienced localities with cheap housing and sweatshop jobs, ${ }^{109}$ accounts for the newcomer influx. Latino-ization threatened to destroy the Eurocentric identity of these communities.

\footnotetext{
${ }^{109}$ According to the U.S. Government Accountability Office, a sweatshop is an employer that violates more than one federal or state labor law governing minimum wage and overtime, child labor, industrial homework, occupational safety and health, worker's compensations or industry regulations. Today, sweatshops flourish beyond the traditional garment and meatpacking industries to include: high-tech manufacturing, construction, and service industries (e.g. work in restaurants, landscaping, car washes, auto repair, and domestic work).
} 
Local governments in some highly diverse, established gateways (like liberal Los Angeles and Vista City, California) also passed immigration control measures during this period. Middle class citizens in these status conscious cities became intolerant of large scale settlement of poor, 'backward' immigrants, most from Mexico and Central America, who violated middle class job and housing standards.

In both cases, federal inaction on immigration reform, coupled with pressure from locally-stationed national anti-immigration lobby groups, prompted municipal action on unwanted immigration.

Other cities responded differently. The first urban citizenship policies were adopted in the 1980s. For the most part, the pursuit of these sanctuary protections were a response to federal policies and practices that discriminated against city residents without legal status, or ignored human rights violations against this vulnerable group. Big cities (e.g. Detroit, Michigan; San Francisco, California; New Haven, Connecticut; Seattle, Washington; St. Paul, Minnesota), midsize towns (e.g. Santa Cruz, California; Ithaca, New York; Boulder, Colorado); and small places with liberal colleges (e.g. Takoma Park, Maryland; Swarthmore, Pennsylvania) adopted these measures. Some of these places have lots of diversity and foreign-born residents, others have little of either. What unites these municipalities is a large population base with an equalitarian outlook and belief in human rights principles. In these "human rights cities," citizens, and their elected leaders, hold inclusive perspectives on the membership of unauthorized immigrants. They make no distinctions between citizens and foreign in-migrants—-egal or "illegal." Local governments in these localities actively intervened on behalf of unauthorized immigrants 
because it was morally right to do. The first laws adopted coincided with the larger progression of City Hall into foreign policy affairs, which included municipal activism on international issues like South African divestiture and nuclear freeze agreements. Religious leaders in the sanctuary movement, and leftie college and university students, were key municipal partners.

The aim of both pro- and anti-illegal immigrant measures is threefold: to address controversial local issues associated with unauthorized immigration; effectuate change in public opinion on the topic; and urge local governments in other cities, or at the state and federal level, to shift their policies in accordance with local ideas about the rights of residents without legal status.

In terms of quantity, the most policy options on both the pro and anti-illegal immigrant side are those related to the day labor issue. Day laborers have come to symbolize the nation's faulty immigration system. Their high visibility makes these workers an easy target for citizen complaints and homegrown measures to address those grievances. There are also a lot of different policy options on police involvement in civil immigration enforcement, but very few for foreign-issued identification cards. The proliferation of police policy on foreign nationals can be traced to the devolution of immigration enforcement authority which began in the 1990s and escalated after the September 11, 2001 terrorist attack on the United States. Municipal ID policy is related to 9/11 as well. Asylum for unauthorized refugees and federal deportation raids also sparked a lot of local policy action, most of it on the pro-sanctuary side. Policy on public benefits for noncitizens ranked fourth in importance, the bulk of it against unauthorized 
immigrant access to key services. Welfare is despised generally, and administered at the county-level, accounting for a smaller number of policies. The fewest policies are those pertaining amnesty for unauthorized immigrants. In all issue areas, intercity copycatting is common. Local governments track and follow the measures adopted by similarly oriented trendsetters, passing similarly worded initiatives in their cities.

To achieve their policy objectives, city officials employ a wide range of tactics. These strategies go well beyond lawmaking, law enforcement or the provision of public benefits. They also rely on other domains of municipal authority including: urban land use and planning, contracting and litigation, finance appropriation and public works authority, property management, legal opinion, lobbying, and off-the-record practices, like turning a blind eye to local violations of federal immigration law. 


\section{CHAPTER 5}

Case Study Results

This chapter provides a detailed, contextualized description of immigration policymaking in three U.S. cities--Sacramento, California; Denver, Colorado; and Portland, Oregon--between 1985 and 2010. I focus on municipal response to the six locally important immigration debates described in chapter 4 . These cities are not necessarily representative of all cities in the United States. They were chosen because they illustrate the social diversity variables hypothesized to shape municipal immigration policy. The discrete decisions made by local government in these cities culminate in immigration strategies.

Sacramento, California Population of $466,488^{110}$

\section{City Profile}

Sacramento is the capital of California and the county seat of Sacramento County. It is located about 100 miles from the Silicon Valley and near the site of the historic UFW Salad Bowl Strike. ${ }^{111}$ Sacramento was gateway for immigrants early in the twentieth century. Today it has re-emerged as one of the nation's hot spots for immigration growth. ${ }^{112}$ Foreign-born residents account for nearly one-quarter $(22.3$

\footnotetext{
${ }^{110}$ U.S. Census Bureau, Census 2010.

111 The Salad Bowl strike, between the UFW and Teamsters for the right to represent Salinas-area farm workers, began in August 1970 and consisted of a series of work stoppages, mass pickets and boycotts which led to the largest farm worker strike in U.S. history and the passage of the California Agricultural Labor Relations Act in 1975.

${ }^{112}$ A 236.5 percent increase in the capital's foreign-born population over the past two decades (Singer, 2004).
} 
percent) of the city's total population, which is lower than the rest of the state (26.8 percent), but higher than the United States (12.4 percent). ${ }^{113}$

In 2002, Time magazine named Sacramento America's most diverse city (Stodghill \& Bower, 2002). ${ }^{114}$ What is striking about Sacramento is the diversity of its immigration stream. The city's demographic hodgepodge defies the stereotypical view of California immigrants as heavily Hispanic. Mexico is represented, but not so much as in other parts of the state. ${ }^{115}$ Sacramento is a true "melting pot metro" (Frye, 2006; Weaver, 1999). While other cities tend to have large concentrations from one or more countries, Sacramento attracts people from all over the world. ${ }^{116}$ The capital is a hub for refugees from the former USSR and Laos, and of late a port of entry for Latino immigrants (Suro \& Singer, 2002; Passel, 2006; Singer \& Wilson, 2007; Twohy, 2011). Many of the newcomers are refugees fleeing persecution in their native countries, which is what distinguishes it from other "re-emerging" gateway cities in California (Bazar, 2004a).

Thanks to a diverse mix of foreign in-migrants, and the arrival of African Americans from the San Francisco Bay Area, Sacramento has become one of the fastest growing, ${ }^{117}$ and most racially/ethnically balanced places in the United States (Bizjak \& Wong, 1991). In Sacramento everyone is a minority—including nonHispanic whites. The

\footnotetext{
${ }^{113}$ U.S. Census Bureau, Census 2010.

${ }^{114}$ Sacramento's diversity rating was based on research conducted for Time by the Civil Rights Project of Harvard. The U.S. Census Bureau also groups Sacramento with other U.S. cities having a "high diversity" rating.

${ }^{115}$ The Sacramento region is home to only 2 percent of the state's immigrants from Latin America.

${ }^{116}$ According to 2000 census figures, the top 10 countries of origin for Sacramento's immigrants are Mexico, the Philippines, Vietnam, Laos, Ukraine, China, India, Canada, Russia and Thailand.

${ }^{117}$ The city's population shot up by 14.7 percent in the 1990s, building on its massive (34.7 percent) growth in the 1980s. Sacramento ranked 52nd in the United States in 1980 and by 2000 it had moved to $40^{\text {th }}$ place, after gaining 131,334 new residents during the 20-year period. Most of the migration is from other places in California.
} 
Anglo-white population dipped below 50 percent in the 1990s, even though the city got about 5,000 new residents from Eastern Europe. Now, African Americans (blacks), Latinos, Asians, and non-Hispanic whites all represent significant shares of the city's population—14.6 percent, 26.9 percent, 18.3 percent, and 34.5 percent respectively. ${ }^{118}$ Sacramento's diversity is also experienced at the neighborhood level. The city has the most integrated neighborhoods of any large city in the state, according to the Public Policy Institute of California. ${ }^{119}$ A second-generation Chinese American, who lives in one of those neighborhoods, explained integration in Sacramento this way: "Diversity tends to attract diversity" (Magagnini, 2002, p. A1).

There are far fewer undocumented immigrants in the Sacramento area than in other parts of California. According to Public Policy Institute of California estimates, Sacramento County has an unauthorized population of 10 percent to 15 percent, which is just 4.6 percent of the county's total population (Hill \& Johnson, 2011). A recent poll indicates that an overwhelming majority think Sacramento is hospitable to undocumented immigrants and a good location for ethnic minorities to live (Lui et al., 2007). ${ }^{120}$

One of Sacramento's strengths in attracting people to the city has been its diverse stock of housing, especially affordable housing, which stayed affordable even during the dot com boom. The median value of housing in Sacramento $(\$ 128,000)$ was slightly

\footnotetext{
${ }^{118}$ U.S. Census Bureau, Census 2010.

${ }^{119}$ The Institute used a complex formula based on census and other demographic data to compile the diversity index used for the rankings. In 2000, Sacramento had a "diversity score" of 81 out of a possible 100 , with 40 percent of the city's census tracts having very high diversity scores. Only 20 percent of the tracts in Sacramento were segregated (Sandoval et al., 2002).

${ }^{120}$ The 2007 Sacramento State Annual Survey of the Region.
} 
above the $\$ 119,600$ national average, but considerably below California's $\$ 211,500$ median value. ${ }^{121}$ An abundance of cheap land has kept housing prices low.

The city's economy is broadly based. Government and transportation are the largest sectors of employment in the area, and agriculture and mining — while still important in the region — have been surpassed by information, technology service, leisure and hospitality, education and health services, and construction. Technology-related companies such as Intel and Hewlett-Packard are among the Sacramento area's largest employers. Demand for both high-tech workers, and low-skilled agricultural and construction laborers, has made Sacramento a magnet for foreign in-migrants.

According to the Sacramento Business Journal, the Sacramento business community depends heavily on the labor of immigrants — both legal and illegal ("International Imports," 2007). The large infusion of Vietnamese and Chinese during the 1990s helped sustain the high-tech industry in the Silicon Valley ("Sacramento's Changing," 1991). Many of the technology businesses in the Sacramento region are headed or formed by well-educated immigrants ("Starting Over," 2007). They also help maintain the government's outdated computer system, and sustain the State's infrastructure and public services (Wadhwa, 2010). Immigrant entrepreneurs from Eastern Europe and Fiji have also started janitorial, nursing and elder-care businesses ("Home Away," 2006). Latino immigrants are concentrated in the construction industry and landscape trade (Twohy, 2011). Construction jobs in Sacramento held steady through the housing slump, according to the State Employment Development Department. When

${ }^{121}$ U.S. Census Bureau, 2000 Census. 
residential construction fizzled, non-residential building continued. The city's relatively small unauthorized immigrant population is concentrated in service, construction and production occupations (“Sacramento's Diverse Workforce,” 2006).

Sacramento is a liberal-leaning city. In a nationwide study of the most conservative and liberal cities in the United States, Sacramento ranked 71 (out of 237 cities) on the liberal list (BACVR, n.d.). The city has long been controlled by Democrats, whose members hold the majority of the seats on the City Council and represent the capital in Congress, the Assembly and the state Senate (Sanders, 2004). Sacramento has a city council manager form of government and tradition of progressive politics, which often drives public policy.

The Sacramento City Council has taken positions on a number of non-municipal issues, namely: apartheid, the Gulf War and Proposition 187 (Moy, 1996). In the late 1980s, the city's political leadership declared Sacramento a comprehensive test ban city, and in the early 1990s, a nuclear free-zone and divestment city (Hobbs, 1994). A message from Mayor Kevin Johnson, published in Sacramento's Sister City brochure, spells out the city's view on the role of government:

Cities play a unique role in international diplomacy. Regardless of form of government, history or the philosophical direction of another nation, Mayors the world over share a unique bond and focus centering on the needs of our citizens. Sometimes those needs transcend national politics or other agendas and allow cities to build relationships that foster peace and cooperation when national governments struggle to find ways to work together (Johnson, n.d., p.2).

Sacramento's official motto is "a city that works for everyone." The city is proud of its reputation as the most integrated city in the United States, and residents consider their city a model of tolerance for the nation and state. 


\section{Unauthorized Immigration Policy}

Permanent residency for the city's authorized population has been the most prominent immigration issue in Sacramento. All other locally important immigration issues are related to this overarching concern. Police involvement in civil immigration law enforcement is a mainstay on the local political agenda. The matter of taxpayersupported public benefits for foreign in-migrants is third in local significance, mostly because debate over the issue set-off a local hate crime spree. The least pressing immigration issues in Sacramento were deportation raids and the day labor dilemma, followed by the Mexican ID card.

\section{Asylum for unauthorized refugees}

In December 1985, the Sacramento City Council passed a resolution expressing opposition to U.S. foreign policy in Central American, and declaring Sacramento a "sanctuary city" for unauthorized refugees from that region. ${ }^{122}$ The nonbinding policy also includes a “don't ask, don't tell” provision to protect its unauthorized population from unfair deportation. That clause directs police and other city employees not to "request information about, or otherwise investigate or assist in the investigation of citizenship or residency status of, any person unless such inquiry or investigation is authorized" by state, federal or city law. It also promises that no municipal employee or department will disseminate information about citizenship or residency status, or consider a person's immigration status in the provision of "City of Sacramento benefits,

\footnotetext{
${ }^{122}$ Sacramento became the $12^{\text {th }}$ U.S. city to declare its jurisdiction a "sanctuary" for Salvadorans and Guatemalans (Lindelof, 1985; Lindsey, 1985).
} 
opportunities or services. ${ }^{, 23}$ The decree calls on the U.S. Congress to recognize fleeing Salvadorans and Guatemalans as "political refugees" and grant them asylum or extended voluntary departure status.

Councilmember Joe Serna Jr. - a Latino rights activist, former Peace Corps worker in Guatemala, son of migrant farm workers and loyal friend of Cesar Chavez-introduced the resolution (Tachibana, 1986; "Sacramento Mayor," 1999). Data showing selective enforcement of refugee sanctuary, and public testimony about the execution of deported Central American asylum seekers, prompted the 5-2 city council vote in favor of the resolution (Lindelof, 1985; Wright \& Herron, 1985; Perkins, 1986; Sanders, 1986a\&c; Tachibana, 1986). ${ }^{124}$ Mayor Anne Rudin voted for the proclamation pitched as a humanitarian measure, saying she was satisfied that her vote would not be interpreted as civil disobedience (Lindelof, 1985). This sudden revolt against federal immigration policy was orchestrated by a powerful coalition of Protestant, Roman Catholic and Jewish sanctuary movement leaders. Initial opposition was small (Lindelof, 1985).

The following month (January 1986), Mayor Rude defended Sacramento's sanctuary status on national television. She squared off in debate with Immigration and Naturalization Service commissioner Alan Nelson in an interview with Today show host Jane Pauley (Chance, 1986). During the six-minute segment, Nelson argued resolutions like Sacramento's undercut national laws, give illegal aliens a false sense of security, and create confusion among police and health officials, who, he said, are unsure which laws

\footnotetext{
${ }^{123}$ Resolution No. 85-973 (adopted December 17, 1985).

${ }^{124}$ Serna's resolution was approved with the votes of Mayor Anne Rudin, then-councilmen Grantland Johnson, Terry Kastanis, and David Shore. It was opposed by Doug Pope and Lynn Robie. Tom Chinn and Bill Smallman did not vote (Sanders, 1987b).
} 
to enforce. Sacramento police will inquire about citizenship status if federal law requires it, Rudin countered, but they will not initiate the questioning themselves. "The police are directed not to make inquiries as to a person's status," she said (Chance, 1986, p. B3). "The reason we passed this policy...is because we feel that the federal government is not enforcing the immigration laws fairly and evenly and humanely" (Chance, 1986, p. B3). Nelson defended the nation's immigration laws as the "fairest in the world" (Chance, 1986, p. B3). In an interview afterwards, Rudin said Nelson "tried to make us look like real lawbreakers" on national television. She complained about Jane Pauley's repeated questioning about the number of illegal aliens in Sacramento. "How do I know?" she told the local reporter Chance, 1986, p. B3).

Three months later organized sanctuary foes surfaced. In April of 1986, several Sacramento groups, supported by the U.S. Immigration and Naturalization Service, formed a coalition and announced their plan to initiate an anti-sanctuary referendum (Tachibana, 1986; Sanders 2006b). ${ }^{125}$ At a post-press conference luncheon, Helen Graham, a leader in the alliance, said the group objected to the resolution because it encourages illegal immigration (Tachibana, 1986). Illegal immigrants are an economic burden and take jobs away from legal residents, added William Carroll, officer in charge for the INS in Sacramento. "I would like to see some evidence of that," Mayor Anne Rudin responded (Tachibana, 1986, p. B3). Councilman Joe Serna, who introduced the resolution, accused the coalition of preying on the fears of local citizens. In a press interview, Rudin and Serna urged the group to refocus its efforts. If the INS didn't play

\footnotetext{
${ }^{125}$ Coalition members included officials from the American Legion, Veterans of Foreign Wars, Californians for Population Stabilization, County Taxpayers League of Sacramento, Citizens for Law and Order, conservative tax crusader Paul Gann and others (McQueen, 1988; Tachibana, 1986).
} 
favorites, they conjectured, the Sacramento City Council would not have passed its resolution. "Immigration laws are very, very unevenly applied," the Mayor added (Tachibana, 1986, p. B3).

A member of the legal community contested Sacramento's sanctuary resolution next. Don Chairez, a private attorney with an immigration practice, delivered an ultimatum to the Sacramento City Council during an emotion-packed July 1986 public meeting: rescind the sanctuary resolution or be sued. "This is a nation of laws, not of people who are anarchists," Chairez argued, adding that the sanctuary resolution turns its back on federal immigration law and sets a dangerous precedent (Sanders, 1986c, p. B3). Chairez's request died when no council member moved to amend or rescind the resolution, and Rudin dismissed the issue without further discussion (Sanders, 1986b\&c).

The decision to stick to sanctuary brought an angry reaction from some in the standing-room-only crowd of about 150 people gathered in council chambers (Sanders, 1986b\&d). Spectators were sharply divided on the issue. According to news report, some felt the council had no business considering a foreign policy issue. Others complained that the sanctuary resolution was too narrow. Still more saw it as a heroic, symbolic stand against the federal government (Sanders, 1986c). Several near fights broke out between supporters and opponents. They pointed figures and shouted at each other and council members. Mayor Anne Rudin asked spectators to leave the council chambers when their noisy reaction delayed the meeting (Sanders, 1986c). In a press interview afterwards Rudin said she had no intention of complying with Chairez's demand. "I'm not a lawyer 
and I don't know if it's ever been tested," she said of the resolution, "The only way we'll ever know is if he brings it to court. Let him file a suit" (Sanders, 1986a, p. B3).

Helen Graham, state coordinator of Californians for Population Stabilization and leader of a local coalition opposing the sanctuary resolution, told reporters that her group was considering a recall drive against sanctuary backers on the council. "This is politics at its worst," she said in reference to Councilman David Shore's alleged broken promise. "We were railroaded" (Sanders, 1986c, p. B3). Graham contends that Shore had agreed to introduce a resolution rescinding the sanctuary resolution, but backed out at the last minute. Shore said he decided against proposing a compromise resolution, because it did not have the support of a majority of the council. The decree he considered introducing would have rescinded sanctuary and replaced it with a resolution asking for reform of U.S. immigration policy (Sanders, 1986a\&b). Speaking about the city's existing resolution, Shore said, "[It] is a symbolic resolution and I hate to see us get in a major fight over it”'(Sanders, 1986c, p. B3) Later, Shore told reporters that he supports political asylum not only for Guatemalans and Salvadorans, but other refugees as well (Sanders, 1986c).

In mid-September 1986, frustrated sanctuary foes held a press conference outside the state Capital where the coalition launched its petition drive to overturn Sacramento's “open-arms" resolution. In the news interview, Helen Graham called the council's legislative actions irresponsible. "I think it hinges on anarchy," she said (Sanders, 1986b, p. B1). The group's initiative would propose that Sacramento not be a sanctuary for people living there illegally. But Mayor Rudin was not worried. "My sense is there's a 
great deal of support for Sacramento to be a sanctuary city," she said. "No one has been able to show that the policy has done harm to the city" (Sanders, 1986b, p. B1).

A few days later, U.S. Attorney Peter Nowinski, chief prosecutor for the U.S. Department of Justice, asked the Council to repeal its sanctuary resolution. Concerns about the declaration misleading immigrants, and subverting asylum procedures established by Congress, compelled him to act. The chief prosecutor made his request in a four-page letter sent to council members. "I would like to remind you that your oath of office requires you to uphold the laws of the United States," he wrote (Sanders, 1986a, p. B3). City Attorney James P. Jackson said the resolution did not violate any state, federal or local law. Nowinski closed his letter by saying, "[sanctuary] is irreconcilable with continued federal assistance to Sacramento law enforcement and other programs" (Sanders 1986a, p. B3). However, Nowinski's closing statement was invalidated in a later interview when he revealed he had no power to withhold funds, and was not aware of a legal precedent to support his position (Sanders, 1986a).

Councilman Joe Serna reacted angrily to the letter. He accused Nowinski of trying to blackmail the city of Sacramento for disagreeing with the unfair application of federal refugee policy (Sanders, 1986a). Mayor Rudin called Nowinski's letter an attempt to intimidate the city. "I'm not intimidated," she told the Sacramento Bee (Sanders, 1986c, p. B3). Council members notified reporters there was little chance the sanctuary resolution would be rescinded unless the federal government withheld funds, or the issue qualified for a city ballot, which it did not (Sanders, 1986c). 
The next month (October 1986), anti-illegal immigrant activists launched a petition drive to revoke the city's sanctuary resolution. Roger Canfield, president of the local chapter of the Conservative Citizens for America, spoke during the brief ceremony in front of City Hall. He said Sacramento, which he referred to as the Democratic People's Republic of "Rudingrad" and "Ciudad de Serna," had adopted a "sinister" policy which limited sanctuary to refugees who attacked U.S. Central American policies (Perkins, 1986, p. B1). ${ }^{126}$ When a journalist asked Canfield whether his terms, "Rudingrad" and "Ciudad de Serna," could be considered bigoted or racist, Canfield replied: "It was a colorful way of dramatizing how a few can make their mark on the city in a negative way" (Perkins, 1986, p. B1). He was referring to the support given the resolution by Mayor Anne Rudin and Councilman Joe Serna Jr. Canfield's group was part of a coalition attempting to collect signatures to put the sanctuary issue on the September 1987 ballot. The County Taxpayers League Inc., Veterans of Foreign Wars, American Legion, American Prisoners of War, Paul Gann's People's Advocates, and Californians for Population Stability, also participated in the petition drive (Perkins, 1986; Berstein, 1987).

Ten months after adopting its "sanctuary city" resolution, the City Council asked the city-county Human Rights and Fair Housing Commission (HRFHC) to assess its impact on Sacramento. In February 1987, the task force sent a report to the city council. "There is no indication of an increase of undocumented El Salvadorans or Guatemalans

\footnotetext{
${ }^{126}$ Canfield said he used the term 'Rudingrad,' because Mayor Rudin has traveled to the East bloc, and "Ciudad de Serna" ('Cerna's City' in Spanish), because it described the long heritage of Spanish in California (Perkins, 1986).
} 
in the Sacramento area since the passage of the council's resolution," the report said (Lindelof, 1987, p. B1). Researchers also found little or no evidence that undocumented Salvadorans or Guatemalans were using federally funded programs such as Medi-Cal or job training programs. This data contradicted assertions made by members of Californians for Immigration Reform and David N. Ilchert, the San Francisco district director of the U.S. Immigration and Naturalization Service (INS). Both claimed undocumented immigrants had been found with translated news clippings of Sacramento's sanctuary status (Lindsey, 1985; Perkins, 1986). Harold Ezell, the Western district director of the INS, endorsed the idea that sanctuary resolutions had stimulated new flows of immigrants from Central America. Smugglers of aliens are using cities' sanctuary resolutions to recruit prospects south of the border, he explained to a local journalist (Wilson, 1986). On this point, the HRFHC report quoted Anne Kanter, an attorney who handles immigration cases. She said undocumented workers most likely "follow relatives and friends to a geographic area and not City Council resolutions" (Lindelof, 1987, p. B1).

A month later (March 1987) critics of the Sacramento's sanctuary policy claimed the review issued by the city-county Human Rights and Fair Housing Commission was flawed. Speaking at a press conference attended by one reporter, members of the Coalition for Immigration Reform called the report "incomplete" and its conclusion "predetermined" (Bernstein, 1987, p. B3). Helen Graham, a lobbyist for Californians for Population Stabilization, criticized the report for only looking at a 60-day period to compare the number of Salvadorans and Guatemalans apprehended by the Border Patrol's 
Sacramento district (Bernstein, 1987). Using statistics from San Diego (that the Border Patrol apprehended twice as many Salvadorans and Guatemalans crossing the Mexican border last year as the year before) Graham claimed it was safe to assume that undocumented immigrants who got past authorities were attracted to Sacramento because of the city's sanctuary policy (Bernstein, 1987). The City Council got what they wanted to hear, she argued, because they paid for the report. Randy Shiroi, who wrote the report for the city-county commission, denied that the conclusions were preordained. "There have been many instances where we have opposed the city," he told a writer for the Sacramento Bee (Bernstein, 1987, p. B3). According to the Bee, annual statistics provided by the Border Patrol supported the report's conclusion (Bernstein, 1987). ${ }^{127}$

In April 1987, Californians for Immigration Reform fell short in their drive to place the sanctuary issue before city voters. They failed to obtain the necessary 18,327 signatures - 10 percent of registered voters - to qualify for the ballot. Councilman Joe Serna said he was not surprised that opponents failed in their petition drive (Sander, 1987b). "I think the people of the city—and Americans, generally—support political asylum because we all come from immigrant backgrounds," he said in a press interview. "It's symbolism. But it's important that we stand up on these issues" (Sanders, 1987b, p. B1).

After a six-year legal battle, a U. S. District Judge approved a settlement agreement between the U.S. Immigration and Naturalization Service and more than 70 churches and human rights groups. The 1990 agreement granted temporary protected

\footnotetext{
${ }^{127}$ Glen Smith, acting chief patrol agent, said the number of apprehensions of illegal Guatemalans and Salvadorans declined from 40 in fiscal year 1985 (Oct. 1, 1984 to Sept. 30, 1985) to 28 in fiscal year 1986 (Bernstein, 1987).
} 
status to some 230,000 Salvadorans and Guatemalans, and directed the INS to reconsider their petitions for asylum (Bee, 1991; Meyers, 2004).

\section{Amnesty for unauthorized immigrants}

Councilman David Shore delivered a scroll to INS officials in Sacramento proclaiming March 19, 1988 “Amnesty Day” in the city (Sanchez, 1988). The

Sacramento City Council approved the resolution to publicize the amnesty features of the new Immigration Reform and Control Act of 1986 (Sanchez ,1988). ${ }^{128}$ To recruit applicants, the agency most feared by unauthorized immigrants launched its own publicity campaign. The INS' public relations blitz emphasized the benefits of citizenship and tried to dispel myths about the amnesty program being a sting operation. Despite fears, between 1987 and 1988, 8,449 people applied for amnesty at the INS "legalization office" in Sacramento (Sanchez, 1989). ${ }^{129}$ The publicity encouraged noncitizen legal residents to come forward too. Federal judges granted citizenship to 5,147 legal immigrants in 1988, nearly double the number in 1987 (2,640) (Sanchez, 1989).

The exploding client load and a shortage of clerks caused staff at the INS office in Sacramento to fall behind, according to the agent in charge, Lionel M. Nurse. In the early 1990s, they had 10,000 unprocessed citizenship applications stacked up (Sanchez, 1992). By 1998, they were buried under a backlog of 40,000 citizenship applications and applicants were waiting three years for naturalization interviews (Breton, 1998; Sanchez, 2002). A combination of factors led to the mid-1990 surge in INS applications, which

\footnotetext{
${ }^{128}$ Under the Immigration Reform and Control Act of 1986, illegal immigrants who had lived in the United States continuously since January 1, 1982 were granted legal resident status, along with a quota of unauthorized agricultural laborers.

${ }^{129}$ The agency set up a local "legalization office" to process legal-resident claims. 
eventually forced a wrenching overhaul of the citizenship system, further exacerbating delays. $^{130}$

First, a new amnesty law passed that gave certain Nicaraguan, Cuban, Salvadoran, and Guatemalan asylees (and their dependents) a chance to become legal permanent U.S. residents. ${ }^{131}$ At the same time, immigrants who gained their green cards through the 1985 amnesty program were becoming eligible for citizenship. Finally, the anti-illegal immigrant sentiment behind Proposition 187 prompted legal immigrants to seek citizenship (Sanchez, 1995). A desire to vote against future anti-immigrant measures motivated many in the latter group to apply. "When you don't participate, politics happens to you," Mayor Serna reminded them ("Prop. 187," 1995, p. B8)

Sacramentans caught in waiting lines for green cards and citizenship complained to city leaders, because in 1986 officials passed a resolution vowing "to support efforts to encourage and facilitate naturalization in the Hispanic immigrant community."132 At the time, Hispanics had the lowest naturalization rates among Sacramento’s immigrant groups. Councilman Joe Serna Jr. spoke on behalf of the resolution, which was recommended by city staff. The Sacramento City Council voted unanimously in favor of the citizenship measure, and Mayor Anne Rudin signed it.

\footnotetext{
${ }^{130}$ In 1997, the INS came under fire for naturalizing 180,000 immigrants without completing criminal background checks. A Justice Department audit found 16,400 had felony records. Congressional Republicans forced a slowdown of citizenship procedures.

${ }_{131}$ Pub L.105-100, Section 203 of the Nicaraguan Adjustment and Central American Relief Act of 1997.

${ }^{132}$ Resolution No. 86-512: Resolution for Promoting American Citizenship in Sacramento's Latino Community (July 1, 1986).
} 
Citizens-in-waiting reminded local officials about this promise. They said the hostile immigrant environment in Sacramento made them feel unsafe. Between July and October 1993, a self-proclaimed white separatist firebombed the local National Association of Colored People's (NAACP) office, the Japanese American Citizens League, a synagogue, the home of City Councilman Jimmie Yee and the state Office of the Fair Housing and Employment in Sacramento. Swastikas were also painted on an African American bookstore (Bancroft, 1993; Magagnini, 1993). Mayor Serna linked the hate crimes to Governor Pete Wilson and other public officials who blamed undocumented immigrants for California's problems. "At a time when we need to bring people together, political leaders seem to be insistent on dividing us for purposes of campaign tactics," he said in a press interview (Bancroft, 1993, p. B2).

Serna promised an anxious crowd of 400 at a local NAACP membership banquet that he was committed to the prompt arrest and appropriate punishment of the perpetrators. ${ }^{133}$ His speech began with an overview of the historic link between racism and tough economic times in California, and concluded with a confirmation of the current situation:

As people of color, you and I have to work twice as hard to get half as far to get where we are, and we accept that...[the term] 'reverse discrimination' [is] an oxymoron, because we have never made the rules (Magagnini, 1993, p. B1).

When Americans pledge liberty and justice for all, he preached, "it means liberty and justice for all not someday—now!” (Magagnini, 1993, p. B1). The mayor pledged to counteract negative publicity from the bombings, and closed by saying "We are a community that is unified. What you have now is an outlaw" (Bancroft, 1993, p. B2).

${ }^{133}$ African American, Asian American, Jewish and Latino community leaders attended the event. 
In October 1993, the Sacramento City Council adopted a resolution condemning the hate crimes and reaffirming its commitment to eliminate them. ${ }^{134}$ The following year, the city established a multiagency hate crime task force (Bureau of Justice Assistance, 1993)..$^{135}$

In August 1996, Sacramento radio talk-show host, Jeff Katz, made incendiary remarks about "illegals" that ignited a firestorm of protest. He said motorists should be awarded a sombrero-shaped bumper sticker for every illegal immigrant hit while attempting to cross the border from Mexico. The bumper stickers would earn motorists a free meal or drink at Taco Bell (Bizjak, 1996; Bizjak \& Vierra, 1996). When he heard about the incident, Serna angrily exclaimed:

This is an advocacy for violence. This is a hate crime. You have a talk show host advocating murder. What I want is Jeff Katz's resignation. I don't want his apology. I want him off the air (Bizjak, 1996, p. B1).

The next night more than 200 angry people jammed into City Hall for the council's regular meeting. Mayor Serna asked members of the community to come forward to speak about the remarks made by Mr. Katz. Councilman Steinberg called Katz's remarks "sick and reprehensible" (Burrowes, 1996, p. 4). Those who hold the public airwaves need to act responsibly, he added. Councilwoman Heather Fargo stated that she would like Mr. Katz to apologize for his statements. His "remarks posed a clear and present danger," Council member Debra Ortiz exclaimed (Burrowes, 1996, p. 4). Other speakers

\footnotetext{
${ }^{134}$ Resolution No. 93-566 (October 12, 1992).

${ }^{135}$ The Greater Sacramento Area Task Force on Hate Crime, sponsored and administered by the United States Attorney's Office, consists of federal, state, and local law enforcement agencies and community organizations dedicated to preventing and combating hate crimes including the FBI, the ATF, the Sacramento County District Attorney's Office, Sacramento Office of the City Mayor, the Sacramento Sheriff's Department and Police Department, Sacramento Human Rights Fair Housing Commission, the NAACP, the Anti-Defamation League, and more (U.S. Department of Justice, n.d.).
} 
at the council meeting emphasized the potential for violence as well. "All it takes is one individual to...terrorize this community,” said Deputy Police Chief Al Nájera, recalling the hate crime wave carried out by a 17 -year-old in Sacramento several years earlier (Bizjak, 1996, p. B1).

Among those who spoke against the alleged comments made by Jeff Katz were representatives from these organizations: the Mexican Consulate, Hispanic Chamber of Commerce, Jewish Community Relations Council, Japanese American Citizens League, Mexican American Legal Defense and Educational Fund, Raza Lawyers Association, NAACP, Sacramento Black Chamber of Commerce, Human Rights Commission, Sacramento Police Department, and others (Burrowes, 1996). Rick Eytheson, representing the radio station KSTE, said he had not heard the broadcast but if press reports were accurate, then Mr. Katz's remarks were "reprehensible" (Burrowes, 1996, p. 4). He promised to take appropriate action after he heard the broadcast tape.

Mayor Serna and the eight-member City Council responded to public outrage by uniformly denouncing Katz and the radio station. Joe Serena called for his resignation. Nine days later Mr. Katz was relieved of his job at Talk 650 (Bizjak \& Vierrria, 1996; Otani, 1996). Still the anti-illegal immigrant rhetoric scared Sacramentans without U.S. citizenship. They pressured city leaders to do something to speed up INS processing times. 
During a 1998 Race Initiative Outreach Meeting at the White House, Mayor Serna asked President Clinton to use his executive authority to remedy the backlog problem. ${ }^{136}$ Here is Serna's appeal:

I think a lot of folks that come from Mexico or that come from other parts of Latin America are waiting to be told, we appreciate you being here and we'll do everything to assist you in becoming Americans. So I would encourage you, Mr. President, to do what you can to encourage the INS to process folks thoroughly, quickly, and then sponsor a citizenship program (The White House, 1998, p. 6).

In California, the backlog problem has resulted in the "scapegoating of immigrants, which is incredibly divisive in the state," Mayor Serna added (The White House, 1998, p. 5). The President acknowledged the INS processing problem, saying:

You know, when I came here, it was taking an unconscionable long time for people to get through the system, and we tried to accelerate it. And the Congress had such a negative reaction to it, the Republican majority did, they tried to investigate the whole INS because we took the position that you shouldn't have to wait years and years after you had already been here five years, to have the government decide whether you could become a citizen or not. I still think that's the right thing to do. I think it's entirely too bureaucratic, and I think we should do better (The White House, 1998, p. 6).

In 1999, the INS launched an initiative to reduce citizenship processing time. That was not soon enough for immigrants terrorized by hate crime. In June, three local synagogues were targeted in pre-dawn arson attacks (U.S. Department of Justice, n.d.).

The next day, some 4,000 people stood under a giant "Sacramento United Against Hate" banner in response to the coordinated firebombing (Tugend, 1999). Committed to fight bigotry, more than 2,500 people jammed into a community center, while 1,500 listened in an overflow auditorium, for a two hour rally (Tugend, 1999). Mayor Joe Serna said, "When I hear of synagogues burning, then I am a Jew" (Tugend, 1999, p. 5).

${ }^{136}$ Serna was part of the Initiative's seven-member Advisory Board. 
Abraham Foxman, national director of the Anti-Defamation League, declared that Sacramento would be held up as a model of how a community must respond to bigotry (Tugend, 1999). During a smaller noon rally across from a damaged synagogue, Vice Mayor Jimmie Yee, whose home was firebombed in 1993, urged the crowd to display "Sacramento Together, United We Stand" signs in their homes, businesses and cars (Tugend, 1999). Joe Serna Jr. died later that year. The mayoral torch was passed from a former Chicano farm worker to a former Chinese American day laborer-Jimmie Yee (Weaver, 1999). ${ }^{137}$

In 2000, the INS declared victory over its citizenship backlog crisis. With several amnesty measures pending in Congress (a sign anti-immigrant sentiment had waned), a local drive for a general pardon put the issue back on the municipal agenda. In September, about 4,000 marched through the streets of Sacramento calling for amnesty for the city's unauthorized residents. Sacramento mayoral candidates Heather Fargo and Rob Kerth, and Councilman David Jones, spoke in support of amnesty at the rally to kick-off the march. The Sacramento Valley Organizing Community, a local coalition of about 35 African American and Latino churches, organized the rally and march with support from local labor and legal communities. ${ }^{138}$ As marchers passed the INS offices on the Capital Mall, they deposited photos of people who had applied for residency or citizenship. Afterwards, a petition in favor of amnesty was sent to President Clinton and Congress (Chávez, 2000; Martineau, 2000).

\footnotetext{
${ }^{137}$ Shortly after winning his third term, Vice Mayor Yee was appointed mayor by the City Council to fill the unexpired term of Joe Serna Jr., one week after Serna's death on December 14, 1999 until November 27, 2000 when new mayor Heather Fargo was sworn in.

${ }^{138}$ Earlier the AFL-CIO, in a stunning change of heart, voted to seek amnesty for all working unauthorized immigrants and to push for the elimination of employer sanctions it helped enact (Chávez, 2000).
} 
In March 2006, more demonstrations on behalf of non-U.S. citizens took place in Sacramento. Latino activists held a small protest against the federal bill (H.R. 4437) that would make illegal immigration, or offering aid to the undocumented, a felony. ${ }^{139}$ The Chicano Consortium organized the event (Ferriss, 2006a). The legislation was the catalyst for a second round of protests in May (Robertson \& Camerini, 2010). According to news accounts, it was one of largest demonstrations in Sacramento in recent memory. Police estimated that between 15,000 and 18,000 demonstrators massed at the state Capital then marched downtown as part of the nationwide work stoppage called "A Day Without Immigrants." Organizers claimed 36,000 to 40,000 protested. Only a handful of counter-demonstrators showed up (Ferriss, 2006b; Korber, 2006). Sacramento's new mayor, Heather Fargo, did not take a public stand on the issue; neither did the city council. ${ }^{140}$

In October 2009, as Congress prepared to take up immigration reform again, Sacramento Police Chief Rick Braziel said it was time to legalize millions of undocumented immigrants. Braziel, made the appeal for immigration reform as part of the Law Enforcement Engagement Initiative (LEEI) (Ferriss \& Magagnini, 2009). ${ }^{141}$ In a telephonic press conference organized by LEEI, which included several other big-city police chiefs, Braziel made this statement:

\footnotetext{
${ }^{139}$ Border Protection, Anti-terrorism and Illegal Immigration Control Act of 2005 (H. R. 4437).

${ }^{140}$ Fargo, a former City Council member, was sworn in as Mayor in November 2000, replacing Jimmie Yee, and served until December 2008, when she was replaced by Kevin Johnson. Heather Fargo, who is European American, grew up in Davis, Santa Maria, and Stockton, CA.

${ }^{141}$ LEEI is an organization founded by former Sacramento Police Chief Arturo Venegas Jr. to give police a voice in the immigration debate.
} 
Our city is one of the most diverse and integrated in America. We celebrate our cultural heritage and differences and strive to be inclusive. We can't afford to have a group of residents be afraid of reporting crime because they believe we may report them for deportation. To allow fear to exist in the minds of victims or witnesses endangers them and the rest of the community and lets criminals off the hook. Without comprehensive immigration reform, we place our communities and our nation at risk. It is time for Congress to take action on immigration reform to increase public safety and encourage full civic participation from all members of our community ("Police Leaders," 2009, para. 3)

In a later press interview, Braziel said a common-sense apolitical approach was needed to fix what he called an unworkable immigration system. He favors a twopronged solution: tighter borders and a way to allow undocumented immigrants who are productive stay in the U.S. legally. Now, fear of being deported is putting the public at risk, Braziel added (Magagnini \& Ferriss, 2009). "We need to remember that there are at least 12 million people out there who are unauthorized to be in this country, and they're our neighbors," Braziel told reporters (Magagnini \& Ferriss, 2009, p. B1). It is not feasible to deport millions of undocumented immigrants, Braziel and other police chiefs from cities with large immigrant populations, pointed out (Cave, 2009). To which one anonymous Sacramento Bee blogger wrote "Fire him!"” (Brenton, 2009).

\section{The devolution of immigration law enforcement}

On October 5, 1993, California Governor Pete Wilson signed four bills aimed at denying benefits to undocumented immigrants. One of those measures attempted to overturn local immigration sanctuary. ${ }^{142}$ The law prohibits cities and counties from passing "sanctuary" laws that prevent local law enforcement agencies from cooperating with immigration authorities (“California Laws,” 1993; Chávez, 1993). Still local officials did not rescind Sacramento's “don't ask, don't tell” policy, a practice initiated

${ }^{142}$ SB 691 by Sen. Quentin Kopp, I-San Francisco. 
after adoption of the "sanctuary city" resolution. The unbinding directive, while it does not offer the accountability of a law or administrative regulation, is commonly adhered to. The city's governing body and local public servants, including police, uphold the principles outlined in the 1985 decree. Besides, formal laws are not needed when those in charge understand and can relate to immigrants.

By the time Wilson's law passed Sacramento had, for the first time in the city's history, a truly diverse city council (Kollars, 1992). It was also the largest_- perhaps only_ city in the country with a Latino mayor and police chief (Furillo, 1993a). Former city councilman Joe Serna Jr. was elected mayor in 1992 on a cultural unity platform, and re-elected in $1996 .{ }^{143}$ He was the first minority in Sacramento to hold that position. The bilingual college professor was raised in labor camps near Lodi, California, where he picked grapes and tomatoes as a youngster to support his poor Mexican immigrant family (“Immigrant Mayors," 1999; Sanchez, 1999). As mayor, Serna put up a UFW flag in his office and renamed the park downtown Cesar Chavez Plaza (Bizjak \& Kollars, 1999). It was Serna who introduced the "sanctuary city" resolution to the Sacramento City Council; subsequent elected officials have upheld it.

Sacramento hired its first minority police chief, Arturo Venegas Jr., in January 1993. Venegas was born in a house with a dirt floor in San Nicolas de Ibarra, Jalisco, Mexico. Community reaction to Venegas' selection was overwhelmingly positive. He pledged to improve minority hiring in the police department, ${ }^{144}$ and make developing a

\footnotetext{
${ }^{143}$ Joe Serna J. was elected to the city council in 1981, where he served 11 years (Bizjak \& Kollars, 1999).

${ }^{144}$ Only one member of the department's command group was a non-white when Chief Venegas arrived. Before he retired 17 were people of color. Venegas' efforts to diversify the SPD resulted in the loss of a 1999 reverse discrimination lawsuit (Bizjak, 2002).
} 
"police-public partnership" a top priority (Furillo, 1993b). Chief Venegas, whose tenyear tenure was double the national average for chiefs of police (Bizjak, 2002), founded the Law Enforcement Engagement Initiative (LEEI) after he retired. LEEI provides a platform for law enforcement professionals to add their expertise to the dialogue about common-sense immigration reform (Solís, 2009).

Chief Venegas is adamantly opposed to police enforcement of civil immigration law, or helping federal agents to do the same. When bans on sharing information with the federal government were outlawed in 1996 by the Illegal Immigration Reform and Immigrant Responsibility Act (IIRIRA), Chief Venegas did not alter local police conventions. Officers, then and now, do not quiz people about their immigration status during traffic stops, while investigating minor infractions, or when someone is a witness or victim of a crime. Venegas also rejected federal efforts to encourage department involvement in the $287(\mathrm{~g})$ program, which gives officers a role in deporting unauthorized immigrants. ${ }^{145}$

Sacramento police do, however, work with Immigration and Custom Enforcement (ICE) in multijurisdictional crimes forces. In 1998, the Sacramento Police Department joined the FBI-led Joint Terrorism Task Force (Federal Bureau of Investigation, n.d.). The partnership generated little controversy or fanfare (Davila, 2003). ${ }^{146}$ Sacramento police also coordinate with ICE to apprehend and detain undocumented immigrants suspected of serious crimes. Deputies at the county-run jail, which police use, have been

\footnotetext{
${ }^{145}$ Police departments that sign $287(\mathrm{~g})$ agreements designate officers to be trained and authorized to detect and detain immigration offenders that they encounter during their regular, daily law enforcement activity. ${ }^{146}$ Amended Resolution No. 2003-046 (adopted February 6, 2003); Amended Resolution No. 2003-047 (adopted February 6, 2003).
} 
reporting arrested unauthorized aliens to the INS since 1993. The reporting requirement is a condition of receiving federal law enforcement grants (Coronado, 1993).

Venegas’ predecessors—Chief Albert Nájera (2003-2008) and Chief Rick Braziel (2008-present)--shared Venegas' outlook on police involvement in immigration enforcement. After the September 11, 2001 attacks on the World Trade Center and Pentagon, Chief Nájera resisted mounting pressure to involve police in the enforcement of civil immigration laws. He explained the philosophy behind his dissent this way: "We can't afford to have victims out there who won't call us because they're afraid they're going to be deported," Nájera revealed during a press interview. "People need to be able to call the police and have trust in us, without regard to their immigration status" (Bazar, 2004b, p. A1). The Chief opted out of the ICE 287(g) program because he believes turning local officers into de facto immigration agents is not good for crime fighting (“Immigration Law," 2004).

Sacramento's current police chief, Rick Braziel, like those before him, rejected federal efforts to involve police in the enforcement of noncriminal infractions of immigration law. In an interview with the Sacramento Bee, Braziel revealed that he has met personally with Latino leaders and said, "Here's the deal, we're not going to check immigration status - tell your communities not to be afraid to work with us" (Magagnini \& Ferriss, 2009, p. B2). The Chef has openly criticized the federal 287(g) program and lobbied Congress to separate local police from immigration enforcement (Taylor, 2007; Cave, 2009). He joined other chiefs across the United States in calling for immigration reforms that would legalize millions of undocumented immigrants. "The public's safety 
depends on it," Braziel explained (Magagnini \& Ferriss, 2009, p. B2). ${ }^{147}$ Generally, immigrant communities are more likely to report crime to police, testify at trial, and cooperate with local law enforcement if local law enforcement is not seen as part of immigration enforcement.

Sacramento police are not the only ones opposed to singling out foreigners for civil immigration violations. In November 2003, the Sacramento City Council voted 8-1 to adopt a resolution opposing the infringement of civil liberties by the federal government; Mayor Heather Fargo signed it (Bazar, 2003c\&d; Stanton \& Bazar, 2003). ${ }^{148}$

The decree "calls on agencies and employees of the City not to engage in any activities that would violate any city ordinance or the laws and constitution of the State of California or of the United States." It "reaffirms the Sacramento Police Department's commitment to unbiased policing and endorses the principle that no law enforcement or other city agency may profile or discriminate." 149 The resolution further urges federal officials to repeal provisions of the Patriot Act that infringe upon the rights and liberties of the Sacramento residents, particularly people of Arab descent, Muslims, immigrants

\footnotetext{
${ }^{147}$ Braziel made his call for immigration reform as part of the Law Enforcement Engagement Initiative, an organization founded by former Sacramento Police Chief Arturo Venegas Jr. to give police a voice in the immigration debate.

${ }^{148}$ Resolution No. 2003-795 (November 13, 2003). The State of California passed a similar resolution in 2006 (BORDC, 2006).

${ }^{149}$ The resolution also directs Sacramento public school officials to notify individuals whose education records have been obtained by law enforcement agents under the Patriot Act, and directs Sacramento public libraries to post signs warning patrons that their reading habits and Internet browsing may be scrutinized by federal agents.
} 
and dissidents. In signing the resolution city leaders reiterated their commitment "to protect the rights of immigrants and opposes measures that single out individuals for legal scrutiny based on their country of origin, religion, or immigration status."

The document's purpose and underlying philosophy are explained in its preamble, which highlights the city's pride in its "reputation as the most integrated city in the United States and a model of tolerance for the state and the nation." It also acknowledges the contributions of the city's diverse population of immigrants, students, farm workers, and others who are vital to its "economy, culture, and civic character," and whose civil liberties should be preserved for the political and social health of the community. Even though the resolution does not carry the weight of law, it will guide the behavior of city employees by serving as a statement of policy, said lawyer Keith Wagner, a member of the Sacramento Coalition to Stop the Patriot Act (Bazar, 2003d). ${ }^{150}$

Here's how the resolution came to be. In January 2003, about 100 demonstrators gathered at a rally and press conference outside Sacramento's Immigration and Naturalization Service office on the Capital Mall (Bazar, 2003a\&b). The protestors called for the elimination of a special INS registration program that they said unfairly targets Middle Eastern and Muslim men, and contend is a form a racial profiling (Bazar, 2003c). The protest attracted peace activists, immigration attorneys and representatives from local cultural groups, (Bazar, 2003a\&b). In addition to the American-Arab Anti-Discrimination Committee (ADC), representatives from Japanese, Chinese, Latino, Middle Eastern and

\footnotetext{
150 "Where requirements are made for cooperation or turning over of information under the Patriot Act, it gives those city workers the ability to hold off and seek a second opinion on whether what they're being asked to do is consistent with state and federal constitutional principles," he said (Bazar, 2003d).
} 
Muslim cultural organizations attended the protest (Bazar, 2003a). Many immigrant groups organized out of fear that the registration program would be expanded to include their own communities. After the rally they coalesced into the Sacramento Coalition Against the Patriot Act (Stanton \& Bazar, 2003a).

In July the group organized a meeting to drum up support for a city council resolution condemning the controversial anti-terror law. More than 250 people jammed into the downtown meeting room to hear speakers denounce the Bush administration's secret surveillance, arrest, and detention of "disfavored classes of immigrants" (Stanton \& Bazar, 2003a). Recounting how U.S. Attorney General John Ashcroft sought police help in keeping tabs on visa overstayers (a civil immigration violation), former Sacramento Police Chief Arturo Venegas Jr. said, "I thought that was the most stupid thing anybody could ever ask us to do" (Stanton \& Bazar, 2003a, p. B1). He also warned that the Patriot Act "allows law enforcement now to be able to pry into your lives, to seek information on you and even to hold you incommunicado" (Stanton \& Bazar 2003a, B1). Venegas urged the crowd to press for a resolution condemning the law. No words of support for the Patriot Act were delivered during the two-hour session (Stanton \& Bazar 2003a).

The next week, U.S. Attorney John Ashcroft swept through Sacramento to talk up the Patriot Act and encourage federal workers, including police involved in Sacramento's anti-terrorism task force, to help federal agents (Stanton \& Bazar, 2003b). There were no demonstrators outside the federal building where Ashcroft spoke. Details of his visit were not publicized in advance (Stanton \& Bazar, 2003b). "Even if it wasn't open to the 
public, the public should have been aware that he was here speaking to law enforcement about issues that relate to people's lives, particularly in the immigrant community," said Carl Pinkston, who arranged last week's anti-Patriot Act meeting in Sacramento (Stanton \& Bazar, 2003b, p. B1).

Frustrated coalition members showed up in force at the November 13, 2003 city council meeting, to hear debate on the proposed civil liberties measure. More than 100 people crowded into council chambers, and another 100 lined up outside hoping to get in (Bacher, 2003b). Arguing in favor of the resolution was a coalition that included the League of Women's Voters of Sacramento (LWVS), NAACP, ACLU, Physicians for Social Responsibility, American Library Association, various Asian, Hispanic, Jewish, Islamic organizations and other religious and human rights groups (ACLU, 2003; Bettis, 2003).

The second-ranking official in the U.S. attorney's office in Sacramento, Larry Brown, spoke ten minutes against the resolution (ACLU, 2003; Stanton \& Bazar, 2003c). Activist Dave Jenest, who founded a group called the Patriot Defenders Network, argued the city has no business making statements about federal security issues. "I think it's stupid," he said. "I think it's, 'Me too.' Let's go join 130 other places that oppose the Patriot Act" (Bazar, 2003d, p. A1). City staff drafted the resolution (Stanton \& Bazar, 2003c).

About 60 community members were scheduled to speak at the city council hearing. After 30 activists had spoken the debate was cut short when Councilman Jimmie Yee announced he was ready to vote (Bacher, 2003b). “I don't need another 30 people to 
tell me what they think about this," he said. "I'm ready to support it. I don't know how much more it takes" (ACLU, 2003, para. 3). Yee's comments brought loud applause from the audience (Bacher, 2003b). Then, Mayor Heather Fargo addressed the crowd:

I was moved by your testimony, not only by the words but by the breadth of community groups represented here tonight. People here tonight have shown that they are not just concerned about the civil rights of themselves, but the rights of others (Bacher, 2003b, para. 2).

The vast outpouring of support for the resolution prior to and during the meeting moved council members to vote in favor of the resolution.

Afterward the meeting, both Councilwomen Lauren Hammond (who introduced the measure) and Councilman Dave Jones (an early supporter) said that opposing the unconstitutional provisions of the Patriot Act was the patriotic thing to do (Bacher, 2003b). They were taking a stand on a civil rights issue. "We have as much at stake in this as anybody. Maybe more, given the size of our various ethnic and minority communities, the diversity of this community and the importance we place on diversity in Sacramento," Councilman Jones told the Sacramento Bee (Stanton \& Bazar, 2003c, p. B1).

Given Sacramento's propensity for broad civil rights protections, the city's response to Arizona's controversial new immigration law was not too surprising; although its convoluted approach was a bit unusual. Five days after Arizona's Governor Jan Brewer triggered a national firestorm by signing the nation's toughest illegal immigration bill, Sacramento's new mayor, Kevin Johnson, responded. He wrote on his website's blog that the city should follow the lead of others and sever economic ties with Arizona (Breton, 2010a; Lillis, 2010a). But later that day, Johnson changed his mind and 
wrote: "Damaging the good work of Mayor Gordon and the many honorable people in his city in retribution for the immigration law can become the equivalent of trying to make two wrongs equal one right” (Smith, 2010, para. 9).

Critics claim he caved to pressure from Phoenix--where Mayor Johnson starred as a point guard with the Suns basketball team for 12 seasons and got campaign contributions (Reese, 2010). "Would Johnson have caved if Arizona targeted African Americans?" a columnist for the Bee speculated (Breton, 2010a, p. B1). Kevin Johnson is the first African American to hold the position of mayor in Sacramento.

When asked why he switched positions, Johnson said that Phoenix Mayor Phil Gordan convinced him that sanctions would hurt the battered economy of that city. Still the new law would encourage "discretionary bigotry," and Arizona needs to be sent a message, Johnson added (Lillis, 2010a, B1). "This is a personal issue for me, a fundamental issue of justice for a place where I used to live for 12 years," the Mayor recalled (Lillis, 2010a, p. B1). The Arizona law is an example of going backwards, Johnson told the Bee. "This took me back to my time in Phoenix and I remembered how divisive [the King Holiday debate] was," he recounted. ${ }^{151}$ "I want to do what I can do, find a balance and send a strong message" (Lillis, 2010a, p.B1). So instead of conferring with his own city council, Johnson flew to Phoenix to discuss what he called an "unAmerican" and "morally wrong" law with elected officials in that city (Lillis, 2010a, p. B1). That was in April.

\footnotetext{
${ }^{151}$ In 1987 then-Arizona Gov. Evan Mecham rescinded Martin Luther King Jr. Day.
} 
On May 11, hundreds of demonstrators gathered in front of the State Capital building in Sacramento to denounce Arizona's new law, and convey urgency for action on comprehensive immigration reform (Caprio, 2010). Protestors demanded that the Sacramento City Council pass a resolution calling for a boycott of Arizona. Members of the Labor Council for Latin American Advancement, Council on American Islamic Relations, Japanese American League and Union Civica Primero de Mayo spoke at a news conference outside City Hall later that day (Lillis, 2010b).

On May 25, council members debated the law and how the city should respond. Mayor Kevin Johnson introduced the discussion with his personal insights and opinions: "[some people] do not think the city of Sacramento, should be talking about this issue. I respectfully disagree with that" (Lillis, 2010d, p. B1). An unjust law anywhere threatens our justice here locally, Johnson added (Lillis, 2010b).

Councilman Rob Fong agreed. It was he who asked that the issue be placed on the council agenda. Fong argued that it was the city's responsibility to be heard on what he called a "misguided and ill-conceived law" (Lillis, 2010e, para. 3). He asked his council colleagues to join him in directing city staff to draft a resolution condemning the law and instituting a boycott like other cities. "We have an obligation for our voices to be heard," he said. "If enough voices are heard, I believe we can get the law in Arizona repealed" (Lillis, 2010e, para. 5). Fong advocated taking "the most definitive position possible of opposition" (Lillis, 2010a, p. 4). Mayor Johnson replied, "Personally, for me, I think a boycott would be the thing to do" (Lillis, 2010c, para. 4). But he said the council should 
talk about it before the city takes a stand. He wanted to hear from the community too (Lillis, 2010c).

More than 230 people turned out for the public hearing. A rare overflow crowd began lining up an hour before the meeting (Haley, 2010). The City Council took comment from 70-80 people. Most of the speakers were in favor of the boycott, including former Sacramento Police Chief Arturo Venegas Jr., who called the law "the civil rights issue of today" (Lillis, 2010e, para. 8). "Will a boycott hurt Arizona?" Venegas asked the council. "Absolutely - that is the intent. However, the true intent is to repeal the racist law of Arizona" (Lillis, 2010e, para. 9). Venegas urged council members to sanction Arizona. Twenty-two speakers opposed the boycott, according to Mayor Johnson's count, (Haley, 2010a). They criticized the council for spending time on a law that had nothing to do with the residents of Sacramento (Haley, 2010a). The city should focus on its own issues, critics said, notably its $\$ 3$ million deficit. "You do this [boycott] to Arizona, we'll do it to Sacramento," said speaker Jim Ricketts (Lillis, 2010e, para. 11).

Elected officials brushed off the threat of a Sacramento boycott. Council member Sandy Sheedy called the law racist (Haley, 2010a). So did Councilwoman Lauren Hammond, who added, 'I'm the great grandchild of slaves, so you know what I'm going to say" (Haley, 2010a, para. 8). It's a "human rights issue," Johnson opinioned (Haley, 2010a, para. 7) Councilman Steve Cohn said the law was unconstitutional (Haley, 2010a). "This law makes an open season for racial profiling and harassment of people who look like maybe they don’t belong here” (Haley, 2010a, para. 10), Sheedy concluded. All eight of the council members present agreed to oppose the law, although 
Cohen and Councilman Ray Tretheway did not want to call for an economic boycott (Haley, 2010a). ${ }^{152}$

Councilors decided the city of Sacramento should oppose the law, and possibly boycott businesses in Arizona. City staff was charged with preparing a resolution defining the city's official position on the immigration law (Bisharat \& Teichert, 2010). The council planned to decide on the resolution the following week after hearing information about the city's existing ties with Arizona businesses (Haley, 2010a; Lillis, 2010d).

In the meantime, older Latino community leaders with familiar names and reputations quickly came together to push for a boycott. There was former Sacramento police chief Arturo Venegas, Arturo Aleman of the SEIU, Ralph Carmona, a former University of California regent and SMUD lobbyist, plus several Latino lawyers and the owner of the Spanish-language radio (Breton, 2010b). ${ }^{153}$ These activists did not picket or march, observed newspaper columnist Marcos Breton. They worked inside the system by lobbying council members and building diverse coalitions (Breton, 2010b). Even though there were no Latinos on the city council, the group was successful. Community members were at work even before Councilman Rob Fong put the Arizona boycott on the council agenda. To them, Arizona was violating the Fourth Amendment of the U.S. Constitution by empowering local cops to enforce federal immigration laws (Breton,

\footnotetext{
${ }^{152}$ Council member Robbie Waters was not at the meeting.

${ }^{153}$ SEUI is the acronym for the Service Employees International Union; SMUD stands for Sacramento Municipal Service District.
} 
2010b). Why seek a boycott? Breton asked. "For us not to speak would be immoral...We have to speak for those who can't speak for themselves," Luis Cespedes (an attorney) told the Bee journalist (Breton, 2010b, p. B1).

Hours before the Sacramento City Council was set to discuss how it should respond to the law, the ACLU of Sacramento County sent a letter to the council. The letter, sent on behalf of the organization's 2,600 local members, urged city leaders to adopt a resolution opposing Arizona SB 1070 (“ACLU of Sacramento,” 2010). The ACLU is proceeding with a lawsuit in Arizona that, among other points, states that the Arizona law is illegal, wrote Jim Updegraff, chair of the board of directors of the ACLU in Sacramento (“ACLU of Sacramento,” 2010).

In June 2010, the Sacramento City Council approved a resolution in protest of Arizona's tough new immigration regulations (S.B. 1070 and H.B. 1262) ${ }^{154}$ Those laws allow Arizona police to arrest people suspected of being unlawfully present in the United States, and to charge immigrants with a state crime for not carrying immigration documents. The vote passed 6-1, with Councilman Robbie Waters as the lone dissenter (Haley, 2010b). City staff drafted the resolution, which includes economic sanctions on Arizona and Arizona-headquartered businesses "until the disputed laws are repealed or nullified by a court." Opposition is expressed by prohibiting city workers from traveling to Arizona at city expense, boycotting future contracts to purchase goods or services with Arizona-based vendors, and terminating (if lawful) current contracts.

\footnotetext{
${ }^{154}$ Resolution No. 2010-346 (June 15, 2010).
} 
According to the decree, punitive measures were taken because S.B. 1070 and H.B. 1262 will lead to racial profiling and the intimidation of certain groups of people (local gardeners, nannies, home care workers), which could spread to everyone who looks Latino. They will also jeopardize public safety, and create distrust between law enforcement and ethnic communities. The resolution is meant to pressure Arizona to follow Sacramento's example of promoting ethnoracial equality and the elimination of bias. Sacramento's reputation as "the most 'diverse and integrated" city in the United States, and long tradition of supporting policies that prohibit discrimination, is highlighted in the measure. It also urges the President and Congress to "work on comprehensive immigration reform to fix our nation's immigration system." Councilman Waters summarized the arguments of opponents by stating that city business should come before intervention in another state's business (Fehr, 2010).

Two days later, a small crowd of 150 people rallied in front of City Hall to protest Sacramento's decision to boycott Arizona (Caprio, 2010a; Smith, 2010). Demonstrators called for a recall of Mayor Kevin Johnson and the City Council. ${ }^{155}$ "The city of Sacramento is a local city council and they should worry about local issues, not some state that they have no business being in," said rally organizer Paul Smith, a 5th Congressional District candidate (Smith, 2010, para. 3). The event consisted of speakers who echoed Smith.

\footnotetext{
${ }^{155}$ Targeted city council members include Mayor Kevin Johnson and city council members Ray Tretheway, Sandy Sheedy, Steve Cohn, Robert King Fong, Kevin McCarty and Bonnie Pannell. City council members Robbie Waters and Lauren Hammond are not targeted.
} 
Picking up on the crowd's discontent, Eric Hogue, Sacramento's last remaining conservative talk show host launched the website www.recallsacramento.com. ${ }^{156} \mathrm{He}$ constructed it to advance efforts to recall city officials. "If the people here in Sacramento can pick off one or two, maybe three city council members or start an active recall campaign...it sends a message," said Hogue (Caprio, 2010, para. 4 ). Arizona boycott opponents used the now defunct website to build a base for the recall. Smith said he was confident the group could get the signatures needed to force a recall election (Smith, 2010). Nationally-known Tea Party leader Mark Williams, a Sacramento resident, was a leader in the recall effort ("Recall of the Sacramento City Council," 2010).

According to Ballotpedia, the recall effort was abandoned in February. Still, the initiative inspired a "Boycott Sacramento" movement, which was launched through Facebook. ${ }^{157}$ The group, which supports SB 1070 and works to encourage the Sacramento City Council to rescind its Arizona boycott, had 3,117 "Friends" as of February 2012. A website created by former candidate for State Senate District 6, Gerald Klaas, contains a link to the Facebook page ("New Website," 2010).

Klaas' website, www.BoycottSacramento.com, urges the boycott of businesses within the Sacramento city limits in retaliation for the city council's economic sanctions against Arizona. The site's main page features this message:

\footnotetext{
${ }^{156}$ In 2000, Mayor Fargo called for the revocation of KSTE's broadcasting license after two morning talk radio hosts made offensive remarks about immigrants, homeless people and gays.

${ }^{157} \mathrm{http}: / /$ www.facebook.com/pages/Boycott-Sacramento-CA-for-Boycotting-Arizona/121430504556943.
} 
We believe that local and state governments should not initiate economic sanctions against fellow Americans, and to prove our point, we intend to fight fire with fire. Members of Boycott Sacramento have decided that the City of Sacramento is undeserving of our tax money, and so to prevent them from receiving their $.75 \%$ share of sales tax, we have decided to boycott businesses located within the city limits. It is unfortunate that many local businesses will be hurt in this showdown, but we didn't start this fight. Business owners should contact their city council members to express their dismay (Klass, n.d., para.1).

Klaas explained his motivation in a press release: "Since I don't live in the city, I can't vote to recall the idiots, so I'll do what it takes to keep my money out of city coffers" (Klass, 2010, p. 4). His website contains links to several related websites, including the Stand With Arizona (against illegal immigration) Facebook Page and an online retailer that produces "Boycott Sacramento" bumper stickers. Its "Recall the Sacramento City Council" link does not work.

\section{Government benefits for noncitizens}

In 1994, California citizens placed Proposition 187 on the ballot for voter approval. ${ }^{158}$ The initiative commonly known as "Save Our State" would exclude illegal immigrants from the provision of public education, publicly funded health care and social services. To accomplish this, all government funded agencies would be required to verify the legal residency of every applicant for education, health or social services, and report suspected unauthorized immigrants to state and federal authorities. ${ }^{159}$

\footnotetext{
${ }^{158}$ California Proposition 187 election results: Sacramento County - no 40.6\%, yes 59.4\%; Yolo County (West Sacramento - no 50.7\%, yes 49.3\%) from http://www.uselectionatlas.org.

${ }^{159}$ Prop. 187 also required all law enforcement agencies in the state to attempt to verify the legal status of every arrestee who is suspected of being in the United States illegally, and to inform and cooperate with the INS and State Attorney General.
} 
After hearing a report from the city's management analyst and deputy city attorney, the council voted unanimously in favor of a resolution opposing Proposition 187 on the November 8 ballot (Yost, 1994). ${ }^{160}$ Besides adding costs, Sacramento's decree states that the Proposition 187 "could put the City at risk of losing certain federal funds" for noncompliance, and raise liability issues "related to defamation and privacy." City staff would be also required to give advice on immigration law, which is "outside their area of expertise," the resolution states.

Sacramento’s self-proclaimed activist mayor, Joe Serna Jr., promoted the council's agenda at a downtown rally against Proposition 187. On October 26, Serna and two city council members--Deborah Ortiz and Darrell Steinberg--urged a "no" vote on the measure (Hayward, 1994b). "What this proposition does is fundamentally divide Californians along race lines," the former city councilman told a Sacramento Bee reporter. As mayor of this city, would I be stopped and asked to prove my citizenship?" (Hayward, 1994a, p. A1). Officials promised a multiethnic crowd of about 250 that they would protect the interests of undocumented residents.

Two days later, the same group, plus council member Sam Pannell and council candidate Steve Cohn, appeared before a crowd of more than 800 grassroots activists (Davila, 1994). The meeting was organized to address concerns of delegates from the Sacramento Valley Organizing Committee (SVOC). ${ }^{161}$ The crowd cheered wildly as each

\footnotetext{
${ }^{160}$ Resolution No. 94-561 (September 13, 1994).

161 The SVOC is made up of congregations from Protestant and Catholic churches in the Sacramento area. The coalition, a local arm of the nationwide Industrial Areas Foundation, is concerned with issues facing low-income communities.
} 
elected official announced opposition to Proposition 187. Even so, a majority of Sacramentans voted in favor of Proposition 187 (“California's Proposition 187,” 2012).

In January 1995, Mayor Joe Serna Jr. accepted an invitation from President Clinton to give the White House advice on federal welfare reform. He was one of two mayors invited to Clinton's workshop, which included a bipartisan group of governors, members of Congress, county and state representatives from across the country (Bee, 1995). John Molloy, Sacramento Housing and Redevelopment Agency director went with Serena (Hicks, 1995).

Before leaving for Washington, D.C., Serna shared with reporters the message he planned to deliver to the nation's leaders. "The best welfare check is a paycheck," he said. "If you're gonna talk about reform, which I support, it has to be coupled with a serious discussion about jobs" (Hicks, 1995, p. B1). Serna pledged to "test the Republican mettle" on their commitment to restructuring welfare to provide opportunities for the poor. “They're for jobs, I'm for jobs. Put your money where your mouth is. Republicans want to take people off welfare - fine. Train them and find them jobs in the private sector" (Hicks 1995, p. B1). The new mayor also mentioned his ideas for local welfare reform. The city of Sacramento, he disclosed, had begun discussions with county officials about a pilot program that would place social programs, such as Aid to Families with Dependent Children, under city control. "Most of the social services-dependent population in the county lives in the city," Serna said. "So though we may not run those programs directly, they have a big impact on the city" (Hicks, 1995, p. B1). 
Despite opposition from municipal leaders, in 1996 President Clinton signed the Personal Responsibility and Work Opportunity Reconciliation Act (PRWOR) into law. ${ }^{162}$ To provide a safety net for those no longer eligible for assistance (which included unauthorized and poor legal immigrants), Mayor Joe Serna Jr. called for shared response to the local consequences of state and federal welfare reforms (Eifertsen, 1997). Even though the county is responsible for welfare programs, he said, the city has a vested interest in how the county implements welfare reform. "Forty thousand families will be affected by welfare reform," Serna said during a town hall meeting. "Sixty percent of those 40,000 live within the city limits" (Eifertsen, 1997, p. N1).

Building on a partnership developed during a January 1996 Welfare Summit, the city and county of Sacramento collaborated to implement its own version of welfare reform. That conference, held at the Sacramento Convention Center, included the heads of the boards of supervisors from the state's nine most populous counties, and big-city mayors from those counties, including Sacramento, which convened the meeting (Griffith,1996b) . "It's only through this conglomeration of cities and counties that we can bring enough political clout to get anyone's attention," explained Sacramento Supervisor Dave Cox (Griffith, 1996a, p. B1). ${ }^{163}$

The group drafted a resolution calling for a say in the welfare reform debate, greater flexibility in operating the General Assistant program, and more cash to pay for the services needed to catch those who would be thrown off the welfare rolls (Griffith,

\footnotetext{
${ }_{162}^{162}$ PRWORA, Pub. L. 104-193, 110 Stat. 2105.

${ }^{163}$ Counties on the invitation list are: Los Angeles, San Diego, Orange, Santa Clara, San Bernardino, Alameda, Riverside, San Francisco and Fresno. Cities include: Los Angeles, Long Beach, San Diego, Anaheim, Santa Ana, San Jose, San Bernardino, Oakland, Riverside, San Francisco and Fresno (Griffith, 1996b).
} 
1996b). The resolution was approved by the local jurisdictions and then forwarded to state and federal legislators. The following month, the city-county coalition met to launch its lobbying strategy. The aim was to increase public awareness of the pending funding crisis (Griffith, 1996b). ${ }^{164}$ “"There will be more indigent people on city streets which will present problems to our fire and medical units as well as the Police Department and the merchants," City Manager Bill Edgar said in a press interview. "We are very concerned about that" (Griffith, 1996a, p. B1).

After PRWOR, the city and county formed an interagency Welfare Reform Partnership to ensure residents had uninterrupted access to social and municipal services. The Sacramento City Council adopted two resolutions in 1997--one approving its formation, and the other pledging support for the new partnership. ${ }^{165}$ The City's role in the welfare reform partnership was to provide "an array of support services to deal with public policy issues and the mobilization of communities and their neighborhood-based businesses" (County of Sacramento, 1997).

Still, many service employees in Sacramento and their families remained at or below the poverty line. ${ }^{166}$ In response to this issue, in September 2003 the Sacramento City Council voted 6-2 to adopt a living wage ordinance (Bacher, 2003a). ${ }^{167}$ A coalition of labor organizers and living wage advocates proposed the ordinance and campaigned

\footnotetext{
${ }^{164}$ Local leaders predicted that welfare reform efforts would cost an additional $\$ 40$ million in General Assistance in 1996.

${ }^{165}$ Resolution No. 97-391 (adopted July 1997) approves a set of principles, created by the Welfare to Work Policy Board (which includes representatives from the Sacramento City Council) to guide the collaborative effort. Resolution No. 97-573 (adopted October 7, 1997) pledges to support the nine strategies for comprehensive interagency welfare reform and directs city staff to participate in interagency efforts to implement the strategies.

${ }^{166}$ In 2001 , about $30 \%$ of the city's residents made less than the regions median income of $\$ 52,000$ for a family of four (Martineau, 2001).

${ }^{167}$ Ordinance No. 2003-082 (enacted December 9, 2003).
} 
four years before achieving victory (Martineau, 2001). Since Sacramento is a principal provider of social support services, and also contracts with employers who do not adequately compensate workers or pay for health benefits, the council decided to consider it.

Sacramento's Living Wage Ordinance (LWO) broadly applies to businesses that contract with the city, and companies that receive financial assistance from or through the City (including grants, loans, tax abatements or tax increment financing). It also applies to firms that lease property owned or controlled by the City. Nonprofit firms are exempt under certain conditions. Direct employees of the City of Sacramento are covered, and workers who are performing city-related work for businesses that receive city service contracts, financial assistant or city leases. This applies whether the individual works fulltime or part-time, is a contingent or contract employee. ${ }^{168}$ The required wage is $\$ 10.00$ per hour with health benefits, or $\$ 12.84$ if health benefits are not provided. ${ }^{169}$ The ordinance also includes a section about other labor standards such as paid day off requirements, anti-retaliation rights and worker retention. Councilors also adopted a resolution authorizing the City Manager to fund a full-time staff position in order to ensure the successful implementation of the LWO. ${ }^{170}$

\footnotetext{
168 "Covered Employee" does not include temporary or seasonal city employees, student interns or individuals participating in specialized training programs.

${ }^{169}$ The wages indexed annually to reflect change in the Consumer Price Index.

${ }^{170}$ Resolution No. 2003-874 (December 9, 2003).
} 
While the LWO only covers a relative small fraction of workers within the city, it covers a much higher proportion of immigrants. ${ }^{171}$ Immigrants working for city contractors of services like facility and building maintenance, janitorial, laundry, pest control, tree trimming, and security. Nevertheless, the LWO was not pitched as an immigrant measure.

\section{"Locally legal” identification cards}

Uneasiness generated by September 11 added to the crush of Mexican citizens flooding the Sacramento consulate for national identity cards, Consul Luis Enrique Castresana explained in a press interview (Korber, 2001). In 2001, demand for the ID cards more than doubled over last year. "This November, we gave out 5,600 identification cards," he told the Sacramento Bee. "Last year, the same month, we passed out just 2,000 cards. It's a significant increase" (Korber, 2001, p. B1). The consulates aggressive, month long campaign to inform Sacramentans about the money-saving benefits of the Mexican ID card also heightened demand. In September, the consulate distributed 40,000 information fliers at community meetings, in newspapers and at matrícula application sites (Bazar, 2002). The flyers provided step-by-step instructions on how to use the government-issued photo ID to open a bank account with ATM access, to bypass expensive wire-transfer services.

The Sacramento Valley Organizing Community (SVOC), a coalition of more than 40 Sacramento area churches, also helped sign up Mexican citizens for the matrícula consular card. In 2002, the group convened a series of rallies at local churches to get the

\footnotetext{
${ }^{171}$ Project manager Mike Medema estimated that the ordinance would affect "less than a thousand" low wage employees (Furillo, 2002).
} 
word out about the post-9/11 need for official ID (Davila, 2002). At the rallies, organizers read letters written by Sacramento County sheriff's officials, and Sacramento Police Chief Arturo Venegas Jr., agreeing to recognize the card (Davila, 2002). Staff from Bank of America and Wells Fargo Bank was on hand to open accounts for new cardholders, while lawyers answered questions about immigration issues. After the meetings hundreds of participants signed up to get Mexican ID cards (Davila, 2002).

While a police agency decision to recognize the card provokes protests in other cities, it was not a big deal in Sacramento (even though the card is not recognized by the state of California). ${ }^{172}$ The European American Culture Council of Sacramento-a group that encourages people of European descent to learn more about their heritagethreatened to protest at the Capital, but never did (Bazar, 2003d). Barbara Coe, chairwomen of California Coalition for Immigration Reform (CCIR) and co-author of Proposition 187, called the ID card "an outright free pass for terrorists" (Bazar, 2003d, p. A1). When queried about this charge, Sgt. Justin Risley said officials at the Sacramento Police Department were not overly concerned about the card's security. "The fact of the matter is, as far as being fraudulent, there's probably more fraudulent California driver's licenses and Social Security cards than we've seen in this arena" (Bazar, 2003d, p. A1). That was the end of that.

\footnotetext{
${ }^{172}$ In April 2003, the California Assembly approved legislation (AB 522) that would require city and county officers and employees to accept identification cards issued by the Mexican Consulate for personal identification. The measure was vetoed in the Senate (Sanders, 2003).
} 


\section{Worksite deportation raids}

Almost nothing is published in the local press about worksite immigration raids, and city leaders took just one fleeting stand on the issue. ${ }^{173}$ In 1990 , the Sacramento City Council adopted a resolution urging "the President and the Attorney General of the United States to direct the Commissioner of the Immigration and Naturalization Service to implement a moratorium on any searches, raids or sweeps for undocumented workers commencing immediately and ending on July $31,1990 . "{ }^{~} 174$ City staff recommended the resolution.

The First Vice President of La Raza National Lawyers Association, Larry Duran, spoke in support of the moratorium. He also requested council action on the issue. A community resident, Brian Weller, spoke against the raid halt. He argued that "unnaturalized citizens should not be counted as part of the United States Census" (Burrowes, 1990, p. 11). That was the extent of public testimony.

Undercounting of the Hispanic population in the 1980 census, and concerns about a repeat in the 1990 census, prompted the City Council to act. Since INS raids create fear among the Hispanic community, a moratorium was needed to encourage maximum participation in the 1990 census, city leaders reasoned. Adequate state and federal funding, district reapportionment, and budget forecasting depends on good census data. According to the U.S. Census, persons of Hispanic origin comprised 14.2 percent of Sacramento's population in 1980, and 16.2 percent in 1990.

\footnotetext{
${ }^{173}$ There may be less ICE raid activity in Sacramento because there are far fewer unauthorized immigrants in Sacramento than in other parts of California (Hill \& Johnson, 2011).

${ }^{174}$ Resolution No. 90-171 (adopted March 6, 1990).
} 


\section{Unregulated day labor-contractor market exchanges}

Unregulated day labor-contractor market exchanges have not provoked much controversy in Sacramento. Crowds of mostly Latino day laborers started gathering in the AMPM parking lot to look for work in 2002. The convenience store, on the corner of $47^{\text {th }}$ Avenue and Martin Luther King Jr. Boulevard, is in unincorporated south Sacramento County (Milbourn, 2007). According to those familiar with the local immigrant labor picture, there is no large day labor site in the Sacramento region besides this one ("Daylaborers Skirt Law,” 2006).

Numbers vary by day and season, but on summer weekends, the count swells to 400 or more ("Day-laborers Skirt Law," 2006). According to the Sacramento Business Journal, police respond to complaints from business owners by shooing people away, knowing that day laborers will turn the corner and come right back. Unless there is an arrest for an illegal act nobody checks for immigration paperwork, a sheriff department representative told a local journalist. "Immigration is a federal issue," he said ("Daylaborers Skirt Law,” 2006, para. 22).

The County sheriff's department and County supervisor agree that law enforcement time and money is better spent on serious crime prevention, rather than on loitering calls. Immigration enforcement is not a local duty but health and safety is, they told a Sacramento Business Journal reporter. So a coalition of representatives from city and county government, law enforcement, business groups and the Mexican consulate, worked together to establish a community center that would include a day labor hiring center. "We are looking for a long-term, sustainable solution," said Sacramento County 
sheriff's Capt. R.C. Smith. "We want to take a multidisciplinary approach, not a simple law-and-justice one" ("Day-laborers Skirt Law," 2006, para. 30). The group has located property in the nearby neighborhood and found a nonprofit to run the project-Community Resource Project Inc. (Community Resource Project Inc., n.d.). ${ }^{175}$

CRP bought a burned house a few blocks from where the workers congregate informally, and is in the process of rehabbing it. The $41^{\text {st }}$ Avenue Community Center, as it is called, will be a hub that connects local residents with multiple community-based organizations that offer employment and training programs, youth services, small business and microenterprise courses, health and dental services, and a day labor center (Community Resource Project Inc., n.d.). No public funds were used. CPR obtained funding from Citibank, Kaiser and other private sources (Ferriss, 2007; "Proposed DayLabor Center,” 2007).

There does not appear to be any opposition to the proposed center, according to Sacramento Business Journal staff, who has been tracking the CPR operation. Except one man who sits across the street from the AMPM convenience store, "videotapes the crowd and yells obscenities at them, claiming immigrant labor cost him his job" ("Proposed Day-Labor Center,” 2007, para. 34).

${ }^{175} \mathrm{CPR}$ was founded in 1972 to serve ex-felons, and offers a variety of services to low-income families in the Greater Sacramento area. 


\section{City Profile}

Denver, the capital and most populous city in Colorado, is a consolidated citycounty. ${ }^{177}$ It is located in the Intermountain West region of the United States. After losing population in the 1980s, Denver has grown rapidly thanks to its reemergence as a gateway for immigrants and "cool" destination for young adults. According to the Brookings Institution Center on Urban and Metropolitan Policy (2003), the population grew by nearly 19 percent in the 1990s, and 8 percent the next decade. Most of this growth is attributable to foreign in-migration. Denver's foreign-born population just about tripled during the 1990s. Nearly two-thirds of those newcomers came from Mexico, with smaller numbers arriving from South East Asia and European countries. Notably, “62 percent of Denver's foreign-born residents arrived between 1990 and 2000" (p.5). ${ }^{178}$

Still, Denver is an "Established Latino Metro"- an urban area with a large, longstanding Hispanic population base (Suro \& Singer, 2002). During the 1960s and 1970s, the city was one the epicenters of the Chicano movement (Esquivel, 2008). Today, nearly one-third of Denver's residents are Hispanic (with Mexican Americans comprising 31.2 percent). NonHispanic whites, the Census Bureau estimates, make up just about half (52.3 percent) of the city's population. No other group is present in a proportion greater than 10 percent. ${ }^{179}$ The presence of single dominant minority group contributes to a

\footnotetext{
${ }^{176}$ U.S. Census Bureau, Census 2010.

${ }^{177}$ In operation, Denver is primarily a municipality, but some of its officers are also county official and have jurisdiction and functions broader in scope than their counterparts in other cities.

${ }^{178}$ Denver's foreign-born population went from 142,434 to 369,903 between 1990 and 2000.

${ }^{179}$ Black or African American 10.2\%, Asian and Pacific Islander 3.5\%, and American Indians and Alaska Natives 1.4\% (U.S. Census Bureau, Census 2010).
} 
distinctive Denver attribute: "its centrality in legislative and public opinion debates concerning immigration” (Denver Office of Community Support, n.d., para. 4).

Another factor that makes the city unique is its top ranking as a magnet for twenty- and thirtysomethings. Since the mid-2000s, Denver has been a leading gainer of young movers age 25-35(Frey, 2011). ${ }^{180}$ They helped made Denver one of the most educated cities in the United States; slightly more than 40 percent of its residents age 25 and older hold at least a bachelor's degree (Frey, 2011). Denver's robust labor market has made this "mountain mega" a good place for young people and immigrants to jump start their lives (Frey \& Muro, 2008).

Spurred by this growth, Denver's economy has transitioned sharply away from heavy dependence on resources-based industry toward "New West" business ventures, linked to information and communications technology along with aerospace manufacturing and tourism. The city is also home to the Western branch of many federal agencies, and remains an important agribusiness and transportation hub.

Telecommunications and biomedical technology are two of the largest industries. Construction, real estate, and retail trade are among the fastest growing industries (Murray, 2002).

The median value of housing $(\$ 165,800)$ in Denver is above the national average, and rents increased rapidly during the $1990 \mathrm{~s} .{ }^{181}$ Labor shortages in the construction industry drove up the cost of building, which was passed onto tenants and homeowners. An aging labor force, and the fact that high school seniors are not interested in doing

\footnotetext{
${ }^{180}$ Denver moved from twelfth (2005-2007) to first (2008-2010) in rank as a destination for young adults (Frey, 2011).

${ }^{181}$ U.S. Census Bureau, Census 2000.
} 
back-breaking masonry when they can sit behind a computer for the same money, account for the dwindling construction labor pool (Johansen, 2000). Denver's technofueled economic boom further drained the city's low-tech labor pool. Restaurants, hotels, nursing homes and construction contractors looked to Mexico for a solution (Austin, 2000).

The city's political leaders enthusiastically embrace Denver's shifting image from frontier cow town to international city. This spirit is captured on the it's GlobalDenver.org website, which highlights features that will, as Futurist McKinely Conway predicted, make Denver a "supercity"; Denver ranks number 5 on his list of cities posed to attain super status (Conway, 1999). ${ }^{182}$ The website showcases Denver's world-class airport, and positions the city as "a hub in the new global economy." It points out that Denver is home to 83 foreign-based companies with over 17,000 employees, and 743 local companies also participate in the global economy through exports. The city also attracts over 180,000 foreign tourists and 5,000 foreign students to the region every year. Another web page profiles the city's various ethnic communities and connections to the rest of the world. It emphasizes the number of foreign-born residing in the city $(17 \%)$, lists Denver's sister cities, and local cultural activities. Denver's big-league sports franchises and convention engagements are also mentioned. Denver hosted the 2008 Democratic National Convention and the 2000 National Convention of the Green Party.

\footnotetext{
${ }^{182}$ A supercity is an urban area with three characteristics: it has a population over a million; a sustainable capacity for meeting the physical and social needs of its residents; a healthy and dynamic economic environment that produces, attracts, and nurtures economic investments that produce adequate jobs and public revenues (Conway, 1999).
} 
It was the site of the G7 (now G8) summit in 1997 and hemispheric meeting of trade ministries in 1995. The NCCAA Final Four in 1990, and visit of Pope John Paul II in 1993, helped put Denver on the world stage (Finley, 1995).

The city's diverse leadership is another international asset. In the last twenty-nine years Denver has elected only one Anglo mayor, John Hickenlooper (2003-2011). Voters chose Federico Peña as the city's first Hispanic mayor in 1983. Eight years later, they elected Wellington Webb as their first black mayor (1991-2003). Webb won a contest in which both candidates were African-American, and 68 percent of the left-leaning voters were nonHispanic white (O'Driscoll \& El Nasser, 2004). Guillermo "Bill" Vida took the reins as Denver mayor when Hickenlooper left to become Colorado's governor. Vida was Denver's first (Cuban) immigrant mayor. He served as deputy mayor under Hickenlooper for six years. Denver's second African American mayor, Michael Hancock, is the current mayor. John Hickenlooper filled two-thirds of his top posts with blacks, Latinos and Asians while in office (O’Driscoll \& El Nasser, 2004).

While Denver elections are non-partisan, Democrats have long held a majority sway on city politics with most elected officials having Democratic Party affiliation. The office of Denver's Mayor has been occupied by a Democrat since the municipal general election of 1963. In a nationwide study of the most conservative and liberal U.S. cities, Denver ranked 47 (out of 237 cities) on the liberal list (BACVR, n.d.). Denver has a strong mayor/weak city council government, and is home to a strong grassroots antiillegal immigrant movement. Denver is also included among the top ten cities for Latinos in the U.S. by Hispanic Magazine, on the basis of population share, political and cultural 
influence, and quality of life. The magazine describes Denver's Hispanic political and business community as strong and well-organized (Aguilar, 2001).

\section{Unauthorized Immigration Policy}

The biggest story in Denver has been the long, fierce campaign to rescind three policies that opponents cite as proof that Denver is a "sanctuary city" for "illegal" immigrants. Each of these policies extends the rights and benefits of citizenship to unauthorized immigrants, through de facto political membership and access to publicly funded services--police and social programs. Day laborer-contractor market exchanges have also generated disputes. Immigration raids and the issue of amnesty for locals are of lesser significance. Asylum for Central American refugees was not on Denver's political agenda.

\section{Government benefits for noncitizen}

Executive Order No. 116 was issued in 1998 by Mayor Wellington E. Webb. U.S. Rep. Tom Tancredo (R-Colorado), ${ }^{183}$ and other Colorado anti-illegal-immigrant activists have doggedly criticized the city's policies on foreigners ever since. Opponents claim E.O. 116, and policies like it, allow "illegal aliens" to live in the city without fear of deportation. Denver officials deny it. In a 1999 letter to the Denver police chief, former City Attorney Daniel E. Muse argues this:

Executive Order No. 116 expresses a clear intent and policy to preserve the rights of residents of the City and County of Denver irrespective of their citizenship. Executive Order No. 116 discourages reporting undocumented aliens who seek essential services (Muse, 1999, p. 3).

\footnotetext{
${ }^{183}$ Tancredo is a former Republican member of the U.S. House of Representatives from Colorado's $6^{\text {th }}$ congressional district; a district that includes most of Denver's southern suburbs. He founded the House Immigration Reform Caucus and was a declared candidate for the 2008 Republican presidential nomination running on an anti-illegal immigration platform.
} 
The "limited cooperation ordinance" as Muse calls it, does not explicitly state this. The policy describes Denver as an ethnically and culturally pluralistic emerging international city. It expresses opposition to 1996 PRWOR Act (with its unfair distinctions between qualified and unqualified legal immigrants), spells out the city's anti-discrimination stance and commitment to deliver services to all of its residents. James Mejia, former executive of Denver's Agency of Human Rights and Community Relations drafted the order. It was a response to the local impact of the federal legislation.

Webb introduced his new directive during a press conference at a Mexican restaurant. He said unfair federal welfare reforms, and citizenship backlogs, compelled him to act. This quote lays out the mayor's position:

Denver will not allow the divisive policies and bureaucratic delays on the national level to undermine our firm commitment to the delivery of services to all of our residents. This is a pledge that I have made from the day I assumed office, and it is a commitment that remains a fundamental principle of my administration. We are an international City, enriched and energized by our immigrant population. And while we are disappointed by the inequities of the federal legislation, we do not accept its consequences passively (Webb, 1998, p. 5).

When issued, Executive Order No. 116 was estimated to cost Denver taxpayers about \$1 million annually (Finley, 1998). ${ }^{184}$ Webb's director of policy, Shepard Nevel, said we are "providing food vouchers with state dollars to legal immigrants who are no longer eligible for food stamps and are also providing job training, some medical care and housing assistance" (Finley, 1998, p. B1).

Before introducing Executive Order No. 116, Webb traveled to Washington, D.C. to urge lawmakers to soften the recently enacted welfare reform bill (Callaway \& Bierbauer, 1996). An act he, and other members of the U.S. Conference of Mayors,

${ }^{184}$ Kitty Pring, senior Denver Department of Social Services official (Finley, 1998). 
feared would exacerbate existing hunger and homelessness problems in cities (Harrington, 1994). Webb also used his position in the U.S. Conference of Mayors to encourage public and private institutions in Denver, and other cities, to adopt measures similar to Denver's social policy for foreign residents-E.O. 116 (Finley, 1998).

Mayor Webb also spoke out against California's Proposition 187—a law he called "mean-spirited" and "flying in the face of NAFTA" (Harrington, 1994, p. B1; "Two Wrong-headed Boycotts," 1994, B7). At a 1994 rally, Webb told the crowd that a similar ballot measure would not gain a toe-hold in Denver (Richardson, 1994). He also promised to support community activists in their fight against the initiative (Covarrubias, 1994). Afterwards, his office was flooded with angry telephone messages and faxes. Some Denverites mistakenly believed Webb had called for a boycott of California (Lopez, 1994). No city-backed sanctions against California were ever taken, and the mayor advised protestors to be geographically selective if they decided to boycott the state. $^{185}$

In the mid-2000s, Colorado's “illegal alien" opponents coalesced to pressure Denver's new mayor, John Hickenlooper, ${ }^{186}$ to overturn the city's social policy on immigrants. ${ }^{187}$ In June of 2006, they erected a 48-foot-by-14-foot billboard near a restaurant owned by Hickenlooper as part of their anti-sanctuary campaign (Kreck, 2006). The sign depicted a symbol for fallen soldiers and said, "Mr. President Mr.

\footnotetext{
${ }^{185}$ Webb's recommendations were based on his own experience with a statewide boycott. In 1992, California boycotted Colorado products after state voters there approved an anti-gay rights measure. Denver suffered even though it had not supported the amendment (Covarrubias, 1994).

${ }^{186}$ Mayor John Hickenlooper, a geologist-turned brewpub pioneer (and downtown activist) was elected in 2003 and re-elected in 2007. In 2005, Time Magazine named the political newcomer one of the top five "big-city" mayors in America (Brown, 2005).

${ }^{187}$ Prior to this time Denver had no organized anti-illegal immigrant movement.
} 
Governor. Mr. Mayor--They did not die for ILLEGAL SANCTUARY!” Another similarsize billboard near I-25 declared: "Welcome to SANCTUARY CITY...Relax, you made it! Brought to you by Executive Order 116" (Jones, 2006; Kim, 2006c; Mitchell, 2006)

A crowd of 100-130 supporters gathered in a parking lot under the sign on California Street for the billboard unveiling ceremony. Denver radio talk-show host Peter Boyles aired his show live from the site. Boyles spearheaded the billboard campaign. KHOW listeners paid $(\$ 18,500)$ for the two billboards, which stayed up for one month (“Two Billboards," 2006). Rep. Tom Tancredo, and Jim Gilchrist, founder of the Minutemen Project (border patrol effort), attended the event (Kim, 2006c; Mitchell, 2006).

Lindy Eichenbaum-Lent, spokeswoman for Mayor John Hickenlooper denied the "sanctuary city" claim made by activists. She said:

There are no ordinances, executive orders or regulations that establish a 'sanctuary policy' in Denver. Denver's policies comply with federal law, and Denver law enforcement officers cooperate with federal officials on immigration matters. Federal Immigration and Customs Enforcement officials have said Denver is not a sanctuary city, so merely erecting a misleading billboard doesn't make it true (Kim, 2006c, para. 6, 7).

Besides igniting the "sanctuary city" controversy, the billboard event provided a venue for volunteers from Defend Colorado Now to gather petition signatures for the group's ballot measure. ${ }^{188}$ If voters approved their proposed constitutional amendment, it would prevent unauthorized immigrants from receiving any state or local services, and would allow citizens to sue any agency or local government suspected of providing services.

\footnotetext{
188 The success by anti-illegal-immigration forces in Arizona with Proposition 200 led to a nationwide strategy to pass similarly worded initiatives across the country. Colorado was chosen as the next target, according to Wade Henderson, of the Leadership Conference on Civil Rights in Washington, because it is known to have a hard-core base of anti-immigration activists (Riley, 2006).
} 
The measure did not make it onto the November ballot. ${ }^{189}$ The Colorado Supreme Court disqualified it (Aguilera, 2005b; Riley, 2006; Jones, 2006; Jansen, 2006). Former mayor and U.S. Cabinet member, Federico Peña, led the Keep Colorado Safe campaign against the ballot initiative. He called the amendment "mean spirited" and warned Colorado voters that it would "hurt innocent children and create a health crisis by denying things like immunizations" (Aguilera, 2006).

The court ruling incensed the group backing the proposal, which included Dick Lamm, the former Democratic governor and current leader of Defend Colorado Now. They pressured their representatives in congress to curtail "bottom up" amnesty for “illegal” immigrants at the local level. In response, Republican Governor Bill Owens called lawmakers into a special session. The Colorado Legislature approved a bipartisan package of restrictive illegal immigration laws (“Colorado Lawmakers," 2006). ${ }^{190}$ The cornerstone measure requires state and local agencies to verify the immigration status of persons 18 years old and older who apply for state, local or federal public benefits. ${ }^{191}$ It also prohibits state agencies or political subdivisions from providing benefits in violation of the act. The bill establishes reporting requirements and specifies criminal penalties for “falsifying a required affidavit." Emergency services are exempt. ${ }^{192}$

\footnotetext{
${ }^{189}$ Their proposed constitutional amendment is identical to one filed in 2005 by Defend Colorado Now leaders and Tom Tancredo, R-Colo (Aguliera, 2005b).

${ }^{190}$ HB 06S-1023 (denies non-emergency state and federal benefits to undocumented immigrants); HB 06S1017 (requires employers to verify the legal status of their employees) (Jansen, 2006).

${ }^{191}$ The bill uses a federal list of services that could be barred.

${ }^{192}$ HB 06S-1023 (signed July 10, 2006; effective on August 1, 2006).
} 
The aim was to "put teeth into existing federal regulations," Owen told Fox News ("Colorado Lawmakers," 2006, para. 9). According to reporters, the group that backed the failed ballot proposal, Defend Colorado Now, was satisfied with the new bill (“Colorado Lawmakers," 2006). ${ }^{193}$

The devolution of immigration law enforcement

In the mid 1980s, Denver police officers would pick up and arrest unauthorized immigrants simply because they were in the country illegally, Denver police sergeant Mike Scanlon said in a Denver Westword press interview. But that stopped in the 1990s. "Now we can't do that," he said. "We're not interested in immigration status and nationalities. We don't have room in the jails for our own crooks, much less them" Bowers, 1995, para. 13). His policy on criminal aliens is different. "I have the guys notify the INS when we pick them up. I don't know what happens then," Scanlon added (Bowers, 1995, para. 15). Sometimes agents respond but often they do not. ${ }^{194}$

The Denver Police Department's policy on foreign nationals_-104.52, was formalized after Mayor Wellington Web enacted Executive Order 116 in 1998. The most controversial, misinterpreted element of the policy deals with the arrest and detention of foreign nationals (Hudson, 2005; Spencer, 2006). The first section of 104.52 says Immigration and Naturalization Service (now ICE) is responsible for enforcing immigration laws. It reads:

\footnotetext{
${ }^{193}$ The citizen initiative would have asked voters to bar state services to illegal immigrants and let the Colorado Legislature define those services, while the bill uses a federal list of services that could be barred. ${ }^{194}$ Bob Firth, one of the two agents assigned in the Denver city jail, confirmed the hit-or-miss situation. Due to heavy workload, the agents were only interviewing and processing illegal aliens arrested on drug charges (Powers, 1995).
} 
Denver Police officers shall not initiate police actions with the primary objective of discovering the immigration status of a person. ${ }^{195}$ Generally, officers will not detain, arrest or take enforcement action against a person solely because he/she is suspected of being an undocumented immigrant. ${ }^{196}$ However, when a suspect believed to be an undocumented immigrant is arrested for other charges, a 'Refer to Immigration' charge will be added to the original charges. Sheriff's Department personnel will then notify the I.N.S authorities according to their procedures. $^{197}$

The policy was fiercely attacked by anti-illegal immigrant groups beginning in 2005 , and opposition continues today.

Before then, another police policy was the center of debate. In 2002, leaders of the All Nations Alliance, a coalition of over 80 community-based social justice organizations, asked Mayor Webb to issue an executive order to stop cops from assisting with the federal government's anti-terrorism campaign (Knight, 2002). The Denver City Council adopted an anti-Patriot Act resolution instead. ${ }^{198}$ Councilwoman Kathleen MacKenzie, who co-sponsored it, said the measure was needed to keep police from trampling civil rights of Denver's non-citizen residents after 9/11 (Cooke, 2002a; Riley, 2002). After a two hour debate, council members approved the mildly-worded decree by a 7-4 vote in front of a standing-room-only audience of advocates (Cooke, 2002a; Riley, 2002).

\footnotetext{
${ }^{195}$ Denver Police Department Operating Manual, 90-100, 104.52 (3a), Rev.1-06.

${ }^{196}$ Denver Police Department Operating Manual, 90-100, 104.52 (3b), Rev. 1-06

${ }^{197}$ Denver Police Department Operating Manual, 90-100, 104.52 (3c), Rev. 1-06

${ }^{198}$ Resolution No. 14, Series of 2002 (March 18, 2002). Colorado passed a similar resolution on May 9 , 2005.
} 
The decree lets federal officials know that the council is committed to fighting terrorism but not at the expense of civil rights and liberties. It also reaffirms the City's already existing (but unimplemented) written policy on unbiased policing ${ }^{199}$ and commitment to protecting people who haven't committed a crime from police investigation. ${ }^{200}$ The Mayor, Manager of Safety, and Chief of Police vowed to ensure that the police policy "will remain in full force and effect.",201 Language about limiting cooperation between Denver police and federal terrorist investigators was removed from the original resolution before the final version passed. ${ }^{202}$

According to the Federal Bureau of Investigation, Denver was one of the first U.S. cities to establish at Joint Terrorism Task Force (JTTF). ${ }^{203}$ A detective from the Denver Police Department's Intelligence Unit has been working full-time for the Denver JTTF since 1997. Since 2003, the Denver Police Department has assigned two full-time detectives to the JTTF (ACLU of Colorado, n.d.; FBI, Denver Division, n.d.). "It makes sense for an international terrorism unit to be based in Denver," a FBI supervisor said in a press interview. Being an international city, it "brings the good and bad from countries all over the world" (Pankratz, 2001, A18). Even so, council members who voted against the

\footnotetext{
${ }^{199}$ Denver Police Department Operating Manual, 90-100, 118.02 (Rev. 01-06).

${ }^{200}$ Denver Police Department Operating Manual, 90-100, 118.03 (Rev. 01-06).

${ }^{201}$ According to a June 30, 2002 judicial review panel report, the captain of the Intelligence Bureau who wrote the policy did not bother to distribute it to other officers (ACLU of Colorado, n.d.).

${ }^{202}$ American Indian activist, Glenn Morris, wrote the original resolution.

${ }^{203}$ Denver is home to FBI Domestic Terrorism "Squad 5," a field intelligence group established to proactively gather information on key security and criminal threats (FBI, Denver Division, n.d.).
} 
resolution claimed it would make Denver a haven for terrorists (Schabner, 2003). Mayor Webb endorsed the resolution at a news conference anyway. Later, he incorporated its language into the Denver Police Department Operating Manual. ${ }^{204}$

The city's civil liberties resolution passed amid controversy over the Denver Police Department practice of keeping secret files on peaceful protest groups. Resolution text about information gathering and dissemination was prompted by the American Civil Liberties Union's class-action against the City for unconstitutional police practices. ${ }^{205}$

Mayor Webb convened a three-judge panel to review the city's police spy files and adopted most of their recommendations. Still, activists were critical of the limited scope of the panel review, which did not include anti-terrorism investigations. According to Steve Nash, a plaintiff in the Denver ACLU lawsuit, Denver had no public JTTF renewal hearings. "I've seen nothing in the press about it. I've heard nothing from the police about any kind of renewal process. Sometimes they do public things that aren't very public," he reported (Hellegers \& Mercier, 2002).

On December 30, 2004, the ACLU legal director in Colorado, Mark Silverstein, wrote Denver's elected officials urging them to reconsider the continued role of police in the FBI JTTF. The letter explained that "JTTF activities may pose a greater threat to civil liberties than the Denver Police Department practices that spawned the Spy Files controversy" (ACLU of Colorado, n.d., para. 12). The ACLU sent another letter to Mayor Webb and each member of the Denver City Council in May 2005. It stated that the

\footnotetext{
${ }^{204}$ Denver Police Manual, Rev.1-06, 118.00.

${ }^{205}$ The March 2002 lawsuit against the City and County of Denver challenged the DPD's practice of spying on nonviolent protestors, maintaining secret files, and disseminating information from the files to third parties.
} 
DPD's participation in the JTTF was preventing the City from fulfilling its responsibilities under the Spy Flies settlement agreement. It suggested that Denver follow the example of Portland, Oregon, which resolved a similar accountability problem by withdrawing its detectives from the FBI task force (ACLU of Colorado, 2005).

The Hickenlooper administration refused to allow its two JTTF detectives to be questioned by an outside auditor studying compliance with the legal settlement. City Attorney Cole Finegan refused to comment (Greene, 2005). The Denver Police Department maintains its partnership with the FBI.

Later in 2005, a dishwasher with a fake Social Security card, employed by restaurant owned by Mayor John Hickenlooper, killed a Denver police detective. Restaurant managers told police the 19-year-old had presented a resident-alien card when he applied for the job (Crummy, 2005a). Gomez, Detective Donald Young's accused killer, was an unauthorized Mexican national.

The incident set off a fierce debate about unauthorized immigrants in Denver. It also reignited Rep. Tom Tancredo's campaign to abolish Denver's "sanctuary policies." He blamed Hickenlooper and the Denver Police Department for the murder, alleging the tragedy occurred, in part, because Denver's "sanctuary city" rules prevent police from cooperating with federal immigration officials and act as a magnet for illegals ("Alleged Cop Killer," 2005; Crummy, 2005a). The accusation fueled a series of heated debates between City Hall and anti-immigration activists over whether Denver provides safe haven or "sanctuary" for undocumented immigrants. 
During a testy exchange on the Peter Boyles talk radio show, Tancredo and Denver City Attorney Cole Finegan sparred over E.O. 116 and police policy 104.52, which Tancredo cites as proof Denver has a sanctuary policy. Finegan accused Rep. Tom Tancredo of exploiting the killing of a Denver police officer to push an anti-immigration agenda. He insists Denver has no so-called sanctuary policy—official or unofficial— that keeps officers from making referrals to immigration authorities (Coffield \& Hudson, 2005). "There's no executive order, no ordinance, no regulation in the city of Denver that establishes a sanctuary policy," Finegan countered (Hudson, 2005). Tancredo continues to insist that such a policy exists.

The following week, members of the Colorado Alliance for Immigration Reform (CAIR), and Defend Colorado Now, held press conference and rally to call attention to Denver's illegal alien "sanctuary policies.” Roughly three dozen people gathered on the steps of the Denver City and County Building (CAIRCO, 2005a; Sanchez, 2005). Protestors waved American flags and an image of the mayor urinating on a police badge. They held signs saying "sanctuary kills" (Sanchez, 2005). After the rally, activists handdelivered a letter from CAIR directors to the mayor's chief of staff Michael Bennet. It asked Hickenlooper to issue an order that "unequivocally condemns illegal immigration" in the city (Sanchez, 2005, B4). The letter accuses officials of "putting the 'rights' of criminals over the rights, safety and welfare of citizens." It states Denver's sanctuary policies and practices amount to "shameful, localized de facto amnesty for illegal aliens" (CAIRCO, 2005a). Anti-sanctuary watchdogs demanded that the mayor rescind Executive Order 116, which they described as an "artfully worded treatise on sanctuary 
for illegal immigrants." They also wanted the mayor to change Denver's police policy on the arrest and detention of foreign nationals (CAIRCO, 2005a; Rodríguez, 2005a;

Sanchez, 2005).

In response, Bennet said Denver's order only focuses on legal immigration and says nothing about sanctuary for illegal aliens. "There are some who believe that a traffic stop should become a moment of defining whether someone is in the country illegally or not," Bennet said in a post rally press interview (Sanchez, 2005, B4). "The Police Department's main job is catching people who are committing crimes." He added the city has cooperated fully with immigration officials (Sanchez, 2005, B4).

It is a matter of jurisdiction and manpower, local officers explained when asked why Garcia-Gomez had not been detained or federal agents summoned after he was involved in three traffic accidents. The only time we contact ICE is when we arrest a suspected illegal immigrant for some jailable offense, Sheriff Dan Corsentino explained to the press (Roper, 2005). Denver Police Chief Jim Billings said much the same thing:

If a police officer stops a car with suspected illegals in it, we would issue a ticket to the driver for whatever violation had occurred, but if the occupants of the car had not done anything wrong, we'd let them go. Just being a suspected illegal alien is would not cause someone to be arrested or 'detained' in Denver (Roper, 2005 , para. 8, 9).

Garcia-Gomez reportedly had a valid driver's license from Mexico. Local law enforcement officers are not authorized to do the job of federal immigration agents, Mayor Hicklooper added (Roper, 2005). 
The Homeland Security bill recently approved by Congress provided $\$ 40$ million for training state and local law enforcement agencies how to initiate deportation proceedings, but the Denver Police Department opted out of the 287(g) program (Osher, 2010f).

Another anti-sanctuary rally was held in Denver a few days later, but only about 40 people attended (O'Reilly, 2005). The low turn-out was the topic of the May 15, 2005 O'Reilly Factor Show. O'Reilly interviewed Denver radio talk show host, Peter Boyles, who called the turn out "underwhelming." He said there was not enough pressure on Hickenlooper or the city council to change the sanctuary law (O'Reilly, 2005).

Congressman Tancredo increased the pressure on Denver officials. He wrote the Department of Homeland Security in Washington asking Secretary Michael Chertoff to enforce a ban on what he calls sanctuary states and cities. Others joined the attack on Mayor Hickenlooper. Rep. David Schultheis (R-Colorado Springs) accused the mayor of helping illegal immigrants steal jobs from Colorado residents and driving down salaries for low-income workers (Crummy, 2005a). Former Colorado Governor Dick Lamm, a Democrat and an outspoken opponent of illegal immigration, criticized Hickenlooper for his lax immigration policies. Too many public officials "wink" at the issue, he said during a radio interview. "It's often said our immigration system is broken, but now our lawenforcement system seems to be broken, too," said Mr. Lamm (Crummy, 2005a, A1). In his interview with the governor, radio talk show host Mike Rosen graded Denver. He said that, on a scale of one to 10, with San Francisco being a 10 as sanctuary cities go, Denver was "about a seven" (Crummy, 2005a, A1). 
"What do they want me to do? Should I build a wall around the city?" the mayor said in response to Lamm's accusations that he was skirting the illegal immigration matter (Crummy, 2005a, A1). Hickenlooper told reporters he had refrained from taking on his critics because it is not a local issue. "Local government's role is not to arrest, confine or expel those without valid visas," he said in a press interview. "Our policy is to follow the interpretation of federal law" (Crummy 2005a, A1). Mr. Hickenlooper further explained that it would not be practical for police to take down names of suspected unauthorized immigrants during traffic stops and forward them to U.S. Immigration and Customs Enforcement officials. Not only would such a practice cause people to fear the police, it would encourage racial profiling, he said (Crummy 2005a). Besides, the mayor told the Denver Post, the immigration agency "has already made it clear that they do not have the resources or manpower to pursue minor traffic offenses" (Crummy, 2005a, A1). Denver Police Chief Gerry Whitman agreed. He also questioned whether federal officials would show up if police called them, and expressed concern about fear preventing residents from reporting crimes or testifying as witnesses (Crummy, 2005a).

To further defend the city's policies on foreigners, Hickenlooper cited a 1999 opinion from the city attorney's office. Federal law, according to the legal brief, states that solely being in the United States illegally is a civil violation enforceable only by federal immigration officials. Local police may detain someone only if there is probable cause to believe the person entered the country illegally (Crummy, 2005a). The Mayor and Chief both argued that Denver's police policy complies with federal laws and is 
similar to those used by local law-enforcement agencies in other cities. "It is unfortunate that information being spread is untrue," Mr. Hickenlooper said in a Washington Times interview (Richardson, 2005a, p. A14 ).

On May 17, Congressman Tancredo issued a press release to deliver "a few unpleasant facts" about the "sanctuary policy" that Denver officials say does not exist:

Denver jail officials do not routinely identify illegal aliens in custody and share this information with the Bureau of Immigration and Customs Enforcement. Immigration agents must do this identification themselves with few exceptions. (Tancredo, 2005a, para. 5).

ICE is only called when a major crime is committed and a criminal investigation is already underway (Tancredo, 2005a). That is what happened in the case of the suspect sought by police for the murder of Denver Police Detective Donald Young, Tancredo wrote. "When a city stops calling the immigration enforcement agency to pick up illegal aliens, that agency stops staffing to handle those calls" (Tancredo, 2005a, para. 11). If Denver started making those calls, ICE might respond. "But why should a federal agency worry if Denver doesn't care enough to get these common criminals off their streets?" concluded the congressman (Tancredo, 2005a, para. 11).

The Rocky Mountain News investigated. A few days later the paper issued a report that poked holes in City Hall's story. In a radio interview on KOA-AM (850), Mayor John Hickenlooper said he was "embarrassed" by the News account indicating jail administration practices were at odds with city policy. The report revealed that the Denver Sheriff's Department did not routinely notify federal agents about unauthorized inmates. Talk show host Mike Rosen said he thought jailing an illegal immigrant would 
generate a computer record that alerts ICE about his whereabouts. "My understanding was your understanding," replied the mayor (Kilzer, 2005b, para. 10).

The mayor's chief of staff, Michael Bennet, told the News, "We think it is important that we be clear about what our policies are and that they are followed...If there are inconsistencies, we want to know the cause of it" (Kilzer, 2005a, para. 8). Bennet added that he was not sure if the apparent discrepancies were substantial, or matters of semantics (Kilzer, 2005a). The next day, Hickenlooper met with director of corrections, Fred Oliva, about the apparent inconsistency in procedures. Later, Oliva showed the mayor's office the sheriff department policy on illegal immigrants, which differed from Denver police policy (Kilzer, 2005b). Federal agents announced that they would start routinely asking the Denver Sheriff Department for a list of foreign nations in city jails (Kilzer, 2005b).

Six months later, a local television story gives Tancredo another chance to criticize Denver's police policy. The undercover report alleged that Denver was a gateway for human smuggling from Mexico, and that Denver police allow the trafficking to operate without interference (Scott, Maass \& Hartfield, 2005). In a November 2005 letter, Tancredo calls on Hickenlopper to initiate an investigation of his police department's policies. The Colorado Congressman claims he has received reports from Denver police officers who say their superiors have reprimanded them for trying to call the Immigration and Customs Enforcement (ICE) office in Denver to report illegal aliens, even those involved in human trafficking (Tancredo, 2005b). This police indifference, Tancredo contends, is a direct result of Denver's notorious "sanctuary city" policies, and 
especially the written police department directive that forbids police officers from asking questions about a person's immigration status. "These smugglers know that Denver is hospitable to illegal aliens, so they believe they can operate here without fear of arrest or prosecution," Tancredo writes (Tancredo, 2005b, para. 4). The letter urges Hickenlooper to ask ICE to expand its enforcement capabilities in Denver. Mayor Hickenlooper does not respond.

In December, twenty-nine Colorado Minutemen and CAIR members surprised Hickenlooper at a breakfast fundraiser at El Centro Humanitario Para los Trabajadores, a day labor center. They encircled him, hammering him with questions about Denver's "illegal" alien sanctuary policies. One man poked the Mayor in the chest (Rodríguez, 2005d). This incident was the Mayor's third encounter with the group. They ambushed him at a public meeting earlier in the year, and again after his State on the City address in July (Rodríguez, 2005d). Protestors wanted Hickenlooper to change Denver's Police Manual to require full cooperation with ICE (CAIRCO, 2005-2006). The Mayor's response: "Denver police are underfunded and need to focus on their job, not the job of federal immigration officers" (Rodríguez, 2005d, p. F1). The Minutemen videotaped the event and afterwards, posted it on their website (CAIRCO, 2005-2006; Rodríguez, 2005d). Hickenlooper does not alter police policy.

At a tele-town hall meeting the following month (January 2006), Republican gubernatorial candidate Marc Holtzman added his two-cents to the "sanctuary city" policy debate. He calls the Democratic Denver mayor a "show horse" who runs a "rogue city government" (Crummy, 2006b, B2). Holtzman claims Hickenlooper's policies are 
part of a liberal, "overly secularist agenda" that has permitted illegal immigrants to find sanctuary in Denver (Crummy 2006b, p. B2). He was referring to the case of Raul Gomez-Garcia who allegedly killed Denver Detective Donald Young and wounded Detective John Bishop. “As governor,” Holtzman said, "I will make sure state laws supersede the laws in that rogue city" (Crummy, 2006b, p. B1).

In September 2008, an unauthorized Guatemalan immigrant, charged with causing a crash that left a toddler and two adults dead, pushed Denver's police policy back to the fore in an election-battleground state. Rep. Tom Tancredo was quoted in the Washington Times saying the "blood from this incident" is on the hands of Denver officials for protecting the suspect's identity (Richardson, 2008, p. A1). The suspect, Francis Hernandez, escaped deportation despite numerous arrests in Denver. That is not supposed to happen. A 2006 Colorado law (SB90) requires state and local police to notify federal immigration authorities after arresting suspected illegal aliens for crimes more serious than traffic citations. Cities that do not comply are denied grants by the Department of Local Affairs (Aguilera, 2006). ${ }^{206}$ Before S.B. 90 passed police departments only reported unauthorized immigrants arrested on felony charges.

In a follow up press release, Tancredo wrote: "How many more innocent people must die before Denver gets serious about obeying the law?" (Tancredo, 2008, para. 5). Hernandez has been arrested at least twenty times in the Denver metro area, five of which came after the sanctuary city bill passed in 2006, the Congressman adds (Tancredo, 2008). According to press reports, Tancredo argues, Hernandez was never referred to

\footnotetext{
${ }^{206}$ Municipalities are required to report the General Assembly how they have implemented the law annually.
} 
them federal immigration authorities (Tancredo, 2008). ICE spokesman Carl Rusnok confirmed that the agency had no record of being contacted about Mr. Hernandez (Richardson, 2008).

Mr. Hickenlooper countered Tancredo allegations that Denver offers safe harbor to "illegal" immigrants. He pointed out that Denver routinely refers more than 2,000 arrestees to federal immigration officials annually (Spencer, 2006; Osher, 2010f). ${ }^{207}$ "No matter how many times Congressman Tancredo says it, Denver is not a sanctuary city," the mayor told the Denver Post (Osher, 2010f, para. 5).

Hickenlooper, in fact, welcomed the state law banning "sanctuary" policies for undocumented immigrants. A month before S.B. 90 became law he said this in a press interview:

I think if we pass this bill, that finally people will believe that there is no such thing as a sanctuary city in Colorado. Nativists always mention Denver when complaining about places that coddle undocumented workers. At hearings on the anti-sanctuary law, anti-immigrant forces cited the city's Executive Order 116 and police policy 104.52 as proof that Denver is soft on undocumented foreigners moving into the U.S. labor force. Nothing we've ever written or said to police officers ever suggested they shouldn't cooperate completely with the federal government in every way they possibly can (Spencer, 2006, p. B1).

"The new law is applicable only to arrestees," said Denver Assistant City Attorney David Broadwell (Spencer, 2006, p. B1) ${ }^{208}$ Local law enforcement officers already notify federal officials when suspected illegal immigrants are in custody. "It would be

\footnotetext{
${ }^{207}$ In 2007, out of the many thousands of foreign-born arrestees who went through the Denver city-county jail, only 2,088 were referred to ICE according to reports filed with the state Department of Local Affairs (Richardson, 2008). The city did not track such statistics before 2006 (Spencer, 2006; Osher 2010f).

${ }^{208}$ The new law says "a peace officer who has probable cause that an arrestee for a criminal offense is not legally present in the United States shall report such arrestee to the United States Immigration and Customs Enforcement office if the arrestee is not held at a detention facility. If the 'arrestee' is in jail, the sheriff must report to ICE" (Spencer, 2006).
} 
much more problematic if it sent local law enforcement out to hunt down illegal immigrants," he told reporters. "We've looked at our provisions and don't think they violate the letter or the spirit of the (new) law" (Spencer, 2006, p. B1).

In October 2008, retiring Colorado congressman Tom Tancredo calls Denver a “sanctuary city" again. The Republican called on Gov. Bill Ritter to cut Denver's government funding because it's a "sanctuary city." Tancredo said in a letter to Ritter that law enforcement has failed to implement laws against illegal immigration and is not referring suspected illegal immigrants to ICE as law requires (Villa, 2008). In 2007, congress passed Tancredo's amendment to the Department of Homeland Security appropriations bill. The law withholds federal emergency services funding from sanctuary cities that protect illegal aliens. ${ }^{209}$ The amendment does not include a definition of "sanctuary city." Ritter spokesman Evan Dreyer called Tancredo's letter a "political stunt" to distract attention from the slumping economy (Villa, 2008).

Tancredo was not the only anti-immigrant foe City Hall battled in 2008. A group led by Dan Hayes, called Denver Future, initiated a petition drive for an ordinance requiring police to impound cars driven by unlicensed drivers and "illegal aliens" (Schroyer, 2008). Hayes claimed stories in the news about unlicensed drivers causing fatal accidents and escaping motivated him to act. But Hayes was not concerned with just any unlicensed driver. "It's all these illegals driving around with no identification," he said in a press interview (Maher, 2009, para. 3), and then added this:

\footnotetext{
${ }^{209}$ Tancredo offer similar amendments at least seven times since 2004 and all failed.
} 
Denver is a mecca of all these problems. All our politicians want is cheap labor. They roll out the red carpet for them. In the case of Denver, which I think clearly is a sanctuary city, all they're getting is a small court fine and are allowed to walk out the door. If they don't give police an ID, no one can prove they're an illegal alien. So these people get off the hook. It's unfair! (Maher, 2009, para. 4).

While enforcing federal immigration laws is not the jurisdiction of municipal police, enforcing traffic laws is. That is what inspired Hayes to launch the petition drive. "All you can do is take their car away and put the burden of proof on the driver," he explained. "If you can't come in and prove you're a citizen with a license, then you should lose your car" (Maher, 2009, para. 5).

The proposed ordinance states: "Unlicensed drivers including illegal aliens are not eligible for auto insurance and pose a significant danger to the people of the city and county of Denver when driving and must be prevented from doing so in every way possible" (Osher, 2008a, p. A15). The measure would require the city to impound vehicles operated by unlicensed drivers. Release of a vehicle would require a $\$ 2,500$ bond to ensure that no unlicensed driver would drive the vehicle for one year. A $\$ 100$ impound fee also would have to be paid (Grenoble, 20011).

Denver-area immigrants' rights advocates said the proposal would chill relationships between immigrants and police. "The more the police are forced to play an immigration function, the worse the situation is going to get," said Lisa Duran of Rights for All People (Osher, 2008a, A15). ${ }^{210}$ The Colorado legislation enacted a law in 2006,

\footnotetext{
${ }^{210}$ Rights for All People is a Denver nonprofit that advocates for immigrants' rights.
} 
which requires identification for anyone applying for state and local services. It had already caused tensions between police and immigrants, Duran told the Denver Post (Osher 2008a).

Councilman Doug Linkhart said the impound proposal was aimed at intimidating unauthorized immigrants, who are not allowed to get driver's licenses. "It's one more punishment for being here that is totally unnecessary and very punitive," Linkhart said in a press interview (Osher, 2008a, p. A15). "I think it could lead to a lot of profiling and discrimination, and people will be stopped for looking like an immigrant" (Osher, 2008a, p. A15).

Bruce Wright, a petition organizer, denied that the effort targeted immigrants. Drunk drivers who have lost their licenses would be the ones affected he stressed (Osher 20081). "I don't think its discrimination against Mexicans or Indians or people from Asia or Japan or anything like that," Wright told the Post. "But you don't belong behind a wheel if you don't carry insurance and you don't have a valid driver's license, period" (Osher, 2008a, A15). Wright told reporters that he did not own a car and lives in housing provided by the Colorado Coalition for the Homeless. He did admit that undocumented immigrants would be affected. "If they're not here legally, they need to be deported back to their country," he said. "You're damn right, they do" (Osher, 2008a, p. A15).

In April 2008, backers of the ballot measure gathered enough signatures to put the item on the ballot if city council members choose not to adopt it (Osher, 2008b). The council's safety committee, led men Councilman Linkhard, planned to discuss the 
Initiative 100 (I-100) in early May. In the meantime, the initiative stirred opposition from Mayor John Hickenlooper, a majority on the Denver City Council, religious leaders and advocates for immigrants (Osher, 2008b).

Councilman Lopez joined a coalition of religious leaders to urge a "no" vote on I-100. The group announced its opposition to the "discriminatory" ballot measure on the steps of the City and County Building in late July (Draper, 2008, p. B1). Rev. Andrew Simpson, vice president of the Colorado Council of Churches, called the measure "dehumanizing" (Draper, 2008, p. B1). Lopez called the measure was unnecessary; driving without a license is already against the law in Denver. It also "establishes a sense of fear in our community," he said. "It does nothing to improve public safety" (Draper, 2008, p. B1).

Later that same week, Mayor Hickenlooper called a news conference to express opposition to the initiative and urge voters to defeat it. Flanked by religious leaders at the St. Francis Center, he said the measure would create an unfunded mandate that could cost the city more than $\$ 1$ million dollars annually and create a bureaucratic nightmare (Osher, 2008c). Existing city ordinances already give police the right to seize vehicles for a host of reasons, including those operated by unauthorized immigrants, Mr. Hickenlooper pointed out (Osher, 2008c). Initiative 100 would impose additional requirements of showing proof of citizenship or legal immigration status in the United States. He said that could lead to racial profiling, as well as burdening police with time consuming paper work. It was a bad idea that would divert precious resources away from more important problems, the Mayor told reporters (Osher, 2008b; Osher 2009). 
Registered voters also receive calls of opposition from Capt. Frank Gals, president of the Colorado Fraternal Order of the Police (Osher, 2008d). A Denver Post editorial claimed the measure would hurt the "city's tourism business as well as our reputation for basic fairness" (Vote 'No',' 2008, B10). Post editors called on Denver residents to "go out in force and vote "no"” on the measure (Vote 'No'," 2008).

The following week (August 1, 2008), the Denver City Council voted 10 to 1 to oppose the ballot measure. ${ }^{211}$ Besides hurting the city's unauthorized residents, the car seizure plan could violate the rights of all minority citizens and burden Denver taxpayers, the council reasoned (Draper, 2008). In a memorandum sent months earlier, Assistant City Attorney David Broadwell warned the council that such impoundments would violate constitutional protections against unreasonable seizure (Vote 'No'," 2008). Councilwomen Jeane Faatz refused to support the proclamation (Draper, 2008).

Despite all of the official opposition Hayes's controversial proposal passed with 53.5 percent of the vote (Maher, 2009; Osher, 2009). The election outcome surprised many of Denver's top civic, political and religious leaders. Initiative supporters did no formal campaigning. They relied on word of mouth alone, and the argument that I-100 would get dangerous drivers off the road and drive down insurance rates (Osher, 2008c). Councilman Rick Garcia, who co-chaired the effort to defeat the initiative, said opponents got a late start. The "campaign to sway voters to defeat the proposals had not kicked into high gear until well after absentee ballots had been mailed in," a Denver Post reporter pointed out (Osher, 2008c, B1). Garcia added that Mayor John Hickenlooper did not as stump strongly for defeat has he had done on other issues in the

${ }^{211}$ Councilmen Charlie Brown and Chris Nevitt were absent (Draper, 2008). 
past (Osher, 2008c). Dan Hayes, who lead the campaign to pass I-100, called the win a "big blow to the City Council," which he said "is clearly working for illegal immigrants and has no clear idea about safety and making the city a safer place" (Osher, 2008c, B1).

After the election, Denver city officials evaded the new impound rule. They did not require police to impound cars of unlicensed drivers (Osher, 2008e). Before police were slated to start enforcing I-100 (in December 2008), Assistant City Attorney David Broadwell's office found discrepancies in the language of the law that allowed the city to legally ignore the main intent of the initiative. "The actual language of I-100," Broadwell explained in his memo, "did not change the basic principle that the police have discretionary authority" on when cars get towed (Osher, 2008e, B1). The city enforced other provisions of the initiative that kick in once the car gets to the impound lot, like the $\$ 2,500$ bond that vehicle owners have to post before getting their car back (Osher, 2009 \& 2010b). A spokesman for Mayor Hickenlooper, Revekka Balancier, told reporters that those pushing for I-100 intended to make such impounds automatic, but legal analysis does not support that (Osher, 2008e). According to the Denver Post, the city attorney's memo advised that: "the actual language of the ordinance, not the language of the ballot question, controls the interpretation of the law now that it has been adopted by voters" (Osher, 2008e, p.B1).

The author of the initiative, Dan Hayes, said he would challenge the city attorney's decision. "Obviously, they're not interested in public opinion," he concluded (Osher, 2008e, B1). In 2009, Hayes and his Future Denver Committee managed to place 
another measure on Denver's ballot--Initiative 300. It attempted to shut the loophole in the new impound rule. The proposed measure amended the wording of the original initiative so that police would be "hereby commanded" to "immediately" impound a car driven by any person who cannot show a valid license (Maher, 2009, para. 11).

Dozens of community groups campaigned against Initiative 300 (I-300), including the Colorado Progressive Coalition, the Colorado Association of Chiefs of Police, the Anti-Defamation League, the Denver Area Labor Federation, the Interfaith Alliance, Metro Organizations for People, and even the Libertarian Party of Colorado (Maher, 2009 ). According to the Westword News:

Nearly every Denver politician - everyone from state senators to school board candidates--declared their opposition; Hickenlooper recorded a robocall urging voters to reject the 'deceptive' measure that would cost the city $\$ 1.2$ dollars in 'unintended' costs (Maher, 2009, para. 14).

In 2009, Denver voters rejected Initiative 300 by an impressive margin, with nearly 7 out of 10 voters rejecting it (Osher, 2010b). Council members Paul Lopez and Doug Linkhart determined voter's strong opposition to the mandatory impound ordinance justified council action to repeal it (Osher, 2010a). Lopez worked with the city attorney's office to draft a repeal of the measure. He brought a proposal to the council's safety committee in early April 2010 (Osher, 2010a). The move infuriated initiative supporters. "They are in bed with the open border people, who are the real ones against this initiative," Dan Hayes said about Denver officials. "They can call me racist, but [I-100] is really about traffic safety" (Osher, 2010a, p. B8). 
During the meeting, López and Linkhart argued that new bonding requirements and fees prompted people to abandon their cars at impound lots, which, in turn, clogged up the system and caused police to tow fewer cars resulting in fiscal problems. The city is losing money. "The only fix is to repeal this," López argued (Osher, 2010b, B2). Council member Jeanne Faatz disagreed. She said budget officials had advised that creating another impound lot would free up space for more cars and turn the program into a profit generator (Osher, 2010b). She added that she did not feel sorry for those without driver's licenses who have trouble posting the bond and paying the fees after getting their cars towed. "When you talk about the costs, it's hard to have sympathy for someone who continues to break the law and flouts the law," Faatz said. "This was intended to say, 'Enough is enough'” (Osher, 2010b, B2). Council members voted 7 to 2 out of committee to the full council for a public hearing and vote (Osher, 2010b). ${ }^{212}$

Councilman Paul López backed away from his push to have the City Council repeal Initiative 100 a week later (Osher, 2010c). Mayor John Hickenlooper made it clear he wanted voters to decide the issue instead of the council repealing the measure (Meyer, 2011). The mayor explained his position in a press interview:

I think once the voters pass something, we have to be diligent in supporting their intentions. And on occasion, if the voters pass something and don't realize what the real consequences are, it's not a bad idea to put it in front of the voters and let them reconsider. But I don't think we should reconsider for them (Osher, 2010d, p. para. 5).

${ }^{212}$ Those voting in favor of the repeal were Council President Jeanne Robb and members Nevitt, Montero, López, Linkhart, Michael Hancock and Carla Madison. Jeanne Faatz and Charlie Brown dissented. 
With his gubernatorial campaign now underway, Hickenlooper also informed council members that he might not be as heavily involved in the campaign against I-100 this time around (Osher, 2010d).

In July 2011, the Denver City Council voted 9 to 1 to repeal the controversial impound ordinance (Navratil, 2011). ${ }^{213}$ Before the vote, Councilman Paul López pointed out that Denver's charter allows councilors to rescind measures approved by popular vote with a super-majority of nine votes by the city council (Navratil, 2011). According to Fox News Latino, the decision to abolish I-100 was made because Denver's new mayor, Michael Hancock, would take office in a few days, and the new councilors elected last year would be instated (“Denver Repeals Ordinance," 2011). Fear of a legal action also prompted council action. Initiative 100 explicitly mentions "illegal immigrants" and includes a definition of such. It does not include any provision for people proving they are not in the U.S. illegally. City attorney Broadwell supported the arguments of López (“Denver Repeals Ordinance," 2011). Even before the I-100 issue was settled, another attempt to conscript local law enforcement officers into taking on immigration duties came about. This time it was in Arizona.

The debate over Arizona's tough new immigration law (S.B. 1070) spilled into Denver in April 2010. Denver Public Schools' superintendent, Tom Boasberg, was the first to respond. He announced a ban on work-related travel to Arizona for all district employees (Marcus, 2010). "This legislation is an assault on human dignity and our core values," Mr. Boasberg said in a message posted on the district website (McWilliams, 2010, p. A1). "We will not put our employee at risk of arbitrary and potentially

${ }^{213}$ Three council members were absent. 
discriminatory harassment that can now occur in Arizona as a result of this reprehensible identity-document legislation" (McWilliams, 2010, p. A1). Boasberg encouraged other school districts and organizations to enact similar bans. Students from Denver schools (middle school to college) staged a walk-out and rally at the State Capital to protest against the Arizona law (Roberts, 2010).

While not planning a similar travel ban, Mayor John Hickenlooper told the Denver Post that he agrees with the DPS action (McWilliams, 2010). "Arizona's law is troubling," he said in a statement. "But I am not surprised states are trying to address immigration policy, because Congress hasn't' (Crummy, 2010, p. A1). The Democrat gubernatorial candidate added that he would veto an Arizona-style law if elected (Crummy, 2010).

Amnesty for unauthorized immigrants and deportation raids

In the meantime, thousands of people swamped Denver streets to protest Arizona's SB1070. Organizers claimed nearly 10,000 joined the May 1, 2010 march; Denver police refused to give a crowd estimate (Espinoza \& McWilliams, 2010). Denver Councilor Paul López, who headed up the march, told KDVR-TV reporter Jon Bowman (2010) this: "We just want President Obama to keep his word...We will see more states follow Arizona's lead if the federal government doesn't come up with a comprehensive immigration plan." City Councilman Doug Linkhart also attended the event (Espinoza \& McWilliams, 2010). 
Ten days later, the Denver City Council issued a proclamation calling for federal action on national immigration reform. The council approved the proclamation 9-1, with Councilwoman Jeanne Faatz providing the lone no vote (Osher, 2010f). ${ }^{214}$ The decree states that any reforms enacted should include "robust border control" as well as "a path to earned legalization, citizenship and social integration for our existing immigrant workforce and their families." ${ }^{215}$ It also calls for any new legislation to provide equitable access to higher education for immigrant students already being educated in American public schools.

Councilmen Paul López and Chris Nevitt introduced the proclamation (Roberts, 2010). "We cannot continue to allow people to be exploited or for good people to live in fear," López argued. "That is not what we are about in this country" (Osher 2010f, B2). Denver representatives Sen. Michael Bennet and Rep. Diana DeGette also spoke in favor of the statement (Osher 2010f). Faatz said she opposed the proclamation because it supported a "path to citizenship" for those "who have jumped to the front of the line to get into the country illegally" (Osher 2010f, B2). Councilwoman Marcia Johnson summed up the majority view when she said "there was much to dislike" about Arizona's immigration law, but it has made people realize that the federal government needs to act (Osher 2010f, B2). "We cannot do this state by state," Johnson concluded (Osher, 2010f, p. B2). Councilman Nevitt concurred, adding that federal foot-dragging on immigration has resulted in a chaotic enforcement situation for local government, and "crazy stuff"

\footnotetext{
${ }^{214}$ Council members Charlie Brown and Michael Hancock were absent. Hancock sent a letter in support. ${ }^{215}$ PR10-0379, Series 2010 (passed May 10, 2010)
} 
like Denver's I-100 and I-300 (Marcus, 2010). After the proclamation passed, Nevitt told a Westword journalist this:

I understand where the people of Arizona are coming from. I think the way they're dealing with the situation is a huge mistake, but I can't fault them for trying. This simply has to be addressed at the federal level, and myself and Councilman López wanted to make that clear, and to lay out what we'd like to see in comprehensive immigration reform (Roberts, 2010, para. 4).

Colorado Immigrant Rights Coalition (CIRC) applauded the "courageous step" the Denver City Council took in issuing the proclamation (CIRC, 2010). The group opposes Arizona's "show me your paper" policies, which they claim resembles another bill that traps many "low-priority people" in the "deportation pipeline"-Colorado's SB 90 (CIRC, n.d., p.1).

On May 1, 2006, 75,000 protestors marched to the Colorado state capital to oppose "the grandparent of Arizona's S.B. 1070's Section 2(B)"-S.B. 90 (CIRC, n.d., p.1), and draw attention to a bill in Congress that would make it a felony to be in the United States illegally (Archibold, 2007). Former Denver mayor Federico Peña (19831991) was at the rally; the city's current political leadership was not. In his address to marchers, Peña underscored the importance of Latino workers to the national economy:

We should admire them for cleaning our buildings, building our homes, preparing our food, producing our oil, working our mines, cleaning our hotels, mowing our lawns, digging our ditches, and yes, even fighting our wars (Brown, 2006, p. A1).

He called for "compassion and decency" in immigration reform (Simpson, 2006, p. A1). Then, outlined his vision for change which included sanctions for employers who hire unauthorized workers, a guest-worker program and amnesty for illegal immigrants 
already living in the United States (Simpson, 2006). "If Congress has the courage and wisdom to do this, we will not need to build any fences" (Carman, 2006, p. B1).

The following year, at the May Day 2007 march in Denver, Peña again emphasized the need for policy reform and advocated an end to law-enforcement raids (Aguilera, 2007). He told thousands immigrants and their supporters that legislation was needed to normalize the lives of workers terrorized by ICE raids (Aguilera, 2007; Carman, 2007); recent raids in the nearby town of Greeley, other Colorado towns, fueled local anxieties about deportation and its aftermath (Aguilera, 2007). Speaking after the march, Peña said told the Denver Post "the only reasonable, economically feasible solution is for Congress to provide a path for those here illegally to achieve legal status or citizenship..." (Carman, 2007).

A decade earlier, James Mejia, executive director for the City Agency for Human Rights and Community Relations, offered his support to 150 anti-raid activists during a 1998 rally (Duran \& Flores, 1998). INS deportation raids at a local manufacturing firm and roofing company had shattered families and raised anxiety among Denver's lowwage, mostly Latino workers. "Speaking in English and Spanish, Mejia described a new 'Memorandum of Understanding' that the city entered into with the Department of Justice to stop workplace discrimination based on national origin, citizenship and/ or accent” (Duran \& Flores, 1998, p. G3). He reminded AFSC and union representatives about Executive Order 116, that Mayor Wellington Webb issued in March, affirming the City's commitment to protect the rights of immigrants (Duran \& Flores, 1998). 


\section{"Locally legal" identification cards}

In October 2002, without debate or public comment, Mayor Wellington Webb issued Executive Order 119 (CAIRCO. n.d.). It authorized municipal acceptance of Mexican matrícula consular identity card, and encouraged private businesses to so the same (Allott, 2002). By recognizing the cards as acceptable ID in transactions with the city, Webb made it easier for unauthorized immigrants to obtain business licenses, library cards, access to recreation centers and medical services.

Webb made the announcement at a press conference, where he praised the contributions of immigrants and highlighted shifts in Denver's demographic makeup. ${ }^{216}$ The policy, he said, "is a goodwill gesture to a neighboring country and its citizens" who now are part of the Denver community (Riley, 2002e, p. A1). A reliable ID card, he added, would make it easier for police to deal with Mexican nationals, and should cut into the burgeoning illegal trade in fake IDs (Riley, 2002e). The mayor also used the occasion to voice his opposition to Amendment 31 (limiting bilingual education in state schools), and lend support to a movement to protect a Mexican honor student and his family from deportation (Riley, 2002e). ${ }^{217}$

Denver's Police Department began accepting the card immediately. If stopped by police, matrícula-holders can present the ID card just like a Colorado driver's license, Webb told the Denver Post (Riley, 2002e). Days later, after the City Council approved a

\footnotetext{
${ }^{216}$ According to the 2000 Census, the city's foreign born population tripled from 1990 to 2000 largely due to Mexican immigration (Gartner, 2005).

${ }^{217}$ Webb said the high school honor student, who complained about having to pay the out-of-state tuition rate at the University of Colorado at Denver because he and his family were not legal U.S. residents, was wrongly singled out when Rep. Tom Tancredo alerted the INS about his status after learning about him in a Denver Post story (Riley, 2002e).
} 
supporting resolution, other municipal agencies in the Colorado capital followed suit. The Mexican Consulate in Denver, which lobbied local officials to win acceptance for its card, was deluged with ID applications (Reid, 2002f). Long waiting lines at the Consulate office prompted a swift reaction from individuals and groups that favor restrictive immigration.

Rep. Tom Tancredo asked federal agents to stake out the Mexican government office and deport illegal immigrants. The INS rebuffed him, saying that applying for an ID card is not probable cause to suggest that the applicant is an illegal immigrant (Reid, 2002e). So Tancredo tried a different approach. He sent a letter to Mayor Webb urging him to reconsider his decision to allow city agencies to recognize ID cards issued by the Mexican Consulate. "Giving illegal aliens equal and unhindered access to the services of our cities and towns is tantamount to a de facto amnesty granted by local authorities and not authorized by the president or the U.S. Congress," Tancredo wrote (McAllister, 2002, p. A1). Andrew Hudson, spokesman for Mayor Webb, refused "to respond the numerous errors and fallacies in Mr. Tancredo's letter." Instead Hudson told the congressman that his "personal publicity campaign against the nation's Hispanic community has grown beyond offensive" (McAllister, 2002, p. A1).

Denver Post Columnist Al Knight was another critic of the city's new ID plan. He called it an "attempt to create a new class of immigrants, not quite legal but not quite illegal either" (Knight, 2002, p. E5). Michael McGarry, spokesman for the Colorado Alliance for Immigration Reform (CAIRCO), issued this statement about the identification cards: 
Who would have a Matricula card? By definition, they are almost all going to be illegal aliens. The mayor is asking us to give full faith and credit to an amazingly corrupt government. It's absurd that we would put our security and our document integrity in their hands. These are phony, sham cards (CAIRCO, n.d., para.4).

McGarry held a news conference under a "Denver celebrates diversity" sign on the steps of the City and County Building, where he announced his intent to file formal complaints with the U.S. attorney's office and the Immigration and Naturalization Service. He was drowned out by protesters who chanted during his presentation and accused him of being racist (Sarche, 2002). Undaunted, McGarry delivered a letter to the mayor's office alleging the city's ID policy violated federal law. Webb stood firmly by his policies, and declined to criticize his adversaries (McCallister, 2003).

In May 2003, the Colorado legislature passed a law forbidding state and local governments from accepting identification not issued or recognized by state or federal agencies in the United States. The law's most immediate target — the ID card issued by the Mexican government to citizens living abroad. ${ }^{218}$ This came in response to critics who argued the IDs encourage illegal immigration (Quintero, 2006).

After it became illegal to accept the matrícula consular card in Colorado, antiillegal immigrant watchdogs zeroed in on the Denver Public Library (DPL). They accused library officials of trying to skirt around the new state law by accepting a Mexican driver's license as valid identification for use of library facilities and services. Employees do not collect any information from the patrons presenting these "non-secure" and "unverifiable" IDs, critics complained; they just take it (CAIRCO, 2005b). Since no attempt is made to verify the authenticity of a foreign driver's license, it is easy for

\footnotetext{
${ }^{218}$ Colorado HB 03-1224 (Secure and Verifiable Identity Document Act), approved May 22, 2003.
} 
anyone to use a fake driver's license to get full access to the DPL's collection of books, videos and other materials, argued critics.

CAIRCO members went to the library looking for evidence that DPL was accommodating "illegal" immigrants. During their shelf search, members of the selfdescribed "immigrant-reduction" coalition came across a collection of fotonovelas, some of which included sexually explicit drawings. ${ }^{219}$ They reported their findings to Denver radio talk-show host Peter Boyles, who brought the issue to public attention (Aguilera \& Sanchez, 2005; Tancredo, 2006a). He revealed that the Denver Public Library was spending thousands of dollars on Spanish-language pornography books, and was throwing away English-language books to make room for Spanish materials for illegal immigrants. Two months earlier, Congressman Tom Tancredo registered a public complaint about the Library's plan to beef up its Spanish-oriented resources. Boyles added this tidbit to the controversy over the novellas (Aguilera \& Sanchez, 2005).

After learning about the Library's plans, Tancredo sent a public letter to Mayor John Hickenlooper questioning his oversight of the Denver Public Library. He accused the mayor of underwriting the "cultural balkanization" of the community by supporting changes at the DPL, including, among other things, the shift to Spanish-language-only libraries and the practice of coercing librarians to learn Spanish (Aguilera \& Sanchez, 2005; Crummy, 2005c; Gartner, 2005; Tancredo, 2006). Hickenlooper responded with a five-page letter denying each of Tancredo's 12 assertions, and telling him that he "misplaced" his trust in sources who had given him bad information (Crummy, 2005c, p. A1). He also wrote:

${ }^{219}$ Fotonovelas are adult Spanish comic books. 
Because more than 20 percent of all Denver residents speak Spanish at home, the Library is interested in providing additional Spanish-language materials and services, but it is not considering any 'conversion' plan along the lines suggested in your question. English is and will remain the primary language of the Denver Public Library (Crummy, 2005c, p. A1).

Hickenlooper further clarified the role of the Council in library affairs - to approve the Library's budget, not to debate or approve operational matters. ${ }^{220}$

On August 8, 2005, the Coalition for A Closer Look ${ }^{221}$ protested outside the main branch of the DPL to draw attention to its foreign pornography collection. As news cameras rolled the speakers veered off topic to rant about the alleged readers of the books — "illegal” immigrants (Rodriguez, 2005c). After the rally activists marched to the Library to deliver a letter demanding director Rick Ashton's resignation. The letter accused Ashton of accommodating illegal immigrants while "peddling porn" at taxpayer expense (Crummy, 2005e; Rodriguez, 2005c). It also expressed the group's opposition to his "clandestine moves" to establish bilingual libraries with bilingual librarians; a change the Coalition contends would prevent immigrants from assimilating to [European] American culture. English has been the official language of Colorado in since 1998, CAIRCO's Mike McGarry pointed out. It is inappropriate for the library to purchase books in languages other than English (Spencer, 2005b). A copy of the letter was also sent to Mayor Hickenlooper's office (CAIRCO, 2005b).

\footnotetext{
${ }^{220}$ The Denver Public Library is an independent agency, governed by the Denver Public Library Commission, an appointed citizen board designated by the Denver City Charter.

${ }^{221}$ Coalition members included the Colorado Minuteman Project, Sovereignty Colorado, and Colorado Alliance for Immigration Reform.
} 
The Denver Public Library yanked all of its 6,569 novellas from the shelves for an audit, and cancelled four of its fotonovela subscriptions (Richardson, 2005d). Library director Rick Ashton announced his retirement (Crummy, 2005e). A Denver resident can still get a library card with a Mexican driver's license at the Denver Public Library.

\section{Unregulated day labor-contractor market exchanges}

In 1998, a brain injured day laborer was found wandering inner-city Denver near an informal job pick-up site. Earlier he had been hired on this corner for a day's work as a roofer, but was injured by a fall off the roof (El Centro, n.d.). The employer dropped the injured man off at night and sped away. The day laborer never fully recovered. He still shuffles around downtown Denver. The employer was never located (Rinehart \& Robinson, n.d.).

The incident prompted the American Friends Services Committee (AFSC) to reach out to the growing day labor community (AFSC, Denver, n.d.). Large numbers of foreign-born day laborers begin arriving in Denver area in the early 1990s. That was when the housing market took off and industries, like janitorial services, started shifting their workforces to one that was predominately Spanish-speaking immigrant (Simpson 2001; Aguilar 2000a). As the numbers of day laborers increased so did the incidents of labor abuse.

In 2000, AFSC hired Minsun Ji (a former union organizer with Denver's local chapter of the SEIU) to head up its day laborer organizing project, Humanitario Para Los Trabajadores (Rinehart \& Robinson, n.d.). ${ }^{222}$ Pressure was building for day laborers to relocate. A housing development was pushing them out of their traditional staging area,

${ }^{222}$ The Humanitarian Center for Workers became fully independent of AFSC in January 2004. 
and neighbors were starting to complain (Gutierrez, 2002). The idea for a permanent, indoor day labor center came from the workers (Rinehart \& Robinson, n.d.).

El Centro organizers found a site for a hiring center, but were forced to reconsider their plans after opposition from local businesses (Rinehart \& Robinson, n.d.). They eventually found a landlord nearby who was willing to rent to them. ${ }^{223}$ The owner agreed to lease his vacant car repair shop to El Centro for $\$ 2,500$ a month. The group only had two month's rent guaranteed, and no money for staff or building repairs. El Centro turned to Mayor Wellington Webb for help (Riley, 2002b). After hearing their plan, he offered a $\$ 25,000$ grant, enough to rent the building for one year. Council member Elbra Wedgeworth, also contributed to the start-up. She got local businesses to donate supplies to refurbish the El Centro site (Riley, 2002b). The mayor's office received some phone calls from irate citizens who said, "How dare you use city money for these illegals?" said Phil Hernandez, city coordinator for the project. Hernandez corrected callers, pointing out that not all day laborers are illegal. And even if some are, he added, "It's better to monitor their employment contracts rather than ignore them" (Riley, 2000b, p. A1).

In 2001, AFSC asked the City for $\$ 120,000$ a year to run the center for day laborers, but could not get a commitment. In the meantime, the organization continued to donate the staff time of Minsun Ji (Rinehart \& Robinson, n.d). The center opened its doors on June 1, 2002 with volunteer staff and some community funds. Students from Colorado University-Denver's Westside Outreach Center (a service-learning program)

\footnotetext{
${ }^{223}$ The site is located near Broadway and Larimer Street, an area in transition from a haven for the city's homeless to a place with luxury lofts (Riley, 2002b).
} 
staffed the front desk. Felicia Hilton, director of Colorado Jobs With Justice, also put in volunteer hours, as did law students from Denver University (Rinehart \& Robinson, n.d.).

After a year of pressure from organizers, Mayor Web agreed to fund El Centro's annual operating costs at a December 2002 meeting. But the money didn't come in the budget year of 2002 (Kane \& Lingle, 2001; Riley, 2002a; Morgan, 2002). The City Council held things up. Council members worried about community backlash. The city attorney was apprehensive about the legality of funding a site that would serve mostly unauthorized workers (Riley, 2002b\&d). ${ }^{224}$ El Centro has a “don't ask, don't tell” policy about legal status (Gutierrez, 2002). It was a controversial use of funds at a time when money was tight, said Phil Hernandez, director of the mayor's Office of Human Rights and Community Relations. Michael McGarry, president of the Colorado Alliance for Immigration Reform, had already threatened a lawsuit if the city contributed (Riley, 2002d).

"If the city doesn't step up soon, I worry the center won't be able to continue," said City Councilman Doug Linkhart, who attended a fundraiser for the start-up (Shanley, 2004, p. C2). "Without the center, we'd have more people in jail, more on the street and more in hospitals. We need to find funding to make the center more permanent" (Shanley, 2004, p. C2). In 2003, the City Council awarded El Centro a $\$ 344,252$ grant for labor exchange services to cover the period of July 1, 2003 to June 30, 2005 (Ji, 2009). ${ }^{225}$

\footnotetext{
${ }^{224}$ No law specifically prohibits using federal funds for a day laborers' center. However, several federal laws, including the 1986 IRCA (makes hiring illegal workers a crime) and welfare reform legislation passed by Congress in 1996, prohibits using federal funds to provide services to illegal immigrants. So, it's unclear if federal money can be used for a center that facilitates the employment of undocumented workers. ${ }^{225}$ Council Bill No. 918.
} 
The funds came from a federal block grant (Kane \& Lingle, 2001). Horror stories about wage exploitation, and injured day laborers getting dropped off at the nearest emergency room to fend for themselves, motivated officials to act. It is those abuses that the center is meant to combat, explained Minsun Ji, the director of El Centro (Rinehart \& Robinson, n.d.).

In 2005, Denver became the third U.S. city to provide legal and police protection for day laborers cheated out of their wages (Aguilera, 2005d; Valenty, 2006). ${ }^{226}$ The City Council unanimously passed a local wage theft law in December. ${ }^{227}$ The ordinance amended the city's Municipal Code, adding nonpayment of "wages for labor" under $\$ 500$ to a list of prosecutable offenses. Wage theft over $\$ 1000$ is illegal under Colorado law. But the statute leaves most day laborers, who are often owed less than $\$ 500$, out of the loop. Denver's new ordinance addresses this uncovered area of labor abuse (Aguilera, 2005d). ${ }^{228}$ It also gives day laborers recourse when they are cheated (Valenty, 2006). Under the new law, unpaid workers can contact either El Centro or other labor advocates tied to church or community groups. If advocates cannot resolve the case, it is referred to the Denver police, who have the authority to arrest predatory employers and pursue civil and criminal penalties.

\footnotetext{
${ }^{226}$ Austin, Texas, was first in 2002, followed by Kansas, City (Aguilera, 2005d; Valenty, 2006).

${ }^{227}$ Revised Municipal Code City and County of Denver, chapter 38, article III, sec. 38-51.8.

${ }^{228}$ Until July 1, 2007, theft amounting to less than $\$ 500$ constituted a violation of the Denver ordinance. Then Colorado state law covered intentional theft amounting to more than $\$ 500$. When the Colorado Legislature revised state law to cover only amounts of $\$ 1000$ and more, effective July 1, 2007, then the Denver ordinance was revised to cover amounts under $\$ 1000$.
} 
Councilman Doug Linkhart introduced the proposal. “I don't like the face that there are businesses out there that over and over again hire people and intentionally don't pay them," he said in a press interview (Aguilera, 2005d, p. B3). "If someone steals a wallet, the police can come and arrest you. But if you don't pay (a person), the police can't do anything," Linkhart told a Los Angeles Times reporter (Valenty, 2006, para. 8). Inundated with complaints about wage theft, El Centro and its coalition partners spearheaded the end-wage-theft campaign to persuade the City Council to passage the new ordinance. Stakeholders met for more than a year to research solutions and draft the law. The group included representatives from the City Attorney's Office, Denver Police Department, State Department of Labor, El Centro staff and volunteers, and Councilman Linkhart (Linkhart, 2009).

Even though it is day laborers who are most often the victims of fraud, backers of the law pitched it to the Denver City Council as a measure that would protect all workers. The proposed ordinance "would make any amount of wage theft a crime and provide protections for all workers, regardless of citizenship," Linkhart said (Aguilera 2005c, B1). Still, this ordinance is not about citizenship status, Linkhart added. It's about supporting basic worker rights (Aguilera, 2005d). "I support basic workers rights," said Councilwoman Judy Montero. "If they work the hours, they should get paid" (Aguiler, 2005d, p. B3). "Working with the Police Department is going to make a huge difference," Ji said after the ordinance passed (Aguiler, 2005d, B3). A short time later, the owner of the warehouse donated the building to El Centro (Rinehart \& Robinson, n.d.). 
Not everyone has been supportive of the day labor center. Representative Tom Tancredo threatened to sue the city of Denver for supporting El Centro's work with undocumented immigrants. Colorado Minutemen and CAIRO) activists tried to intimidate Mayor Hickenlooper at a December 2005 capital campaign fundraiser for El Centro Humanitaro para los Trabajadores. He was the keynote speaker (CAIRCO, 20052006). The coalition was incensed that the city-supported day labor center helps "illegal" aliens find work. Activists berated the mayor and other El Centro supporters (Rinehart \& Robinson, n.d.; Rodríguez, 2005d).

In January 2006, about fifteen anti-illegal immigrant activists picketed in front of the center as part of the national "Stop the Invasion" protest against undocumented workers (Crummy, 2006). "They're invading our country," said Eric Tavares, one of the protesters outside the center. “They want jobs, free health care. I don't want my country turning into a Third World hellhole" (Crummy, 2006a, C1). Minsun Ji, executive director of the day labor center, set up a counter rally to stand up for the vulnerable workers. More than 200 immigrants' rights supporters showed up (Kim, 2006a). El Centro opponents have also tried to shut El Centro down by videotaping license-plate numbers of employers, as well as businesses and centers assisting day laborers. Their video is posted on the Colorado Minutemen's website (Crummy, 2006a). "Targeting places like El Centro that focus on workforce development for low-wage earners doesn't solve anything," Hickenlooper said through a spokeswoman (Kim, 2006b, para. 17). Solutions need to come from Washington, he concluded. 
As the issue of immigration became more politicized (in 2005 and 2006), Denver's only day labor center struggled. Several foundations grew hesitate to continue their support. The City, however, continued to fund El Centro's work with substantial grants and public recognition efforts (Rinehart \& Robinson, n.d.). At the organization's third anniversary celebration, Mayor John Hickenlooper made these remarks:

El Centro's legal employment and education programs have helped countless individuals in acquiring the skills necessary to be productive members of our community. As Denver's only non-profit dedicated to the protection of immigrant day laborers, El Centro services are a valued partner in protecting the human rights of all our citizens (Rinehart \& Robinson, n.d., p. 22).

In 2006, the Denver Women's Commission honored El Centro with its community service award for its excellent work serving low-wage women (Rinehart \& Robinson, n.d.). The following year, Denver's City Council issued a proclamation recognizing the fifth anniversary of El Centro Humanitario Para Los Trabajadores. ${ }^{229}$ It acknowledges the nonprofits efforts to "protect human rights and keep day laborers safe and protected from exploitation and dangerous working conditions." It also reaffirms the city's commitment "through policy and financial assistance to maintaining and enhancing the services that El Centro Humanitario provides."

\section{Asylum for unauthorized refugees}

Local government in Denver took no public stand on the Central American asylum issue. Immigration was not on the city's agenda before the 1990s. Its foreign-born and ethnic minority population was numerically insignificant.

\footnotetext{
${ }^{229}$ Proclamation No. 51, Series 2007.
} 


\section{City Profile}

Portland, the most populous city in Oregon, is near the coast between Silicon Valley and Seattle. It has been called the last Caucasian Bastion in the United States, ${ }^{231}$ and a bastion of everything hip (Harris, 2012). In the twentieth century Portland was a gateway for immigrants from Germany, Scandinavia, Canada and the British Isles (Hardwich \& Meacham, 2008). A legacy of Black and Asian exclusion laws, coupled with the political influence of the Ku Klu Klan in the 1920s, helped turn Portland into the whitest big city in the nation (Turnbull \& Mayo, 2011). After waning mid-century, Portland re-emerged as an attractive destination for refugees and immigrants in the 1990s. The foreign-born in the city more than doubled between 1990 and 2000, accounting for 12 percent of the total population (Brookings Institution, 2003). Thirtyeight percent came from Asian nations, while Europe and Latin America each added onequarter to Portland's foreign-born; many are refugees (Hardwich \& Meacham, 2008). ${ }^{232}$ This demographic change helped diversify Portland.

At the same time, the city's livability and robust job market in the 1990s made it a magnet for domestic migrants as a well. More than a quarter of Portland's residents lived elsewhere five years prior. Portland was also a top gainer of young (25- to 34-year-old) creatives due to its "cool city" vibe and DIY culture (Frey, 2011). The native-born

\footnotetext{
${ }^{230}$ U.S. Census, 2010.

${ }^{231}$ Kaplin's 1998 characterization in the Atlantic Monthly of the Pacific Northwest.

${ }^{232}$ Portland was the twelfth largest receiver of refugees during the period. The largest refugee groups residing in Portland are white, Protestant European groups (born in Russian and the Ukraine).
} 
moving into the city have been mostly nonHispanic white, while nearly 10,000 people of color, mostly African Americans, have been gentrified out (Hahha-Jones, 2011). The city today has nearly equal populations of black, Asian, and Latino residents, who together represent 28 percent of all Portlanders (up from 20 percent in 2000). Despite small gains in diversity, Portland is a city that prides itself on tolerance, social equity and nonconformity.

Portland has a well-educated workforce (39 percent of Portlanders have a bachelors degree), and a sustainable, diversified economy. Its economy consists of primarily small businesses (in the retail trades and service sector) and is anchored by a strong manufacturing base. Portland is also the hub for high-technology industry, the largest of these is Intel. The city's economy flourished in the 1990s due to exportoriented manufacturing. Despite these strengths "there remains a polarization between high-skill and low-skill sectors which makes it hard for new arrivals to find employment that pays them enough to survive" (Hardwich \& Meacham, 2008).

Still, Portland is the most affordable city on the West Coast. It has been called "the poor person's Bay Area" (Abbott, 2001, p. 93). In 2000 the media value of housing was $\$ 154,900$. Affordability rates, however, are declining. Portland in the 1990 s had a tight market for new households and working class residents. Although real per capita income in the city is above the national average, housing affordability is now a major problem (Gibson \& Abbott, 2002). 
The city of Portland has the last remaining Commission form of government among large cities in the United States. The Mayor, four Commissioners and the Auditor comprise the city's six elected officials. The Mayor and the Commissioners together make up the City Council. The commission form of government differs from most other municipal governments in that its members have legislative, administrative and quasijudicial powers. Community-based participation in all aspects of government planning and administration is an established part of the political culture of Portland. In comparison to other cities, Portland ranks high in citizen involvement (Abbott, 2001). Middle-class Anglo citizens participate more than lower-income racial and ethnic minorities (Johnson, 2004). City \& state law give Portland citizens the ability to initiate legislation through the initiative petition process, or to refer legislation passed by the city council to a vote of the people through the referendum petition process. Portland is a liberal-leaning city. In a nationwide study of the most conservative and liberal cities in the United States, Portland ranked 29 (out of 237 cities) on the liberal list (BACVR, n.d.).

\section{Unauthorized Immigration Policy}

Federal efforts to enlist the Portland Police Bureau in the enforcement U.S. immigration law has been the most hotly debated issue in Portland, though the city has flip-flopped on its position. The conduct of Portland's INS district office also generated a fierce reaction. Controversy over the day labor dilemma was long-running, but less intense than the other two issues. The same goes for ICE deportation raids. The matters of taxpayer-supported public benefits for foreign in-migrants, and Mexican ID cards, were nonissues in Portland. Asylum made it on the local political agenda for a day. 


\section{The devolution of immigration law enforcement}

Antagonism marked early relations between law enforcement and foreign inmigrants. For years Portland police and the INS worked together sweeping places where immigrants lived and worked, apprehending those without documents (Bjorhus, 1997; Daza, 2002b). That changed after the August 4, 1992 raid at the former Galaxy Apartments, a complex with a high concentration of low income Latino tenants (Rede, 1992a; Bjorhus, 1997). Police and federal immigration agents went to the apartment complex looking for undocumented immigrants. They arrested 26 Latino men. Neither agency had a warrant. Police found no drugs or weapons. They did not file a report. Criminal charges were never pursued against any of the men, who were eventually deported (McVea, 1992a\&d; Griffin, 2007a). Witnesses said officers overstepped their "peacekeeping role" by knocking on doors and ordering residents out into the courtyard where immigration officials arrested them. ${ }^{233}$

Afterwards, a spokesman for the Portland Police Bureau (PPB), Sgt. Derrick Foxworth, issued a statement. "Our role is not to enforce INS violations but to ensure the safety of citizens and INS agents," he told reporters (McVea, 1992e, p. B3). Foxworth mentioned that if citizens filed complaints, the Bureau would look into whether its officers should help immigration agents conduct deportation raids in the future.

\footnotetext{
${ }^{233}$ In an August 25, 1992 memo to precinct manager, Chief Potter said, "peacekeeping" is defined here as providing a presence to ensure that no crimes are committed while performing lawful duties" (McVea, 1992c).
} 
A week later, then-Police Chief Tom Potter met with Latino community leaders to talk about the raid. ${ }^{234}$ The group accused the PPB of racial profiling, violating the principles of community policing, and breaking Oregon's 1987 immigrant protection statue (McVea, 1992c; Rede, 1992a; Bernstein, 2001a\&c). ${ }^{235}$ The law bars state and local law enforcement agencies from using resources to look for, arrest, or detain people whose only crime is being in the country illegally. ${ }^{236}$ Potter said bureau policy had not been updated since the law was passed in 1987. He invited, Angel Lopez, the criminal defense lawyer who brought up the issue, and other Hispanic community representatives to join with the police and city attorney's office in clarifying what officers can and cannot do at deportation raids. Potter said he wanted a new policy that "not only conforms with state law (but) does nothing to inhibit our relationship with the Hispanic community" (Rede, 1992c, p. C6). Both sides agreed to meet the following month to review the recommended changes.

In the meantime, Potter promised to issue a temporary directive that precinct commanders must approve all police bureau operations in conjunction with the INS. He also agreed to investigate claims that Portland police routinely stop Hispanics to inquire about their legal status. Community representatives offered to submit a list of people that police could call on to help with cultural awareness and sensitivity training. Potter was receptive to the idea, and reaffirmed his commitment to hire more bilingual officers

\footnotetext{
${ }^{234}$ Potter served as chief from 1990-1993.

235 OR. REV. STAT. § 181.850 (1987).

${ }^{236}$ According to Rocky Barilla, a former Democratic state representative who sponsored the bill, the law was inspired by a series of incidents in which police used immigration status--a civil matter--as an excuse to question Latinos and foreign students whom they otherwise had no reason to suspect of criminal activity (Green \& Bernstein, 2001).
} 
(Rede, 1992c). He invited the group to review the bureau's minority recruitment plan. Both sides pledged to work together to rebuild public trust in the Police Bureau damaged by the August 4 raid (Rede, 1992c). The tone of the 75-minute meeting was largely conciliatory.

The next day, Potter made good on his promise. He issued a memorandum to precinct managers that spelled out the limitations of their "peacekeeping" role during deportation sweeps. The August 25 memo stated: "Officers will provide a 'peacekeeping' presence only at places where arresting Immigration and Naturalization Service agents expect violence. This means we will take no action to assist the INS in the performance of their duties unless a crime has been committed" (McVea, 1992c, p. B4). The message was circulated at a morning meeting of the Chief's Forum. Potter also reminded officers that they may not detain motorists or pedestrians simply to check immigration status. A Galaxy Apartments resident, who was present when the raid took place, complimented the Police Bureau for Potter's memo. "I think it's pretty good," Amelia Hernandez told reporters. "They are here to protect us, not make things worse" (McVea, 1992 c, p. B4). Later, Chief Potter updated bureau policy so it conformed to Oregon law (Green \& Bernstein, 2001). The new policy spells out cooperation between police and the U.S. Immigration and Naturalization Service in Portland. ${ }^{237}$ Officers cannot ask about the immigration status of victims or witnesses of crimes, or detain motorists or pedestrians simply to determine if they are legally in the country. Police supervisions must also approve any INS requests for help with immigration raids, and will not set up perimeters or arrest any non-criminal aliens. The police will still notify the INS when they make a

${ }^{237}$ Policy (810.10) Arrest of Foreign Nationals (PPB Manual of Policy and Procedures, 2001). 
criminal arrest if the person turns out to be an unauthorized alien (Bernstein, 2001a; Griffin, 2007a). The changes, the Chief said, were designed to address complaints by Latinos who felt that police discriminated against them by stopping them only to ask about their immigration status. "We feel this policy is not only good public policy, but it takes into account the partnership we have within our community to include the Hispanic community," Potter told a reporter for the Oregonian (McVea, 1992c, p. B4).

In drafting the new policy, the Chief relied heavily on suggestions from Portland Police Bureau's Hispanic Advisory Council. ${ }^{238}$ Latino leaders praised Potter for his willingness to listen to community concerns. They said the new policy would help rebuild Latino community trust in the Police Bureau that was damaged during the Galaxy Apartments raid (McVea, 1992c; Bernstein, 2001c). Oregon's congressional delegation called the new policy a national model (McVea, 1992e).

Responding to objections from the Hispanic community, in March of 1993, Portland police asked the district INS chief to remove an agent who had been assigned to work with officers to curb drug dealing in Portland's Old Town district (McVea, 1993). In 1994, the PPB also ended its short collaboration on the Interagency Gang Enforcement team (Ortiz, 1994; Pulaski, 1997). ${ }^{239}$ The change was a response to immigrant rights'

\footnotetext{
${ }^{238}$ This 10-year-old community-based police advisory committee--comprised of Hispanic community representatives and more than a dozen local, state and civic organizations--was "originally formed out of concerns about police-INS cooperation on raids on migrant camps in the early 1980s" (Ortiz, 1994; Bjorhus, 1997).

${ }^{239}$ In 1993, an INS agent was assigned to the Portland Police Bureau's Central Precinct, "after Congress called for more INS agents to help Portland's Tar Heroin Task Force crack down on illegal sales of the drug" in Old Town. Many of those arrested in this area for drug dealing are illegal immigrants (McVea, 1993).
} 
group claims that drug and gang operations were a thin guise for rooting our undocumented immigrants (Bjorhus, 1997). Still, this did not end collaborative arrangements between the Portland Police Bureau and federal agents.

Portland joined the FBI's Joint Terrorism Task Force (JTTF) in 1997, to prevent potential terrorist threats at the Nike World Masters Games (Schmidt, 2011a). Early decisions about the partnership went unnoticed. But after the police watchdog group Portland Copwatch brought it to the public's attention in 2000, the ACLU and its coalition partners mobilized to reverse the City's decision to participate in the JTTF (Helegers \& Mercier, 2002). ${ }^{240}$ At the first public Portland JTTF hearing in September 2001, activists jammed the chambers of the city council to make their pitches about the FBI's long history of repressing political dissent. They argued against Portland's continued participation in the JTTF because the state's anti-McCarthyism law prohibited it (Green \& Bernstein, 2001). ${ }^{241}$ The law prohibits state and local law enforcement agencies from collecting or maintaining information about individuals, groups, or associations unless the information directly related to criminal activity, or there are reasonable grounds to suspect the individual may be involved in criminal conduct. ${ }^{242}$

But after five hours of heated testimony, the Portland City Council voted 4-1 to keep officers in the task force. Critics walked out as politicians tried to explain (Attig, 2001; Hellegers \& Mercier, 2002; Hellegers, 2005; Schmidt, 2011a). Still the mayor and

\footnotetext{
${ }^{240}$ Dan Handelman, of Portland Copwatch, noticed an item related to the JTTF on the City Council's agenda (Hellegers \& Mercier, 2002).

${ }^{241}$ OR. REV. STAT. § 181.575 (2001).

${ }^{242}$ The law, introduced in the 1981 legislature on behalf of Associated Oregon industries, started as a bill to allow employers to obtain background information on prospective employees. But after the ACLU challenged it, the legislature added language to prohibit police from collecting or maintaining information about the political, religious or social views of individuals or groups (Green \& Bernstein, 2001).
} 
police chief signed a contract pledging vigilant police oversight to ensure that the statute would not be breeched (Green \& Bernstein, 2001). Dan Handelman, of Portland Copwatch, later weighed in on the police department's record:

They promised the community that the Portland-FBI Joint Terrorism Task Force would not violate these laws, and they have followed through. That's very heartening. In a rare case we're being supportive of the city and police here (Green \& Bernstein, 2001, p. A1).

The city further solidified its position on local cooperation with federal agents when the PPB became the first city agency in the nation to publicly refuse to participate in post 9/11 anti-terrorism investigations in 2001 (Learn, 2001). When U.S. Attorney General John Ashcroft ask the PPB to interview Middle Eastern visitors in Portland on visas, red flags went up (Learn, 2001; Hellegers, 2005). Andrew Kirkland, Portland's acting police chief, consulted with Deputy City Attorney David Lesh, who advised him not to comply with the request. Kirkland told $C N N$ that his agency could not comply with the U. S. Justice Department because to do so would violate state law, which he said was "more restrictive than federal law" ("Portland Decision," 2001, para. 2). ${ }^{243}$ The names on the Portland FBI list were not those of criminal suspects, so Kirkland deduced that some of the questions were illegal. Oregon's 1987 immigration statue and 1981 antiMcCarthyism law restrict police questioning when there is no evidence that an individual committed a crime. ${ }^{244}$

\footnotetext{
${ }^{243}$ While many states and local jurisdictions have racial profiling laws, few states have laws similar to the Oregon law, said Thomas Morrison, associate dean for the George Washington University Law School ("Portland Decision," 2001).

${ }^{244}$ ORS 181.850 and ORS 181.575.
} 
Mayor Vera Katz endorsed the police command limited cooperation decision.

Flanked by Lesh and Assistant Chief Andrew Kirkland, she issued this statement published in the Oregonian:

The city of Portland, the Police Bureau and the City Council are committed to the fight against terrorism, but within the provisions of our state law. Remember, we were sued because we violated [state] statute, so we are especially careful (Bernstein, 2001c, p. A1).

Portland police were sued twice in the mid-1990s over intelligence gathering on political activists. The city lost one of the lawsuits. The recent controversy over the role of Portland police in the FBI-led JTTF also made city officials extra attentive to state guidelines (Bernstein, 2001a\&c). One of the repeated concerns at the September City Council hearings on the Police Bureau's renewed participation in the JTTF was that Portland police would use their participation in the task force to get around the state's anti-McCarthyism statue. "This is exactly what the feds are asking the Portland Police to do," Rogers said (Bernstein, 2001a, p. A1).

Members of the local Muslim community, and civil liberties advocates, praised Portland's decision not to assist federal authorities. But more people criticized it. ${ }^{245}$ Angry mail and phone calls poured into the Portland Police Bureau and City Hall from critics across the country (Bernstein, 2001b). Local business people worried about national boycotts of Portland. Some rank-and-file street cops were embarrassed (Oliver \& Learn, 2001).

\footnotetext{
${ }^{245}$ Two-thirds of the 1,900 e-mails and letters Katz's office received on the issue were negative, many from out of state (Learn, 2001).
} 
The Portland bashing intensified after Portland Attorney Jeff Rogers supported his deputy's conclusion, despite legal opinions to the contrary. ${ }^{246}$ U.S. Attorney General Hardy Myers and Multnomah County District Attorney Michael Schrunk ruled that Oregon law did not prohibit law enforcement agencies from conducting interviews (Bernstein, 2001b). Even so, Portland stuck by its attorney's advice about not participating (Bernstein \& Larabee, 2001; Green \& Bernstein, 2001; Trevison, 2001).

For this well-publicized legal debate Portland became the "poster child" of the anti-terrorism interrogation issue, even though it was not the only city to refuse participation (Oliver \& Learn, 2001; Mitchell, 2002) ${ }^{247}$ The "City of Shame" was roasted on talk radio and chastised on the cable news networks (Bernstein, 2001b; Oliver \& Learn, 2001). The Los Angeles Times ran an editorial cartoon of Osama bin Laden heading for Portland on a goat. The local newspaper ran one depicting the city as an island (Learn, 2001). Former director of the Portland district of the U.S. Immigration and Naturalization Service, David Beebe, lambasted Portland in his editorial published in the Oregonian. He wrote:

By conveniently declaring Attorney General John Ashcroft's request for assistant 'illegal,' the left-leaning body politic of Mayor Vera Katz and City Attorney Jeff Rogers once again validates Portland's reputation as a 'little Beirut,' or, as another reader recently quipped, 'The People's Republic of Portland' (Beebe, 2001, p. B7). ${ }^{248}$

\footnotetext{
${ }^{246}$ The state legislative council agreed with Portland (Bernstein, 2001b).

${ }^{247}$ Police in Detroit, San Francisco, Seattle and Chicago dodged criticism for not participating by letting others conduct the interviews after raising concerns about racial profiling and community relations (Learn, 2001; Oliver \& Learn, 2001; Mitchell, 2002; Schabner, 2003).

${ }^{248}$ The "Little Beirut" nickname, that compared Portland to the troubled Middle Eastern city, was coined by the staff of former president George H. W. Bush after violent protests during his visits to Oregon in the early 1990s (Roe, 2002; McCall, 2003).
} 
To answer the barrage of criticism, Portland Attorney Jeff Rogers, Mayor Vera Katz, and Police Chief Mark Kroeker convened a November briefing at City Hall. They outlined, for the first time, the five questions that raised legal concerns and tried to explain why they did not accept state Attorney General Hardy Myers' legal interpretation. "Of all the jurisdictions, we probably have the most experience dealing with these statutes," Mayor Vera Katz said (Bernstein, 2001a, p. A1). “Hardy Myers didn't.” Kroeker added “The attorney general isn't going to defend us if we face litigation" (Bernstein, 2001a, p. A1).

The next day the trio held a news conference to further discuss their legal analysis. Officials emphasized that their decision to opt out of the interviews was based on a careful reading of Oregon laws. It was not the result of public opinion, political ideology, or a question of police commitment to the war on terrorism (Attig, 2001; Bernstein, 2001a).

Even though Mark Kroeker kept his promise to JTTF opponents by not breaking Oregon laws, this did not dispel Portlanders' distrust of the government (Schmidt, 2011b). The City Council still faced a room full of angry citizens at September 2002 JTFF renewal hearing. The Patriot Act was pending in Congress. Portland police were accused of using excessive force on protesters during President Bush's visit, and an exposé in the Portland Tribune on police spying had just hit the news stand (Hellegers \& Mercier, 2002) ${ }^{249}$ It is against this backdrop that the Portland City Council convened its second public hearing on the city's agreement with the FBI. Testimony at the meeting was dominated by groups opposed to the partnership, including local Muslims worried

\footnotetext{
${ }^{249}$ On September 17 the Portland Tribune ran a headline story about thousands of "red squad" style police files unearthed on Portland activists compiled during the 1970s and 1980s.
} 
about being targeted by the Portland JTTF. ${ }^{250}$ Opponents called on officials to end the city's direct participation in the FBI task force, arguing that the police-FBI partnership violated Oregon's anti-McCarthyism law. ${ }^{251}$ The Council voted unanimously in favor of renewal anyway (Hellegers \& Mercier, 2002). Mayor Vera Katz and other city officials insisted that they were compiling with state law. They cited the city's refusal to participate in the U.S. Justice Department's anti-terrorism interviews as proof. Discontent activists yelled, "Shame on you!" (Schmidt 2011a, p. A6). A few months later Chief Kroeker issued a press release announcing the creation the Muslim/Arab Police Advisory Council (Portland Police Bureau, 2000b, 2002a). ${ }^{252}$

By 2003 the players in city government had changed. Former police chief Tom Potter took office as Mayor, and according to according to Portland's Immigrant \& Refugee Task Force, there was "a noticeable shift in thinking at City Hall about immigrants and refugees" (Lensen, 2007). ${ }^{253}$ Under Potter's leadership, the City Council established a clear division between the FBI and local police with its unanimous approval of a resolution about the USA PATRIOT Act. ${ }^{254}$ The decree, adopted October 29, reiterates the Council's commitment to uphold Oregon's 1987 immigrant protection statue and 1981 anti-McCarthyism law. ${ }^{255}$ It also acknowledges the value of the city's diverse population and reaffirms Portland's long tradition of protecting the civil rights

\footnotetext{
${ }^{250}$ Other opponents included: the ACLU, Japanese American Citizens League, the League of Women's Voters, Sierra Club, Physicians for Social Responsibility and the American Federation of State, County and Municipal Employees.

${ }^{251}$ OR. REV. STAT. § 181.850 (1987); and OR. REV. STAT. § 181.575 (2001).

${ }^{252}$ The Council was established in November 2002 to advise police about the JTTF, and other concerns of 9/11-affected communities (Portland Police Bureau 2002a, 2000b).

${ }^{253}$ Potter (2004-2008) limited his individual campaign donations to 25 dollars per person because he believed that all residents should have equal access to their politicians.

${ }^{254}$ Resolution No. 36179 (2003).

${ }^{255}$ Multnomah County passed a resolution opposing the Patriot Act in December 2004 (BORDC).
} 
and liberties of all persons. The resolution expressed strong opposition to some parts of the UPA, and called on Oregon's Congressional representatives to correct provisions that impair or infringe on civil liberties. City leaders also vowed that the fight against terrorism would not be waged at the expense of "the essential right and liberties" of Portland residents.

Two years later Portland became the first city in the country to pull out of its Joint Terrorism Task Force agreement with the FBI. Led by Mayor Tom Potter, the City Council voted 4-1 to adopt a binding resolution authorizing the withdrawal of its two police officers from the federal task force in April 2005 (Griffin, 2005) ${ }^{256}$ As a former police chief, Potter made a compelling case for withdrawal, citing the potential for trespasses against civil liberties. The landmark decision ended a decade-long battle between the city council and activists over the role of Portland police in the JTTF. Commissioner Randy Leonard authored the JTTF resolution during his first term on the Portland City Council (Leonard, 2008). The action came after several public hearings on the issue and a two-year dispute with federal agents over supervision, security clearances, and the handling of the high profile Brandon Mayfield case.

Responding to public concerns about the task force targeting Muslims for their religious and political views, the city council demanded that the FBI provide the mayor and police chief with the same security clearances held by the officers on the JTTF. The FBI refused (Frank, 2005; York, 2010). Since the mayor doubles as the police commissioner, this reduced local ability to guarantee accountability. Without top-secret

\footnotetext{
${ }^{256}$ Resolution No. Substitute 36315 (2005). The resolution permits case-by-case cooperation with the FBI in counter-terrorism investigations.
} 
clearance the mayor could not provide appropriate supervision of PPB personnel assigned to the JTTF (Frank, 2010b). So the officers were removed from the task force. "[I]n this country there's an old-fashioned principle that the police or military have to be answerable to civilian oversight," Potter reasoned at one of the city council meetings (Hellegers, 2005, para. 4). He expressed opposition to blind participation in the antiterrorism task force, and concern about potential trespass on the civil liberties of the city’s Muslim community. Commissioner Randy Leonard agreed. "Here in Portland, we are not willing to give up individual liberties in order to have a perception of safety," he told the press. "It's important for cities to know how their police officers are being used" (York, 2010).

Memories of the botched FBI investigation of Brandon Mayfield also heighted local concerns about civil liberties. The case was invoked several times throughout the hearings on the JTTF. Brandon, a Portland lawyer and convert to Islam, was wrongfully arrested for the 2004 train bombing in Madrid Spain because of an erroneous fingerprint match. ${ }^{257}$ “Obviously at least one Portland citizen, Brandon Mayfield, has been terrorized by the terrorism task force that is supposed to protect us against terrorism," activist Lily Mandel said in her testimony before the Council (Hellegers, 2005, para.7). Abuse does happen, Commissioner Leonard wrote in his Op-Ed piece to the Oregonian. "And for this reason, it's vitally important to maintain a chain of command that includes the elected officials accountable to the citizens," he said. "The buck stops here" (Leonard, 2008, para. 6). Potter agreed. Before casting his vote on the Portland JTTF resolution, the

\footnotetext{
${ }^{257}$ The FBI held Mayfield even after Spanish authorities dismissed any link between him and the fingerprint. Mayfield settled with the government for \$2 million (Hellegers, 2005).
} 
Mayor emphasized that the City and Portland Police are committed to working with the FBI on a case by case basis when threats of terrorism arise. ${ }^{258}$ "We will give you what you need, but we'll do it with the supervision and control that is put into the city charter," he said (Hellegers, 2005, para. 16). ${ }^{259}$

Ten years and another mayor later, Portland weighed in on another issue involving police and civil liberties. In June 2010, the Portland City Council approved a resolution condemning the immigration law signed by Arizona Governor Jan Brewer, which critics claim encourages racial profiling. Portland's measure stopped short of the boycotts called by other cities. Instead, council members authorized city attorneys to assist with legal efforts to overturn the Arizona law. The resolution also urges city lobbyists to promote stronger Oregon laws against racial profiling (Frank, 2010a; Har, 2010).

Mayor Adams, who is openly gay, did not want to boycott Arizona travel or contracts, because it would hurt cities suing the state of Arizona over the immigration bill--Tucson and Flagstaff. "We're taking what we feel is a more productive approach," Roy Kaufman, Mayor Sam Adams' spokesman told the Oregonian, "by fighting the law" (Frank, 2010a, para. 7).

Local Latino leaders praised the Portland measure. "All this is a message," said Gale Castillo, president of the Hispanic Metropolitan Chamber. "It's a message that Portland doesn't like what it sees" (Frank, 2010a, para. 5). But a guest columnist for the

\footnotetext{
${ }^{258}$ The resolution does not prohibit cooperation with the FBI on specific counter-terrorism investigations as long as the City Council reviews agreements to ensure compliance with the protocols established in the resolution.

${ }^{259}$ All PPB personnel are accountable to the Police Chief and Commissioner-in-charge.
} 
Oregonian, who is also on the board of directors of Oregonians for Immigration Reform, saw it differently. He suggested that local residents who opposed the council's action boycott Portland by doing business in the suburbs rather than in Portland. This, he claimed, would pressure the city's "reflexively leftist council" to stop supporting illegal immigration (LaMountain, 2010, para. 9). A boycott did not happen.

\section{Worksite deportation raids}

A controversial raid at the Galaxy apartments in 1992 brought the conduct of the Immigration and Naturalization Service into question. Police and INS agents without warrants rounded up about 30 men at the complex and deported them, leaving behind some wives and children. As discussed earlier, police did not file reports, find drugs, or accuse any of the deported men of criminal charges. The apartment manager asked agents to see a warrant but was ignored. Police and agents, she said, went into apartments and dragged men out into the courtyard where they were arrested (McVea, 1992d\&e). Critics questioned whether the INS agents should have carried warrants.

Joseph Shaffer, the INS district director of investigations, said immigration agents did not need a warrant to arrest illegal aliens on public property. He also said that the apartment manager gave officials permission to enter the complex McVea, 1992e). Federal immigration law states that warrantless searches are not permitted on “commercial cartilages," or courtyards (McVea, 1992e).

Public response to the raid was fiercely critical. After news reports of the raid, Oregon's congressional delegation asked Oregon's top immigration official, David Beebe, to explain the agency's actions (Rede, 1992b). Elected officials wanted to know 
why he used limited INS resources for a non-criminal deportation raid. Congress, they wrote in their August 20 letter, specifically directed the Portland INS to combat the city's heroin problem. They also asked Beebe to respond to reports of alleged civil rights violations during the operation (Rede, 1992b). Gale Castillo and U.S. Rep. Ron Wyden also wrote to Beebe on behalf of the Portland Tar Heroin Task Force. Their letter expressed concerns about the apartment raid damaging working relationships between law enforcement agencies and the Hispanic community. They also asked Portland's district INS chief to explain how the August 4 raid conformed to the agency's enforcement priorities, and to address possible breaches in civil rights that day (McVea, 1992d\&d; Rede, 1992b). ${ }^{260}$

David Beebe refused to explain the raid to the task force. But he defended INS tactics in a letter to U.S. Sen. Mark O. Hatfield and in an interview. He told a reporter for the Oregonian that the raid did not violate INS policy, despite agency guidelines that restrict immigration searches to workplaces (McVea, 1992d). ${ }^{261}$ When questioned on the matter, Beebe said the handbook was written only as guidance. "It's not an edict," he said (McVea, 1992d, p. D21) ${ }^{262}$ In his September 26 letter to Hatfield, the INS chief said the apartments were a hotbed of criminal activity and the raid was aimed at detecting and deporting criminal aliens. He called the "area control operation" a success, even though no criminal charges were brought against any of the men deported. "Having reviewed the

\footnotetext{
${ }^{260}$ The Tar Heroin Task Force was comprised of law enforcement, business and Hispanic community representatives.

${ }^{261}$ An immigration and Naturalization Service policy handout says "raids should be limited to workplaces, except in unusual circumstances, and agents should have warrants or the consent of occupants for such searches at homes (Rede, 1992b).

${ }^{262}$ An INS spokesman in Washington, D.C. told an Oregonian reporter that the agency uses the handbook to explain federal laws to its agents (McVea 1992b).
} 
relevant facts at my disposal, I also find that our officers acted well within the scope of our statutory authority," Beebe wrote (Rede, 1992b, p. E5). ${ }^{263}$

The Portland Police Bureau did not try to defend itself, but instead the chief promised policy changes in federal raids. Other city officials stayed out of the matter until 1993. That is when members of two Hispanic advocacy organizations met with Mayor Vera Katz to seek her help in ousting the U.S. Immigration and Naturalization Service's Portland district director (Rede, 1993). ${ }^{264}$ The group was fed-up with David Beebe. He "refuses to talk to us," Luis Machorro, a member of the Hispanics in Unity board of directors, told Katz (Rede, 1993, p. C8). The group wanted the INS to work independently of the Portland Police Bureau. Federal agents were piggybacking on police raids even after police issued a limited cooperation directive; no rules prevented it (Rede, 1993; Ortiz, 1994; Bjorjus, 1997). This worried Hispanic activists. Relations between the community and police sour when "la migra" works side-by-side with police, they told Katz. Latino leaders also accused Beebe of misusing agency resources by focusing deportation efforts on people in violation of civil immigration law, instead of on convicted felons (Rede, 1993; Ortiz, 1994).

Mayor Katz was noncommittal on Beebe's removal, even though those who met with her made it clear that the simmering tensions between Oregon's Hispanic community and the INS had boiled over (Rede, 1993). Katz did agree to work with the group on five of the six issues presented in the 90 minute meeting: additional

\footnotetext{
${ }^{263}$ According to the INS special agent handbook "area control operations," such as the one conducted at the Galaxy Apartments, are to be limited to workplaces, except in unusual circumstances. Investigations at places of residence are permitted only with a properly issued search warrant or with the consent of the occupant (Rede, 1992b).

${ }^{264}$ Katz, Portland's third female mayor, served 1993 to 2005.
} 
employment and training programs, extra contracting opportunities, more

bilingual/bicultural workers at City Hall, a greater voice in the development of law enforcement policies and expanded bilingual education in the schools (Rede, 1993).

Unable to get local government to take action against Portland's INS chief, workers rights' groups took their grievances to the people. When a surge in worksite raids across the state created "a reign of terror" in the late 1990s, a coalition formed to stop the sweeps (Blackmun, 1997; Pulaski, 1997). Worksite arrest and deportation rates soared after agents were added to the Portland INS office. ${ }^{265}$ The district's detention and deportation staff grew from 10 to 35 in two years, and its investigation and apprehension staff, from 20 to 25 (Taylor, 1995; Blackmun, 1997; Pulaski, 1997). Escalated district efforts, Beebe said, were the result of a congressional mandate powered by a boost in funding from national headquarters. ${ }^{266}$ Immigration officials announced plans to double deportations of immigrants working illegally in Oregon. That worried community activists who say that the INS has trampled the civil and human rights of those arrested in raids (Blackmun, 1997; Portland Copwatch, 1998b). Many of the deportation arrests were caught on film by the Workers Organizing Committee Migra Watch program (Hortsch, 1998). ${ }^{267}$ According to Copwatch, Portland INS Enforcement Chief Joe Shaffer was one of the officers catch abusing workers (Portland Copwatch, 1998b). About 100 people

\footnotetext{
265 "From October 1995 to September 1996 officials for the Portland district (which covers all of Oregon) arrested 2,045 illegal immigrants after workplace and criminal investigations, said Phillip C. Crawford, deputy district director. INS expects to deport 3,200 this year, he said. Since October 1996, he said officials have surpassed the workplace arrests and expect the number to rise well past 800 - doubling the number arrested last year-by September" (Blackmun, 1997, p. C1).

${ }^{266}$ In 1996 Congress passed laws that increased the agency's budget and enforcement authority.

${ }^{267}$ The WOC began working with day laborers in 1994 to identify problems and generate solutions (Rede, 1993). Migra Watch was formed as a team from the community who stand on the corner with cameras (Wallace, 2001).
} 
picketed the agency's Portland district office in May 1997 in response. The protest was organized by Causa ' $98 .{ }^{268}$ The group released a statement complaining about immigration policies and mistreatment (Blackmun, 1997).

After laying low during months of public criticism and protest, the INS resumed its raids in February and March of 1998. The raids were prompted by business owners' complaints about day laborers congregating on street corners. The Workers Organizing Committee (WOC) and its allies held a press conference and rally at the site of the March 25 raid - the Plaid Pantry parking lot, to publicize what was happening on the "job corners" in Portland. Teresa Enrico, director of the WOC, and others spoke out about INS sting operations and thuggish arrest practices during arrests. She said INS agents wearing civilian clothes, and driving unmarked vehicles, lured workers into a van under the pretense of employment. Workers, she charged, were punched, chased down, held in choke holds and handcuffed; some were legally in the United States. Religious leaders and others condemned the INS violence or talked about the laborers right to work (Pulaski, 1997; Hortsch, 1998; Jacklet, 2000). ${ }^{269}$ Portland Copwatch accused the INS of racial profiling in its April 1998 issue of Peoples Police Report, which read:

In Portland, the INS has almost exclusively targeted dark-skinned, Spanishspeaking people, even though there are large numbers of undocumented 'aliens' from Asia and Europe. Clearly, the selective enforcement of immigration laws belies the fact that the law isn't what's being served here (Portland Copwatch, 1998a, para. 6).

\footnotetext{
${ }^{268}$ Causa '98 is coalition of various Hispanic, labor and other groups.

${ }^{269}$ Speakers included: Rev. Lynn Lopez, pastor of Ainsworth United Church of Christ; Raul Velazques, director of Hispanic Ministries of the Roman Catholic Archdiocese of Portland; and Joseph Tam, a member of the Portland Rainbow Coalition (Hortsch, 1998).
} 
Joe Shaffer, assistant director of the Portland district for the INS, confirmed the raids, but disagreed on the nature of the tactics (Hortsch, 1998). He also denied allegations from raid witnesses who claimed agents did not identify themselves as INS officials when they gave chase to suspected "illegal" immigrants (Snell \& Anderson, 1997). Shaffer said that wasn't what happened. A number of private citizens left their own cars when the raid began to track down people who ran away from INS agents, he told reporters. Shaffer swore agents wore jackets identifying themselves (Snell \& Anderson, 1997).

The Workers Organizing Committee, in cooperation with local religious and labor organizations, held a series of vigils and marches to protest INS undercover sting operations (Portland Copwatch, 1998c). The group initiated a letter writing campaign to try to force the INS to respect workers' rights. They asked their allies to send letters to the INS. The letters ask agents to stop the raids and join the ongoing community dialogue between day laborers, the WOC, and neighborhood residents and businesses. This led to a 1998 negotiation between day laborers, their advocates and the director of Portland's INS (Portland Copwatch, 1998c).

Beebe agreed to meet with a coalition to discuss the issue. The coalition-comprised of representatives from CAUSA '98, Oregon Council for Hispanic Advancement, American Friends of Service Committee, Jobs with Justice, Hispanic Ministries (part of the Catholic Church), the Hispanic Chamber of Commerce and WOC — met with Beebe and other INS agents on June 18 (Portland Copwatch, 1998a). 
When the INS crew arrived, they were greeted by a group of about 150 immigrant and workers' rights supporters standing vigil near the doorway. Inside, coalition leaders presented a list of demands:

They demanded that District Director Beebe maintain communication with the coalition. They also demanded that the INS refrain from propagating false and derogatory myths and stereotypes about immigrants to the public, as they have often done to justify their attacks (Portland Copwatch, 1998c, para. 6).

Afterwards, Beebe told the still standing crowd outside that he would expect all his agents to behave in a "professional manner." He also promised to continue meeting with the community on a regular basis (Portland Copwatch, 1998c, para. 8). The meeting got the INS to back off. Raiding on the corner stopped (Jacklet, 2000; Wallace, 2001).

A few years later, the conduct of Portland INS agents ignited another firestorm. In August of 2000, Mayor Vera Katz joined Mike Thorne, the executive director of the Port of Portland, Oregon Governor John Kitzhaber and Northwest members of Congress, in calling for David Beebe's resignation (Flecther, 2000; Read \& Sullivan, 2000c). ${ }^{270}$ A four-month investigation by the Oregonian found an agency culture imbued with racism and riddled by questionable conduct (Christensen, 2000; Christensen, Read, Sullivan \& Walth, 2000; Read, 2000). Complaints were piling up about the abusive treatment of immigrants and foreigner travelers by Portland immigration agents. INS officials at the Portland International Airport were refusing foreign-travelers entry into the country at rates far higher than their counterparts at other West Coast airports (Fletcher, 2000).

${ }^{270}$ On Aug. 30, 2000, two senators called on INS Commissioner Doris M. Meissner to remove the head of her agency's Portland office (Fletcher, 2000). 
The final straw was when inspectors strip-searched and jailed a Chinese businesswoman with a frayed passport, who was later declared innocent (Fletcher, 2000). ${ }^{271}$ They also deported the German wife of a U.S. citizen back to Europe without her breast-feeding baby. Mayor Vera Katz, described the incident as "monstrous" (Verhovek, 2000; Thomas, 2001).

Portland officials blasted Beebe for damaging Portland's international reputation. The highly publicized incidents generated negative press in foreign countries, and earned the city the nickname "Deportland" (Fletcher, 2000; Burghart \& McCall, 2000; Christensen, Read, Sullivan \& Walth, 2000; Read \& Sullivan, 2000b\&c). ${ }^{272}$ The problem had gotten so bad, airport officials told a reporter for the Washington Post that some Asian travel agents were advising their clients against entering the United States through Portland (Fletcher, 2000). "For them to fall back on their old Gestapo-type actions is just unacceptable," Thorne told Asian Week. "Enough is enough" (Burghart \& McCall, 2000, para. 20). Community members demanded an overhaul of the Portland INS office.

In an August 23 letter to Attorney General Janet Reno, Katz and others accused INS inspectors of treating foreigners unfairly at local jails and the Portland airport. They demanded a top-down federal investigation of Beebe's Portland-based operation (Burghart \& McCall, 2000; Christensen, 2000; Christensen, Read, Sullivan \& Walth, 2000; Read \& Sullivan, 2000a; Verhovek, 2000). David Beebe retired under pressure

\footnotetext{
${ }^{271}$ She was released after spending two nights in jail when forensics experts determined her passport was not fraudulent (Fletcher, 2000).

${ }^{272}$ That is what airport officials and others called the INS mistreatment of foreign travelers — particularly Asians-in Portland.
} 
after an INS task force report went public. The report found that the Portland district office suffered from rigid, heavy-handed enforcement of laws and lack of communication between the INS and the citizens it services (Read \& Sullivan, 2000c).

The debate over INS tactics did not end when Beebe left the agency. In 2007, Mayor Tom Potter blasted ICE after federal agents raided the Fresh Del Monte fruit packing plant in North Portland. The June 12, 2007 immigration raid was the largest in recent Oregon history (Denson \& Hunsberger, 2007). One hundred sixty federal agents swooped into the packing plant and arrested 169 line workers accused of immigration law violation. Agents also arrested three staffing managers at American Staffing Resources for their role in helping employ the alleged undocumented workers (Denson \& Hunsberger, 2007; McCall, 2007). ${ }^{273}$

The arrests sparked criticism from immigration reform supporters, workers rights advocates and Tom Potter. Immigrant rights supporters held a protest at the federal building in downtown Portland the day of the raid, and later at the detention center. Potter issued a same-day written statement expressing anger that "Portland residents" were swept up in the arrests, and blaming Bush and Congress (Denson \& Hunsberger, 2007) . The statement read:

I certainly understand why federal officials executed criminal warrants against the three individuals who stole and sold Social Security numbers. But to go after local workers who are here to support their families while filling the demands of local businesses for their labor is bad policy. It also serves as a reminder of the failure of our national leaders to deliver an immigration policy that is both fair and humane and acknowledges the economic realities of our country.

\footnotetext{
273 "The action was part of a six-month criminal investigation into the North-Carolina-based employment agency, which U.S. Immigration and Customs Enforcement accuses of conspiring with Fresh Del Monte to hire and employ undocumented workers" (Denton \& Hunsberger, 2007).
} 
Our nation would be better served if this kind of energy was focused on creating a comprehensive approach to immigration reform that provides a path to citizenship; addresses the immigration backlog that keeps families apart; and provides a safe and legal way for workers to enter our country and be productive workers and taxpayers. Immigrants provide more than mere labor in our community. They have long enriched our history, our culture and our city. My heart goes out to families dealing with the aftermath of this morning (Portland Office of the Mayor, 2007).

Potter's office received about 800 emails and phone calls after his statement on the raid was released (Anderson, 2007). "It's the most e-mails we're ever gotten on a single subject," Potter's spokesman, John Doussard, told the Portland Tribune (Anderson, 2007a). Many came from people outside Oregon, who did not understand why a former police officer and ex-police chief would condemn instead of support the raid. Doussard thought most of these calls were fueled by national talk radio (Anderson, 2007a). Other calls came from Oregonians who thought Mayor Tom Potter violated the oath of his office by not supporting the laws of the land (Anderson, 2007a).

Local newspapers and blogs were also inundated by citizens expressing both opposition and approval for Potter's response. "The chairman of the People's Republic of Portland is again in a snit over rounding up illegal immigrants," one reader of the Oregonian wrote in a letter to the editor. "What is it that Potter does not understand about the English word illegal?" (Furrer, 2007, p. D11).

Even with the criticism, a day later, Potter implied the raid was a political ploy. He suggested the federal government used warrants against the three managers as an excuse to conduct deportation sweeps during a tense debate in Washington, D.C. over a 
change to the nation's immigration laws (Griffin, 2007b). ${ }^{274}$ "How many people did they arrest?" he said. "They certainly didn't have many warrants...It's just very

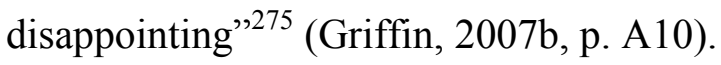

The Mayor made it clear that no Portland police officers participated in raid, although a few did provide traffic control. And the Bureau's Crisis Response Team was activated to help the families of the workers detained (McCall, 2007). ICE wouldn't have gotten more help even if they'd asked. "We don't do that kind of thing," Potter told reporters (Griffin, 2007b, p. A10).

What the city of Portland did do was donate $\$ 20,000$ to help people caught in the raid pay rent. Immigration and Customs Enforcement prohibited those arrested from working while they awaited deportation. The donation was made through the Bureau of Housing and Community Development. According to the Oregonian, the money came from a fund for a housing project that never materialized (Bermudez, 2007c). Catholic Charities distributed the funds. Commissioner Erik Sten, whose office oversaw the donation, notified Mayor Potter about the possibility of whole families ending up in the street if the city did not provide shelter. The contract with Catholic Charities was approved without public input or City Council approval, although officials did hold a meeting with concerned community groups (Bermudez, 2007c). According to the

\footnotetext{
${ }^{274}$ The arrests came the same day that President Bush paid a rare visit to Capitol Hill to try to revive support for immigration overhaul legislation that faltered in Congress week.

${ }^{275}$ Worksite raids increased after the ICE agency was formed in 2003, which was a significant departure from the practice of targeting "illegal" immigrants who have committed other crimes (Read, 2007).
} 
Oregonian, city officials anticipated that their support might provoke some criticism, but they believed it was necessary to prevent homelessness. "It just doesn't make sense to not have children sheltered," Sten explained (Bermudez, 2007c, p. C4).

Jim Ludwick, president of Oregonians for Immigration Reform (OFIR), questioned the city's donation. ${ }^{276}$ "Where are the priorities of a government that spends money on people who are in the country illegally instead of spending it on American citizens?" (Bermudez, 2007c, p. C4). Ludwick argued that if city officials rush to prevent homelessness among displaced illegal immigrants, they should also aid the families of jailed bank robbers and drug users (Bermudez, 2007c).

The grant helped twenty three families. Besides helping pay their rent, the city asked Catholic Charities to increase the families' knowledge of immigrant and renters' rights users (Bermudez, 2007c). At the same time, members of Oregon's New Sanctuary Movement moved to support those arrested (Bermudez, 2007b; Haught, 2007b). ${ }^{277}$ Ludwick told the Portland Tribune that he wasn't surprised by the group's efforts. He called Portland a "sanctuary city," claiming support from Mayor Tom Potter and other city commissioners for a day labor center in Northeast Portland proved it. The site, Ludwick complained, made it easier for illegal immigrants to get paid jobs (Law, 2008).

\footnotetext{
${ }^{276}$ OFIR, which was organized in 2000 , claims its membership has grown from about "100 originally to well over 2,000" by 2010 (Har, 2006; OFIR, 2010). However, President Jim Ludwick stepped down in December 2010 and nothing much has been published on the website since.

${ }^{277}$ Today, the Oregon New Sanctuary Movement (ONS) is an interfaith coalition of over 20 different Oregon faith communities - Christians, Jews, and Muslims--called to respond actively and publicly to the suffering of immigrants residing in the United States (Oregon New Sanctuary Movement , 2011).
} 


\section{Unregulated day labor-contractor market exchanges}

Day labor was another point of contention in Portland. Day laborers, many of them second generation farmworkers, began showing up in Portland in 1992. Then, as many as 75 mostly Latino men gathered at several pick up corners or in parking lots outside nearby stores, weekday mornings waiting to be hired as day laborers (Tongue, 1997; Gonzalez, 1998; Jacklet, 2000; Bermudez, 2006). As the numbers grew to 150-200 in the late 1990s, so did the complaints (Bermudez, 2006).

Business owners grumbled about workers urinating and defecating on sidewalks, leaving garbage behind, and scaring off customers (Snell \& Anderson, 1997). They called the mayor and police chief. But local officials did nothing to rid the neighborhood of day laborers (Jacklet, 2000). Other business owners were bothered more by the employers who picked up the workers (and did not pay for health care benefits or taxes) than by the workers themselves (Tongue, 1997).

Business owners were not the only group concerned. Laborers and their advocates started to chime in too. They complained that day laborers were being taken advantage of: employers were not paying workers for a day's work, or refusing to pay medical bills when an employee got hurt. Workers also objected to the racial epithets shouted at them from passing cars (Griffin, 2008). Police working in the area were aware of these problems and concerned. "We actually had a problem with people who were robbing the people seeking jobs there," Lt. John Drum of the Portland Police Bureau's Southeast 
Precinct reported (Tongue, 1997, p. D1). Drug dealers using the steady morning traffic of trucks and sports utility vehicles as a cover for their trade, also troubled police (Tongue, 1997).

Several community groups tried to come up with a permanent solution. In 1996, a group of police officers, area business owners and community groups gathered to discuss the issue. Ed Blackburn, the director of an area alcohol and drug detoxification program, spearheaded the discussions. "We agreed that there was a problem," Blackburn said in a press interview. "But it was a labor problem, we decided, not a law enforcement problem" (Tongue, 1997, p. D1). The group's discussions lead to the conclusion that the workers needed a safer place to market their labor and a community organization needed to create such a place.

The Workers Organizing Committee agreed to try, but ran into difficulties: the instability of the day labor community (WOC contacts were picked up and deported in raids, or scared away), and trouble funding a center for workers who do not all have legal papers. Peter Finley Fry, a land-use planner for the Central Eastside Industrial Council, faced similar obstacles when he tried to create a center for day laborers (Tongue, 1997). The Council, a private, nonprofit business association dedicated to the revitalization of Portland's central eastside, had asked Fry to move the day laborers off the street corner and into an indoor center. The crowd of men hanging out on the street was scaring away potential shoppers and apartment renters (Tongue, 1997). When discussions produced no 
concrete solutions, business owners called the INS to complain. Federal agents responded with deportation sweeps on "job corners."278

To open a day labor center, community organizers needed city support. In 1998, Serena Cruz, an aid to Commissioner Erik Sten, tried to find a solution to the day labor dilemma. To support her effort, the city and state paid for $\$ 20,000$ worth of community mediation sessions (Jacklet, 2000; Decker \& Associates, Inc., 2004). The funding came after Migra Watch volunteers held a press conference to publicize INS human rights violations (Hortsch, 1998). But the dispute resolution failed to break the stalemate between contending factions. Business leaders, who were determined to move the laborers along, refused to support a hiring hall in their neighborhood (Jacklet, 2000). Workers' rights advocates objected to establishing a center elsewhere, arguing that doing so would jeopardize job opportunities for day laborers. The "job corner" is a known location by workers and employers, they explained. It is strategically located close to major highways and high traffic streets (Wallace, 2001).

"I haven't been able to understand why we can't talk about this and figure it out," Cruz (later a county commissioner) said in a Willamette Week interview afterwards (Jacklet, 2000, para. 4). The reporter interviewing her came to this conclusion on the matter: "Part of the problem is bad blood. For years, the Worker's Organizing Committee fought aggressively for the rights of the day laborers" (Jacklet, 2000, para. 4).

\footnotetext{
${ }^{278}$ In Portland, the "job corner" actually includes several corners at the intersections of East Burnside Street and Grand Avenue and Martin Luther King Jr. Boulevard.
} 
Confrontations between day laborers, advocates and the INS continued until the raids ended in 1998. Afterwards, control of the day labor problem shifted to the Portland Police Bureau. Police started running workers and their potential employers off the street corners. ${ }^{279}$ Day laborers and their advocates complained. Eventually a new process of negotiations began (Portland ON1, 2003b).

In January 1999, police and the workers' committee drafted a non-harassment contract. The agreement outlined standards of conduct for day laborers and police, while also addressing the concerns of area business owners and residents. ${ }^{280}$ But Chief Charles Moose refused to sign it (Bernstein, 1999; Wallace, 2001).

After a couple of run-ins with police, discussions between day laborers and the PPB broke down. In March, the Day Laborers Committee of Portland sent a letter to Chief Charles Moose demanding action (Bernstein, 1999). The letter, written on Workers Organizing Committee stationery, was signed by 53 people. In it, the group alleged two specific incidents of police harassment. ${ }^{281}$ "What we are asking is that if nothing unusual is happening, that the officers do not stop to intimidate us," they wrote (Bernstein, 1999, p. D2). Day laborers claimed they were not engaged in criminal activity or creating disturbances while waiting for work (Bernstein, 1999). The letter was also sent to Mayor Vera Katz and several Latino associations.

\footnotetext{
${ }^{279}$ Mainly along Southeast Sixth Avenue and East Burnside.

${ }^{280}$ For example, workers would not gather in front of homes or block driveways or businesses and would be off the street by noon each day. In turn, the police would increase their presence in particular areas of concern to discourage illegal activities and would appoint a police officer to serve as a liaison between the day laborers and the bureau (Bernstein, 1999).

${ }^{281}$ March 6, 1999, day laborers claim a police officer told a worker to move off Sixth Avenue or federal immigration agents would show up. The day before, they say a potential employer was stopped by police and told he would be arrested if he was seen picking up workers from street corners (Bernstein, 1999).
} 
Assistant Chief Lynnae Berg, speaking on behalf of Moose, said the chief was offended by the workers' ultimatum. The bureau wants to reach an agreement that would protect the laborers' rights to look for work while also guaranteeing public safety, she told reporters. But Moose will not sign any agreement with an organizing group, only with individual laborers (Bernstein, 1999). The idea did not seem feasible to workers.

Overtime, disagreements within WOC caused the group to spilt-up. A splinter group, VOZ (Voice) Workers' Rights Educational Project emerged. ${ }^{282}$ They sought to win over the same business community that WOC alienated (Jacklet, 2000). In 2003, the city of Portland awarded City Repair and VOZ a $\$ 5,000$ grant. ${ }^{283}$ The funding came from the Project Interwoven Tapestry, which was part of the Building the New American Community Project (Portland ONI, 2003a). ${ }^{284}$ The group built a "Plaza Latina" in the neighborhood where day laborers congregated to look for work. ${ }^{285}$ They also created events to bring together residents, SE neighborhood businesses, and day laborers who often wait there for work (Portland ONI, 2003a).

Meanwhile, the relationship between business leaders and workers' rights advocates grew more strained. The two groups had regularly attended Monthly Community Policing Action Committee meetings in an effort to foster positive relationships (Davis \& Ruiz, 2007). But as the number of day laborers in the area increased so did the complaints. "The business people have been angry with day laborers,

${ }^{282} \mathrm{VOZ}$ was established in 2000 to secure and protect immigrant workers' rights through education, leadership development and community organizing.

${ }^{283}$ The grant came through the Southeast Uplift Neighborhood Coalition (SEUL) because neither group had nonprofit status.

${ }^{284}$ The Building the New American Community Project was an effort to foster successful refugee and mainstream community integration by developing leaders, coalition building, and encouraging participation in the political process.

${ }^{285}$ Plaza Latina is located at SE 8th and Ankeny. 
saying it's time to move on from the corner. And now they're trying to use police to get rid of day laborers," VOZ director Romeno Sosa told the Portland Mercury (Davis \& Ruiz, 2007, para.7). The two sides disagreed on the laborers' right to wait for work on the sidewalk. Business owners, wary of waiting for a hiring center to open, wanted police to move the workers somewhere else since they do not have a permit to congregate on the sidewalk. Sosa said there was no law prohibiting it. City Attorney Woboril weighed in: "There is no law against a number of people congregating on a sidewalk as long as they don’t block traffic.” (Davis \& Ruiz, 2007, para. 14).

When the issue of an anti-solicitation ordinance came up again, Kevin Easton, Potter's business and arts policy manager and point-person on the day labor issue, said city officials do not foresee adopting one. Easton was quoted in the Portland Tribune saying:

[It's seen as a] police answer to a more complicated question. The mayor believes you can't police your way out of the situation. There's too many economic forces that pull it back and don't address need of the community, as well as (concerns of) business and traffic congestion (Anderson, 2007c, para. 32).

As pressure mounted to relocate the day laborers, Mayor Tom Potter took a greater role in the creation of the day labor center, which he first talked about during his 2004 campaign (Griffin, 2008). At his urging, the City Council gave VOZ another $\$ 5,000$ on March 8, 2006. The grant, part of the Community Grants Program, was one of the components of the overall Engagement Plan for the visionPDX project. ${ }^{286} \mathrm{VOZ}$ used the funds to identify a new vision for the ways in which day laborers wait for work in urban Portland. Focus groups, questionnaires, and a cultural event to were used to reach out to

${ }^{286}$ VisionPDX, launched in 2005 by Mayor Tom Potter, was an extensive public engagement process to develop a shared vision for the Portland community for the next 20 years and beyond (VisionPDX, 2013). 
400 people--day laborers, local officials, businesses and nonprofits at the corners where day laborers find work, as well as members of VOZ and partners of day laborers (VisonPDX, 2007).

That same year $\$ 200,000$ was set aside in the city’s 2006-2007 budget for a day labor center (Maushard, 2007; Pein, 2008a). ${ }^{287}$ Still, it took a while for the day labor relocation project to get off the ground. Securing a good location took nearly a year. The advisory committee appointed by Mayor's Potter's office had to decide where to locate the center. Seven sites were proposed, all on the inner east side. Then Potter's staff had to negotiate with landowners (Anderson, 2008a). In the meantime, the city hired a project leader to get things moving--run meetings, collect input from all sides, and help determine day labor center programming and logistics. ${ }^{288}$ Local officials also convened a series of hearings at City Hall to solicit public comment on the proposed site- a vacant city-owned lot near the day laborers existing pick-up area in the eastside business district (Maushard, 2007). “As far as the legality of immigration, that's a national problem," Bob Wentworth, a member of the First Steps Committee said. "We're dealing with a local problem - a large group of men gathering on a corner.” (Anderson, 2007d, para. 13). Wentworth was a Central Eastside Industrial District (CEIC) board member and leading figure calling for the relocation of the day laborers. The committee formed by Potter's

\footnotetext{
${ }^{287}$ City officials first tried to lump the center in with initiatives for the homeless--the mayor's Street Access for Everyone (SAFE) public safety initiative, until advocates convinced city officials that the two groups' needs were different (Davis \& Ruiz, 2007;Anderson, 2008e; Eyck, 2008).

${ }^{288}$ A portion $(\$ 20,000)$ of the $\$ 200,000$ day labor center financing went to the hire the project director.
} 
staff held meetings above the Wentworth Chevrolet showroom. The committee had several big issues to address: where to locate the center and who should foot the bill (Griffin, 2007a; Maushard, 2007).

"It's amazing that we have somebody elected, in office, who forms a committee to talk about how to evade the law," Jim Ludwick, president of Oregonians for Immigration Reform, said in an Oregonian interview (Griffin, 2007b, p. C1). "Even if this thing were privately funded, you're basically aiding and abetting illegal activity loudly as possible" (Griffin, 2007b, p. C1). After learning about the funding for the center, the conservative watchdog group Judicial Watch faxed a warning letter to Potter. According to the Portland Tribune, the letter advised the mayor of the group's "serious legal concerns" about using taxpayer money to fund a center for illegal day laborers, which they contend violates federal law (Anderson, 2007d, para. 7). In an earlier press interview, Chris Farrell, director of research for Judicial Watch, accused the city of Portland of "subsiding criminal activity," and threatened to sue (Anderson, 2007c, para. 7).

Despite the threat of legal action, Potter and his committee continued to work on the project. The mayor has been criticized constantly for supporting day laborers, Kevin Easton told the Portland Tribune, adding:

But it doesn't affect the mayor's opinion on this, one way or another. They're residents of this city. The most vulnerable residents of the city deserve things as well. The community this impacts deserves it all well. It's not just an investment in the job-seekers on the site. It's an investment in the community and in Portland (Anderson, 2007b, para. 4). 
In 2008, at Potter's urging, the Portland City Council unanimously approved the day labor center project and appropriated the money for it. ${ }^{289}$ The Mayor, like several of the other commissioners, said the ordinance was about "basic human dignity" (VOZ, 2008). The council took testimony at City Hall beforehand. More than 30 people testified on the grant, most of them in support. The critics argued that the center would attract more illegal immigrants. Some nearby business owners complained about not getting adequate notice of the proposed site. The conservative watchdog group, Judicial Watch, threatened the mayor's office with a lawsuit again (Green, 2008; Pein, 2008b).

The $\$ 200,000$ grant provided operating funds for the nonprofit VOZ Workers Rights Education Project--the group awarded the contract to manage the day labor site. ${ }^{290}$ VOZ was the only group that responded to the city's request-for-proposals (Anderson, 2007d). A staffer in Mayor Tom Potter's office, Kevin Easton, was selected to oversee the day labor development project (Green, 2008; Griffin, 2008b; Mayer, 2008). ${ }^{291}$ Day laborers would decide how the center should be run (Anderson, 2007d).

Project director, Romeo Sosa, planned to open the center on May 6. But land use issues put site preparations behind schedule. According to the Willamette Week, an April 30 memo from the Bureau of Development Services stated that plans for the center were "unable to meet zoning-related standards" (Pein, 2008b, para. 4). ${ }^{292}$ The City Council voted to waive building requirements for the planned center. The council also waived a city design-review process that usually takes two or three months, and rarely favors

\footnotetext{
${ }^{289}$ The money was "rolled over" from the 2006-2007 budget cycle.

${ }^{290}$ City Council members expect the center to support itself after the first two years (Griffin, 2008b).

${ }^{291}$ Carmen Rubio took over the project after Potter staffer Kevin Easton left the city to join a nonprofit.

${ }^{292}$ Those standards require building walls at least 15 feet high, with windows and a door facing the street, pedestrian walkways and a storm water filtration system (Pein, 2008b).
} 
trailers. The purchase of a tent and a trailer was also delayed; the first check from the city arrived late (Pein, 2008b). Commissioner Randy Leonard, who oversaw the Bureau of Development Services, sponsored the April 30 ordinance. To get the hire site open on time, the Bureau waived hundreds of dollars in permit fees for VOZ, noted the Willamette Week (Pein, 2008b). VOZ pays the Portland Development Commission $\$ 1$ a year to lease the property. ${ }^{293}$ The previous tenant, Wentworth Chevrolet, paid $\$ 300$ a month (Pein, 2008b).

The city held meetings in January and March of 2008 to try to get neighbors to hammer out a good-neighborhood-agreement before the center's revised June opening date. The "effective engagement solutions" coordinator for the Office of Neighborhood Involvement told the Portland Tribune that she was disappointed with the low turnout. Mediators spent the next three weeks knocking on doors and posting flyers to try to get neighbors engaged in the process (Anderson, 2008a). The Central Eastside Industrial Council and other stakeholders in within a two block radius of the new center, signed off on a good-neighborhood-agreement before it opened (Anderson, 2008d). The nonbinding agreement states that VOZ will use outreach and education efforts to address concerns that may arise, like crime and nuisance in the area or day laborers who solicit work offsite (Anderson, 2008d).

After years of negotiations with the city and local businesses, on June 13, 2008 VOZ held a ceremony commemorating the opening of the new day labor center. Latino activists, workers and Portland City Council members, including Mayor Tom Potter, were present for the ribbon cutting ceremony (Sosa, 2008). During the party Potter made

\footnotetext{
${ }^{293}$ The property is on the corner of Martin Luther King Jr. Blvd. and Northeast Everett Street.
} 
this statement: "[The day labor center] represents the values of Portland. We believe people who want to work should be allowed to do that" (Griffin, 2008b, para. 6).

Mayor Potter told the Oregonian that the idea behind the center is to provide a safe, warm place where the often-exploited, low-wage workers can connect with employers in a humane, dignified atmosphere. He explained his rational this way:

All you have to do is drive down MLK early in the morning and look at people out in the cold, in the rain, in the snow, looking for work. They are not committing crimes. They are looking for work. That's a basic right of anyone in our community (Mayer, 2008, p. B1).

A few days later (on June 16) Portland's makeshift day labor center officially opened (Griffin, 2008c). It consists of a parking lot and a mobile trailer (containing offices for a site director and a dispatcher), two port-a-potties, a 30-foot tent (to shelter workers), and bike racks. The center has a site manager and an organized job distribution system. It is open Monday through Saturday from 6 a.m. to noon. There are strict rules against drinking, drug use and drug dealing. Workers sign up when they arrive. Their names are entered into a raffle to determine the order for available work. Contractors must agree to pay at least $\$ 10$ an hour. The aim is two-fold: offer laborers a safe place to wait for work and clear people for looking for work off the sidewalks in front of businesses. People who come to the site are not required to show identification or proof of citizenship in order to work (Heye, 2008; "Day Labor Site Open," 2008). This policy does not sit well with everyone.

On opening day, one man sat in protest in the driveway leading to the citysubsidized site. He held up a sign that simply said "no." Officers gave the man a warning for blocking the entrance to the new day labor center. He left but returned the next day to 
wait for police to arrest him, and that is what happened. Police charged Tom Wenning with criminal trespassing (Anderson, 2008c; "Lone Protestor Arrested," 2008). According to $K A T U-T V$, a judge convicted Wenning of disorderly conduct and ordered him to pay a $\$ 500$ fine in August. He filed a civil lawsuit against Mayor Tom Potter and three other council members for using public funds to support illegal activity ("Day Labor Center Protestor,” 2008).

Oregonians for Immigration Reform, and members of the Oregon chapter of the national Minuteman Civil Defense Corps, picketed near the old informal day labor site in October $2006 .{ }^{294}$ The sign-toting, flag waiving protestors carried video cameras and recorded license plates of vehicles that stopped. The four-hour protest was marked by occasional shouting matches but no violence (Green, 2006; Maushard, 2007). The group vowed to continue confronting people who try to hire day laborers at the Burnside "job corner." But neither group showed up to protest the new taxpayer-funded workers' center. The center did draw opposition in the blogosphere, including calls for police action and immigration raids (Anderson, 2008f).

On the day the center opened for business, Mayor Potter tried to set critics straight. "Street corner hiring is not a police issue, it's a community issue," Potter said in press release. "A day laborer hire site represents a practical, safe solution to keeping our neighborhoods livable and our businesses strong" (Anderson, 2008b, para. 18). A reporter for the Portland Tribune summed up Tom Potter's position this way: The day labor initiative addresses a livability issue. The illegal immigration debate is a matter for Congress to sort out (Anderson 2008b).

\footnotetext{
${ }^{294}$ The informal solicitation site was on the corner of Southeast Sixth Avenue and Burnside Street.
} 
Despite the controversy, two months later (August 2008), the Portland City Council awarded VOZ a $\$ 10,000$ "Vision into Action" grant to help the group fight the anti-immigration backlash. The funding for the grant came from the city's Bureau of Planning for an initiative called "Building Bridges" (Anderson, 2008f) ${ }^{295}$ VOZ used the grant to conduct outreach to the community through neighborhood cleanups and cultural events (Anderson, 2008f). VOZ leaders hoped the initiative would also help with the street corner dilemma.

About a month after the new day labor center opened, some workers gravitated back to their old street corners, just blocks away. VOZ operators complained about getting far more job seekers than employers at the center (Heye, 2008). Since there was not enough work for everyone waiting, some day laborers tried to improve their chances by returning to unregulated roadside job hunting.

Before the new center opened employers expressed skepticism about the idea working. Some thought city involvement might cause them to pay laborers higher wages. Others feared anti-immigrant groups or federal investigators might target the job center and anyone seen pulling up there (Griffin, 2007c). When asked for his view on the matter, Southeast Precinct Lt. Bob Heimbach told the Portland Tribune that employers might be staying away from the hire site out of desire to remain anonymous (Anderson, 2008d). At the center, employers are asked to give their name and contact information, but it is not mandatory. Employers must also agree to pay workers a minimum of $\$ 10$ per hour, instead of setting their own rate.

\footnotetext{
${ }^{295}$ The grants supported some of the goals developed during the Community Vision Project that Potter championed during his first term in office.
} 
Critics claimed the center was not working because it failed to keep workers off their old street corners and failed to attract enough employers to the hire site. Members of the good-neighbor group pressured $\mathrm{VOZ}$ to rein in day laborers who were soliciting work off-site (Anderson, 2008d). VOZ leaders agreed to try to promote the site better, but said they could not force workers to come there. Police Lt. Heimbach told the Portland Tribune that there are no laws restricting roadside job hunting--the city's sit-lie ordinance only applies to downtown, and there is no loitering statue on the books. And going after people solely for their immigration status, he noted, is against Oregon law (Anderson, 2008d). The PPB relies on community policing instead. Officers regularly drive by the work site to chat with the workers on the street corners (Anderson, 2008d). According to Carmen Rubio, Mayor Potter's community affairs director, Southeast Precinct Commander Derrick Foxworth instructs officers to refer laborers to the new hire site. But still, Heimbach noted, "You can’t force people to go places. We are very limited at what we can do from a law-enforcement perspective" (Anderson, 2008d, para. 26).

To solve the problem, VOZ asked the National Day Labor Organizing Network for help. The group got contractors to agree to consistent wages and basic labor laws (Eyck, 2008). In 2009, the VOZ center also switched from a lottery system to a firstcome, first-serve job distribution method. More employers started to use the site, as did workers (McFadden, 2009).

As Mayor Tom Potter's term of office came to an end, some worried that Portland's day labor center might not survive after his tenure. Without a vocal proimmigrant figure like Potter, there was no guarantee that Portland's next council will be 
as supportive of the site (Pein, 2008a). Commissioner Sam Adams, the front-runner in the race to replace Potter, was absent when the council voted in favor of the site in March. He said in a radio interview, that he was sick but would have voted aye (Pein, 2008a). ${ }^{296}$ Adams was Potter's successor.

The center is still going, even though the Portland City Council did not any give money to the labor site after its first $\$ 200,000$ investment (Griffin, 2008c). VOZ did not request any funding; the organization operated on donations and fundraisers (Anderson, 2011). In September 2010, VOZ tapped into Portland's wildly popular food cart scene. The group opened, Tacos El Jornalero, a taco truck on the day labor site (Bingham, 2010b). All its cooks are day laborers. They volunteer for two morning shifts during the busiest hours from 7 to 9 a.m. Their efforts put them at the top of the list when someone stops the next morning looking for a worker (Bingham, 2010b). The Archdiocese of Portland gave the cart operation a $\$ 5,000$ anti-poverty grant as part of the Catholic Campaign for Human Development program (Bingham, 2010a).

\section{Asylum and amnesty for unauthorized foreign in-migrants}

Unlike Sacramento, Portland did not weigh-in on the criminalization of Central American asylum-seekers. Local officials were, however, moved to act on the issue of amnesty and a controversial piece of legislation known as H.R. 4437. As 8,000 people took to the streets of Portland to protest Congressional efforts to enact that bill, Mayor Tom Potter lobbied to prevent the law from passing.

\footnotetext{
${ }^{296}$ Adams, who took heat from some Latino leaders for resisting their preference for renaming North Interstate Avenue after Chávez, has shown more caution around immigration issues than Potter (Pein, 2008a).
} 
He sent a letter to Oregon's Congressional delegate urging them to oppose Senator Sensenbrenner's H.R. 4437. A bill he said, would "criminalize millions of hard working, tax-paying undocumented immigrants, and drive them further underground" (Potter, 2006, para. 1). ${ }^{297}$ The April 10, 2006 letter, which Potter posted on his website, he also encouraged Oregon representatives to support the Senate Judiciary Committee Bill (which creates an earned path to citizenship for undocumented workers), and the DREAM Act amendment to that bill.

In his last year in office, Tom Potter became the first and only mayor in the United States to sign a proclamation declaring July 17 as International Justice Day two years in a row (AIUSA, 2008). Potter urged all Portland residents to observe the date and participate in activities to advance justice, and peace and security. Echoing Martin Luther King's statement, which is engraved in concrete on the Federal Justice Center building across the street from the Mayor's office, Potter said: 'If we don't have equity and justice for everyone, we don't have it for anyone.' (AIUSA, 2008).

${ }^{297}$ The bill would classify immigrants and anyone who helped them enter or remain in the U.S. as felons. 236 


\title{
CHAPTER 6
}

\author{
Comparison and Theory Evaluation
}

This chapter starts with a description of the similarities and differences among the unauthorized immigration policies of three U.S. cities: Sacramento, California; Denver, Colorado; and Portland, Oregon, as summarized in Table 3. It then goes on to explore the theoretical expectations presented in the study to see if correlations emerge in the data. The chapter concludes with a section on lessons learned.

\section{Intercity Policy Similarities and Differences}

In the cities studied, the "illegal" status of immigrants did not create barriers to community membership or equitable access to key services. Local governments in Sacramento, Denver and Portland were "responsive" to the needs and preferences of unauthorized immigrants; city officials proactively initiated policy with positive outcomes for this vulnerable population group. They took steps to guarantee residents without legal status membership in the city's polity, and with that, the civil rights and liberties associated with citizenship, including deportation relief. This political commitment is grounded in principles expressed by one of the slogans of the Immigrant Workers' Freedom Ride: "No human is illegal."

These "human rights cities" differ largely in their policy priorities, approach, and timing. On the first difference, timing, each municipality entered the immigration policy arena at different points in time. Sacramento adopted its first local citizenship policy in 1985, followed by Portland in 1992, and Denver in 1998. Policymakers in Portland acted 
to safeguard their own interests, more than the interests of foreign in-migrants, with respect to policies produced prior to 2005 . Earlier policies benefited foreign-born residents, but the primary intent was to protect the city from lawsuits involving police. Another difference relates to policy priorities. Issues related to citizenship (asylum and amnesty) were most important in Sacramento, but were given little or no attention in the other two cities. Unregulated migrant day labor, on the other hand, was barely discussed in Sacramento, while dangers related to day labor-contractor market exchanges were considered a big problem in Denver and Portland. Concern about the social welfare of noncitizens was not apparent in Portland. The city generated no policies on the matter, though it was a major policy issue in the other two cities. Worksite deportation raids appeared on Portland's the policy agenda. It was a nonissue in Sacramento and Denver. Debates about police involvement in civil immigration law enforcement were prominent in all three cities, but most contentious in Denver. Denver was the only city with policy on identification cards for foreign nationals.

Municipal policy approach was also an area of variance. Most of the immigration strategies initiated in Sacramento were unbinding resolutions, while the other two cities opted for methods offering more legal protection--executive orders and ordinances. Also, policymaking in Denver and Portland was piecemeal, while the California city took a blanket approach. Degree of transparency is one more field of dissimilarity. Sacramento openly embraced its so-called "sanctuary city" label, whereas Denver repeatedly denied it. The issue of sanctuary protections for unauthorized immigrants did not get a lot of 
attention in Portland, likely due to the relative absence of organized anti-illegal immigrant groups.

Why have each of these cities pursued a sanctuary-oriented policy direction? What accounts for the nuances in their actions on unauthorized immigration? I will attempt to answer those questions next.

\section{Exploring Theoretical Expectations}

This section sets forth and tests my policy model in all three cities. My approach is consistent with what Karl Hempel (1965) might call a "deductive-nomological" explanation. In offering this explanation, I examine how three cities match up to my theory-derived variables and deduce some key observations. My theoretical framework posits the following propositions.

Proposition 1: Municipal immigration politics and policy choice are shaped by a city's ethnoracial composition and configuration, which can which can be broadly delineated into three types according to degree and level of racial and ethnic diversity: homogeneous, heterogeneous, and bifurcated. ${ }^{298}$ Since policymaking occurs within the broader system of racial and ethnic stratification, local governments can be expected to initiate immigration strategies that reflect and reinforce their city's racial and ethnic structure. City governments in homogeneous locations will, under threatening conditions, adopt policies that protect Anglo interests over those of nonHispanic white immigrants. If

\footnotetext{
${ }^{298}$ Homogeneous jurisdictions are comprised of a dominate Anglo group — which includes all non-Hispanic English-speaking whites, regardless of their religion or ethnicity-- and a very small (less than 40 percent) minority population. Heterogeneous municipalities are characterized by the presence of multiple, more or less equally-sized racial/ethnic groups. Bifurcated cities have a relatively equal-sized Anglo and minority population, but, unlike multiethnic localities, one minority group is significantly larger than the others (Toussaint, 2013).
} 
the dominant group does not feel threatened by these newcomers the probability of a nativist reaction in reduced. Public officials in heterogeneous jurisdictions can be expected to take legislative steps to protect the rights and interests of minority immigrants - legal and unauthorized, if the situation warrants it. In a bifurcated environment, policy decisions will be determined by the ethnic/racial group with the most influence. Given that racial and ethnic populations are not equally distributed across the United States, and dominant-minority stratification arrangements vary as well, these different diversity patterns (heterogeneous, homogeneous, and bifurcated) account for city-to-city variation in policy outputs.

Findings: In light of my sample size, and the fact that there is no variance in the general outcome (all three cities were "responsive" to unauthorized immigrants), I would not even hazard a guess about the implications that social diversity might have on policy choice.

Where my sample has variation in outcome (policy approach) this factor correlated. Intercity differences in ethnoracial structure accounted for differences in the policy approach of the three case study cities. Unlike Denver and Portland, most of the sanctuary policy produced in Sacramento carried no legal weight; non-binding resolutions were most common. Elected officials used these moral statements to publicly express their constituents' disapproval of legislation that they had no vote on, rather than to regulate the behavior of city residents. Formal laws are not necessary when those with the power to get things done-elected officials, police, and social workers — can readily identify with and understand the interests of unauthorized minority immigrants. 
Sacramento's open embrace of its "sanctuary city" status is also related to its multicultural context. In spite of challenges from immigration foes, there was no need to deny it. Most everyone thought it was the right thing to do; there was little chance of polarizing the community. This collective consensus allowed city officials to take a more holistic policy approach than was possible in the other two cities. The city's sanctuary plan integrated protection for immigrants into municipal operating practices in one swoop. It provided a conceptual framework which could be applied whenever a new threat to the city's unauthorized population occurred, which reduced the need to adopt new polices. That would be improbably in a less diverse community.

In a city with little racial or ethnic diversity, like Portland, piecemeal policy is a wise approach. It reduces the likelihood that the dominant Anglo group will feel threatened by measures intended to protect minority immigrants; if the nonHispanic white group does not feel threatened, then the probability of a nativist reaction is reduced. And since minorities are not well-represented in politics or public institutions, there is a greater need for formal policy with legal sanctions in Portland. Relatively little diversity also contributes to Portland's lack of defensiveness about its "sanctuary city" label. There are too few minorities in the Portland to alter the city's social or political hierarchy—-that and the fact there are no well-organized anti-illegal immigrant groups to speak of in Portland.

In bifurcated Denver, the potential for competitive politics explains the city's secretive, piecemeal approach and strong preference for executive orders and ordinances (enacted without public testimony). 
In conclusion, differences in the ethnoracial structure of cities (homogeneous, bifurcated, and heterogeneous) accounted for variations in the policy approaches of local government. A larger study with more variable outcomes could help determine which of Hero's patterns merit further investigation.

Proposition 2: A local government's capacity to act on policy preferences is dependent upon its ability to form an urban regime with immigration purposes. ${ }^{299}$ If local leaders can build an urban regime to co-produce immigration policy capacity, then that city will have the social production power to take on major immigration initiatives. Without such a governing arrangement, little or no immigration policy will be produced locally. Since regime development does not occur at the same time across the country (due to variations in urban contexts), difference in regime development patterns-present or not present - explain variation in municipal immigration policy outputs (some or none), and the point in time when immigration policymaking begins.

Findings: Local governments in Portland, Denver and Sacramento adopted immigration policies. Yet, I find no evidence of direct business participation in the relevant coalitions of the three case cities, ${ }^{300}$ which Stone (1989) argues must be included to qualify as an urban governing regime. But my data may not be well suited to that factor. It misses important indirect channels of business influence that are present when policy initiatives do not constitute a major challenge to business interests. This was the

\footnotetext{
${ }^{299}$ The formal structure and rules of city government often makes it difficult for local officials to act.

${ }^{300}$ In Portland, businesses directly affected by day labor congregation in their parking lots joined a coalition to build a formal work site. But their involvement was short-term and limited to this single issue, which does not fit the definition of an urban regime partnership.
} 
case in the cities that I studied. Undocumented-friendly policy did not threaten business interests.

Data suggests, on the issue of immigration, business interests stepped back allowing progressive regimes to more directly dominant the city's policy agenda. In each of the three case cities, a regime devoted to expanding opportunities for unauthorized immigrants emerged with support from local social movement organizations ${ }^{301}$ and national lobby groups. ${ }^{302}$ An innovative mayor facilitated coalition formation. These progressive coalitions have remained stable for many years and across a number of administrations: thirty years and five mayors in Sacramento, ${ }^{303}$ twenty-two years and four mayors in Denver, ${ }^{304}$ and eight years and two mayors in Portland. ${ }^{305}$

More qualitative research could help identify areas of indirect business involvement in local immigration policymaking, such as: helping struggling economies adapt to the neoliberal environment by providing employment opportunities for unauthorized immigrants (Fluery-Steiner \& Longazel, 2010); offering grants to local organizations that provide services for this oft exploited workforce; or hiring third parties

\footnotetext{
${ }^{301}$ Social movement organizations are "associations of persons making idealistic and moralistic claims about how personal or group life ought to be organization that, at the time of their claimsmaking, are marginal to or excluded from... the dominant construction of what is realistic, reasonable, and moral" (Lofland, 1996, pp. 2-3).

${ }^{302}$ SMOs generally have the institutional resources - professional leadership, financing, an office and phone, publication, a list of members, and other accruement — needed to mobilize action for social change (Lofland, 1996, 12).

${ }^{303}$ List of Sacramento mayors: Anne Rudin (1983-1992); Joe Serna, J. (1993-1999); Jimmie Yee (19992000); Heather Fargo (2000-2008); and Kevin Johnson (2008-present). Before becoming mayor, Joe Serna Jr. served 11 years on the Sacramento City Council.

${ }^{304}$ List of Denver mayors: Wellington Webb (1991-2003); John Hickenlooper (2003-2011); Guillermo "Bill” Vidal (2011); and Michael Hancock (2011-present). Mayor Federico Peña (1983-1991) is not included in the list, because no major immigration initiatives were pursued during his tenure, although he likely paved the way for future political leader.

${ }^{305}$ List of Portland mayors: Tom Potter (2005-2008); and Sam Adams (2009-2012). Mayor Charlie Hales is not included in the list, because he was not elected until January 1, 2013.
} 
to sway public policy through corporate-funded research, campaign contributions and constituent lobbying. Additional studies would also help us better understand the origins, organization, dynamics and effects of progressive regimes with immigration purposes.

Proposition 3: Municipal policy on unauthorized immigration is shaped by local political ideology. There are two main political orientations in the United States-liberal (typically associated with the Democratic Party) and conservative (characteristic of the Republican Party). Liberals believe unauthorized immigrants should have the same rights as United States citizens. They expect government to protect the civil liberties and human rights of all people, regardless of nationality or citizenship. Conservatives oppose "sanctuary policies" for unauthorized immigrants. They believe those who break the law by entering the U.S. illegally do not have the same rights as citizens, or immigrants who obey the law by entering legally ("Conservative vs. Liberal,” 2010). Accordingly, local governments in cities with a liberal political culture are more likely to pursue urban citizenship policies $^{306}$ than city officials in places with a more politically conservative outlook, if committed leadership from a policy entrepreneur exits. Without such a change agent, liberal ideals are less likely to be translated into action. Since local political culture and political leadership varies across cities within the same country, these different political patterns explain intercity similarities and differences in strategic policy direction.

\footnotetext{
${ }^{306}$ These measures guarantee unauthorized immigrants formal membership in a city's polity, and with that, the civil rights and liberties associated with citizenship (Varsanyi, 2006), including freedom from deportation.
} 
Findings: Analysis of policy on unauthorized immigration in the three case study cities supports notions about local political culture shaping policy decisions governing the rights of foreign nationals without legal status.

Portland, Denver and Sacramento are left-leaning "blue cities," meaning the majority of municipal residents vote for candidates from the Democratic Party in a general election. ${ }^{307}$ Consequently, Democrats control city government and uphold liberal principles, including the idea that no human is illegal. Local governments in all three cities took legislative steps to promote and protect the civil rights and liberties of unauthorized city residents; a policy preference guided by human rights norms. ${ }^{308}$

Another critical factor that the three cities share in common is the skilled and committed leadership of a local policy entrepreneur. A policy entrepreneur is an individual —in or out of formal government—who exploits an opportunity in order to introduce innovative policy and influence its adoption without regard for the absence of resources required to take on such activity (Mintrom \& Norman, 2009, pp. 652-654; Cohen, 2012, p. 10); like other entrepreneurs, they act in conditions of risk and uncertainty (Hart, Stevenson \& Dial, 1995, p. 53).

The capacity to take action on unauthorized immigration in all three case cities can be traced to the emergence of a local policy innovator with a human rights agenda: Mayor Tom Potter (Portland), Mayor Wellington Webb (Denver), and

\footnotetext{
${ }^{307}$ I applied the concept of "red states" and "blue states" to cities. According to Wikipedia, red states and blue states refer to those U.S. states whose residents predominantly vote for the Republican Party (red) or Democratic Party (blue) presidential candidates. The terms were coined by journalist Tim Russert during his televised coverage of the 2000 presidential elections. Since then, usage of the term has been expanded to differentiate between states being perceived as liberal and those viewed as conservative.

${ }^{308}$ Human rights are commonly understood as "inalienable fundamental rights to which a person is inherently entitled simply because she or he is a human being" (Sepúlveda et al, 2004). Human rights are universal (applicable everywhere) and egalitarian (the same for everyone).
} 
Councilman/Mayor Joe Serna Jr. (Sacramento). ${ }^{309}$ Legal protections for unauthorized immigrants were not considered or adopted until these men were elected. ${ }^{310}$ It was these policy innovators who translated liberal human rights principles into action. They took up the immigrants' rights cause and made it part of the local political agenda before other city officials were fully onboard. These mayors also carried out the entrepreneurial tasks of identifying a "window of opportunity" (Kingdon, 1997) for introducing the idea of municipal policy on unauthorized immigration; developing a rationale for local intervention in international immigration affairs; formulating a context-specific policy design and implementation plan; attracting broad base political support; building momentum for policy adoption; and using their power of translation to persuade decisionmakers to take legislative action.

\footnotetext{
${ }^{309}$ The timing of this innovator's appearance coincided with increases in the number of minorities living within each city, and the subsequent need to protect unauthorized minority immigrants from federal policies harmful to this vulnerable population group.

${ }^{310}$ Early immigration policy produced in Portland, Oregon was adopted in response to lawsuits. Local government acted to protect the city from liability, not to protect vulnerable foreign in-migrants.
} 


\section{Lessons Learned}

A number of lessons can be drawn from the cases studied. Here are some of the factors that promote successful adoption of policy to protect unauthorized immigrants:

1. The presence of a risk-taking leader devoted to social justice. Inclusive policy is most likely to succeed where a policy entrepreneur is present. In the three cities studied, capacity to take action on unauthorized immigration can be traced to the emergence of a local policy entrepreneur. In each case, these political innovators lead by example. They took a potentially risky policy stand on unauthorized immigration before other city officials were fully on-board. Laying their political careers on the line for the immigrant rights cause helped mobilize institutional insiders and attract coalition partners.

2. Broad-based coalition building. To build capacity to take on major immigration initiatives, city officials must commit to building a complex web of unlikely alliances across multiple racial lines and social movement organizational sectors. In the cities that I studied, mayors sought this kind of support.

3. Human rights claim making. To gain broad-base support, focus on human rights issues rather than narrow political interests like immigrants' rights. The mission of many ethnic networks and SMOs fit under the human rights umbrella. Mayors in Sacramento, Denver and Portland used humanitarian arguments to define injustices against unauthorized immigrants, build community consensus that this was a problem, and lay out a plan for ameliorative action. Los Angeles Times 
political columnist George Skelton (1999) noted how Sacramento Mayor Joe

Serna Jr. exemplified this approach.

Serna showed that you can make it politically without pandering to ethnic constituencies, without playing to your 'community.' His only community really was the 400,000 citizens of Sacramento, as Pollyannaish as that may seem to critics...And that was Sacramento's sense of him - that and a sense of his exercising fairness, rather than favoritism (paras. 7, 9).

4. Place-specific policy approach. Inclusive policy outputs are more likely when the policy approach matches the social context. In a city with little diversity, or where the potential for competitive politics is high (as in a racially bifurcated setting), a piecemeal policy approach is wise. It reduces the likelihood that the dominant Anglo group will feel threatened by measures to protect minority immigrants. There is also a greater need for strong legal sanctions in racially homogeneous or bifurcated cities than in multiethnic places, where the need to regulate racially biased behavior is less.

5. Incorporate newcomers into the local political system. Initiate a hiring plan to ensure that first generation immigrants are well-represented in government agencies and institutions. This reduces the need for formal policy on unauthorized immigration. Laws are not necessary when those with the power to get things done-elected officials, police, and social workers—can readily identity with and understand the interests of unauthorized immigrants. This was the approach taken in Sacramento, where the equitable treatment of residents without legal status was controlled, for the most part, by informal community norms. 
6. Encourage citizenship. Establish a program to assist foreign-born residents become citizens. Local government in Sacramento, California used this strategy to increase political support for programs and policies affecting unauthorized city residents

7. Take back the facts. To sustain policy in the face of opposition, use research to refute a challenger's disinformation campaign. In Sacramento, sanctuary foesnational anti-immigration lobby groups, members of the legal community, and regional INS directors- dropped their campaign to recall policy backers, and overturn Sacramento's "City of Refuge" policy, after research conducted by a task force disproved their claims.

8. Tell the truth and do it fast. Immediately and directly contradict disinformation via a point-for-point rebuttal of the opponent's propaganda allegation. Denver used this strategy to withstand a fierce, decade-long campaign to resend the city's policies on foreigners waged by state and federal congressional members, national anti-immigrant lobby coalitions, and radio talk show hosts. Elected and appointed officials in Sacramento also employed this tactic. 


\section{CHAPTER 7}

Contributions, Limitations and Future Directions

Municipal immigration policy is happening all around us, but it is ad hoc from city to city and not well understood. More research is needed to help us understand this increasingly important dimension of immigration policy. My research helps fill this gap in scholarship.

The dissertation addresses two questions. First, what unauthorized immigration policies do local governments pursue, under what circumstances, and for what reasons? Second, what explains intercity variation in municipal responsiveness to the policy preferences and interests of residents without legal status?

\section{Multicity Policy Exploration}

To answer the first question, I conducted multicity exploratory policy research. I gathered data on policies adopted and considered by U.S. city governments in response to seven hotly debated, locally important immigration issues: asylum for unauthorized refugees, worksite deportation raids, government benefits for noncitizens, devolution of immigration law enforcement, "locally legal" identification cards, unregulated day laborcontractor market exchanges, and amnesty for unauthorized immigrants.

I found that there are far more positive responses to these issues than negative examples. Cites crafting policies to protect the rights of residents without legal status have been at it longer (since the 1980s), than localities with deter and deflect settlement agendas, which only emerged in the last decade. Local officials in cities with lots of 
diversity and foreign-born residents, and governments in places with little of either, generated both kinds of policy.

The policy direction pursued by municipal authorities - pro- or anti-unauthorized immigrant—was shaped by city political culture — liberal or conservative. Either way, municipal policy development coincided with federal action (or inaction) on unauthorized immigration. The aim of these measures is three-fold: to address controversial local issues associated with unauthorized immigration; effectuate change in public opinion on the topic; and urge local governments in other cities, or at the state and federal level, to shift their policies in accordance with local ideas about the rights of residents without legal status.

The day labor issue generated the largest volume of policy action on both sides of the debate, followed by post-9/11 devolution of immigration law enforcement. Asylum for unauthorized refugees and federal deportation raids also sparked a lot of local policy action, most of it on the pro-sanctuary side. The issue of public benefits for noncitizens caused a great deal of controversy but far fewer policies were considered or passed. The fewest policies are those related to "locally legal" identification cards and amnesty for unauthorized immigrants. In all areas, intercity policy copycatting is common and involves a range of tactics well beyond those represented in existing literature.

This research verifies and expands existing policy data, most of which is based on a limited pool of municipal tactics and drawn from patchy secondary sources. My policy inventory situates responses to seven different hot button issues under one umbrella. It reveals previously unidentified policy strategies, and covers a twenty-five year period. 
The typology that I constructed from this data will make future comparative study easier. It can used to guide data collect and classification. Still, it has some limitations.

Empty cells in the matrix highlight a key limitation of the multicity policy research: missing policy information and how to account for it. There is no way of knowing whether the absence of a policy means a city is unwilling, or unable, to take action in that area. The issue may have been addressed by a nongovernmental agency or other level of government. The rationale for the presence of a policy is also unknown. Does a policy benefiting foreign in-migrants always mean that was the intent, or was a potential lawsuit the motivation? Also sometimes policies that appear immigrant-friendly may not be. For instance, to encourage use of a formal hiring hall a city might prohibit soliciting work on sidewalks. This can hurt day laborers if employers do not use the hiring center. More descriptive and contextual depth is required to make these kinds of distinctions. A comprehensive comparison of cities is not possible with the data available in my inventory. Case studies are needed.

\section{Multiple Case Study Research}

To answer my second research question, I conducted a theory-driven, comparative case study of local government response to unauthorized immigration in three U.S. cities: Sacramento, California; Denver, Colorado; and Portland, Oregon. These issues were the same topics included in my exploratory policy study.

I found that, despite differences in the racial and ethnic structure of these cities, local governments in all three municipalities were "responsive" to the needs and preferences of residents without legal status. A liberal political culture, as expressed 
through entrepreneurial political leaders, has been important in shaping regime development and policy action on unauthorized immigration in these cases.

In each city, greater responsiveness to unauthorized immigrants can be traced to the emergence of a policy entrepreneur with an immigrants' rights agenda; prior to this time, no protections for residents without legal status were considered or adopted. These political innovators used humanitarian arguments to rally together enough support from social movement organizations, and national lobby groups, to carry out their inclusive policy agenda — expanding opportunities for unauthorized immigrants. The progressive regimes that they built held fast during economic downturns, and across numerous political administrations.

The policy approach taken by these entrepreneurial mayors and their allies varied city-to-city, and was shaped by the ethnoracial composition and configuration of each locality. Multiethnic Sacramento openly embraced its "sanctuary city" status, produced mostly nonbinding resolutions, and took a blanket policy approach. Bifurcated Denver and homogenous Portland relied on a binding, piecemeal policy strategy, albeit for different reasons.

My case study research thus supports and refines previous research that emphasizes political factors: political mobilization, partisanship and policy entrepreneurship. It substantiates claims made by Miriam Wells (2004) about the de facto role that local government plays in the immigration regime, which is to adjust federal policy in accordance with local ideology and interests. It also supports Ramakrishnan and Wong's (2010) empirically-based hypothesis about political affiliation, which is that 
Democratic counties (and by extension, cities) are less likely to pursue anti-illegal immigration policies than Republican areas. Moreover, the research underscores the importance of urban political leadership and SMOs in local governance; insights that contribute to scholarly discussions about the explanatory usefulness of the urban regime model, and the budding body of empirical literature on policy entrepreneurship. ${ }^{311}$

My dissertation also fills a gap in the emerging literature on new immigrant destinations by describing and explaining what is happening in reemerging immigrant gateways. New immigrant destinations with a progressive stance on the membership of unauthorized immigrants have not been extensively studied. The findings also highlight the "liberty-enhancing" role city government can play in protecting the rights and liberties of non-U.S. citizens and in doing so, adds to the discussion on immigration federalism, which has focused primarily on local immigration controls. By zeroing in on local responses to unauthorized immigration issues, I have generated a richly detailed and deep elaboration of this particular aspect of municipal foreign policy, contributing to international relations scholarship. Finally, my insights about a city's human rights valueorientation shaping policy choice might focus more attention to culture in the study of contemporary immigration.

I have also drawn lessons from the cases studied that might prove useful in other similarly situated cities. These suggestions could inform the decisions of urban planners, community organizers, public administrators, and municipal policymakers. Also, by

311 See Baumgartner \& Jones, 1993; Kingdon, 1997; Oliver \& Paul-Shaheen, 1997; Mintrom 1997, 2000; Edwards, C., Jones, G., Lawton, A., \& Llewellyn, N., 2002; Mintrom \& Norman 2009; Huitema \& Meijerink, 2010; Cohen, 2012; Niedhardt, 2012; Seifert, 2012. 
highlighting the urban aspects of national immigration policy, my research could promote greater involvement of local government in federal policy discussions, and consequently, more "city-friendly" foreign policy. The study will certainly challenge the assumption that localities are powerless over immigration processes imposed from above. City governments across the United States act autonomously to adjust federal immigration policy in accordance with local interests, and in doing so allow for finer regulatory controls than the one-size-fits-all policy that can be implemented at the national level. These "second-order immigration regulations...provide a means by which, in the absence of a national consensus, the competing interests surrounding immigration can still be negotiated and regulated" locally (Su, 2010, p. 370). 


\section{REFERENCES}

Abbott, C. (2001). Greater Portland: Urban life and landscape in the Pacific Northwest. Philadelphia, PA: University of Pennsylvania Press.

Abu-Laban, Y. \& Garber, J. A. (2005). The construction of the geography of immigration as a policy problem. Urban Affairs Review, 40(4), 520-561.

Aguilar, L. (2000a, December 3). Migrant labor, abuse reports increase. The Denver Post, p. L1.

. (2000b, December 5). Informal day-labor pickup sites spur concerns. The Denver Post, p. L1.

. (2001, January 21). Growth fuels boom for Hispanics. The Denver Post.

Retrieved from http://extras.denverpost.com.

Aguilar, L. \& Simpson, K. (2002, December 1). Working for the future. The Denver Post, p. A1.

Aguilera, E. (2005a, July 25). Zeroing in on anti-immigrant sentiment. The Denver Post, p. B3.

. (2005b, November 1). Battle over immigration set up for '06. The Denver Post, p. B1

. (2005c, November 16). City works on day-laborer wage protection. The Denver Post, p. B1.

. (2005d, November 17). Wage-theft law clears committee. The Denver Post, p. B3.

. (2006, May 5). New law raises profiling fears. The Denver Post, p. B2.

. (2007, May 2). Stepping up for change: Immigrants, backers march for U.S. citizenship, families, respect. The Denver Post, p. B1.

Aguilera, E. \& Sanchez, R. (2005, August 12). Where filth and freedom collide. The Denver Post, p. A1.

Albuquerque Community Service and Planning Department. (1994). Barelas neighborhood commercial area revitalization plan, 1994. Retrieved from http://www.cabq.gov/planning/publications. 
Alcala, C. (1996, January 20). 2,000 take oath for citizenship. The Sacramento Bee, p. A1.

Alexander, M. (2003). Local policies toward immigrants as an expression of HostStranger relations: A proposed typology. Journal of Ethnic and Migration Studies, 29(3), 411-430.

. (2004). Comparing local policies toward migrants. In Rinus Penninx, Karen Kraal, Marco Martinielo, and Steven Vertovec (Eds.), Citizenship in European Cities (pp. 57-84). Aldershot, UK: Ashgate.

. (2007). Cities and labour migration. Aldershot, UK: Ashgate.

Alleged cop killer an illegal alien. (2005, May 11). WorldNetDaily (WND). Retrieved from http://www.wnd.com.

Allott, A. (2002, November 10). Why not id cards? The Denver Post, p. E3.

Altshuler, A. \& Luberoff, D. (2003). Mega-projects: The changing politics of urban public investment. Washington, DC: The Brookings Institute.

Alvarado, P. (2003, June 9). Learning from Farmingville: Promising practices for immigrant workers [Forum transcript]. Washington, DC: The Brooking Institute Center for Urban and Metropolitan Policy. Retrieved from http://www.brook.edu.

American Civil Liberties Union [ACLU]. (2003, November 14). Sacramento goes on record opposing the USA Patriot Act. Retrieved from http://www.aclu.org. . (2004, June 10). List of communities that have passed resolutions. Retrieved from http://www.aclu.org.

. (2007, March 6). Proposed Suffolk County Law unfairly criminalizes day laborers, NYCLU testifies. Retrieved from http://www.aclu.org.

American Civil Liberties Union of Colorado. (2005, May 24). ACLU letter to Denver officials (explaining why Denver should withdraw from FBI JTTF). Retrieved from http://aclu-co.org.

.(n.d.). The FBI's Joint Terrorism Task Force. Retrieved from http://aclu-co.org.

American Civil Liberties Union of Oregon (n.d.). Archive: FBI's Joint Terrorism Task Force (2001-2008). Retrieved from http://www.aclu-or.org. 
American Civil Liberties Union of Sacramento urges city council to oppose Arizona immigration law. (2010, May 26). News Blaze. Retrieved from http://newsblaze.com.

American Friends of Service Committee [AFSC], Denver, Colorado. Colorado immigrants rights program. Retrieved from https://afsc.org/office/denver-co.

American Patriot Friends Network. (2003, May 27). Colorado bans Mexican ID cards. Retrieved from http://www.apfn.com.

Americans Voice Online. (2009, October 26). Warning: Talking about immigration sanely maybe hazardous. Retrieved from http://americasvoiceonline.

Amnesty International USA [AIUSA]. (2008, July 28). Portland Mayor Tom Potter proclaims July 17 as International Justice Day. Retrieved from http://aipdx.org.

Anderson, D. R. \& Hogan, D. (1996, January 25). Police hit downtown drug dealers. The Oregonian, p. D1.

Anderson, J. (2007a, June 15). Immigration anxiety hits home, stays hot. Portland Tribune. Retrieved from http://portlandtribune.com. . (2007b, July 24). Portland to set up day labor hire site. Portland Tribune. Retrieved from http://portlandtribune.com.

. (2007c, July 31). Laboring for answers at day-labor site. Portland Tribune. Retrieved from http://portlandtribune.com.

. (2007d, December 7). City moves closer to setting up day labor hiring site. Portland Tribune. Retrieved from http://portlandtribune.com.

. (2008a, March 4). Neighbors not wild about day labor site. Retrieved from Portland Tribune. http://portlandtribune.com.

. (2008b, June 16). Work trickles in as day labor site opens. Portland Tribune. Retrieved from http://portlandtribune.com. . (2008c, July 7). Protester roughed up outside city day labor site. Portland Tribune. Retrieved from http://portlandtribune.com.

. (2008d, July 24). Day-labor site falls down on the job. Portland Tribune. Retrieved from http://portlandtribune.com. 
. (2008e, August 2). Potter on notice over day labor issue. Portland Tribune. Retrieved from http://portlandtribune.com.

. (2008f, August 20). Grant hopes to put human face on day labor site. Portland Tribune. Retrieved from http://portlandtribune.com.

. (2011, September 1). Laborers hold out hope. Portland Tribune. Retrieved from http://portlandtribune.com.

Appleseed. (n.d.) Forcing our blues into gray areas [Legal guide]. Washington, DC: WilmerHale. Retrieved from http://www.appleseeds.net.

Arab Community Center for Economic and Social Service. (2004, December 29). City of Dearborn opposes the CLEAR Act. Retrieved from http://www.jihadwatch.org.

Archibold, R. C. (2007, December 4). Phoenix mayor shifts on officers' asking for immigration status. The New York Times. Retrieved from http://www.nytimes.com.

Armstrong, S. (1990, May 14). Worker center split Californians. The Christian Science Monitor, p. 6.

Arthur, K. \& Lingle, C. (2001, November 29). Day laborers going unpaid City seeks grants for help center. The Denver Post, p. B1.

Attig, R. (2001, December 2). Portland in the eye of a maelstrom [Editorial]. The Oregonian, p. B1.

Austin, M. (2000, March 12). Colorado looks south to fill jobs. Denver Business Journal. Retrieved from http://www.bizjournals.com.

Bach, R. (1993). Changing relations: Newcomers and established residents in U.S. communities. New York, NY: Ford Foundation.

Bacher, D. (2003a, October 2). Sacramento becomes first inland city in California to adopt a living wage ordinance. Dissident Voice. Retrieved from http://dissidentvoice.org. . (2003b, November 15). Sacramento joins 209 cities in opposition to Patriot Act. Dissident Voice paea. 2. Retrieved from http://www.dissidentvoice.org.

Bahrampour, T. (2010, May 7). Prince William immigration law remains controversial. The Washington Post, para. 11. Retrieved from http://www.washingtonpost.com. 
Bailey, R. W. (1999). Gay politics, urban politics: Identity and economics in the urban setting. New York, NY: Columbia University Press.

Baker, H. (2005, July 24). Our cities need kids. The Denver Post, p. E1.

Bancroft, A. (1993, October 15). New firebombing in Sacramento. The San Francisco Chronicle, p. A21.

Bau, I. (1994). Cities of refuge: No federal preemption of ordinances restricting local government cooperation with the INS. La Raza Law Journal, 7(1), 50-71.

Bauböck, R. (2003). Reinventing urban citizenship. Citizenship Studies, 7(2), 139-160.

Bauroth, N. (1998). Regime approaches to obscenity policy: 1960s to 1980s. Journal of Urban Affairs 20, 395-417.

Baumgartner, F. \& Jones, B. (1993). Agendas and instability in American politics. Chicago, IL: Chicago University Press.

Bay Area Center for Voting Research [BACVR]. (n.d.). The most conservative and liberal cities in the United States. Berkeley, CA: Author. Retrieved from http://alt.coxnewsweb.com/statesman/metro/081205libs.pdf.

Bazar, E. (2002, September 21). Card offers ID, banking access to immigrants. The Sacramento Bee, p. A1.

. (2003a, January 7). Program targeting Middle Easterners, Muslims protested at Sacramento INS office. The Sacramento Bee. Retrieved from http://www.sacbee.com.

. (2003b, January 8). INS registry sparks protest. The Sacramento Bee, p. B1.

. (2003c, January 20). New battle on civil rights front: The registration of some immigrants is denounced as racial profiling. The Sacramento Bee, p. A1.

. (2003d, February 19). Immigrant-control groups assail popular ID cards. The Sacramento Bee, p. A1.

. (2003e, November 12). Council may fire Patriot Act salvo. The Sacramento Bee, p. B1.

. (2003f, November 19). Patriot Act excesses: Sacramento City Council takes a stand. Sacramento Bee, p. B6. 
. (2004a, February 29). Region again is a major gate to the U.S. The Sacramento Bee, p. B1.

. (2004b, May 14). Police, feds may work in tandem. The Sacramento Bee, p. A1.

. (2004c, November 16). Valley's jobs, housing lure in-state migrants. Sacramento Bee, p. A1.

. (2008, June 20). West Coast mayors decry immigration raids. USA Today. Retrieved from http://www.usatoday.com.

Bazar, E. \& Armour, S. (2005, October 24). Cities tackle day labor dilemma. USA Today. Retrieved from htpp://www.usatoday.com.

Bazar, E., \& Stanton, S. (2003, October 22). City eyes Patriot Act stand. The Sacramento Bee, B1.

Beard, B. (2010, August 8). Boycotting Arizona is easier said than done. The Arizona Republic, p. D5.

Beaven, S. \& Hallman, T. (2007, June 21). Children of the raid. The Oregonian, Metro Portland Neighbors: In Portland, pp. 12-15.

Bee, C. (1991, February 1). Judge oks pact on immigration. The Sacramento Bee, p. A3.

Bee, M. (1995, January 29). Debate over welfare may change U.S. The Sacramento Bee, p. A1.

Beebe, D. (2001, December 8). Police chief caught in the middle. The Oregonian, p. B7.

Bell, T. (1994, November 16). Davis votes dictated Prop. 187's Yolo rejection. The Sacramento Bee, p. B4.

Bellantoni, C. (2005, August 19). Center staff won't check legal status of laborers. The Washington Times. Retrieved from http://www.washingtontimes.com.

Beller. P. C. (2005, November 22). Crackdown deters day labor employers. The New York Times, p. B4.

Benhabib, S. (2004). The rights of others: Aliens, residents and citizens. Cambridge, UK: Cambridge University Press. 
Berkeley Peace and Justice Commission. (2007, May 7). Minutes of the Peace and Justice Commission meeting [Meeting minutes]. Retrieved from http://www.ci.berkely.ca.us.

Bermudez, E. (2006a, August 31). Tempers collide on immigration. The Oregonian, p. A1.

. (2006b, September 8). Facing protests, day laborers move to organize. The Oregonian, p. B3.

. (2007a, July 27). Contractor wants voters to declare 'Legal Workers Only.' The Oregonian, pp. A1, A4.

. (2007b, December 12). Bracelet women scrape by. The Oregonian, p. C1.

. (2007c, December 12). Portland pitches in \$20,000 after raid. The Oregonian, p. C4.

Bernstein, D. (1987, March 6). Critics claim sanctuary policy review is flawed. The Sacramento Bee, p. B3.

Bernstein, M. (1999, March 12). Laborers ask moose to call off police. The Oregonian, p. D2.

. (2001a, November 22). State studies fed's request. The Oregonian, p. A1.

. (2001b, November 24). City wins ally in Ashcroft clash. The Oregonian, p. A1.

. (2001c, November 30). Portland officials say 5 questions in terrorism inquiry raised flags. The Oregonian, p. A1.

Bernstein M. \& Larabee. (2001, November 28). Police insist interviews illegal. The Oregonian, p. A1.

Bettis, R. (2003, November). LWVS and civil liberties. League of Women Voters of Sacramento, newsletter 59(10). Retrieved from http://www.lwvsacramento.org.

Bidwell, C. (1991, July 26). Resident voter plan debated GOP members push for noncitizen rights. Daily News of Los Angeles, p. T1.

Bill of Rights Defense Committee [BORDC]. (2007, December 7). Grassroots opposition the USA PATRIOT Act [List].Retrieved from http://www.bordc.org. 
. (n.d.). Resolutions and ordinances critical of the USA PATRIOT Act and other laws and policies that diminish civil liberties. Retrieved from http://www.bordc.org.

Bingham, L. (2010a, December 8). Anti-poverty grants awarded to Northeast Portland food cart, Eugene area small farmers. The Oregonian. Retrieved from http://www.oregonlive.com.

. (2010b, December 17). Northeast Portland nonprofit food cart run by day laborers hopes to find niche in trendy cart scene. The Oregonian. Retrieved from http://www.oregonlive.com.

Bisharat, P., \& Teichert, E. (2010, July 15). Report to Council, City of Sacramento. Proposed resolution opposing Arizona SB 1070 and HB 2162 [Staff report]. Retrieved from http://www.cityofsacramento.org/clerk/services/index.html.

Bizjak, R. (1991, May 10). Seniors, children booming in capital. Sacramento Bee, p. A1. . (1992, September 22). Capital's future? Sacramento Bee, p. B1. . (1996, August 21). Radio host denounced as 'hate crime' booster. The Sacramento Bee, p. B1. . (1998, April 17). Mayor's agenda: 'Human needs.' The Sacramento Bee, p. B1. . (2002, November 7). Venegas to step down as chief. The Sacramento Bee, p. A1.

Bizjak, T. \& Kollars, D. (1999, November 8). Mayor Serena dies at home. The Sacramento Bee, p. A1

Bizjak, T. \& Vierria, D. (1996, August 28). Remarks on radio talk show cost job. The Sacramento Bee, p. B1

Bizjak, T. \& Wong, J. (1991. February 27). Capital's population now 47\% minorities. The Sacramento Bee, p. B1.

Bjorhus, J. (1997, November 2). Joint efforts by police, INS concern immigrant-rights groups. The Oregonian, p. A1.

Blackmun, M. (1997, May 31). Activist charge INS tactics violate rights. The Oregonian, p. C1.

Blalock, H. 1967. Toward a theory of minority-group relations. New York, NY: Wiley. 
Blattberg, C. (2001). Political philosophies and political ideologies. Public Affairs Quarterly, 15(3), 193-217.

Bloemraad, I. (2002). The North American naturalization gap. International Migration Review, 23(1), 193-228.

. (2006). Becoming a citizen: Incorporating immigrants and refugees in the United States and Canada. Berkeley, CA: University of California Press.

Bodovitz. K. (1989, September 29). S.F. bill aimed at police: Plan to legislate sanctuary. The San Francisco Chronicle, p. A33.

Boone, R. (2005, July 29). Idaho County uses RICO to sue for hiring illegal immigrants. Associated Press in The Victoria Advocate. Retrieved from http://news.google.com/newspapers.

Borjas, G. (2002). Welfare reform and immigrant participation in welfare programs. International Migration Review, 36(4), 1093-1123.

Bourhis, R., Montaruli, E., El-Geledi, S., Harvey, S., \& Barrette, G. (2010). Acculturation in multiple host community settings. Journal of Social Issues, 66(4), 780-802.

Bowers, K. (1995, May 10). Crossing the line. Denver Westword News. Retrieved from http://www.westword.com.

Bowman, J. (2010, May 1). Hundreds protest Arizona immigration law in downtown Denver. Denver KDVR-TV. Retrieved from http://www.kdvr.com.

Bradford, H. (2011, November 4). America's young adults flocking to these seven cities: Brookings. The Huffington Post. Retrieved from http://www.huffingtonpost.com.

Brenner, N. (1999). Globalization as reterritorialisation: The re-scaling of urban governance in the European Union. Urban Studies, 36(3), 431-51.

Breton, M. (1998, April 13). Thousands of immigrants stuck in paperwork jam. The Sacramento Bee, p. A1. . (2009, October 25). Immigrant rights--one cop's view. The Sacramento Bee, p. B1.

. (2010a, May 5). Arizona law, Sacramento mayor's flip-flop angers ex-judge, The Sacramento Bee p. B1. 
. (2010b, June 23). Latinos led effort for city boycott. The Sacramento Bee, p. B1.

Brettell, C. (2008). 'Big D': Incorporating new immigrants in a Sunbelt suburban metropolis. In A. Singer, S.W. Hardwick, \& C. B. Brettell (Eds.), Twenty-first century gateways (pp. 53-86). Washington, DC: Brookings Institute Press.

Brettell, C., \& Nibbs, F. (2011, January). Immigrant suburban settlement and the "threat" to the middle class: The case of Farmers Branch, Texas. International Migration, 49(1), 1-30.

Briscoe, D. (2007, October 15). Return to Sender. Newsweek. Retrieved from http://www.newsweek.com.

Brockman, T. (2010, June 21). Columbus City Council sends immigration reform resolution to D.C. NBC4i. Retrieved from http://www2.nbc4i.com.

Broder, T. (2007, May). State and local policies on immigrant access to services. Oakland, CA: National Immigration Law Center. Retrieved from http://www.nilc.org.

Brooke, J. (1997, November 26). Crowd in Denver rallies against skinhead violence. The New York Times, p. A20.

Brooks, K. (2010, May 13). Austin passes Arizona boycott. KXAN-TV News. Retrieved from http://www.kxan.com.

Brookings Institute. (2002, February). Should legal immigrants receive public benefits? Retrieved from http://brookings.edu.

Brookings Institution, Center on Urban and Metropolitan Policy. (2003, November). Denver in focus: A profile from Census 2000. Retrieved from http://www.brookings.edu. . (2003, November). Portland in focus: A profile from Census 2000. Retrieved from http://www.brookings.edu.

Brosnan, G., \& Szymaszek, J. (Producers). (2009). In the shadow of the raid [DVD]. United States: Street Dog Media.

Brown, F. (1997, Dec. 21). Immigrants seldom 'major factor' in state. The Denver Post, p. A13. . (2005, July 17). Hick's honeymoon rolls on. The Denver Post, p. E6. 
Brown, J. (2006, March 9). First step toward solution. The Chicago Tribune. Retrieved from http://www.chicagotribune.com.

. (2006, May 2). A roar for respect local: 75,000 join Capital throng for 'We Are America.' The Denver Post, p. A1.

Brown, M., Carnoy, M., Currie, E., Duster, T., Oppenheimer, D., Shultz, M., \& Wellman, D. (2003). Whitewashing race: The myth of a color-blind society. Berkeley, CA: University of California Press.

Brownell, P. (2005, September). The declining enforcement of employer sanctions. Migration Information Source. Retrieved from http://www.migrationinformation.org.

Bruno, A. \& Storrs, K. (2005, May 26). CRS Report for Congress, Consular identification cards. Washington, DC: United States Congressional Research Service, The Library of Congress. Retrieved from http://www.fas.org.

Building boom won't quit. (2007, July 8). Sacramento Business Journal. Retrieved from http://www.bizjournals.com/sacramento.

Bureau of Justice Assistance (1993). Stopping the hate crime: A case history from the Sacramento Police Department [Factsheet]. Washington, DC: U. S. Department of Justice, Office of Justice Programs.

Burghart, T. \& McCall, W. (2000, September 1). The INS of "Deportland." Asian Week. Retrieved from http://www.asianweek.com.

Burke, A. (2008, April 6). Burke: Sanctuary cities undermine immigration laws. The Record Searchlight. Retrieved from http://www.redding.com.

Burnett, M. (2011, May 12). Seattle's new wage theft ordinance becomes effective June 4, 2011. No Vacancy: Duff on Hospitality Law. Retrieved from http://www.duffonhospitalitylaw.com.

Burrowes, V. (1990, March 6). Minutes Sacramento City Council regular meeting [Meeting minutes], 1-19. Retrieved from http://www.cityofsacramento.org/clerk/services/index.html.

. (1996, August 20). Minutes of the Sacramento City Council, Redevelopment Agency of the City of Sacramento, and Housing Authority of the City of Sacramento [Meeting minutes], 1-5. Retrieved from http://www.cityofsacramento.org/clerk/services/index.html. 
Burruss, L. (2010, September 10). U.S. circuit court rules against illegal immigration laws. Cable News Network. Retrieved from http://www.cnn.com.

Business gears up for immigration reform fray. (2006, December 3). Sacramento Business Journal. Retrieved from http://www.bizjournals.com/sacramento.

Cabell, M. 2007. Mexican integration in the U.S. Southeast: Institutional approaches to immigration integration in Owensboro, Kentucky [Working Paper No. 153]. University of California-San Diego: Centre for Comparative Immigration Studies.

California laws aim at illegal immigrants (1993, October 5). Associated Press in The New York Times, A-24.

California Proposition 187, Illegal Aliens Ineligible for Public Benefits, 1994 (2012). In Ballotpedia. Retrieved from http://ballotpedia.org.

Callahan, P. (1997, February 2). Reform swaps INS: Many chase citizenship to keep benefits. The Denver Post, p. A1.

Callaway, C. \& Bierbauer, C. (1996, December 17). Nation's mayors meet with President Clinton. Cable News Network. Retrieved from http://www.cnn.com.

California town can't release names of day-labor employers. (2007, July 12). Associated Press in The First Amendment Center. Retrieved from http://www.firstamenmentcenter.org.

Cambridge Peace Commission (2008, February 15). A message from the Peace Commission: Information on Cambridge's Sister Cities. Retrieved from http://www2.cambridgema.gov.

Colorado Alliance for Immigration Reform (CAIRCO). (2005, May). Press conference and protest of Denver sanctuary policy. Retrieved from http://www.cairco.org.

Capps, R., Castañeda, R., Chaudry, A., \& Santos, R. (2007, October 31). Paying the price: The impact of immigration raids on America's children. Washington, DC: Urban Institute. Retrieved from http://www.urban.org.

Caprio, G. (2010a, May 3). Immigration reform demonstrators rally in Sacramento. Sacramento Civil Rights Examiner. Retrieved from http://www.examiner.com. . (2010b, June 25). Group calls for Sacramento City Council recall. Sacramento Civil Rights Examiner. Retrieved from http://www.examiner.com. 
Cardona, F. (2005, October 24). Federal funding sought in cops' probe. The Denver Post, p. B1.

Carey, J. (2012, June 25). Prince William County immigration ordinance about enforcement: Stewart [Blog]. NBC Washington. Retrieved from http://www.nbcwashington.com/blogs.

Carlesso, J. (2010, May 7). Boycott Arizona? [Blog]. Hartford Courant Cityline. Retrieved from http://blogs.courant.com.

Carman, D. (2006, May 2). 'Ocean of beauty' too big to ignore. The Denver Post, p. B1. . (2007, May 1). Immigrant march gains urgency. The Denver Post, p. B1.

Castells, M. (1983). The city and the grassroots. Berkeley, CA: University of California Press.

Castillo, M. (2011, October 8). Against the grain, Dayton, Ohio, embraces immigrants. Cable News Network. Retrieved from: http://articles.cnn.com.

Castles, S. (2004). The factors that make and unmake migration policies. International Migration Review, 38(4), 852-884.

. (2010). Understanding global migration. Journal of Ethnic and Migration Studies, $36(10), 1565-1586$.

Cave, D. (2009, July 2). Big-city police chiefs urge overhaul of immigration policy. The New York Times, p. A13.

Centro Humanitaro para los Trabajodres [El Centro]. (n.d.). About Us. Retrieved from http://www.centrohumanitario.org.

Chacón, J. M. (2008). The security myth. In A. C. d'Appollonia \& S. Reich (Eds.), Immigration, integration, and security (pp. 145-163). Pittsburgh, PA: University of Pittsburg Press.

Chaddha, A. (2006, July/August). Rants and raves: Somalis demand equal access to education. Colorlines, 11.

Chance, A. (1986, January 29). TV debate pits Rudin, INS official. The Sacramento Bee, p. B3.

Chávez, E. (2000, August 23). New drive for amnesty unites local immigrants. The Sacramento Bee, p. A1. 
Chávez, K. (1993, October 5). Wilson signs laws to staunch undocumented immigration. The Sacramento Bee, p. A4.

Chávez. K. R. (2011). Counter-public enclaves and understanding the rhetoric in social movement coalition-building. Communication Quarterly, 59(1), 1-18.

Chernotsky, H. \& Hobbs, H. (2001). Responding to globalization: State and local initiatives in the Southeastern United States. Passages, 3(1), 57-82.

Chishti, M. (2002). The role of States in U.S. immigration policy. New York University Annual Survey of American Law, 58, 371-76.

Christensen, K. (2000, September 7). INS team scrutinizing Portland office. The Oregonian. Retrieved from http://www.oregonlive.com.

Christensen, K., Read, R., Sullivan, J. \& Walth, B. (2000, December 10). Unchecked power of the INS shatters American Dream. The Oregonian. Retrieved from http://www.oregonlive.com.

Chronis, P. (1994a, November 30). INS agents nail 33 working as roofers. The Denver Post, p. B4.

. (1994b, August 26). INS raids 2 Denver companies, nabs 61 undocumented workers. The Denver Post, p. B7.

Chuang, A. \& Haught, N. (2007, June 15). Raid makes debate over sanctuary real. The Oregonian, p. A1. . (2007, June 16). Sanctuary: A history rooted in the Bible. The Oregonian, p. A1.

Chung, L. (1993, June 22). State's Asians stung by immigration backlash. The San Francisco Chronicle, p. A7.

Church, F. (1994, November 22). Oregon unlikely to feel effects of Proposition 187. The Oregonian, p. B3.

City approves use of ID cards for Mexican, Guatemalan nationals. (2005, April 13). Dayton Business Journal. Retrieved from http://www.bizjournals.com/dayton.

Citizens' Commission on Central America Records, 1983-1986. (2008). Seattle, WA: Author. Retrieved from http://www.seattle.gov/cityarchives.

Cities discovering an Arizona boycott may do more harm. (2010, June 28). Fox News Network. Retrieved from http://www.foxnews.com. 
Cities/counties boycotting Arizona. (2010, June 8). NumbersUSA. Retrieved from http://www.numbersusa.com.

City won't aid immigration officers. (2007, April 24). The New York Times. Retrieved from http://www.nytimes.com.

Civic Task Force on International Cleveland. (2003, December). Civic Task Force on International Cleveland: Recommendations to the City of Cleveland. Retrieved from http://www.city.cleveland.oh.gov.

Clark, J. (2001). Six urban regime types. Public Administration Quarterly, 25(1), 3-48.

Clark, R., \& Anderson, S. (2000, June 30). Illegal aliens in federal, state, and local criminal justice systems. Washington, DC: The Urban Institute. Retrieved from http://www.urban.org.

Coakely, T. (1987, Sept. 22). Drive against INS western chief. The Sacramento Bee, p. A12.

Coates, J. (1985, December 29). In a new sanctuary debate, fine line divides criminal, refugee. Chicago Tribune. Retrieved from http://nl.newsbank.com.

Cochrane, C. (1999). Redefining urban politics for the twenty-first century. In Andrew E. G. Jonas \& David Wilson (Eds.), The urban growth machine. New York, NY: State University of New York Press.

Coffield, D., \& Hudson, K. (2005, May 12). Officials: Verifying suspect's immigration status wasn't vital. The Denver Post, p. A14.

Cohen, N. (2012, July). Policy entrepreneurs and the design of public policy. Journal of Social Science Research and Policy, 3(1), 5-26.

Coleman, M. (2007). Immigration geopolitics beyond the Mexico-U.S. border. Antipode $39,54-76$.

. (2012). The 'local' migration state: The site-specific devolution of immigration enforcement in the U.S. South. Law \& Policy, 34(2), 159-190.

Colorado Alliance for Immigration Reform [CAIRCO]. (2005a). Press conference and protest of Denver sanctuary policy. Retrieved from http://www.cairco.org.

. (2005b) Libraries and Spanish language materials at taxpayer expense. Retrieved from http://www.cairco.org. 
.(2005-2006). Denver's El Centro hiring hall for illegal aliens. Retrieved from http://www.cairco.org.

. (n.d.). Background-Mexican matricular consular (illegal alien) ID card in Colorado. Retrieved from http://www.cairco.org.

Colorado Immigrant Rights Coalition (CIRC). (2010, May 10). CIRC applauds Denver City Council proclamation in support of comprehensive immigration reform in 2010 [Press release]. Retrieved from http://coloradoimmigrant.org.

. (n.d.) Show Me Your Papers: Arizona's SB1070 and Colorado's SB90. Retrieved from https://afl.salsalabs.com.

Colorado lawmakers pass strict illegal immigration laws. (2006, July 11). Associated Press on Fox News Network. Retrieved from http://www.foxnews.com.

Community Resource Project Inc. (n.d.). $41^{\text {st }}$ Ave. Community Center. Retrieved from http://www.cresource.org.

Conservatives vs. liberal beliefs. (2010). Student Daily News. Retrieved from http://www.studentnewsdaily.com.

Contreras, R. (2010, May 3). Boston officials want city to boycott Arizona. Associated Press. Retrieved from http://www.azcentral.com.

Conway, M. (1999, June-July). The great cities of the future. The Futurist, 33(6), 28-32.

Cooke, S. (2002, March 19). Denver approves civil liberties resolution. Associated Press. Retrieved from http://nl.newsbank.com.

Cornelius, W. (1998). The structural embeddedness of demand for Mexican immigrant labor: New evidence from California. In M. M. Suárez-Orozco (Ed.). Crossings: Mexican immigration in interdisciplinary perspective (pp. 113-44), Cambridge, MA: Harvard University, David Rockefeller Center Series on Latin American Studies.

Coronado, R. (1993, March 6). Help INS or lose millions in federal funds, state's jails told. The Sacramento Bee, p. B1.

Couch, M. P. (2006, April 13). Proposed 'sanctuary city' ban gets albatross amendment. The Denver Post, p. B2.

Council should vote to protect wages [Editorial]. (2005, November 25). The Denver Post, p. B7. 
Covarrubias, A. (1994, November 17). Proposition 187 triggers boycott threats. Associated Press. Retrieved from http://nl.newsbank.com.

Craig, T. (2012, February 19). D.C. won't cooperate with federal immigration enforcement. The Washington Post. Retrieved from http://www.washingtonpost.com.

Crummy, K. (2005a, May 19). Mayor defends foreigner policy. The Denver Post, p. A1. . (2005b, May 31). A reluctant enforcer: City cites fiscal, social costs of policing immigrants. The Denver Post, p. A1.

. (2005c, June 23). DeGette tells Tancredo: Leave Denver alone. The Denver Post, p. A1.

. (2005d, July 18). Workers' status is complex business. The Denver Post, p. A1.

. (2005e, August 9). Library protest becomes rift over immigration. The Denver Post, p. B2.

. (2005f, August 24). Fotonovela subscriptions ended. The Denver Post, p. A1.

. (2006a, January 8). Immigration dispute flares at center. The Denver Post, p. C1.

. (2006b, January 18). Ex-councilor quits Holtzman's camp. The Denver Post, p. B2.

. (2010, April 29). Candidates' dividing line GOP contenders back Arizona law. The Denver Post, p. A1.

Dallas suburb passes landmark anti-illegal laws. (2006, November 16). Associated Press on Fox News Network. Retrieved from http://www.foxnews.com.

Daniels, R. (2004). Guarding the golden door: American immigration policy and immigrants since 1882. New York, NY: Hill and Wang.

Danielson, M. S. (2010). All immigration politics is local: The day labor ordinance in Vista, California. In Monica W. Varsanyi (Ed.), Taking local control (pp. 239254). Stanford, CA: Stanford University Press.

Datel, R, \& Dingemans, D. (2008). Immigrant space and place in suburban Sacramento. In A. Singer, S. Hardwich \& C. Brettell, (Eds.), Twenty-first century gateways (pp. 171-199). Washington, DC: Brookings Institute Press. 
Davies, J. (2003). Partnership verses regimes: Why regime theory cannot explain urban coalitions in the UK. Journal of Urban Affairs, 25(2), 253-269.

Davila, R. D. (1994, October 28). Officials draw activists cheers quizzed on jobs, housing. The Sacramento Bee, p. B1.

. (2002, April 14). New ID cards open doors for Mexican citizens. The Sacramento Bee, p. B3.

. (2003, Feb. 4). Homeland defense may find home in the capital. The Sacramento Bee, p. B1.

Davis, M. (2006, September 26). Burning cross will accomplish nothing. Lexington Herald Leader, p. D1.

Davis, M., \& Ruiz, A. (2007, April 26). Labor pains. Portland Mercury. Retrieved from http://www.portlandmercury.com.

Day labor center protestor convicted, fined \$500. (2008, April 18). Portland KATU-TV. Retrieved from http://www.katu.com.

Day labor site opens in northeast Portland. (2008, June 16). Portland KATU-TV. Retrieved from http://www.katu.com.

Day Labor Research Institute. (2004). Comparing solutions: An overview of day labor Programs. Portland, OR: Author. Retrieved from http://daylaborinfo.org.

Day-laborers skirt law in growing underground economy. (2006, November 26). Sacramento Business Journal. Retrieved from http://www.bizjournals.com/sacramento.

Daza, R. (2002a, April 5). Helping people without papers. The Oregonian, p. C1. . (2002b, September 13). INS role for police stirs up concerns. The Oregonian, p. C1.

De Yoanna, M. (2002, May 2). Colorado immigrant enforcement bill passes. University Wire. Retrieved from http://nlnewsbank.com.

DeLeon, R. E. 1992. The urban antiregime: Progressive politics in San Francisco. Urban Affairs Quarterly 27, 555-79. 
Della Porta, D. (2002). Comparative politics and social movements. In B. Klandermans \& S. Staggenborg (Eds.), Methods of social movement research (pp. 286-313). Minneapolis, MN: University of Minnesota Press.

Delson, J. (April 6, 2001). Costa Mesa chief retires amid tumult. The Los Angeles Times, p. B1.

Denson, B. (2007, June 29). Reds indict 10 workers detained in Portland raid. The Oregonian, p. C2.

Denson, B. \& Hunsberger, B. (2007, June 13). Immigration raid pushes Oregon into thick of fight. The Oregonian, pp. A1, A8.

Denver mayor opposes deportation of immigrant student. (2002, October 3). The Associated Press. Retrieved from http://nl.newsbank.com.

Denver Office of Community Support. (n.d.). Immigration and refugees: Immigration integration [Web page]. Retrieved from http://www.denvergov.org.

Denver Police Department. Police Operations Manual, 90-100. Retrieved from http://www.denvergov.org.

Denver repeals ordinance targeting undocumented drivers. (2011, July 12). Fox News Latino. Retrieved from http://www.foxnews.com.

Diaz, E. (1996, July 22). Immigrants wait for a day's job. The Oregonian, p. B1.

Dinan, K (2005). Children in low income immigrant families policy brief. New York, NY: National Center for Children in Poverty. Retrieved from http://www.nccp.org.

Dinerstein, M. (2003). IDs for illegals: The 'matricular consular' advances Mexico's immigration agenda [Backgrounder]. Washington, DC: Center for Immigration Studies. Retrieve from http://www.cis.org.

Domhoff, F.W. (2002, October). Power in America: The shortcomings of rival urban theories. Retrieved from http://www2.ucsc.edu/whorulesamerica/power/rival_urban_theories.html.

Draper, E. (2008, July 29). Group battles measure to impound cars. The Denver Post, p. B1. 
Drennen, K. (2009, June 15). CBS: Immigration raid left Iowa town's economy 'in tatters'[Blog]. Media Research Center. Retrieved from http://newsbusters.org/blogs/kyle-drennen.

Duran, L. \& Flores, E. (1998, Nov. 29). Immigration raids shatter families. The Denver Post, p. G3.

Dworkin, A. (2008, January 10). Sum of departures bigger than the parts. The Oregonian, inPortland, p. 3.

Eifertsen, T. (1996, January 26). As aid cuts loom, urban leaders unite. The Sacramento Bee, p. N1.

Edwards, C., Jones, G., Lawton, A., \& Llewellyn, N. (2002). Public entrepreneurship: rhetoric, reality and context. International Journal of Public Administration, 25(12), 1539-1554.

Edwards, J. (2003, April). Officers need backup: The role of state and local police in immigration law enforcement [Backgrounder], 1-11. Washington, DC: Center for Immigration Studies. Retrieved from http://www.cis.org.

Eisenhardt, K. 1989. Building theories from case study research. Academy of Management Review, 14(4), 532-50.

Eltman, F. (2010, November 22). Hate crime victim's estate sues New York authorities. Fox News. Retrieved from http://foxnews.com.

Esbenshade, J. (2007). Division and dislocation: Regulating immigration through local housing ordinances [Special Report], 1-20. Washington, DC: Immigration Policy Center.

Esbenshade, J., Wright, B., Cortopassi, P., Reed, A., \& Flores, J. (2010). The 'law-andorder' foundation of local ordinances. In Monica W. Varsanyi (Ed.), Taking local control (pp. 255-274). Stanford, CA: Stanford University Press.

Esmeralda, B. (2007, December 12). Bracelet women scrape by. The Oregonian, p. C1.

Espenshade, T., \& Huber, G. (1999). Fiscal impacts of immigrants and the shrinking welfare state. In C. Hirschman, P. Kasinitz, \& J. DeWind (Eds.), The handbook of international migration (pp. 360-370). New York, NY: Russell Sage Foundation.

Espinoza, A. (2005, October 23). Migrant forum tips emotion Tancredo applauds call for reform. The Denver Post, p. C2. 
Espinoza, A. \& McWilliams, H. (2010, May 2). Thousands march through Denver to protest Arizona immigration law. The Denver Post. Retrieved from http://www.denverpost.com.

Espinoza, S. (1992, April 30). Caring for undocumented kids. The San Francisco Chronicle, p. A1.

Esquivel, A. (2008). Let freedom ring: A collection of documents from the movements to free U.S. political prisoners. M. Meyer (Ed.) Oakland, CA: PM Press.

Eyck, T. (2008, July 28). Uneasy reception for Portland day labor center. Labor Notes. Retrieved from http://labornotes.org.

Fair Immigration Reform Movement [FIRM] (2007, July 23). Database of recent local ordinances on immigration. Washington, DC: Center for Community Change. Retrieved from http://www.fairimmigration.org.

Farley, J. (2010). Majority-minority relations (6 ${ }^{\text {th }}$ ed.). San Francisco, CA: Prentice Hall.

Federal Bureau of Investigation. (n.d.). Denver Division: A brief history. Retrieved from http://www.fbi.gov/denver.

Federal Bureau of Investigation. (n.d.). Sacramento Division: A brief history. Retrieved from http://www.fbi.gov/sacramento.

Federation for American Immigration Reform [FAIR]. (2003). Immigration issues: 'Sanctuary' policies. Retrieved from http://www.fairus.org.

Fehr, E. (2010, June 16). Sacramento to sanction Arizona. Sacramento Examiner. Retrieved from http://www.examiner.com/sacramento.

Feere, J. (2007). Curbing day laborers: Anti-solicitation ordinances, commercial speech, and hiring centers [Unpublished paper]. American University, Washington College of Law. Retrieved from http://works.bepress.com/jon_feere/1.

Fennelly, K, \& Orfield, M. (2008). Impediments to the integration of immigrants: A case study in the Twin Cities. In A. Singer, S. Hardwick, \& C. Brettell (Eds.), Twentyfirst century gateways (pp. 200-224). Washington, DC: Brookings Institute Press.

Ferriss, S. (2006a, March 11). Rally fights border measure. The Sacramento Bee, p. B3. . (2006b, May 2). 1 million protest. The Sacramento Bee, p. A1. 
. (2007, July 26). Day labor centers try to take workers off street corners. The Sacramento Bee, p. A3.

. (2008, May 1). Fargo tribute hails immigrant workers. The Sacramento Bee, p. B2.

Ferriss, S. \& Magangnini, S. (2009, October 22). Sacramento police chief says legalize undocumented immigrants. The Sacramento Bee. Retrieved from http://www.sacbee.com.

Fikes, B. (2010. May 24). San Diego didn't boycott Arizona [Blog]. North County Times. Retrieved from http://www.nctimes.com.

Finley, B. (1995, May 27). Envoy: Austerity to boost Mexico tough steps needed, Denverites told. The Denver Post, p. A3.

. (1998, March 8). City welcomes immigrants: Mayor backs \$1 million plan to provide extended services. The Denver Post, p. B1.

. (2005a, July 10). The new baby boom: Immigrants. The Denver Post, p. A1.

. (2005b, December 22). Hiring-rules enforcement nonexistent. The Denver Post, p. A1.

Fix, M. \& Passel, J. (2002). The scope and impact of welfare reform's immigrant provisions. Washington, DC: The Urban Institute. Retrieved from http://www.brookings.edu.

Flacke, T. \& Wertheim, T. (2006, May). Delivering a local EITC. Washington, DC: The Brookings Institute Metropolitan Policy Program. Retrieved from http://www.brookings.edu.

Fletcher, M.A. (2000, August 30). Senators seek removal of Oregon INS official. The Washington Post, p. A23.

Fleury-Steiner, B. \& Longazel, J. (2010). Neoliberalism, community development, and anti-immigrant backlash in Hazelton, Pennsylvania. In Monica W. Varsany (Ed.), Taking local control (pp. 157-172). Stanford, CA: Stanford University Press.

Fox, B. (2005, November 27). City arrests, fines day laborers. Long Beach PressTelegram, p. A22.

Frank, R. (2002, September 14). Officials object to police agencies assuming new role. The Oregonian, p. B2. 
. (2005, March 24). FBI rules out Potter demand on terror force. The Oregonian. Retrieved from http://www.freerepublic.com.

. (2010a, June 14). Portland City Council to oppose Arizona immigration law but stop short of boycott. The Oregonian. Retrieved from http://www.oregonlive.com.

. (2010b, November 29). City Hall: A look back on Mayor Tom Potter's decision to pull Portland out of FBI-led Joint Terrorism Task Force. The Oregonian. Retrieved from http://www.oregonlive.com.

Fretzer, J. S. (2000). Public attitudes towards immigration in the United States, France and Germany. New York, NY: Cambridge.

Frey, W. (2006, March 24). Immigration policy: Federal debates and local realities. [U. S. Capital Building Briefing], March 24, 2006. Washington, DC: The Brookings Institution Metropolitan Policy Program.

. (2011, October 28). Young adults choose "cool cities" during recession. Brookings Up Front [Blog]. Retrieved from http://www.brookings.edu.

Frey, W., \& Muro, M. (2008, August 25). Painting the mountain states blue. Retrieved from http://www.brookings.edu.

Friedmann, J., \& Lehrer, U. (1997). Urban policy responses to foreign in-migration. Journal of the American Planning Association, 63(1), 61-78.

Freilich, T. (June 9, 2003). Learning from Farmingville: Promising practices for immigrant workers [Forum transcript]. Washington, DC: The Brooking Institute Center for Urban and Metropolitan Policy. Retrieved from http://www.brookings.edu .

Friesen, S. (2009, June 18). Portland's day labor center celebrates one-year anniversary. The Oregonian. Retrieved from http://www.oregonlive.com.

Frisken, F., \& Wallace, M. (2002, May). The response of the municipal public service sector to the challenge of immigrant settlement. Report prepared for Citizenship and Immigration of Canada, Ontario Region, OASIS.

Furillo, A. (1993a, January 5). Fresno cop picked for chief's post. The Sacramento Bee, p. A1.

. (1993b, January 26). Capital's new police chief pledges 'partnership' role. The Sacramento Bee, p. A1. 
. (2002, December 26). Study cool to 'living wage.' The Sacramento Bee, p. B1.

Furrer, R. S. (2007, June 14). The Del Monte immigration raid [Letter to the editor]. The Oregonian, p. D11.

Furuseth, O., \& Smith, H. (2010). Localized immigration policy: The view from Charlotte, North Carolina, a new immigration gateway. In Monica W. Varsanyi (Ed.), Taking local control (pp. 173-192). Stanford, CA: Stanford University Press.

Gallup cuts business ties with Arizona. (2010, May1). KRQE-TV News. Retrieved from http://www.krqe.com.

Garber, J. (2005). The construction of the geography of immigration as a policy problem. Urban Affairs Review, 40(4), 520-561.

Garcia, A. (2010, May 4). City of El Paso condemns Arizona, calls for a boycott. KTSMTV News. Retrieved from http://www.ktsm.com.

Gartner, E. (2005, September 4). Libraries beefing up Spanish-oriented material, sometimes drawing criticism. The Associated Press. Retrieved from http://nl.newsbank.com.

Gibbs, N. (2005, April 17). The 5 best big-city mayors in America. Time Magazine. Retrieved from http://www.time.com.

Gibson, K., \& Abbott, C. (2002). City profile: Portland, Oregon. Cities 19(6), 425-436.

Gimpel, J. \& Edwards, J., Jr. (1999). The congressional politics of immigration reform. Needham Heights, MA: Allyn \& Bacon.

Girdner, B. (1986, January 3). Sanctuary movement angers INS cities protect Latin refugees. The Miami Herald, p. A1.

Glaser, B. \& Strauss, A. (1967). The discovery of grounded theory. Hawthorne, NY: Aldine.

Golden, R. \& McConnell, M. (1986). Sanctuary: The new underground railroad. Maryknoll, NY: Orbis Books.

Good, K. (2005). Patterns of politics in Canada's immigrant-receiving cities and suburbs. Policy Studies 26(3/4), 261-289. 
Goodwin, J. \& Jasper, J. (2004). The social movement reader: Cases and concepts. Malden, MA: Blackwell Publishing.

Gonzalez, A. (2007, July). Day labor in the golden state. California Economic Policy, 2(3), 1-21. San Francisco, CA: Public Policy Institute of California.

Gonzalez, C. (1998, February 2). Job-seekers come in from the cold. The Oregonian, p. E1.

Goranson, E. (1989, March 2). Farmers express concern over getting enough workers. The Oregonian, p. B6.

Gorman, A. (2008a, April 10). Mayor chides ICE for workplace raids. The Los Angeles Times. Retrieved from http:/www.latimes.com. . (2008b, June 8). U.S.-born children feel effects of immigration raids. The Los Angeles Times. Retrieved from http://www.latimes.com.

. (2005, August 29). Day laborers, cities seek a way that will work. The Los Angeles Times. Retrieved from http://www.latimes.com.

Gottlieb, A. (1990, February 11). Cultures clash as Hispanics settle on West Slope. The Denver Post. Retrieved from http://nl.newsbank.com.

Gozdziak, E., \& Martin, S. (2005). Beyond the gateway: Immigrants in a changing America. New York, NY: Lexington Books.

Graves, R. \& Rios, C. (2001, April 16). Labor-intensive care. The Houston Chronicle, p. A1.

Greater Sacramento Area Hate Crimes Task Force. (n.d.). Description. The U.S. Attorney's Office, Eastern District of California. Retrieved from http://www.justice.gov.

Green, A. (2008, July29). Critic of day-labor center sues city officials. The Oregonian, p. D2.

Green, A. \& Bernstein, M. (2001, December 2). Controversy swirls around 2 state laws. The Oregonian, p. A1.

Green, S. (2005, May 19). ACLU: Pull cops from terror unit. The Denver Post, p. B2.

Greenhouse, S. (2005, Oct. 10). Front line in day laborer battle runs right outside Home Depot. The New York Times, p. A1. 
Grenoble, R. (2011, July 12). Denver City Council repeals Initiative 100, impound law targeting illegal immigrants. The Huffington Post. Retrieved from http://www.huffingtonpost.com.

Griffin, A. (2005, April 25). Joy in the gallery as Portland quits FBI task force. The Oregonian. Retrieved from http://news.infoshop.org.

. (2007a, June 14). 1992 raid toughened Potter's stance. The Oregonian, p. A10.

. (2007b, July 29). Where to put day laborers. The Oregonian, p. C1.

. (2008a, June 7). Obama victory about more than politics in Portland. The Oregonian, p. A4.

. (2008b, June 13). Center for day laborers opens in Portland [Blog]. The

Oregonian. Retrieved from http://blog.oregonlive.com.

. (2008c, June 17). Day labor center opens, but few jobs to be had. The Oregonian, pp. A1, A7.

Griffith, D. (1996a, January 4). Welfare Summit is planned. The Sacramento Bee, p. B1. . (1996b, January 26). As aid cuts loom, urban leaders unite. The Sacramento Bee, p. B1.

Guerette, R. (2007, October). Disorder at day laborer sites: Guide No. 44. Washington, DC: Center for Problem-Oriented Policing. Retrieved from http://www.popcenter.org.

Gupta, C. (2005, Summer). International Cleveland. ColorLines, 44-47.

Gutierrez, H. (2002, May 15). Day workers get center in Curtis Park. Rocky Mountain News, p. 14A.

Guevarra, L. \& Farrell, D. (1985, December 24). Supervisors declare S.F. a refugee sanctuary. The San Francisco Chronicle. Retrieved from http://nl.newsbank.com.

Haley, K. (2010a, May 26). City council to consider economic boycott against Arizona. The Sacramento Press. Retrieved from http://www.scarmentopress.com.

. (2010b, June 15). City leaders approve Arizona boycott. The Sacramento Press. Retrieved from http://www.scarmentopress.com. 
Hempel, C. (1965). Aspects of scientific explanation and other essays in the philosophy of science, New York, NY: Free Press.

Hanely, L., Ruble, B., \& Garland, A. (Eds.) (2008). Immigration and integration in urban communities. Washington, DC: Woodrow Wilson Center Press.

Hannah-Jones, N. (2011, May 1). In Portland's heart, diversity dwindles. The Oregonian, p. A1.

Hansen, A. (2005). Black and White and the Other: International immigration and change in metropolitan Atlanta. In Gozdziak, E., \& Martin, S. (Eds.), Beyond the gateway: Immigrants in a changing America (pp. 87-110). New York, NY: Lexington Books.

Har, J. (2006, September 2). New front in illegal immigration fight. The Oregonian, p. A1.

. (2010, June 16). Portland City Council calls Arizona immigration law un-American. The Oregonian. Retrieved from http://www.oregonlive.com.

Hardwick, S., \& Meacham, J. (2008). Placing the refugee diaspora in suburban Portland, Oregon. In A. Singer, S. Hardwich \& C. Brettell, (Eds.), Twenty-first century gateways (pp. 225-256). Washington, DC: Brookings Institute Press.

Harwood, S., \& Myers, D. (2002). The dynamics of immigration and local governance in Santa Ana: Neighborhood activism, overcrowding, and land-use policy. Policy Studies Journal, 30(1), 70-91.

Harrington, M. (1994, November 11). Coalition protests 'racist' measure: Coloradans outraged by Calif. Proposition. The Denver Post, p. B1.

Harris, P. (2012, February 11). Portland, the US capital of alternative cool, takes TV parody in good humour. The Gauardian News. Retrieved from http://www.guardian.com.

Harris, S. (Oct 30, 2005). Hardship city. The Los Angeles Times, p. I18.

Harsanyi, D. (2005, May 16). Why turn a blind eye to illegals? The Denver Post, p. B1.

Hart, M., Stevenson, H. \& Dial, J. (1995). Entrepreneurship: A definition revisited. Frontiers of Entrepreneurship Research, 89-95. Wellesley, MA: Babson College.

Harvard Law Review. (2005). The Constitutionality of immigration federalism. Developments in the Law: Jobs and Borders, 118: 1-24. 
Harwood, S., \& Myers, D. (2002). The dynamics of immigration and local governance in Santa Ana. Policy Studies Journal, 30(1), 70-92.

Haught, N. (2007a, September 14). Portland supporters of the New Sanctuary movement. The Oregonian, p. C1.

. (2007b, September 22). Churches weigh offering help to illegal immigrants. The Washington Post. Retrieved from http://www.washingtonpost.com.

. (2010, December 17). Supporters gather for posada and 'just and humane' immigration reform, The Oregonian. Retrieved from http://www.oregonlive.com.

Hayduk, R. (2003). Noncitizen voting rights. National Civic Review, 92(4), 57-62.

. (2006). Democracy for all: Restoring immigrant voting rights in the United States. New York, NY: Routledge.

. (2009). Radical responses to neoliberalism: Immigrants rights in the global era. Dialectical Anthropology, 33(2), 157-173.

Hayward, B. (1994a, September 20). Debate on immigration reform crackles with passion, outrage. The Sacramento Bee, p. A1.

. (1994b, November 3). Better solution than Prop. 187, Reich says. The Sacramento Bee, p. A6.

Healey, J. F. (2004). Diversity and society: Race, ethnicity, and gender. Thousand Oaks, CA: Pine Forge Press.

Hellegers, D. (2005, June 24). Civic resistance to the Bush Administration's culture of fear and secrecy: Portland versus the FBI. Counter Punch. Retrieved from http://www.counterpunch.org.

Hellegers, D. \& Mercier, L. (2002, October 31). Red squads redux: Portland activists mobilize against the FBI's Joint Terrorism Task Force. Counter Punch. Retrieved from http://www.counterpunch.org.

Henig, J., Hula, R., Orr, M., \& Pedescleaux, D. (1999). The color of school reform: Race, politics, and the challenge of urban education. Princeton, NJ: Princeton University Press.

Heredia, C. (2007, May 15). Oakland City Council condemns federal immigration raids. The San Francisco Chronicle. Retrieved from http://www.sfgate.com. 
Hernández, D. (July/August 2006). Roundups: Watching the war on terror. Colorlines, 12.

Hernández-León, R. and Zúñiga, V. (2002). Mexican immigrant communities in the South and social capital [Working paper No. 64]. University of California-San Diego: Centre for Comparative Immigration Studies.

Herndon closed day labor center. (2007, September 14). Associated Press in the Culpeper Star Exponent. Retrieved from http://www.startexponent.com.

Hero, R. (1989). Multiracial coalitions in city elections involving minority candidates: Some evidence from Denver. Urban Affairs Review, 25(2), 342-351.

. (1989, June). The elections of Frederico Peña as Mayor of Denver. Social Science Quarterly, 70(2), 300-310.

. (1992). Latinos and the U.S. political system: Two-tiered pluralism. Philadelphia, PA: Temple University Press.

. (1998). Faces of inequality. New York, NY: Oxford University Press.

. (2003). Multiple theoretical traditions in American politics and racial policy inequality. Political Research Quarterly, 56(4), 401-408.

Hero, R. \& Fitzpatrick, J. (1989). State mandating of local government activities. Policy Studies Journal, 17(4), 745-759.

Hero, R., \& Tolbert, C. (1996). A racial/ethnic diversity interpretation of politics and policy in the states of the U.S. American Journal of Political Science, 40(2), 85171.

Hethmon, M. (2004). The Chimera and the Cop: Local enforcement of federal immigration law. University of District of Columbia Law Review, 8, 83-140.

Heye, B. (2008, August 20). City plowing more money into day labor site. KATU-TV. Retrieved from http://www.katu.com.

Hicks, L. (1995, Jan. 25). Serena to attend welfare session at White House. The Sacramento Bee, p. B1.

Hill, L., \& Johnson, H. (2011, July). Unauthorized immigrants in California. San Francisco, CA: Public Policy Institute of California. 
Hincapié, M., \& Tumlin, K. (2008, June 19). The Los Angeles Raid Response Network. Washington, DC: National Immigration Law Center. Retrieved from http://v2011.nilc.org.

Hispanic American Police Command Officers Association (n.d.). About HAPCOA. Retrieved from http://www.hapcoa.org.

Hobbs, H. (1994). City hall goes abroad: The foreign policy of local politics. Thousand Oaks, CA: Sage Publications. . (2004). Fragmenting federalism and the reinvigoration of local foreign policy activism. Paper presented at the $45^{\text {th }}$ Annual International Studies Association Convention, Montreal, Quebec, March 17-20, 2004.

Hoefer, M., Rytina, N. \& Backer, B. (2011, February). Estimates of the unauthorized immigrant population residing in the United States: January 2010. Washington, DC: Department of Homeland Security Office of Immigration Statistics. Retrieved at http://www.dhs.gov/xlibrary/assets/statistics/publications/ois_ill_pe_2010.pdf

Home away from home for Ukrainians, Fijians. (2006, November 26). Sacramento Business Journal. Retrieved from http://www.bizjournals.com/sacramento.

Home Depot Amendment [Editorial]. (2007, June 22). The New York Times. Retrieved from http://www.nytimes.com.

Hoover, E. (1994, April 16). Police launch second sweep for drug dealers. The Oregonian, p. D1.

Hoover, T. (2009, January 7). Immigration panel urges leverage for cops. The Denver Post, p. B1.

Hortsch, D. (1998, March 25). Angry workers group condemns INS raid tactics. The Oregonian, p. E2.

Hsu, S. (2008, May 18). Immigration raid jars a small town: Critics say employers should be targeted. The Washington Post, p. A1.

Hubbard, B. (2008, Sept. 10). Tragedy may spur legislation. Rocky Mountain News. Retrieved from http://www.rockymountiannews.com.

Hudson, A. (2003, June 14). Mexico's ID cards gain more acceptance in states, cities. The Washington Times, p. A1. 
Hudson, K. (2005, May 13). 'Sanctuary' policy sparks radio fracas. The Denver Post, p. A18.

Huitema, D., \& Meijerink, S. (2010). Realizing water transitions: The role of policy entrepreneurs in water policy change. Ecology and Society, 15(2), 26 [online]. Retrieved from http://www.ecologyandsociety.org.

Hunsberger, B. (2006, June 25). Crackdown coming on bogus papers. The Oregonian, p. E1.

Huntington, C. (2008). The Constitutional dimensions of immigration federalism. Vanderbilt Law Review, 61, 787-853.

Illegals as trespassers [Editorial]. (June 13, 2005). The Washington DC Times, p. A18.

Illinois mayors are frustrated waiting for 287(g) training [Blog]. (2008, May 28).

Retrieved from http://bordercontrol.blogspot.com.

Immigration law: Local police must tread carefully [Editorial]. (2004, May 25). The Sacramento Bee, p. B6.

Immigrant mayors. (1999, November 8). The San Francisco Chronicle, p. A3.

Immigration Policy Center. (2010, October). Giving facts a fight chance: Answers to tough immigration questions. Washington, DC: Author. Retrieved from http://www.immigrationpolicy.org. . (2008, June 20). Leading mayors decry raids [Press release].Washington, DC: Author. Retrieved from http://www.immigrationpolicy.org.

Ingold, J. (2005, May 27). 'They have to hear us': Community activist visit Washington, D.C., to improve life in Denver. The Denver Post, p. B2.

Internal Revenue Service. States and Local Governments with Earned Income Tax Credits. Washington, DC: U.S. Government Printing Office. Retrieved from http://www.irs.gov.

International imports. (2007, July 22). Sacramento Business Journal. Retrieved from http://www.bizjournals.com/sacramento.

Jacklet, B. (2000, August 9). Down on the corner. Willamette Week. Retrieved from http://www.wweek.com. 
Jansen, J. (2006, July 11). Colorado legislature passes bill requiring proof of citizenship for public benefits. JURIST Legal News and Research. Retrieved from http://jurist.law.pitt.edu.

Jenkins-Smith, H., Silva, C., \& Waterman, R. (2005, August) Micro- and macro-level models of the presidential expectations gap. The Journal of Politics 67(3), 690715.

Ji, Minsun (director El Centro), email message to author, January 5, 2009.

Johansen, E. (2000, November 26). Where are the workers? Denver Business Journal. Retrieved from http://www.bizjournals.com/denver.

Johnson Jr., J., Farrell Jr., W., \& Guinn, C. (1999). Immigration reform and the browning of American. In C. Hirschman, P. Kasinitz, and J. DeWind (Eds.), The handbook of international migration (pp.390-411). New York, NY: Russell Sage Foundation.

Johnson, S. (2004). The myth and reality of Portland's engaged citizenry and processoriented government. In C. Ozawa (Ed.) The Portland edge. Washington, DC: Island Press.

Jones-Correa, M. (Ed.) (2001). Governing American cities: Inter-ethnic coalition, competition, and conflict. New York, NY: Russell Sage Foundation.

Jones, S. (2006, June 02). Anti-immigration billboards sprout in Denver. Cybercast News Service [CNS]. Retrieved from http://www.cnsnews.com.

Jordon, M. (2005, July 18). Immigrant workers are curbside attraction for activists. The Wall Street Journal. Retrieved from http://www.wallstreetjournal.com.

Joyce, P. D. (2001). Protest or violence: Political process and patterns in Black-Korean conflict. In M. Jones-Correa (Ed.), Governing American cities: Inter-ethnic coalition, competition, and conflict (pp. 158-180). New York, NY: Russell Sage Foundation.

Judge throws out illegal immigration lawsuit. (2005, December 14). KTVB-TV. Retrieved from http://www.ktvb.com.

Judicial Watch sues Herndon over aliens. (2005, September 1). The Washington Times. Retrieved from http://www.washingtontimes.com. 
Junta for Progressive Action, Inc. and Unidad Latina en Acción. (2005, October). A City to model: Six proposals for protecting public safety and improving relationships between immigrant communities and the City of New Haven. New Haven, CT: Author.

Kalhan, A. (2008). Immigration enforcement and federalism after September 11, 2001. In A. Chebel d'Appollonia \& S. Reich (Eds.), Immigration, integration, and security (pp. 181-202). Pittsburgh, PA: University of Pittsburg Press.

Kane, A. \& Lingle, C. (2001, November 29). Day laborers going unpaid: City seeks grants for help center. The Denver Post, p. B1.

Kelley, M. (2011, March 27). Local, state governments finding hefty costs behind implementing, defending illegal immigration measures. The Commercial Appeal. Retrieved from http://www.commercialappeal.com.

Khan, F. \& Sridhar, P. (2008, June 12). Immigration failure falls hard on suburban D.C. Medill News Service. Retrieved from: http://news.medill.northwestern.edu.

Kim, G. (2010, May 2). Protestors take on Arizona law. The Sacramento Bee, p. A1.

Keen, J. (2006, June 19). Big cities reluctant to target immigrants. USA Today. Retrieved from http://www.usatoday.com.

Kelley, D., Yi, D., \& Becerra, H. (2001, June 10). Crowding now way of life in California. The Los Angeles Times. Retrieved from http://www.latimes.com.

Kennedy, R. (2009, April 5). Texas mayor caught in deportation furor. The New York Times. Retrieved from http://www.nytimes.com.

Keogan, K. (2002). A sense of place: The politics of immigration and the symbolic construction of identity in Southern California and the New York Area. Sociological Forum, 17(2), 223-253.

Kilgannon, C. (2007, March 1). Suffolk plans a crackdown on laborers there illegally. The New York Times. Retrieved from http://www.nytimes.com.

Kilzer, L. (2005a, May 19). Jailer pokes hole in city's claim. Rocky Mountain News. Retrieved from http://www.rockymountainnews.com. . (2005b, May 20). Feds check city jail list. Rocky Mountain News. Retrieved from http://www.rockymountainnews.com. 
Kim, M. (2006a, January 7). Groups protest at immigrant day-laborer site. Rocky Mountain News. Retrieved from http://www.rockymountainnews.com.

. (2006b, January 16). 'Invasion target' Protestors say center for day labor fosters illegal immigration. Rocky Mountain News. Retrieved from http://www.rockymountainnews.com. . (2006c, June 2). Denver officials deny city has a so-called 'sanctuary' policy. Rocky Mountain News. Retrieved from http://www.rockymountainnews.com. . (2006d, June 6). Peña group inks touted P.R. firm. Rocky Mountain News. Retrieved from http://www.rockymountainnews.com.

Kinder, D., \& Mendelberg, T. (2005, May). Cracks in American apartheid. Journal of Politics, 57(2), 402-424.

Kingdon, J. (1997). Agendas, alternatives, and public policy, ( $2^{\text {nd }}$ ed.). New York, NY: Harper Collins Publishers.

Klass, G. (2010, June 21). New website urges boycott of Sacramento city businesses. Boycott Sacramento. Retrieved from http://www.boycottsacramento.com.

Knight, Al. (2002, April 7). Anti-cop hysteria. The Denver Post, p. E5. . (2005, May 18). Cop killings merit the extra attention. The Denver Post, p. B7.

Kobach, K. (2005-2006). The quintessential force multiplier: The inherent authority of local police to make immigration arrests. Albany Law Review, 69, 179-235.

Kohut, A., Suro, R., Keeter, S., Doherty, C. \& Escobar, G. (2006, March 30). No consensus on immigration problem or proposed fixes. Washington, DC: Pew Research Center for the People \& the Press/Pew Hispanic Center.

Kollars, D. (1992, November 25). A call for unity Serna throws party for Capital. The Sacramento Bee, pA1.

Korber, D. (2001, December 18). Mexican Consulate deluged by ID requests since Sept. 1. The Sacramento Bee, p. B1.

. (2006, May 7). A major Latino movement, or one time event? The Sacramento Bee, p. B1.

Korosec, T. (2006, November 13). Dallas suburb cracks down on illegal immigration. The Houston Chronicle. Retrieved from http://www.chron.com. 
Kraus, N. (2004). The significance of race in urban politics: The limitations of regime theory. Race \& Society, 7, 95-111.

Kreck, D. (2006, May 9). Boyles wants listeners to boycott Denver newspapers. The Denver Post, p. F9.

Kresl, P., \& Fry, E. (2005). The urban response to internationalization. Northampton, MA: Edward Elgar Publishing, Inc.

Kretsedemas, P. (2008). What does an undocumented immigrant look like? In D. Brotherton \& P. Kretsedemas (Eds.), Keeping out the other (pp. 334-64). New York, NY: Columbia University Press.

Kroft, S. (2010, April 10). Welcome to Hazleton. CBS News. Retrieved from http://www.cbsnews.com.

Laborers can gather in public for jobs, federal judge rules. (2006, May 3). Associated Press. Retrieved from http://www.firstamenmentcenter.org.

Lam, M. (2002, October 8). Berkeley connects with sister cities across the globe. The Daily Californian. Retrieved from http://www.DailyCal.org.

Lambert, B. (2006, August 17). Congressman endorses Suffolk County plan to bar contractors from using illegal immigrants. The New York Times. Retrieved from http://www.nytimes.com.

Lammers, J. (2010, February 19). Matricular ID cards at issue again. The News Herald. Retrieved from http://www.news-herald.com/articles.

LaMountain, R. (2010, June 25). Support Arizona-boycott Portland [Blog]. The Oregonian. Retrieved from http://blog.oregonlive.com.

Lambert, B. (2005a, August 13). Evicted immigrants set up tents in new housing battle. The New York Times. Retrieved from http://query.nytimes.com.

. (2005b, December 17). L.I. is ordered to give notice of house raids. The New York Times. Retrieved from http://query.nytimes.com.

. (2006, August 17). Congressman endorses Suffolk County plan to bar contractors from using illegal immigrants. The New York Times. Retrieved from http://query.nytimes.com.

Larabee, M. \& Bernstein, M. (2001, November 29). Feds claim no animosity towards Portland. The Oregonian, p. A1. 
Law Enforcement Engagement Initiative [LEEI]. About: A powerful voice in advancing the dialogue on common sense immigration reform. Retrieved from http://www.leei.us/main/about.

Law, S. (2008, June 5). A year after raid, lives still on hold. The Portland Tribune. Retrieved from http://www.portlandtribune.com.

Leadlay, C. (2005, October 19). Cities expect to have a say on foreign policy. Embassy. Retrieved from http://embassymag.ca.

Learn, S. (2001, Dec. 17). Cities react, Portland catches the heat. The Oregonian, p. C1.

Leave impound law up to voters [Editorial]. (2010, April 7). The Denver Post, p. B12.

Lee, V. (2008, April 12). SF cements its role as 'sanctuary' city. ABC7 News. Retrieved from http://abclocal.go.com.

Lensen, K. (Dec. 2007). New Portlanders speak: Recommendations of the Immigration and Refugee Task Force. Portland, OR: Kristin Lensen Consulting. Retrieved from http://www.portlandonline.com.

Leonard, R. (2008, Nov. 17). The buck stops with public accountability [Editorial]. The Oregonian. Retrieved from http://www.oregonlive.com.

Lewis. P., \& Ramakrishinan, S. (2007). Police practices in immigration-destination cities. Urban Affairs Review, 42(2), 874-900.

Li, W., \& Oberle, A. (2008). Diverging trajectories: Asian and Latino immigration in metropolitan Phoenix. In A. Singer, S. Hardwick, \& C. Brettell (Eds.), Twentyfirst century gateways (pp. 87-104). Washington, DC: Brookings Institute Press.

Liberato, M. (2003, Mar 17). Seattle is the first city to pass immigration privacy law. Asian Week. Retrieved from http://news.newamericanmedia.org.

Library has more work to do [Editorial]. (2005, August 29). The Denver Post, p. B7.

Light, I. (2006). Deflecting immigration: Networks, markets, and regulation in Los Angeles. New York, NY: Russell Sage Foundation.

Lijphart, A. (1975). The comparable-cases strategy in comparative research. Comparative Political Studies, 8(2), 158-177.

Lillis, R. (2010a, April 29). Kevin Johnson urges, then rejects, Arizona economic sanctions. The Sacramento Bee, p. B1. 
. (2010b, May 11). Civil rights groups seek City Council resolution. The Sacramento Bee, p. B2.

. (2010c, May 25). Sacramento council debates Arizona immigration law tonight. The Sacramento Bee. Retrieved from http://www.sacbee.com.

. (2010d, May 26). City looks at Arizona boycott. The Sacramento Bee, B1.

. (2010e, May 26). Sacramento council moves toward Arizona boycott. The Modesto Bee. Retrieved from http://www.modbee.com.

Lindelof, B. (1985, December 18). Sacramento joins list of sanctuaries. Sacramento Bee, p. B1.

- (1987, February 24). No influx into capital found since sanctuary approval. The Sacramento Bee, p. B1.

Lindsey, R. (1985, December 23). Aid to aliens said to spur illegal immigration. The New York Times, p. A1.

Link, M., \& Oldendick, R. (1996). Social construction and white attitude toward equal opportunity and multiculturalism, Journal of Politics, 58(1), 149-168.

Linkhart, Doug (Denver city councilman) in discussion with author, January 5, 2009.

Liu, A., Faulkner, L., Hayes, J., \& Barajas, M. (2007). Poll: 79 percent allow undocumented immigrants to stay for citizenship. The 2007 Sacramento State Annual Survey of the Region. The Institute for Social Research, California State University, Sacramento. Retrieved from: http://www.csus.edu.

Liu, A., Hayes, J., Bennett, G., \& Burton, K. (2006). Four years after September 11. The 2006 Sacramento State Annual Survey of the Region. The Institute for Social Research, California State University, Sacramento. Retrieved from: http://www.csus.edu.

L.L. Decker \& Associates, Inc. (January 7, 2004). A report to the Queen Creek Town Council on day laborer activity [Issue paper]. Retrieved from http://lldecker.com/documents/IssueSummaryPaper1-7-04.pdf.

Lofland, J. (1996). Social movement organizations. Hawthorne, NY: Aldine de Gruyter.

Logan, J., \& Molotch, H. (1987). Urban fortunes. Berkeley, CA: University of California Press. 
Lone protestor arrested at day labor center. (2008, June 17). KATU-TV. Retrieved from http://www.katu.com.

Lopez, C. (1994, November 13). Boycott call wasn't Webb's anger mistakenly unleashed. The Denver Post, p. A1.

Lopez, M. (2000, October 27). Practical politics molded the legacy Serna left Sacramento. The Sacramento Bee, p. B9.

Loveless, S., McCue, C., Surette, R., \& Norris-Tirrell, D. (1996). Immigration and its impact on American cities. Westport, CT: Praeger Publishers.

Ludden, J. (2007, September 13). Virginia town shuts day-laborer center. NPR [Transcript]. Retrieved from http://npr.org.

Luzadder, D. (2002, April 1). Mexican IDs gain in western states. Stateline. Retrieved from http://www.stateline.org.

Lynd, S. \& Lynd, A. (Eds.) (2002). Nonviolence in America: A documentary history. Maryknoll, NY: Orbis Books.

Magagnini, S. (1993, October 30). Matsui: Rhetoric fosters hate crimes. The Sacramento Bee, p. B1. . (2002, August 7). Capital is most diverse big city. The Sacramento Bee, p. A1. . (2011, July 28). Improving Mexican economy draws undocumented home from California. The Sacramento Bee. Retrieved from http://www.sacbee.com.

Magagnini, S., \& Ferriss, S. (2009, October 23). Immigration reform urged by capital's top cop. The Sacramento Bee, p. B2.

Maharidge, D. (1985, October 28). 'I was taught to help people:' Sacramentian could get 55 years for smuggling immigrants. The Sacramento Bee, p. B1.

Maher, J. (2009, October 29). I-300 is out to put the brakes on illegal immigration. Denver Westword News. Retrieved from http://www.westword.com.

Malcolm, A. (2010, May 18). Unwelcome sign out: California mayor wants city declared the opposite of illegal immigrant sanctuary. The Los Angeles Times. Retrieved from http://latimesblogs.latimes.com.

Manning, R. (2007, August 3). Portland day laborer site plan draws controversy. Oregon Public Broadcasting. Retrieved from http://news.opb.org. 
Mapes, J. \& Berstein, M. (2001, December 4). Portland Leahy praises city’s stand on terror issue. The Oregonian, p. D3.

Marcus, P. (2010, May 10). Urging immigration reform. The Denver Daily News. Retrieved from http://www.thedenverdailynews.com.

Markert, J. (2010, March). The changing face of racial discrimination: Hispanics as the dominant minority in the USA. Critical Sociology, 36(2), 307-327.

Markham, C. (2005, September 13). Chandler deters day laborers. East Valley Tribune. Retrieved from http://www.eastvalleytribune.com.

Martineau, P. (2000, September 18). Marching for immigrant amnesty. The Sacramento Bee, p. B1.

. (2001, May 21). Hundreds rally in Sacramento, Calif., for a 'Living Wage.' Knight Ridder Tribune. Retrieved from http://www.highbeam.com.

Mason, J. (1995, May 18). Day laborer facility's first year draws praise. The Houston Chronicle, p. A29.

Massey, D. (1990). Social structure, household strategies, and the cumulative causation of migration. Population Index 56, 3-26.

. (1999). Why does immigration occur? A theoretical synthesis. In C. Hirschman, P. Kasinitz, \& J. DeWind (Eds.), The handbook of international migration (pp.3452). New York, NY: Russell Sage Foundation.

. (2008). New Faces in New Places: The changing geography of American immigration. New York, NY: Russell Sage Foundation.

Massey, D., Durand, J., \& Malone, N. (2002). Beyond smoke and mirrors: Mexican immigration in an era of economic integration. New York, NY: Russell Sage Foundation.

Maushard, L.. (2007, June). Portland's newest labor movement? Indy Media. Retrieved from http://portland.indymedia.org.

Mayer, J. (2008, March 6). City Hall notebook. The Oregonian, p. B3.

Mayor comes to the aid of day laborers. (2007, June 22). The Houston Chronicle, p. B6. 
Mayor in Minnesota boycotts Arizona over new law. (2010, April 28).

Associated Press in The Arizona Republic. Retrieved from http://www.azcentral.com.

McAllister, B. (2002, October 29). Webb spokesman, Tancredo spar over city's plan on Mexican IDs. The Denver Post, p. A3.

. (2003, January 24). Consular ID cards under U.S. scrutiny. The Denver Post, p. A10.

McAllister, S. (1997, July 3). Don't halt aid to legal immigrants. The Denver Post, p. B7.

McCall, W. (2003, August 18). 'Little Beirut' nickname has stuck. Associated Press. Retrieved from http://www.freerepublic.com.

. (2005, January 25). City debates withdrawal from FBI's Joint Terrorism Task Force. The Register Guard. Retrieved from http://www.registerguard.com.

. (2007, June 12). Raid on Portland plant uncovers illegal workers. Associated Press. Retrieved from http://www.katv.com.

McCue, C., \& Norris-Tirrell, D. (2002). The impact of immigration policy on communities [Symposium introduction]. Policy Studies Journal 30(1), 53-57.

McDonald, J. (1991, September 8). Falling through cracks of the law working conditions largely unmonitored. Newsday, 5.

McFadden, C. (2009, June 19). Day labor center marks first year with success, changed minds. Portland Tribune. Retrieved from http://wwwportlandtribune.com.

McGee, P. (2007, May 7). Immigration vote has two sides racing. Fort Worth StarTelegram. Retrieved from http://www.star-telegram.com.

McGhee, T. (2006, January 4). Work centers boost day laborers' lot. The Denver Post, p. C4.

. (2006, June 18). A conversation with Minsun Ji, founder and executive director of Centro Humanitario para los Trabajadores, a nonprofit day labor center in Denver. The Denver Post, p. K3.

McIntosh, D. (2007, July 6). Del Monte raid puts Portland at center of immigration debate. Northwest Labor Press, 108(13). Retrieved from http://www.nwlaborpress.org. 
McKinley, J. (2007, April 28). San Francisco Bay Area reacts angrily to series of immigration raids. The New York Times. Retrieved from http:///www.nytimes.com.

. (2007, November 14). ID cards for residents pass a vote in California. The New York Times. Retrieved from http://www.nytimes.com.

. (2008, April 6). San Francisco campaign tells illegal immigrants they are safe there. The New York Times. Retrieved from http://www.nytimes.com.

McLemore, D., \& Solis, D. (2007, May 16). Cities across the U.S. act on immigration. The Dallas Morning News, p. 1 A.

McQueen, M. (1988, March 27). Groups urge no extension of alien amnesty deadline. The Sacramento Bee, p. B3.

McVea, D. (1992a, August 13). Critics call INS raid illegal. The Oregonian, p. B1. . (1992b, September 2). Portland INS chief won't explain raid to task force. The Oregonian, p. E5.

. (1992c, September 15). Police limit deportation arrest help. The Oregonian, p. B4.

. (1992d, October 11). INS official defends raid on apartments. The Oregonian, p. D21.

. (1992e, October 31). Wyden says Portland police policy on immigration is a model. The Oregonian, p. B3.

. (1993, February 19). Police, INS agent team up in Old Town. The Oregonian, p. C3.

McWilliams, H. (2010, April 30). DPS bars work trips to Arizona. The Denver Post, p. A1.

Megan, R. (2002, July 14). New day-laborer center offers fairness, comfort. The Denver Post, p. B2.

Menia, J. \& Fricklas, A. (1999, Sept. 17). Ceremony draws 620 closer to their dreams [Editorial]. Rocky Mountain News. Retrieved from http://www.rockymountainnews.com.

Merina, V. (1985, November 17). Cities vs. the INS. The New York Times, p. 1. 
Meyers, E. (2004). International immigration policy: A theoretical and comparative analysis. New York, NY: Palgrave MacMillian.

Meyer, J. (2005, June 6). Suspect's capture brings communal sigh of relief. The Denver Post, p. A6.

. (2011, June 22). Denver council to consider repealing 2008 car-impound initiative aimed at illegal immigrants. The Denver Post. Retrieved from http://www.denverpost.com.

Mexican American Legal Defense and Educational Fund [MALDEF]. (n.d.) Legal and policy analysis: Local Illegal Immigration Relief Act ordinances. Los Angeles, CA: Author. Retrieved from http://www.maldef.org.

Mexican Consulate deluged with ID applications. (2002, October 8). KMGH-TV/ 7NEWS. Retrieved from http://www.thedenverchannel.com.

Michelson, H. (1986, July 9). Oakland invites S. African refugees. The Sacramento Bee, p. B6.

Milbourn. T. (2007, March 3). Coalition urges hiring center for capital. The Sacramento Bee, p. A1.

Miles, M. \& Huberman, A. (1994). Qualitative data analysis, (2nd ed.). Thousand Oaks, CA: Sage Publications.

Miletich, S. (2010, May 18). Sacramento Police Chief Rick Braziel would listen, the make changes if hired as Seattle's next chief. The Seattle Times. Retrieved from http://seatletimes.nwsource.com.

Millard, A., \& Chapa, J. (2004). Apple pie and enchiladas: Latino newcomers in the rural Midwest. Austin, TX: University of Texas Press.

Mintrom, M. (1997, July). Policy entrepreneurship and the diffusion of innovation. American Journal of Politic Science, 41(3), 738-770. . (2000). Policy entrepreneurship and school choice. Washington, DC: Georgetown University Press.

Mintrom, M., \& Norman, P. (2009). Policy entrepreneurship and policy change. Policy Studies Journal 37, 649-667.

Mitchell, K. (2006, June 2). Sanctuary billboard gets mixed reception. The Denver Post, p. B2. 
Mitchell, R. (2002, April 10). Finding folks without papers is not cops' job. The Oregonian, p. D2.

Mitnik, P., \& Halpern-Finnerty, J. (2010). Immigration and local governments: Inclusionary local policies in the era of state rescaling. In M. Varsanyi (Ed.), Taking local control (pp. 51-72). Stanford, CA: Stanford University Press.

Mollenkopf, J. (1999). Urban political conflicts and alliances: New York and Los Angeles compared. In C. Hirschman, P. Kasinitz, \& J. DeWind (Eds.), The handbook of international migration (pp. 412-422). New York, NY: Russell Sage Foundation.

Mollenkopf, J., Olson, D., \& Ross, T. (2001). Immigrant political participation in New York and Los Angeles. In M. Jones-Correa (Ed.), Governing American Cities: Interethnic coalitions, competition, and conflict (pp. 17-70). New York, NY: Russell Sage Foundation.

Money, J. (1999). Fences and neighbors: The political geography of immigration control. Ithaca, NY: Cornell University Press.

Moore, S. (1997). Immigration and the rise and decline of American cities: Essays in public policy. Stanford, CA: Hoover Institution, Stanford University.

Morgan, R. (2002, July 14). New day-laborer center offers fairness, comfort. The Denver Post, p. B2.

Morris, D. (2010, May 4). Huntington Town Board to close day labor hiring center. Newsday. Retrieved from http://www.newsday.com.

Mossberger, K., \& Stoker, G. (2001). The evolution of urban regime theory. Urban Affairs Review, 36(6), 810-35.

Moy, K. (1996, October 23). Council splits over votes on pot, logging: City, county agendas provide time for non-local issues. The Sacramento Bee, p. B3.

Mulero. E. (2006, January 19). Day laborers still seek jobs near Chandler intersection. The Arizona Republic, p. B5.

Murray, M. (2002). City profile Denver. Cities, 19(4), 283-294.

Muse, D. (1999, July 22). Letter to Thomas Sanchez, Chief of Police. Formal legal opinion, 1-5. Denver, CO: City and County of Denver, Office of City Attorney. 
Nasser, H. (February 16, 2005). 'New Urbanism' embraces Latinos. USA Today. Retrieved from http://www.usatoday.com.

National Association of Counties [NACO]. (2006). State criminal alien assistance program. Washington, DC: Author. Retrieved from http://www.naco.org.

National Immigration Forum (2007, August). Immigration law enforcement by state and local police [Backgrounder]. Washington, DC: Author. Retrieved from $\mathrm{http}: / / \mathrm{www}$.immigrationforum.org.

. (2008, August). Out of focus: The hidden crisis of the latest backlog in the naturalization process. Washington, DC: Author. Retrieved from http://www.immigrationforum.org.

National Immigration Law Center [NILC]. (2004a, July). Annotated chart of laws, resolutions, and polices instituted across the U.S. limiting the enforcement of immigration laws by local authorities. Los Angeles, CA: Author. Retrieved from http://www.nilc.org.

. (2004b, November). Sample language for policies limiting the enforcement of immigration law by local authorities. . Los Angeles, CA: Author. Retrieved from http://www.nilc.org.

National League of Cities [NLC]. (2004, May 5). Cities scramble for immigrants. Washington, DC: Author. Retrieved from http://www.nlc.org.

. (2006, January 31,). About cities: Form of government and types of election in 30 largest cities. Retrieved from http://www.nlc.org.

Navratil, L. (2011, July 12). Denver City Council overrules voter initiative on unlicensed drivers. The Denver Post. Retrieved from http://www.denverpost.com.

Neuman, G. (1996). Strangers to the Constitution: Immigrants, borders, and fundamental Law. Princeton, NJ: Princeton University Press.

New York City Office of Communications. (2010, April 29). New York City Council, citywide leaders and advocates denounce Arizona immigration law [Press release]. Retrieved from http://council.nyc.gov.

New York Civil Liberties Union. (2004, February 4). New York City council adopts forceful resolution affirming rights and liberties in the face of anti-terrorism initiatives. Retrieved from http://www.nyclu.org/node/336. 
New York Mayor's Office of Immigrant Affairs (n.d.). Executive orders and local laws. Retrieved from http://www.nyc.gov.

New website urges boycott of Sacramento city businesses. (2010, June 21). From the Capital. Retrieved from http://www.fromthecapital.com.

Newton, C. \& Kiefer, M. (2008, May 25). Phoenix Police widen immigration enforcement. Arizona Republic. Retrieved from http://www.azcentral.com.

Niedhardt, C. (2012). Translating ideas into action: The policy entrepreneur and the public policy process. [Conference paper, World Congress of Political Science, Madrid 2012 ]. International Political Science Association. Retrieved from http://www.ipsa.org.

Numbers USA. (n.d.). The need for state and local immigration law enforcement of immigration laws. Retrieved from https://www.numbersusa.com.

O’Byrne, H. (2008). Municipal overreaching: Federal preemption as it applies to town ordinances outlawing the rental of housing to undocumented immigrants. Texas Hispanic Journal of Law \& Policy, 14(1), pp. 69-89.

O'Driscoll. P. \& El Nasser, H. (2004, September 30). Demographic scales are tipping in Denver, elsewhere. USA Today, 2A.

O’Dowd, P. (2010, May 4). Cities, businesses boycott Arizona over new law. National Public Radio. Retrieved from http://www.npr.org.

O'Grady, B. (n.d.). Work space: Day laborers fight for a corner of their own. Retrieved from http://www.inthesetimes.com.

O'Leary, Mary E. (2006, Dec. 21) Group wants city ID cards ready sooner. New Haven Register. Retrieved from http://www.nhregister.com.

O’Neil, K. (2003, April 1). Consular ID cards: Mexico and beyond. Migration Information Source. Washington, DC: Migration Policy Institute. Retrieved from http://www.migrationinformation.org.

O'Reilly, B. (2005, May 16). Unresolved problem: Interview with Peter Boyles. The O'Reilly Factor Show. Retrieved from http://www.foxnews.com.

Odem, M. (2008). Unsettled in the suburbs: Latino immigration and ethnic diversity in Metro Atlanta. In A. Singer, S. Hardwick, C. Brettell (Eds.), Twenty-first century gateways (pp. 105-136). Washington, DC: Brookings Institution Press. 
Oliver, G. \& Learn, S. (2001, November 30). City Attorney: This isn't political. The Oregonian, A01.

Oliver, T. \& Paul-Shaheen, P. (1997). Translating ideas into action: Entrepreneurial leadership in state health care reforms. Journal of Health Politics, Policy and Law, 22(3), 721-88.

Olivo, A. (2009, May 12). Immigration raid leave damaging mark on Postville, Iowa. The Los Angeles Times. Retrieved from http://latimes.com.

Oregon ralliers decry new Arizona law. (2010, June 22). Catholic Sentinel. Retrieved from http://www.catholicsentinel.org.

Oregonians for Immigration Reform [OFIR]. (2010, December). OFIR - Past and present. OFIR Newsletter. Retrieved from http://www.oregonir.org.

Ortiz, F. (1994, November 9). Hispanic community fights officer's return. The Oregonian, p. B12.

. (1995, February 13). Panel wants INS agent off county's gang team. The Oregonian, p. B2.

Osher, C. N. (2008a, May 5). Driver proposal stirs bias claims. The Denver Post, p. A15. . (2008b, July 31). Car-impound idea too costly, mayor says. The Denver Post, p. B1.

. (2008c, August 13). Unlicensed motorists at red light. The Denver Post, p. B1.

. (2008d, August 14). Guidance awaited on seizing cars. The Denver Post, p. B2.

. (2008e, September 12). Impound not automatic. The Denver Post, p. B1.

. (2009, April 13). City evades impound rule. The Denver Post, p. A11.

. (2010a, April 4). Repeal impoundment law, say 2 on council. The Denver Post, p. B8.

. (2010b, April 8). Impound -law repeal advances. The Denver Post, p. B2.

. (2010c, April 14). Councilman alters strategy on impound law. The Denver Post, p. B4. 
. (2010d, April 14). More news. The Denver Post. Retrieved from http://www.denverpost.com.

. (2010e, April 19). Initiative 100: City to pay over seized cycle. The Denver Post, p. A17.

. (2010f, May 11). Immigration reform urged Denver council passes proclamation calling on Obama, Congress to act. The Denver Post, p. B2.

. (2010g, September 10). Hickenlooper out of line on illegal immigration, foes say. The Denver Post. Retrieved at http://www.denverpost.com.

Otani, E. (1996, August 23). Radio host yanked for week over anti-immigrant remarks. The Sacramento Bee, p. B1.

Pardillo, V. (2000). Strangers to these shores $\left(6^{\text {th }}\right.$ ed). Boston, MA: Allyn and Bacon. . (2005). Diversity in America, ( $2^{\text {nd }}$ ed), Thousand Oaks, CA: Pine Forge Press.

Pankratz, H. (2001, November 2). Inside Denver's anti-terrorism command post. The Denver Post, p. A18.

Parker, L., \& McMahon, P. (2001, April 9). Immigrant groups fear backlash rhetoric, actions have intensified coast to coast since release of data from Census 2000, activist report. USA Today. Retrieved from http://www.usatoday.com.

Parrado, E. \& Kandel, W. (2008). New Hispanic migrant destinations: A tale of two industries. In D. Massey (Ed.), New faces in new places: The changing geography of America immigration (pp. 99-123). New York, NY: Russell Sage Foundation.

Pasadena condemns Arizona immigration law. (2010, May 18). Associated Press in The San Diego Union-Tribune. Retrieved from http://www.utsandiego.com.

Passel, J. S. (2006, March 7). The size and characteristics of the unauthorized migrant population in the U.S. Washington, D.C.: Pew Hispanic Center.

Patton, M. (1990). Qualitative evaluation and research methods ( $2^{\text {nd }}$ ed.). Newbury Park, CA: Sage.

Pear, R. (1997, May 4). Budget agreement restoring benefits to some legal immigrants. The New York Times, p. A30.

Peeples-Salah, D. (1997, May 15). Sweep brings arrests of 35 for drug deals. The Oregonian, p. D5. 
Pein, C. (2008a, March 12). New tent city. Willamette Week. Retrieved from http://www.wweek.com.

. (2008b, April 30). Work in progress. Willamette Week. Retrieved from http://www.wweek.com.

Perez-Treviño, E. (2010, May 19). Brownsville adopts resolution condemning Arizona immigration law. The Monitor. Retrieved from http://www.themonitor.com.

Perkins, E. (1986, Oct. 29). Drive seeks to end sanctuary city's refugee protection resolution. The Sacramento Bee, p. B1.

Peter, G. (1994, August 26). INS raids 2 Denver companies, nabs 61 undocumented immigrants. The Denver Post, p. B7.

Petrillo, L. (1992, July 22). Snesko's INS plan sparks political spat. The San Diego Union-Tribune, pp. B1:2, B4:3, 6.

Pinkerton, J. (2008, June 25). Controversial East End day labor center to shut down. Huston Chronicle. Retrieved from http://www.chron.com.

Pham, H. (2004). The inherent flaws in the inherent authority position: Why inviting local enforcement of immigration laws violates the Constitution. Florida State University Law Review 31, 965-1003.

Philp, T. (1992, March 26). No matter how high he rose, Kearns was a street cop. The Sacramento Bee, p. A22.

Police leaders from across the country call for immigration reform. (2009, October 22). The Cypress Times. Retrieved from http://mexicanexpulsions.blogspot.com.

Portillo, E. (1989, September 29). Poway looks at tougher law to close migrant camps. The San Diego Union-Tribune, B1.

Portland Copwatch. (1998a, April). INS declares open season on Latinos. Peoples' Police Report \#14. Retrieved from http://www.portlandcopwatch.org.

. (1998b, August). INS chief meets with community. Peoples' Police Report \#15. Retrieved from http://www.portlandcopwatch.org.

. (1998c, August) The INS versus workers' rights: La lucha sigue. Peoples' Police Report \#15, INS update. Retrieved from http://www.portlandcopwatch.org/PPR15/insupdate.html. 
Portland decision highlights differing attitudes. (2001, Nov. 22). Cable News Network. Retrieved from http://edition.cnn.com.

Portland Mayor's Office. (2007, June 12). Mayor Potter's statement on arrests Tuesday (6/12) by immigration \& customs enforcement officers. Retrieved from http://www.portlandonline.com.

Portland Office of Neighborhood Involvement [ONI]. (2003a, May). Interwoven tapestry project. The Other Side of the Fence [Newsletter], 1-7. Retrieved from http://www.portlandonline.com.

. (2003b, June). Planning at the roots: Low-income and communities of color in Portland, Oregon, 1-67. Retrieved from http://dr.archives.pdx.edu/xmlui/handle/psu/8627.

Portland Police Bureau (2002a). Portland Police Bureau 2002 Statistical Report: Building Partnerships through Community Policing, 1-21.

Portland Police Bureau. (2002b, November 4). Chief Kroeker creates Muslim/Arab Advisory Council [Press release]. Portland, Oregon: Portland Police Bureau, Office of Public Information. Retrieved from http://gis.ci.portland.or.us.

Portland snubs FBI anti-terrorism team. (2005, April 23). Associated Press. Retrieved from http://community.seattletimes.nwsource.com.

Powell, M. (June 10, 2005). New tack against illegal immigrants: Trespassing charges. The Washington Post, p. A1.

Preston, J. (2006, September 2). Pennsylvania town delays enforcing tough immigration law. The New York Times, p. 11. . (2007, July 27). Judge voids ordinance on illegal immigration. The New York Times. Retrieved from http://www.nytimes.com.

Price, M., \& Singer, A. (2008). Edge gateways: Immigrants, suburbs, and the politics of reception in metropolitan Washington. In A. Singer, S. Hardwick, C. Brettell (Eds.), Twenty-first century gateway (pp. 137-170). Washington, DC: Brookings Institution Press.

Prince William to check immigration status. (2007, July 11). The Washington Times. Retrieved from: http://www.washingtontimes.com

Pring, D. (2005, January 6). Rally planned to oppose day laborers. The Redondo Beach News. Retrieved from http://tbrnews.com. 
Prop 187: Call to citizenship [Editorial]. (1995, April 1). The Sacramento Bee, p. B8.

Proposed day-labor center in south Sac finds world of support. (2007, October 28). Sacramento Business Journal. Retrieved from http://www.bizjournals.com/sacramento.

Provine, D. (2010). Local immigration policy and global ambitions in Vancouver and Phoenix. In M. Varsanyi (Ed.), Taking local control (pp. 217-238). Stanford, CA: Stanford University Press.

Pulaski, A. (1997, November 9). Immigration raid hits workplace. The Oregonian, p. C1.

Quintero, F. (2006, October 24). Rice rips ads saying he's 'soft' on illegals. Rocky Mountain News. Retrieved from http://www.rockymountainnews.com.

Quiroz, J. (1995). Together in our differences: How newcomers and established residents are rebuilding American communities. Washington, DC: National Immigration Forum.

Ramakrishnan, S. \& Wong, T. (2010). Partisanship, not Spanish: Explaining municipal ordinances affected undocumented immigrants. In M. Varsanyi (Ed.), Taking local control (pp. 73-96). Stanford, CA: Stanford University Press.

Ray, B. (October 1, 2003). The role of cities in immigration integration. Migration Information Source. Retrieved from http://www.migrationinformation.org.

Read R. (2000, December 14). Overwhelmed I.N.S. develops culture of abuse, racism. The Oregonian, p. A1. . (2007, June 15). Raid reflects feds' new tack: Target workers. The Oregonian, p. A1.

Read, R. \& Sullivan, J. (2000a, August 3). Confidence in Beebe is gone. INS News, The Oregonian. Retrieved from http://www.oregonlive.com.

. (2000b, September 13). INS may take action soon on results of inquiry into Portland, Ore Office. INS News, The Oregonian. Retrieved from http://www.oregonlive.com.

. (2000c, September 20). INS' Beebe leaves. The Oregonian. Retrieved from http://www.pulitzer.org/archives/6508.

Recall of the Sacramento City Council, California (2010). In Ballotpedia. Retrieved from http://ballotpedia.org. 
Rede, G. (1992c, August 25). Potter pledges policy changes in federal raids. The Oregonian, p. C6.

. (1992b, August 27).Delegation asks INS why it conducted raid. The Oregonian, p. C6.

. (1992a, August 30). INS raids also net long-lasting trauma among children. The Oregonian, Forum, p. P4.

. (1993, April 1). Hispanic leaders seek INS official's ouster. The Oregonian, p. C8.

Reid, T. (2002, Dec. 2). Identifying a way to help Mexicans living in the U.S. The Washington Post, p. A3.

Reese, P. (2010, June 18). Arizona boycott: Will council turn down campaign contributions? [Blog]. The Public Eye Watchdog Report. Retrieved from http://blogs.sacbee.com/the-public-eye/2010/06.

Reform Immigration for America. (n.d.) Denver, CO passes resolution of immigration reform. Retrieved from http://reformimmigrationforamerica.org.

Reinink, A. (2001a, September 16). Plan would reward bilingual city staffers. The Denver Post, p. B8.

. (2001b, October 12). Raises ok'd for bilingual workers City agency enacts wage differential. The Denver Post, p. B1.

Reitz, J. (2002). Host societies and the reception of immigrants. Host societies and the reception of immigrants. La Jolla, CA: Center for Comparative Immigration Studies, UCSD, 1-18.

Riccardi, N. (2006, January 3). New Denver law aims to ensure pay for immigrant day laborers. The Los Angeles Times, p. A9.

Richardson, V. (1994, November 12). Anti-immigration trend may widen: Denver mayor backs California boycott. The Washington Times, p. A4. . (2005a, May 12). Alien flees after cop dies. The Washington Times, p. A14.

. (2005b, May 17). Rally targets Denver sanctuary rules. The Washington Times, p. A5. 
. (2005c, August 1). Library's Spanish outreach criticized. The Washington Times. Retrieved from http://www.washingtontimes.com.

. (2005d, August 26). Library to cancel 4 series of Spanish adult comic books.

The Washington Times, p. A3.

. (2008, September 11). Deaths fan immigration debate. The Washington Times, p. A1.

Rigby, E., Bruch, S., \& Soss, J. (2007). Race, class, and state provision. Paper prepared for State Politics and Policy Conference, Austin, TX, February 2007.

Ridgley, J. (2008). Cities of refuge. Urban Geography 29(1), 53-77.

Riley, M. (2002a, March 15). Limits on terror fight eyed. The Denver Post, p. A1.

. (2002b, April 18). Day-laborer center toils at getting started. The Denver Post, p. A1.

. (2002c, April 22). Immigration bill has police uneasy. The Denver Post. Retrieved from http://www.denverpost.com/archives.

. (2002d, June 19). Job center struggling to survive. The Denver Post, p. B1.

. (2002e, October 4). City begins accepting Mexico IDs. The Denver Post, p. A1.

. (2002f, October 10). Mexican ID cards caught in growing debate. The Denver Post, p. B2.

. (2005, January 16). Deportation efforts: 1 step ahead, 3 back. The Denver Post, p. A1.

. (2006, June 13). Court bars immigration vote Colo. justices keep initiative off ballot. The Denver Post, p. A1.

Rinehart, T. \& Robinson, T. (n.d.) El Centro Humanitario, 1-36. A report by Political Science students at the University of Colorado, Denver/HSC. Retrieved from http://centrohumanitario.org.

Rivers, R. (2005, August 19). The duty of a public library. The Denver Post, p. B7.

Roberts, M. (2010, April 30). Arizona immigration bill: Colorado students plan afternoon protest walkout. Westword. Retrieved from http://blogs.westword.com. 
. (2010, May 10). Immigration reform must happen now, says Denver City Council proclamation. Westword. Retrieved from http://blogs.westword.com.

Robertson, S. \& Camerini, M. (Directors and Producers). (2010). How democracy works Now: Twelve stories [Documentary]. United States.

Rodríguez, C. (2004, July 20). Day labor: Pay by day. The Denver Post, p. F1.

. (2005a, May 19). Killing fuels hysteria over immigrants. The Denver Post, p. F1.

. (2005b, August 2). Bashing of immigrants must stop. The Denver Post, p. F1.

. (2005c, August 11). Vulgar way to protest vulgarity. The Denver Post, p. F1.

. (2005d, December 8). Zealotry patrols the border. The Denver Post, p. F1.

. (2008). The significance of the local in immigration regulation. Michigan Law Review 106(4), 567-642.

Rodríguez, C., Chishti, M. \& Nortman, K. (2010). Legal limits of immigration federalism. In M. Varsanyi (Ed.), Taking local control (pp. 31-50). Stanford, CA: Stanford University Press.

Rodríguez, M. (2006, July 19). Vista sued over day-laborer law by rights groups. San Diego Union-Tribune, p. B3.

Rodríguez, N. (1999). U.S. immigration and changing relations between African Americans and Latinos. In C. Hirschman, P. Kasinitz, \& J. DeWind (Eds.), The Handbook of international migration (pp. 423-32). New York, NY: Russell Sage Foundation.

Roe, A. (2002, December 11). All quiet in Little Beirut. Willamette Week. Retrieved from http://www.wweek.com.

Roper, P. (May 23, 2005). Illegal immigrants move easily among state, local police. The Pueblo Chieftain. Retrieved from http://www.chieftain.com.

Rosen, M. \& Yoon, D. (2009). 'Bringing coals to Newcastle'? Human rights, civil rights and social movements in New York City. Global Networks, 9(4), 507-528.

Ross, B., \& Levine, M. (2001). Urban politics: Power in metropolitan America, (6 ${ }^{\text {th }}$ ed.). Itasca, IL: F.E. Peacock Publishers, Inc. 
Rother, L. (1986, July 13). The risks of providing aid and comfort. The New York Times, p. 7.

Rubin, J. (2012, February 29). LAPD panel eases car impound policy. The Los Angeles Times. Retrieved from http://www.latimes.com.

Rubin, J. \& Esquivel, P. (2011, December 14). LAPD to change impound rules. The Los Angeles Times. Retrieved from http://www.latimes.com.

. (2012, February 23). LAPD chief joins driver's license fray. The Los Angeles Times. Retrieved from http://www.latimes.com.

Rubiner, B. (2008, May 27). After immigration raid, Iowans ask why. Time Magazine. Retrieved from http://www.time.com.

Rush, J. (2011, January 26). Business owner calls for day laborer camp. The Plano Star. Retrieved from http://www.planostar.com.

Ryan, A. (2006, June 14). ICE arrests about 2,000 illegal immigrants. Breit Brat TV. Retrieved from http//:www.breitbart.com.

Sachs, S. (2002, December 28). New York, citing security, rejects Mexican ID cards. The New York Times, p. 4. . (2003, July 23). Mayor's new immigrant policy. The New York Times, p. A1.

Sacramento City Council. (1986, July 1). Meeting minutes. Retrieved from http://www.records.cityofsacramento.org.

. (1996 August 20) Agenda item 14.1: Mexican American community responding to Radio Hate Crime, 1-5. Retrieved from http://www.records.cityofsacramento.org.

. (1997, February 25). Meeting minutes, Agenda Item 4.2: Welfare Reform. . Retrieved from http://www.records.cityofsacramento.org. . (1997, July 28). Meeting minutes, Agenda Item 4.2: Framework for Comprehensive Welfare Reform Planning. . Retrieved from http://www.records.cityofsacramento.org. . (2003, January 9). Agenda Item 13.1: Working Poor Workshop. Retrieved from http://www.records.cityofsacramento.org. 
Sacramento City Council will discuss Arizona law. (2010, June 18). From the Capital. Retrieved from http://www.fromthecapital.com.

Sacramento Economic Development Department. (2003, February 6). Meeting Agenda Item 4.2: Promotion of the Greater Sacramento Area as a Regional Center for Pacific Rim/Western United States Homeland Security Research, Training and Logistical Activities. Retrieved from http://www.records.cityofsacramento.org.

Sacramento Mayor Joe Serna Jr. dies. (1999, November 8). The San Francisco Chronicle. Retrieved from http://www.sfgate.com.

Sacramento Police Reach Out to Illegal Immigrants. (2009, Oct. 22). KXTV/News 10. Retrieved from http://www.news10.net.

Sacramento's changing face [Editorial]. (1991, March 5). The Sacramento Bee, p. B6.

Sacramento County, Department of Human Services. Welfare reform strategic planning process, January 29, 1997.

Sacramento's diverse workforce defies labels. (2006, November 26). Sacramento Business Journal. Retrieved from http://www.bizjournals.com.

Saker, A. (2008, June 12). Marchers protest raids in workplace. The Oregonian, pp. B1, B2.

Salvi, S. (n.d.). Sanctuary cities: What are they? [Fact sheet]. Ohio Jobs \& Justice PAC. Retrieved from: http://www.ojjpac.org.

San Francisco Immigrant Rights Commission. (2006). Immigrants Right Commission Annual Report, 2006. Retrieved from http://www.sf-hrc.org.

San Francisco Mayor's Office of Communications. (2008, April 2). Mayor Newson launches sanctuary city outreach campaign [Press release]. Retrieved from http://www.sfgov.org.

San Francisco Mayor's Office of Housing. (2005). Five year consolidated plan, 2005. Retrieved from http://www.sfgov.org.

Sanchez, E. (1988, March 18). Despite fear, aliens apply for amnesty. The Sacramento Bee, p. B1.

. (1989, February 17). '88 was big year for new citizens. The Sacramento Bee, p. B1. 
. (1992, September 16). Citizenship application flood INS office. The Sacramento Bee, p. B1.

. (1995, May 11). INS adding staff to help tackle giant backlog. The Sacramento Bee, p. B4.

. (1998, March 18). Despite fear, aliens apply for amnesty. The Sacramento Bee, p. B1.

. (2002, April 17). Groups laud INS work to speed up citizenship. The Sacramento Bee, p. B2.

Sanchez, L. (February 6, 2001). County spent $\$ 50$ million on immigrants in '99, study finds. The San Diego Union Tribune, p. B1.

Sanchez, R. (2005, May 17). Groups protest illegal immigration. The Denver Post, p. B4.

Sanctuary starts at home for Tancredo [Editorial]. (2005, May 26). The Denver Post, p. B6.

Sanders, J. (1986a, July 3). Council may be sued for its sanctuary policy. The Sacramento Bee, p. B3.

. (1986b, July 9). Crowd fumes as city sticks to sanctuary. The Sacramento Bee, p. B1.

. (1986c, September 16). Sanctuary foes bid for initiative to void council resolution. The Sacramento Bee, p. B3.

. (1986d, September 20). U.S. officials hit city on sanctuary council stand, federal aid called irreconcilable. The Sacramento Bee, p. B1.

. (1987a, February 24). No influx into capital found since sanctuary. The Sacramento Bee, p. B1.

. (1987b, April 21). Foes lose sanctuary ballot bid. The Sacramento Bee, p. B1.

. (2003, April 29). Mexican ID cards advance. The Sacramento Bee, p. A1.

Sandoval, J., Johnson, H., \& Tafoya, S. (2002, August). Who's your neighbor? California Counts: Population Trends and Profiles, 4(1). San Francisco, CA: Public Policy Institute of California. 
Santos, F. (2006, September 17). Day laborers' lawsuit casts spotlight on a nationwide conflict. The New York Times. Retrieved from http://www.nytimes.com.

Sarche, J. (2002, October 31). Group alleges Denver policies violated federal law. Associated Press. Retrieved from http://nl.newsbank.com.

Sassen, S. (1998). Globalization and its discontents. New York, NY: The New Press

Savage, D., \& Gaouette, N. (2007, July 27). Judge rejects Hazleton law on immigrants. The Los Angeles Times. Retrieved from http://articles.latimes.com.

Schabner, D. (2003, July 1). Patriot revolution? Cities from Cambridge to Berkeley reject anti-terror measure. $A B C$ News. Retrieved from http://abcnews.go.com.

Schmidt, B. (2011a, February 15). Portland's JTTF debate reveals how oversight agreement with FBI not followed for bomb plot. The Oregonian. Retrieved from http://www.oregonlive.com.

. (2011b, February 16). FBI didn’t know to tell mayor of plot. The Oregonian, pp. A1, A6.

. (2011c, March 11). A hot issue, but only in Portland. The Oregonian, pp. A1, A6.

Schoenholtz, A. (2005). Newcomers in rural America: Hispanic immigrants in Rogers, Arkansas. In E. Gozdziak \& S. Martin (Eds.), Beyond the gateway: Immigrants in a changing America (pp. 213-40). New York, NY: Lexington Books.

Schroyer, J. (2008, July 4). Measure would impound. The Colorado Statesman. Retrieved at http://www.coloradostatesman.com.

Scolforo, M. (July 15, 2006). Town launches controversial illegal immigration law. The Oregonian, p. A2.

Scott, C., Maass, B., \& Hartfiled, K. (2005, November 17). The human smuggler. $K C N C-T V$ (Denver) [Investigative report]. Retrieved from http://www.ire.org.

Scott, J. (1988, June 6). Member explains sanctuary movement. The Oregonian, p. B5.

Seghetti, L., Viňa, S., \& Ester, K. (2005, October). Enforcing immigration law: The role of state and local law enforcement. Congressional Research Service, Library of Congress. 
Seif, H. (2010). 'Tired of illegals:' Immigrant driver's licenses, constituent letters, and shifting restrictionist discourse in California. In M. Varsanyi (Ed.), Taking local control (pp. 275-295). Stanford, CA: Stanford University Press.

Seifert, J. (2012). Policy change and policy entrepreneurship. [Conference paper, World Congress of Political Science, Madrid 2012 ]. International Political Science Association. Retrieved from http://www.ipsa.org.

Sepúlveda, M., van Banning, T., Gudmundsdóttir, G., Chamoun, C., \& van Genugten, W. (2004). Human rights reference handbook (3rd ed. rev. ed.). Ciudad Colon, Costa Rica: University of Peace.

Shanley, W. (2004, August 15). Agency marks 2 years pairing migrants, jobs. The Denver Post, p. C2.

Shuman, M. (1986-87). Dateline mainstreet: Local foreign policies. Foreign Policy, Winter, 154-174.

Sifuentes, E. (2007, June 16). Carlsbad uses 'hawking' ordinance to ticket day laborers. North County Times. Retrieved from http://www.nctimes.com.

. (2009, November 1). Undercover sting used to cite, deport Carlsbad day laborers. North County Times. Retrieved from http://www.nctimes.com.

Silvestri, M. (2008, January 10). 'Anti-sanctuary city’ push splits town. The Examiner. Retrieved from http://www.examiner.com.

Simon, B., González-Campeán, F., Artenstein, I. \& Guerrero, S. (Producers) and Arua, Sergio (Director). (2004). A day without a Mexican [Motion picture]. USA:

Xenon.

Simpson. K. (2001, April 1). Foreign workers key to builders Immigrants take unwanted jobs. The Denver Post, p. A18.

. K. (2006, May 3). Peña brings ideas to table. The Denver Post, A1.

Singer, A. (2008). Twenty-first-century gateways: An introduction. In A. Singer, S. Hardwick, \& C. Brettell (Eds.), Twenty-first century gateways (pp. 3-30). Washington, DC: Brookings Institute Press.

Singer, A. \& Wilson, J. (2006, September). From 'there' to 'here': Refugee resettlement in metropolitan America. Washington, DC: The Brookings Institute, Living Cities Census Series. 
. (2007, March). Refugee resettlement in metropolitan America. Migration

Information Source. Retrieved at http://www.migrationinformation.org.

Sinisi, S. (1997, June 24). Bright new Denver image emerges. The Denver Post, p. A1.

Sister Cities Council of Sacramento. (n.d.). A message from Mayor Kevin Johnson

[Brochure]. Sacramento, California: Kevin Johnson. Retrieved from http://www.cityofsacramento.org/sistercities/index.htm.

Sjoberg, G., Williams, N., Vaughan, T., \& Sjoberg, A. (1991). The case study approach in social research. In J. Feagin, A. Orum, \& G. Sjoberg (Eds.). A case for the case study (pp.27-79). Chapel Hill, NC: University of North Carolina Press.

Skelton, G. (1999, November 11). Mourning a role model whose lessons live on. The Los Angeles Times. Retrieved from http://www.latimes.com.

Skerry, P. (1995). Many borders to cross: Is immigration the exclusive responsibility of the Federal Government? Publius 25(3), 71-85.

Skop, E., \& Buentello, T. (2008). Austin: Immigration and transformation deep in the heart of Texas. In A. Singer, S. Hardwick, \& C. Brettell (Eds.), Twenty-first century gateways (pp. 257-280). Washington, DC: Brookings Institute Press.

Smith, D. (1997, June 24). Clinton asks mayors to help rebuild cities. The Sacramento Bee, p. A4.

Smith, H., \& Furuseth, O. (2008). The "Nuevo South": Latino place making and community building in the middle-ring suburbs of Charlotte. In A. Singer, S. Hardwick, \& C. Brettell (Eds.), Twenty-first century gateways (pp. 281-307). Washington, DC: Brookings Institute Press.

Smith, J. (2010, June 24). Recall rally staged over Sacramento boycott of Arizona. News 10. Retrived from http://www.news10.net.

Smith, J., \& Edmonston, B. (1997). The new Americans: Economic, demographic, and fiscal affects of immigration. Washington, DC: National Academy Press. Retrieved from http://bob.nap.edu/html/newamer/index.html.

Smith, M. [Matt]. (2005, May 22). Helping immigrant workers on Denver streets. The Denver Post, p. E4.

. [Morgan]. (2010, April 29). Sacramento Mayor Kevin Johnson NOT joining Arizona Boycott. SF Weekly [Blog]. Retrieved from http://blogs.sfweekly.com. 
Smith, R. (1985, December 7). Move to aid Central American refugees. The San Francisco Chronicle. Retrieved from http://nl.newsbank.com. . (2003, November). Low pay, high risk: State models for advancing immigrant workers' rights. Olympia, WA: National Employment Law Project (NELP).

. (2004, February). Drafting day labor legislation: A guide for organizers and advocates. Olympia, WA: National Employment Law Project (NELP).

Snell, J. \& Anderson, D. (1997, July 10). INS raids ‘job corner’ on northeast Burnside. The Oregonian, p. D2.

Solís, D. (2009, October 23). Deputy chief joins battle over immigration. The Dallas Morning News, p. 7B.

Sosa, R. (2008, June). Voz to hold ceremony for new day labor center tomorrow. CAUSA Communication Department [Blog]. Retrieved form http://causaoregon.blogspot.com.

Spencer, J. (2005a, May 23). Matching workers to legal IDs remains the exception. The Denver Post, p. B5. . (2005b, August 15). Book uproar really about the readers. The Denver Post, p. B1. . (2006, April 14). 'Sanctuary’ bill much ado about nada. The Denver Post, p. B1.

St. Paul mayor boycotts Arizona over new law. (2010, April 29). Associated Press in the Crookston Daily Times. Retrieved from http://www.crookstontimes.com.

Stanton, S. \& Bazar. E. (2003a, July 3). Patriot Act foes seeking capital allies. The Sacramento Bee, B1. . (2003b, July 10). Ashcroft defends war on terrorism. The Sacramento Bee, p. B1. . (2003c, November 14). City opposes Patriot Act. The Sacramento Bee, p. B1.

Starting over in U.S. often means startups. (2007, January 21). Sacramento Business Journal. Retrieved from http://www.bizjournals.com/sacramento.

States, cities reject federal deportation program. (2011, July 22). National Public Radio. Retrieved from http://www.npr.org. 
Steers, S. (2006, May 25). Peña to fight initiative. Rocky Mountain News. Retrieved from http://www.rockymountainnews.com.

. (2007, July 7). Peña hopes session can fashion fair solution. Rocky Mountain News. Retrieved from http://www.rockymountainnews.com.

Stephan, W., \& Stephan, C. (1985). Integroup anxiety. Journal of Social Issues, 41, 157176.

Stockstill, M. (2005, December 22). Immigration laws largely unenforced in nation's interior. San Bernardino County Sun. Retrieved from http://www.sbsun.com.

Stodghill, R. \& Bower, A. (2002, Aug. 25). Welcome to America's most diverse city. Time U.S. Retrieved May 2, 2009 from http://www.time.com.

Stone, C. (1989). Regime politics: Governing Atlanta, 1946-1988. Lawrence, KS: University Press of Kansas.

. (January 2005). Looking back to look forward: Reflections on urban regime analysis. Urban Affairs Review, 40(3), 309-41.

Stroker. G. (1995). Regime theory and urban politics. In D. Judge, G. Stroker \& H. Wolman (Eds.), Theories of urban politics. Thousand Oaks, CA: Sage Publications.

$\mathrm{Su}, \mathrm{R}$. (2009, June 8). Local fragmentation as immigration regulation. Houston Law Review, 47(2), pp. 367-435.

. (2010). Immigration as urban immigration policy. Fordham Urban Law Journal, 38(1), 363-391.

Sullivan, L. (2009). Enforcing nonenforcement. California Law Review, 97(2), 567-600.

Suro, R. (2005, August 16). Attitudes toward immigrants and immigration policy: Surveys among Latinos in the U.S. and Mexico. Washington, DC: Pew Hispanic Center.

Suro, R., \& Singer, A. (2002, July). Latino growth in metropolitan America: Changing patterns, new locations. The Brookings Institution, Survey Series, Census 2000. Washington, DC: The Brookings Institution.

Suo, S., \& Chuang, A. (2001, August 6). Russians, Ukrainians call NW home. The Oregonian, p. A1. 
Sweeney, P. (2006, March 21). House sets aside cities' 'sanctuary laws.' Saint Paul Pioneer Press. Retrieved from http://www.twincities.com.

Tacoma passes resolution against Arizona's controversial immigration law. (2010, May 25). KING5 News. Retrieved from http://www.king5.com.

Tachibana, J. (1986, April 19). Capital coalition fights refugee sanctuary. The Sacramento Bee, p. B3

Takahashi, K. (n.d.). PRWORA's Immigrant Provisions [Policy analysis paper]. University of Wisconsin Green Bay.

Tambini, C. \& Sandoval II, C. (Directors and Producers). (2004). Farmingville [Documentary]. United States: POV.

Tancredo, T. (2005a, May 17). Tancredo: High noon for Denver sanctuary policy. Rocky Mountain News. Retrieved from http://www.rockymountainnews.com.

. (2005b, November 18). Rep. Tancredo to Mayor: Investigate human trafficking. U.S. Fed News. Retrieved from http://nl.newsbank.com/nl.

. (2006a). In mortal danger: The battle for America's border and security. Nashville, TN: Cumberland House Publishing, Inc.

. (2006b, October 2). Rep. Tancredo calls on Hickenlooper to stop Ritter's 'plea and release' policy. U.S. Fed News. Retrieved from http://nl.newsbank.com/nl.

. (2008, September 8). Tancredo slams Hickenlooper and Ritter for deaths by illegals [Press release] States News Service. Retrieved from http://ccir.net.

Tavernise, S. (2010, November 17). Tough law reduced immigrants, study show. The New York Times, p. A17.

Taylor, K. (1995, September 22). Immigration service raids: Are they effective or futile? The Oregonian, p. B3.

Taylor, M. (2007, December 8). Police tapped to help deport. The Sacramento Bee, p. A13.

Taylor, P. (1987, October 22). Hispanics give agenda to candidates. The Washington Post, p. A7. 
. (2001, February 2). Miami officials halt enforcement of labor-pool loitering ordinance. First Amendment Center. Retrieved from

http://www.firstamenmentcenter.org.

Thacher, D. (2005). The local role in homeland security. Law and Society Review 39, 635-76.

The People's Republic of Portland. Urbandictionary. Retrieved from http://www.urbandictionary.com.

The White House, Office of the Press Secretary. (1998, January 12). Remarks by the president in race initiative outreach [Press release], 1-24. Retrieved from http://clinton6.nara.gov.

Thermos, W. (2004, November 18). Day laborers sue Redondo Beach over stings. The Los Angeles Times. Retrieved from http://articles.latimes.com.

Thomas, R. (1994, September 13). Deputy City Manager Report: Proposition 187 denying public services to illegal immigrants, verification and reporting [Sacramento City Council agenda item 9.1], 1-13. Retrieved from http://www.cityofsacramento.org/clerk/services/index.html.

Tellis, W. (1997, July). Introduction to case study. The qualitative report [On-line serial], 3(2). Retrieved from http://www.nova.edu/ssss/QR/QR3-2/tellis1.html

Terrell, K. (1996, June 23). Immigration: Major minority issues are tossed into the political arena. The Oregonian, p. F0.

Thomas, I. (2001, Sept. 7). Flying the paranoid skies. Portland Mercury. Retrieved from http://www.portlandmercury.com.

Tilkin, D. (2008, August 18). Day labor center protestor convicted, fined $\$ 500$. KATU$T V$. Retrieved from http://www.katu.com.

Time names the five best 'big-city' mayors in America. (2005, April 17). Time [Magazine]. Retrieved from http://www.time.com.

Timeline: Important dates in Costa Mesa's decisions on illegal immigration. (2005, December 8). The Orange County Register. Retrieved from http://www.ocregister.com.

Tolbert, C. \& Hero, R. (1996). Race/ethnicity and direct democracy: An analysis of California's illegal immigrant initiative. The Journal of Politics, 58(3), 806-18. 
Tongue, K. (1997, July 3). The struggle to work. The Oregonian, p. D1.

Torres, Z. (2011, January 6). No to Arizona law in Texas. El Paso Times. Retrieved from http://www.elpasotimes.com.

Trevison, C. (2001, Nov. 29). Gresham calls for patriotism proclamation, aid to staff in military. The Oregonian, p. B2.

Tugend, T. (1999, June 23). Mass rally urges tolerance in Sacramento, The Jerusalem Post, p. 5.

Turnbull, L. \& Mayo, J. (2011, April 23). Census ranks Seattle among whitest big cities. The Seattle Times. Retrieved from http://seattletimes.com.

Turner, R. (1995). Concern for gender in central-city development policy. In J. Garber (Ed.). Gender and urban research (pp. 271-89). Thousand Oaks, CA: Sage.

Turque, B. (2007, January 18). Herndon anti-solicitation law challenged. The Washington Post, p. B1.

Turque, B., \& Stewart, N. (2006, May 3). Labor site backlash felt at polls in Herndon. The Washington Post. Retrieved from http://www.washingtonpost.com.

Two billboards join Colorado debate on illegal aliens. (2006, June 1). The Washington Times. Retrieved from http://www.washingtontimes.com.

Two California cities boycott Arizona over immigration law [Blog]. (2010, May 5). L.A. Now, Los Angeles Times on the Web. Retrieved at http://latimesblogs.latimes.com.

Two wrong-headed boycotts wouldn't make a right [Editorial]. (1994, November 12). The Denver Post, p. B7.

Twohy, P. (2011, June 9). Study: Immigrants are better educated. Sacramento Business Journal. Retrieved from http://www.bizjournals.com/sacramento.

Tzfadia, E. (2005). Local autonomy and immigration: Mayoral policy-making in peripheral towns in Israel. Space \& Polity 9(2), 167-183.

United States Citizenship and Immigration Service (USCIS), Office of Policy and Strategy. (2004). Citizenship in the United States. Washington, DC: Author. Retrieved from http://www.uscis.gov. 
U.S. Census Bureau. (2003). Migration and geographic mobility in metropolitan and non-metropolitan America: 1995-2000. Washington, DC: Author. Retrieved from http://www.census.gov.

U.S. Census Bureau, 2010 Census. Denver. Washington, DC: U.S. Census Bureau. . Portland. Washington, DC: U.S. Census Bureau. . Sacramento. Washington, DC: U.S. Census Bureau.

U.S. Census Bureau, 2000 Census. Denver. Washington, DC: U.S. Census Bureau. . Portland. Washington, DC: U.S. Census Bureau. . Sacramento. Washington, DC: U.S. Census Bureau.

U.S. Census Bureau, 1990 Census. Denver. Washington, DC: U.S. Census Bureau. . Portland. Washington, DC: U.S. Census Bureau. . Sacramento. Washington, Dc: U.S. Census Bureau.

U.S. Census Bureau, 1980 Census. Denver. Washington, DC: U.S. Census Bureau. . Portland. Washington, DC: U.S. Census Bureau. . Sacramento. Washington, DC: U.S. Census Bureau.

U.S. Census Bureau. Mapping Census 2000: The Geography of U.S. Diversity. Washington, DC: Author. Retrieved from http://www.census.gov.

U.S. Conference of Mayors, Criminal and Social Justice Committee. Resolutions adopted at the U.S. Conference of Mayors $76^{\text {th }}$ Annual Meeting, June 20-24, 2008, Miami. Retrieved from http://preview.usmayors.org.

U. S. Department of Justice, Eastern District of California. (n.d.) The Greater Sacramento Area Hate Crimes Task Force. Sacramento, CA: United States Attorney's Office. Retrieved from http://www.justice.gov/usao/cae/hatecrimes.html.

U. S. Department of Justice, Bureau of Justice Assistance. (n.d.) Stopping hate crime: A case history from the Sacramento Police Department [Fact sheet]. Retrieved from http://www.ojp.usdoj.gov/BJA. 
U.S. Immigration and Customs Enforcement. (2006, November 28). ICE and Costa Mesa announce pact to identify deportable aliens [Press release]. Retrieved from http://www.ice.gov.

. U.S. Immigration and Customs Enforcement. (2007, September 24). Delegation of Immigration authority Section 287(g) Immigration and Nationality Act [Fact sheet]. Retrieved from http://www.ice.gov.

. (2008, April 28). Partners: Law enforcement. Retrieved from http://www.ice.gov.

. (n.d.). ICE Access. Retrieved from http://www.ice.gov.

. (n.d.). Ice Operation Return to Sender yields 178 arrests in South Florida. Inside ICE, 4(2). Retrieved from http://www.ice.gov.

U.S. Immigration Support. (2009, November). Police leaders call for immigration reform. United States Immigration Newsletter. New York, NY: Author. Retrieved from http://www.usimmigrationnews.org.

. (n.d.). Immigration amnesty for illegal immigrants. Retrieved from http://www.usimmigrationsupport.org/amnesty-illegal-immigrants.html.

Valenty, R. (2006, January 15). Council to talk wage theft. Colorado Daily. Retrieved from http://www.coloradodaily.com.

Valenzuela, A., Jr. (2000). Controlling day labor: Government, community and worker responses. In D. Mitchell \& P. Normura (Eds.), California Policy Options 2001. Los Angeles, CA: UCLA Anderson Business Forecast and School of Public Policy and Social Research.

. (2003). Day labor work. Annual Review of Sociology 29, 307-33.

Valenzuela, A., Jr., Theodore, N., Meléndez, E., \& González, A. L. (2006). On the corner: Day labor in the United States. Los Angeles, CA: Center for the Study of Urban Poverty, University of California, Los Angeles.

Varsanyi, M. (2005). The Paradox of contemporary immigrant political mobilization: Organized labor, undocumented migrants, and electoral participation in Los Angeles. Antipode, 37(4), 775-795.

. (2006a, May). Interrogating 'Urban Citizenship' vis-á-vis undocumented migration. Citizenship Studies, 10(2), pp. 224-244. 
. (2006b, June). Rising tensions between national and local immigration and citizenship policy: Matrículas Consulares, local membership and documenting the undocumented [Working paper No. 140]. University of California-San Diego: Centre for Comparative Immigration Studies.

. (2007). Documenting undocumented immigrants, Geopolitics 12(2), 299-319.

. (2008). Immigration policing through the backdoor: City ordinances, the "right to the city," and the exclusion of undocumented day laborers [Working paper 165]. University of California-San Diego: Centre for Comparative Immigration Studies.

. (2010).City ordinances as 'immigration policing proxy:' Local governments and the regulation of undocumented day laborers. In M. Varsanyi (Ed.), Taking local control (pp. 135-56). Stanford, CA: Stanford University Press.

. (2011). Neoliberalism and nativism: Local anti-immigrant policy activism and an emerging politics of scale. International Journal of Urban and Regional Research, 35(2), 295-311.

Varsanyi, M., Lewis, P., Provine, D., \& Decker, S. (2012, April). A multilayered jurisdictional patchwork: Immigration federalism in the United States. Law \& Policy, 34(2), 138-158.

Vasquez, S. (1994, June 20). Denver targeted as site for major Hispanic conventions. The Rocky Mountain News, p. 10N.

Vaughan, J. M. (2009, December). Chronic backlogs at USCIS show agency is not ready for CIR-ASAP. Washington, DC: Center for Immigration Studies. Retrieved from http://www.cis.org.

Verhovek, H. (2000, September 20). Oregon immigration official resigns amid furor. The New York Times. Retrieved from http://www.nytimes.com.

Vigil, K. (2002, December 30). Nebraska group's threat over Mexican ID cards doesn't ruffle Pueblo, Colo. The Pueblo Chieftain. Retrieved from http://nl.newsbank.com.

Villa, J. (2008, October 18). Tancredo-Denver rematch: Politician renews 'sanctuary' charge, city denies it. Rocky Mountain News. Retrieved from http://nl.newsbank.com

VisonPDX. (2007, October). Community engagement report. Retrieved from http://www.visionpdx.com. 
. (2013). About visionPDX: Portland's Community Visioning Project. Retrieved from http://www.visionpdx.com.

Vitello, P. (2005, October 6). As illegal workers hit suburbs, politicians scramble to respond. The New York Times, p. A1.

. (2006, December 16). Rift over illegal immigration leads to talks of secession. The New York Times. Retrieved from http://www.nytimes.com.

Vogel, N. (2003, April 29). Mexican Id card measure goes to Senate. The Los Angeles Times. Retrieved from http://articles.latimes.com.

Vote 'no' on car seizure plan Initiative 100 on the Aug. 12 [Editorial]. (2008, August 1). The Denver Post, p. B10.

VOZ Worker's Rights Education Project. (2008, March 11). Day labor center a historic victory! Retrieved from http://www.portlandvoz.org. . (n.d.) History. Retrieved from http://www.portlandvoz.org.

Wadhwa, V. (2010, Jan. 24). Bringing the Silicon Valley to Sacramento. Tech Crunch. Retrieved from http://techcrunch.com.

Wahid, Z., \& Taxin, A. (2005, December 8). Focus on offenders. The Orange County Register. Retrieved from http://www.ocregister.com/ocregister.

Wallace, L. (2001). El Jornalero: El Hereo: The Work and Community of Journaleros in Portland, Oregon [Unpublished thesis]. Lewis \& Clark College, Portland, Oregon.

Wallace, M., \& Frisken, F. (2000). City-suburban differences in government responses to immigration in the Greater Toronto Area [Research paper 197]. Toronto: Centre for Urban and Community Studies, University of Toronto.

Walsh, E. (2008, July 4). Activists' ideas dominate ballot. The Oregonian, p. A8.

Walsh, J. (2005, Spring). Sanctuary cities and states: Undermining the American Republic. The Social Contract. Retrieved from http://www.thesocialcontract.com.

Walsh, M. (2003). Immigration enforcement by local police [Issue brief No. 9]. Washington, DC: National Council of La Raza. . (2007). Immigration enforcement by local and state police: The impact on Latinos. Law Enforcement Executive Forum 7, 15-32. 
Waslin, M. (2010). Immigration enforcement by state and local police: The impact on the enforcers and their communities. In M. Varsany (Ed.), Taking local control (pp. 97-114). Stanford, CA: Stanford University Press.

Weaver, H. (1999, December 20). Sacramento's special hodgepodge. The Sacramento Bee, p. B7.

Webb, W. (1998, March 7). Mayor Wellington Webb's remarks introducing Executive Order 116 [Immigration press conference]. Retrieved from http://m.rockymountainnews.com.

Wells, M. J. (2004, Winter). The grassroots reconfiguration of U.S. immigration policy. International Migration Review, 38(4), 1308-1347.

Whelan, R., Young, A. \& Lauria, M. (1994). Urban regimes and racial politics in New Orleans. Journal of Urban Affairs 16, 1-21.

Willens, K. (2005, August 4). Illegal immigrants clash with local on Long Island. USA Today. Retrieved from www.usatoday.com.

Wilson, J., Singer, A., \& DeRenzis, B. (2010). Growing pains: Local response to recent immigration settlement in suburban Washington, DC. In M. Varsanyi (Ed.), Taking local control (pp. 193-218). Stanford, CA: Stanford University Press.

Wilson, W. (1986, October 14). Courts ease INS curbs on illegal aliens. Sacramento Bee, p. B1.

Wilson, W. \& Singer, A. (2007). Refugee resettlement in Metropolitan American Washington, DC: The Brookings Institute. Retrieved from http://www.migrationinformation.org.

Wimmer, L. (2008, September 22). City investigating day labor center alternatives. Fort Worth Business Press. Retrieved from http://wwwfwbusinesspress.com.

Win-win solution: Mayor's pledge to keep day labor center open will preserve a needed community resource [Editorial]. (2007, June 24). The Houston Chronicle, Outlook, p. 2.

Wolf, J. \& Vanderveen, C. (2007, June 5). Day labor site must close, city says. 9News. Retrieved from http://www.9news.com.

Workplace Fairness. (2013). Undocumented workers. Washington, DC: Author. Retrieved from http://www.workplacefairness.org. 
Wozniacka, G. (2008, June 26). City Hall opens its doors to immigrants. The Oregonian, InPortland, p. 6.

Wright, M., \& Herron, C. R. (1985, December 29). The nation: A haven for Central Americans. The New York Times, p. 4-4.

Zapler, M. (1996, December 16). Webb in Washington for release of report on hunger. States News Service. Retrieved from http://nl.newsbank.com.

Zellerbach Family Foundation. (2007, January). Bay Area day labor programs. San Francisco, CA: Yolanda Alindor.

Yasui, L., Ruckelshaus, C., \& Sugimori, A. (2004, February). Drafting day labor legislation: A guide for organizers and advocates. New York, NY: National Employment Law Project.

Yin, R. (1993). Applications of case study research. Beverly Hills, CA: Sage Publishing. (1994). Case study research: Design and methods (2nd ed.). Beverly Hills, CA: Sage Publishing.

. 2003. Case study research: Design and methods (3rd ed.) Thousand Oaks, CA: Sage Publications.

York, B. (2010, November 28). Politically correct Portland rejected feds who saved city from terrorist attack. The Washington Examiner. http://washingtonexaminer.com.

Yost, W. (1994, December 29). Councilwomen seeks own pace. The Sacramento Bee, p. N1.

Zamora, J. (2007, April 25). Oakland resolutions condemn federal immigration raids. The San Francisco Chronicle. Retrieved from http://www.sfgate.com. 
APPENDIX A 


\section{A Checklist of Potential Municipal Unauthorized Immigration Strategies}

1. Lawmaking (legal and extralegal). Local government (mayor or city council) might use its legislative authority to formulate new policies pertaining to immigration issues, or amend or rescind existing policies. These policies may be general or specific to a particular government agency or department, and take the form of an executive order, administrative law, statue, code, ordinance, resolution, license, permit, or memorandum.

2. Law enforcement. Municipal authorities might use their regulatory and police powers to actively enforce existing municipal laws that were not originally intended to address immigration-related issues, but have that effect. In practice this may involve charging police, or other municipal employees (e.g., building inspectors and social workers), with enforcement of previously unenforced rules and regulations governing sanitation, health, housing, transportation, and labor standards (Light, 2006). A local government might also choose to turn a "blind eye" to local or even federal law violations. In some cases, municipal employees may be required to enforce federal immigration laws, or a local version of the same.

3. Legal opinions. Local authorities might use legal opinions to support their position on immigration or foreign in-migrants.

4. Finance appropriation. City officials might use their investment powers to directly or indirectly provide monetary grants or in-kind contributions (e.g., 
facility space) to support immigrants, or withhold public investments from the same.

5. Provision of public benefits. Local government might use its fiscal discretionary power (i.e., power to use public revenues) to either guarantee or deny foreign inmigrants equitable access to: job services; public parks, libraries and schools; police and fire protection; health and emergency services; housing and transportation; water and waste disposal.

6. Property policy management. A municipality might use its property clout to purchase, hold, condemn, lease, sell, or manage a property for the purpose of advancing or hindering the interests of foreign nationals.

7. Public works authority. City authorities might use their say-so over the construction and operation of public works (i.e., public facilities like hospitals, schools, libraries, parks) to help or hinder its new foreign-born residents.

8. Land use and urban planning. City bureaucrats might use their expertise to plan for the physical and social development of a city in a way that serves the interests of foreign in-migrants, or hinders these newcomers.

9. City strategic planning. To attract foreign investors or needed laborers, a municipality may develop a blueprint to advance its vision of becoming more internationally-oriented (e.g. Cleveland's internationalization plan). A local government might also develop a strategy for ridding the city of unwanted foreign in-migrants. 
10. Community image building. Local government might chose to use its city branding clout to create a welcoming or unwelcoming settlement environment for foreign in-migrants. In practice this may involve the use of officially or unofficially sanctioned symbols (billboards, flags, or logos), city value statements or mottos, and so on.

11. Municipal human resource oversight. Local officials might use their control over city human resources to establish personnel systems-like selection, promotion, salary standards--that benefit or disadvantage foreign in-migrants.

12. Corporate policy control. Local government might use its contract and litigation power in a manner that either benefits or disadvantages foreign in-migrants.

13. Lobbying. A city official might use his or her lobbying privileges to persuade representatives in the national or state legislature, or courts, to support their policy preferences or position on immigration.

14. Coalition Building. To enhance its capacity to achieve immigration-related policy objectives, a local government might build cooperative alliances with public officials in other cities or states. It might also facilitate the development of publicprivate partnerships, or even partner with federal immigration authorities.

15. Public relations. A city official might use his or her position of prominence as a platform for informing the public about immigrant-related issues and resources, or to shape public opinion in accordance with the city's immigration agenda. In practice this may involve: launching a public education or advocacy campaign, issuing public service announcements, publishing information on the city's 
website, sending a press release to the media, staging a news conference or signing ceremony, writing and submitting an opinion piece in a local newspaper, distributing a press kit, making a presentation to a civic group, delivering a State of the City address, disseminating research reports that bolster a city's position on immigration, writing a letter to the president of the United States or Congress, or testifying for governmental hearings and regulatory bodies.

16. Political participation planning. City officials might use their political appointment and meeting convening authority to establish mechanisms for incorporating the concerns of foreign in-migrants into government decisionmaking. Or conversely, municipal authorities might refuse to support the public participation of refugees and immigrants. In practice this may involve: appointing foreign-born residents to public commissions, advisory groups and tasks forces (or excluding them from the same); allowing noncitizens to vote in local elections, or not; or holding meetings, public hearings, and workshops to get policy feedback from foreign in-migrants (as opposed to establishing a discussion process that only elicits feedback from natives, or does not provide language access to non-English speakers).

17. Civic mediation. Local government might use its community planning process to diffuse immigration-related civic disputes or facilitate collaborative problemsolving. In practice this might involve providing a venue and discussion facilitator. A municipality might also hire an outside professional to design a 
discussion process, or assign a police officer to act as a liaison between contending community groups.

18. Ballot box crusades. Elected officials might refer to voters a pro- or antiimmigrant measure, or campaign on a pro- or anti-immigration platform.

19. Protests. Municipalities might instigate direct protest actions to call attention to insufficient immigration assistance from the federal government. Halting construction of a federal mandated public housing project for immigrants is an example.

20. Civic membership. City officials might use their jurisdictional authority to decide who is considered a legitimate community member. In practice this may involve issuing municipal identification cards to federally unauthorized city dwellers, or accepting an ID card issued by a foreign government. ${ }^{312}$ It might also entail efforts to deflect unwanted refugees and immigrants to other cities, through use of no trespassing laws or other unfriendly ordinances.

21. Taking no action. A municipality might also decide to do nothing when immigration-related issues arise locally. There are a number of plausible reasons for this laissez-faire approach: indifference or ambivalence towards immigration and foreign in-migrants; local government lacks the capacity to act on its policy decisions; or the issue has already been addressed by a higher level of government or by community-based agency.

312 These ID cards typically extend to holders the rights and benefits of citizenship, including access to government services. 
APPENDIX B

332 
Table 1.1 Typology of municipal unauthorized immigration policy by domain and issue area (asylum for unauthorized refugees)

$$
\text { ISSUE: ASYLUM FOR UNAUTHORIZED REFUGEES }
$$

Policy Responsive Somewhat Responsive

Types

Domain: Legal-Political

Issue Areas:

Protest

Federal

Policy

\&

Political

Membership
Local government petitions Congress for nondiscriminatory compliance with refugee policy and suspension of deportations pending investigation. ${ }^{313}$

City council adopts a nonbinding "City or Refuge" resolution declaring its jurisdiction a safe haven for specific groups of unauthorized refugees, ${ }^{314}$ or all persons unjustly denied refugee status (Seattle, WA), and pledging to protect asylees, and humanitarians offering them assistance, from deportation by limiting city cooperation with the INS. ${ }^{315}$
Establish Sister City relationship with the home nation of refugees/alysees denied protection by the U.S. federal government as an indirect way to protest uneven application of U.S. refugee policy (Berkeley, CA).

Establish citizen commission to study becoming a "sanctuary city"; asylum seekers incorporated into the deliberation process (Seattle, WA).

Local government takes no stand on the U.S. refugee policy debate, because a "sanctuary" policy was already adopted at the state level (e.g., cities in New York and New Mexico).
City officials take no stand on the federal refugee policy debate, because they want to prevent a flood of unwanted refugees from settling in their jurisdictions, or because they are oblivious to the plight of asylum seekers.

Local government repeals a declaration of sanctuary to stem the tide of unauthorized refugees into the city ( $L o s$ Angeles, $C A)$, or after challenging a federal law in court and losing (New York).

\footnotetext{
${ }^{313}$ Berkeley, CA; San Francisco, CA; Chicago, IL; Cambridge, MA.

${ }^{314}$ Berkeley, CA; Davis, CA; Los Angeles, CA; Oakland, CA; Sacramento, CA; San Francisco, CA; San Jose, CA; Santa Barbara, CA; Santa Cruz, CA; West Hollywood, CA; Boulder, CO; Chicago, IL; Takoma Park, MD; Bookline, MA; Cambridge, MA; Sommerville, MA; Detroit, MI; East Lansing, MI; Duluth, MN; Minneapolis, MN; St. Paul, MN; Fargo, ND; Santa Fe, NM; Ithaca, NY; Rochester, NY; Swarthmore, PA; Burlington, VT; Olympia, WA; Seattle, WA; and Madison, WI (Bau, 1994; Hobbs, 1994).

${ }^{315}$ While the language contained in the resolutions differs somewhat, most proclamations discouraged municipal employees, including police, from gathering or disseminating information on the citizenship status of city residents, or otherwise cooperating in the investigation of civil immigration violations.
} 
Table 2.1 Typology of municipal unauthorized immigration policy by domain and issue area (unregulated day laborer-contractor market exchange) ISSUE: UNREGULATED DAY LABORER (DL)-CONTRACTOR MARKET EXCHANGE

\section{Policy}

Types

Responsive

\section{Unresponsive}

Domains: Spatial, Socio-Economic \& Legal-Political (overlapping)

Issue Areas:

Public

Space/

Labor

Market/

Policing

No municipal restrictions on solicitation at informal job hiring sites; DLs freely solicit work on public streets and sidewalks in accordance with their constitutional rights (New York, NY; Graton, CA; Seattle, WA).

No municipal restrictions on loitering exist; DLs are allowed to stand on the sidewalk while waiting for work
Limited anti-solicitation enforcement; police only ticket motorists who stop to pick up day laborers in the street, but they do not stop anyone who pulls into nearby parking lots (Concord, CA). ${ }^{316}$

To appease local businesses, police temporarily scatter crowds of day laborers with no intent to prosecute; workers return quickly.

Police department assigns a fulltime patrol officer to civic dispute mediation duty;

officer acts as a liaison between stakeholders involved in the DL land use dispute (Herndon, VA).

A police department forms a separate unit to manage public space disputes between DLs and oppositional neighbors

(Glendale, CA).

Police responds to complaints made by or about workers seeking day labor by shifting responsibility to another level of government or NGO, e.g., bilingual legal aid services (San Francisco, CA), state labor relations, or federal immigration law enforcement.
Elected officials enact a "blanket" antisolicitation ordinance (that criminalizes DL solicitation everywhere within the city), or a limited solicitation law imposing time, place and manner restrictions on DL soliciting on public property (Herndon, VA; Marietta, GA).

Local government adopts a DL-specific anti-loitering ordinance making loitering to obtain a job a crime $($ Miami, $F L){ }^{317}$

Elected officials pass a citywide no-trespassing law regulating DL solicitation on private property (Lake Forest, $C A$ ).

Police selectively enforce a state notrespass law arresting suspected unauthorized DLs and charging them with trespassing into the U.S. (New Ipwsich \& Hudson NH; Brewster, NY).

\footnotetext{
${ }_{317}^{316}$ Day labor (DL) program staff said police enforcement of the ordinance is fair and supportive of day workers' interests (Alindor, 2007).

${ }^{317}$ These unevenly applied codes have been dubbed "Standing While Latino" laws since day laborers are overwhelmingly Latino.
} 
Table 2.2 Typology of municipal unauthorized immigration policy by domain and issue area (unregulated day laborer-contractor market exchange) ISSUE: UNREGULATED DAY LABORER (DL)-CONTRACTOR MARKET EXCHANGE

Policy

Types

Responsive

Somewhat Responsive

Domains: Socio-Economic \& Legal-Political (overlapping)

Issue Areas:

Labor

Market/

Policing

Police enforce existing zoning and lands use codes not originally intended to restrict DL activity but has that effect, e.g., anti-solicitation laws against newspaper hawkers (Carlsbad, CA) or prostitution.

Police enforce existing laws targeting offenses associated with DL sites, rather than regulating the act of solicitation itself (e.g., trespassing, loitering, public intoxication, jaywalking, littering and vandalism activity).

City council enacts a minor crimes initiative that allows police to crack down on DL activity by charging suspects with minor crimes, like riding a bicycle without a bell or sitting on a milk crate in the city limits (Miami, FL).

Uniformed police establish a highly visible, intimidating presence near areas where DLs congregate as part of a deliberate and coordinated campaign to drive them off the streets (Mamaroneck, $N Y$ ) 
Table 2.3 Typology of municipal unauthorized immigration policy by domain and issue area (unregulated day laborer-contractor market exchange) ISSUE: UNREGULATED DAY LABORER (DL)-CONTRACTOR MARKET EXCHANGE

Policy

Types

Responsive

\section{Somewhat Responsive}

Domains: Spatial, Socio-Economic \& Legal-Political (overlapping)

Issue Areas:

Public

Space/

Labor

Market/

Policing

Town council amends a local harassment ordinance to make it illegal to follow someone in or about a public space with the intent of harassing, annoying or alarming (Carbondale).

City council prohibits independent police deportation sweeps, and calls on federal agents to clearly state they are not local

police (Richmond, CA).
Local government enacts a resolution or issues a statement of opposition to the Minutemen, and groups like them, that harass DL at job sites (San Francisco, CA; Austin, TX).

\section{Unresponsive}

Undercover police posing as contractors seeking to hire workers arrest DLs for violating traffic control measures (Redondo Beach, CA).

Police conduct a large-scale, INS-style arrest campaign targeting suspected illegal immigrants at DL sites; workers without ID cards are detained for arrest by ICE or Border Patrol agents (Riverside, CA; Mesa, AZ).

Police chief refuses to sign antiharassment agreement drafted by migrant day laborers and their advocates (Portland, Oregon).

City authorities take no action to curb harassment and intimidation of DLs by anti-illegal immigrant citizen brigades at job sites (Vista City, CA).

Police officers harass potential employers by reporting the license numbers of vehicles seen picking up DLs to federal immigration authorities, the IRS, and State Department of Labor (East Hampton Village, $N Y$ ). 
Table 2.4 Typology of municipal unauthorized immigration policy by domain and issue area (unregulated day laborer-contractor market exchange) ISSUE: UNREGULATED DAY LABORER (DL)-CONTRACTOR MARKET EXCHANGE

\section{Policy}

Types

Responsive

Somewhat Responsive

\section{Unresponsive}

Domains: Socio-Economic \& Legal-Political (overlapping)

Issue Areas:

Labor

Market/

Policing

City officials ignore local employer

infractions of federal laws prohibiting the

hiring of unauthorized immigrants, to

protect the free speech and equal

protection rights of employers who hire

DLs.

City council passes an ordinance that criminalizes day labor wage theft (Kansas

City, MO; San Francisco, CA; Seattle,

WA; Phoenix, AZ). ${ }^{318}$

City enforces the criminal provisions of state theft of services wage laws through the police department. (New Haven, CT; Austin, TX).
Public works personnel sets up a noparking zone at informal DL gathering site, so police can fine employers who stop under a state parking law (Riverside, CA; Chandler, AZ).

Public works personnel block access to the ad hoc DL gathering site with temporary fencing and/or adjust traffic signals for higher volume of pedestrian traffic through crosswalks, or by moving a nearby bus stop, to reduce loitering (Herndon, VA).

City council passes a resolution declaring its disapproval of city contractors who use illegal immigrants (Tulsa, OK).

Local officials adopt an ordinance requiring contractors to employ minimum numbers of native-born residents on city construction projects (Boston, MA; Chicago, IL).

\footnotetext{
${ }^{318}$ These amendments to municipal petty theft code supplement state law by covering cases for lesser amounts than prosecutable at the state level;
} most day laborers, who most often are owned less than $\$ 500$, were left out of the loop. 
Table 2.5 Typology of municipal unauthorized immigration policy by domain and issue area (unregulated day laborer-contractor market exchange) ISSUE: UNREGULATED DAY LABORER (DL)-CONTRACTOR MARKET EXCHANGE

\section{Policy}

Types

\section{Responsive}

Somewhat Responsive

Domains: Spatial \& Socio-Economic (overlapping)

Issue Areas:

Housing/ Local government adopts ordinance

Labor establishing housing for DLs (Graton,

Market $\quad C A)$.

City does not enforce anti-crowding codes.
City denies permits and contracts to businesses that hire unauthorized immigrants (Bernadino, CA).

Local government passes an employer registration ordinance requiring employers, or agents who hire DLs off the street, to register with the city, display permits in their car windows, and present workers with written terms of employment (Vista City, CA). ${ }^{319}$

Local officials initiate a moratorium on apartment construction (only big lot single family houses are allowed), forcing DLs to share housing (Santa Ana, CA).

City council passes a strict anti-crowding ordinance reducing the number of housing occupants above the state standard (Santa Ana, CA), or changes the definition of "family" in city code so households are restricted to immediate family members.

\footnotetext{
${ }^{319}$ Since workers did not request these protections, and the names of registrants are public record and easily accessible by anti-immigrant activists, day labor advocates contend the ordinance is an attempt to break up local day labor sites under the guise of protecting workers from unscrupulous contractors. They argue that mandatory employer registration hurts workers by discouraging contractors and homeowners from hiring (Rodrigues \& Gaona, 2006)
} 
Table 2.6 Typology of municipal unauthorized immigration policy by domain and issue area (unregulated day laborer-contractor market exchange) ISSUE: UNREGULATED DAY LABORER (DL)-CONTRACTOR MARKET EXCHANGE

Policy

Types

Responsive

Somewhat Responsive

Domains: Spatial \& Socio-Economic (overlapping)

Issue Areas:

Public

Space/

Housing/

Labor

Market

City officials vote down a proposed comprehensive anti-illegal immigrant ordinance that would have prohibited DLs from soliciting work, punished businesses that hired unauthorized day workers, and mandated that official city business be in English only (San Bernardino, CA)
Local government adopts new housing codes forbidding use of rooms other than bedrooms for sleeping, or limiting the square footage of driveways.

Mayor 'beefs up' inspections of properties where DL "stacking" is suspected; inspectors issue citations after counting cars parked in front of houses (Danbury, CT), looking for violations of local landscaping ordinances (Palmdale, $C A)$, or by monitoring water use to identify the practice (Brewster, $N Y$ ).

City prosecutes slum lords without replacing lost dilapidated tenements with affordable housing, deflecting DLs to cities that do not sanction for illegal housing (Los Angeles, CA).

City council adopts an ordinance that imposes penalties on employers who give illegal DLs jobs and landlords who rent to them (Hazleton, PA; Valley Park, MO;

Escondido, CA; Farmers Branch, TX; Fremont, NE). ${ }^{320}$

\footnotetext{
${ }^{320}$ The Farmers Branch ordinance was approved by voters and also requires city residents to 'register' and obtain an 'occupancy license.'
} 
Table 2.7 Typology of municipal unauthorized immigration policy by domain and issue area (unregulated day laborer-contractor market exchange) ISSUE: UNREGULATED DAY LABORER (DL)-CONTRACTOR MARKET EXCHANGE

\section{Policy Types}

Responsive

Somewhat Responsive

Domains: Legal-Political \& Socio-Economic (overlapping)

Issue Areas:

Political

City officials provide community

Participation/ planning support for stakeholders

Labor working on a win-win solution to a local

Market day labor problem; day laborers are

included in the problem identification and

resolution process (Portland, OR). ${ }^{321}$
Elected officials organize a regional summit or forum to bring together experts to discuss an area-wide response to the DL phenomenon (Phoenix, AZ). ${ }^{322}$

City officials appoint a temporary commission or task force to oversee research on the local DL-contractor market exchange problem and investigate policy options; DLs are included in the appointed advisory group (Mesa, AZ; Gaithersburg, MD; New York, NY; Austin, TX).

Local government hires an external expert to study the local DL dilemma (including interviewing DLs), evaluate DL center models in other jurisdictions, and design a process for discussing alternative solutions (Berkeley, CA; Mesa, AZ; Queen Creek, AZ).
Unresponsive

City officials convene a public hearing or town meeting to get public feedback on a proposed formal day labor site; DL are not included (Farmingville, $N J$ ).

Local government provides community planning support for stakeholders working to get rid the city of unwanted DLs; solutions discussed benefit nativeborn community members only, and DLs are excluded from the decision-making process.

${ }^{321}$ Community planning support includes a discussion venue, meeting facilitator, staff support for research, a policymaker and possible translation services.

${ }^{322} \mathrm{COG}$ is a nonprofit association comprised of 21 local governments surrounding out nation's capital, plus area members of the Maryland and Virginia legislatures, the U.S. Senate, and the U.S. House of Representatives. 
Table 2.8 Typology of municipal unauthorized immigration policy by domain and issue area (unregulated day laborer-contractor market exchange) ISSUE: UNREGULATED DAY LABORER (DL)-CONTRACTOR MARKET EXCHANGE

\section{Policy}

Types

Responsive

Somewhat Responsive

Domains: Spatial \& Socio-Economic (overlapping) Issue Areas:

Land use/ Local government purchases, leases or Labor condemns public property to secure a

Market good location for a formal DL hiring site (Houston, TX; Laguna Beach, CA)

City planning commission or zoning board authorizes conditional or special use permits that allow a NGO to open and operate a DL hiring site in an area previously off-limits (Portland, OR).

City council amends municipal code to encourage the location of DL hiring sites in an area conveniently located for employers and DLs.

City attorney offers free legal advice to a private property owner willing to donate or lease space for a city-sanctioned DL center.
City council adopts a conditional use permit that makes approval of a new Home Depot store contingent upon the retailer's agreement to construct and maintain a DL facility onsite (Burbank, $C A)$.

City council adopts an ordinance amending municipal code to create a conditional use permit process and DL operating standards for home improvement chains seeking to renovate their big-box stores (Los Angeles, CA).

City issues a conditional use permit for a city-sanctioned DL center that forbids the provision of services other than job matching and ESOL classes onsite (Herndon, VA).

City officials convene a community forum or town meeting to overcome NIMBY opposition and facilitate successful adoption of a planned DL job site.

\section{Unresponsive}

City council passes an ordinance prohibiting the use of public property for a DL center.

City planning commission or zoning board turns down a special use permit request blocking a proposed DL hiring site.

Local officials adopt an ordinance authorizing the location of a formal DL site in an area that pleases local residents and business owners, but is out of the way for employers and hard for DLs to get there (Glendale, CA; Fort Worth, TX)

City adopts an ordinance requiring local businesses that want to allow DLs, and those who employ them, to congregate on their property to apply for a permit;

violators are penalized with a fine or jail (Orange, CA). 
Table 2.9 Typology of municipal unauthorized immigration policy by domain and issue area (unregulated day laborer-contractor market exchange) ISSUE: UNREGULATED DAY LABORER (DL)-CONTRACTOR MARKET EXCHANGE

\section{Policy}

Types

Responsive

Domain: Socio-Economic

Issue Areas:

Labor

Market

Vendor activity at DL hiring sites is permitted; city officials enforce existing civil liberty protections that guarantee DLs opportunities to sell goods in public areas (Portland, OR).

Local government solicits help from area merchants to provide materials and/or financial assistance in building a DL center (Glendale, $C A$ )

City council provides monetary grants or in-kind contributions to a DL center developed and run by a NGO (Denver, CO; Portland, OR).

City council adopts an ordinance approving the use of public funds to set up a formal DL center (Los Angeles, CA; San Francisco, CA; Houston, TX), or funds a

DL program that operates on the street (Berkeley, $C A) .{ }^{323}$

\section{Somewhat Responsive}

Public works personnel improves organization at an existing informal DL gathering site by installing a 4-way sign to slow traffic down, posting rules for DLs and employers to follow, placing trash containers and portable restrooms onsite, or providing seating and shelter to protect workers from the elements (Berkeley, CA).

City council and/or community advisory board enacts a resolution in favor of a community-funded and run DL center; this show of support lends legitimacy to the project, but little else.

\section{Unresponsive}

Local government denies DL-vendors access to public space to sell goods, or authorities amend city contracts requiring vendors to certify that they do not employ unauthorized workers and hire code

enforcement officers conduct spot checks (Santa Clarita, CA).

City council and/or community advisory board enacts a resolution opposing a community-funded and run DL center.

City council adopts an ordinance prohibiting the use of taxpayer money to establish or run a DL center, or votes to defeat a proposal for a the same (San Rafael, CA; Farmingville, NJ).

City withdraws approval for public money to fund a DL center, after constituents threaten officials with their jobs (Suffolk County, NY), or the following year authorities delete funding for a DL center from the municipal budget (Houston, TX).

\footnotetext{
${ }^{323}$ Fund sources: the city's general fund, the mayor's budget (e.g., the Mayor's Office on Immigration and Refugee Affairs), or the city's
} Economic and Community Development Department funds, which come from federal Block grant money. 
Table 2.10 Typology of municipal unauthorized immigration policy by domain and issue area (unregulated DL-contractor market exchanges) ISSUE: UNREGULATED DAY LABORER (DL)-CONTRACTOR MARKET EXCHANGE

\section{Policy}

Types

Responsive

Domain: Socio-Economic

Issue Areas:

Labor

Market

Mayor and/or city council members solicit donations from individuals and businesses to keep a day labor center afloat, usually after city funding is discontinued or before it starts (Houston, TX; Denver, CO).

City government promotes a local DL hiring site by proving information about day laborer resources on their websites (Chandler, AZ; Los Angeles, CA; Plano, $T X)$.

City-funded DL center allows unrestricted access (either implicitly or explicitly) to immigrants regardless of citizenship; staff does not check the immigration status of workers (Plano, TX).

Local government establishes supplemental programs at DL hiring centers.

\section{Somewhat Responsive}

\section{Unresponsive}

Municipal officials shuts down taxpayersubsidized DL center due to litigation (Herndon, VA), budget woes (Austin, TX), lack of DL use (El Monte, $C A ;$ El Monte, $C A$ ), liability issues (Laguna Beach, $C A$ ), location zoning code conflicts (Chicago, $I L)$, a change in political leadership (Passaic, NY), to make way for a community revitalization project (Huntington Town, RI), or anti-illegal immigrant protests (Costa Mesa, CA).

City's ordinance to fund DL center requires people seeking employment to fill out a federal eligibility form; but the law is not enforced (Houston, TX).

Do nothing: the DL issue has already been addressed at that state or county level; a suburb is using the resources of a nearby city; or local constituents have a high threshold of tolerance for day labor activity (New York).
City-funded DL center required to post eligibility requirements stating job services are restricted to U.S. citizens and permanent residents (Garland, $T X$ ); workers who use a city-run center are be able to provide proof of illegal status (e.g., a federal I-9 form) (Orange, $C A)$.

Do nothing, because local government lacks understanding of the issue, or the community is so divided over the day labor debate that no resolution will work. required to present two forms of ID and 
Table 3.1 Typology of municipal unauthorized immigration policy by domain and issue area (worksite deportation raids)

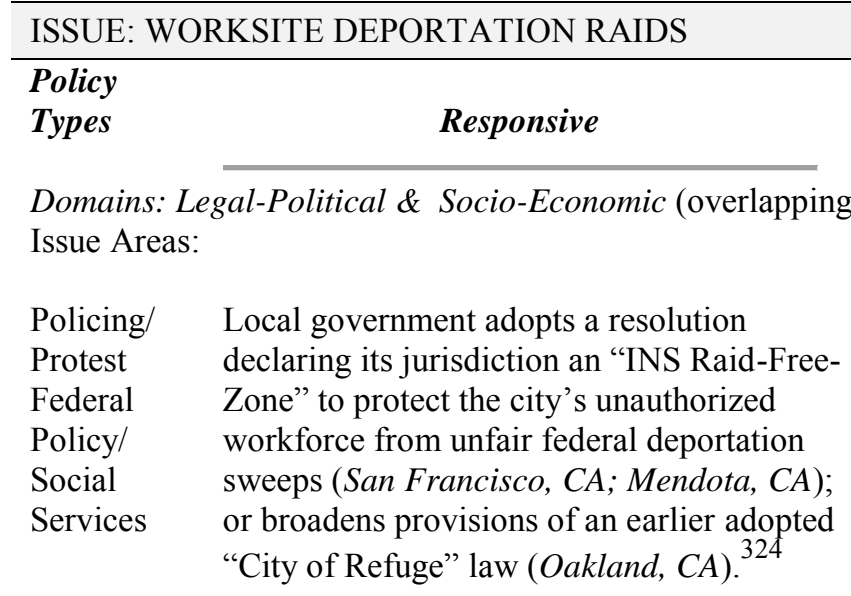

$\stackrel{\sim}{\perp}$

A regional alliance of mayors adopts a resolution asking the U.S. president to suspend raids and deportations of noncriminal immigrants, until "unequal protection" concerns are addressed.

City council awards grant to NGO providing housing for victims of federal immigration raids (Portland, OR), or authorizes foster care for children of raid victims (San Francisco, $\mathrm{CA}$ ).

City officials call for removal of a district INS director, and request a federal investigation of local immigration operations (Portland, OR).

City officials denounce raids at local workplaces (via press conference or letter to congressional representatives) (Santa Fe, NM; Portland, OR; San Rafael, CA).

Police chiefs issue public statements voicing opposition to immigration raids (Austin, TX; Sacramento, CA; LEEI).

City council resolution calls for a moratorium on immigration raids during the Census count (Sacramento, CA).

Mayor declares state of emergency seeking federal disaster relief in the aftermath of an financially devastating immigration raid (Postville, IA).

Mayor urges the distinct INS director to sign a MOU with immigrant advocates promising to shift its focus to criminal, instead of civil, immigration law violations.

\section{Unresponsive}

City council adopts a resolution declaring its jurisdiction an "Illegal-Free-Zone."

Police officers assist federal agents on local immigration raids, or conduct largescale, INS-style deportation raids themselves (Riverside, CA; Mesa, AZ).

Local authorities use a federal racketeering law to sue companies that hire illegal workers (Canyon County, ID).

Mayor writes Secretary of Homeland Security to request local immigration enforcement and deportation help.

City government urges the federal government to approve more funds for immigration law enforcement.

Elected officials ignore complaints from immigrants' rights groups about an abusive INS director and local raid operations.

${ }^{324}$ The original decree only applied to specific refugees from El Salvador, Nicaragua, Haiti, or South Africa.
${ }^{325}$ Los Angeles, CA; Oakland, CA; Seattle, WA; Chicago, IL; Fresno, CA. 
Table 4.1 Typology of municipal unauthorized immigration policy by domain and issue area (devolution of immigration law enforcement)

\begin{tabular}{|c|c|c|}
\hline $\begin{array}{l}\text { Policy } \\
\text { Types }\end{array}$ & Responsive & Somewhat Responsive \\
\hline \multicolumn{3}{|c|}{$\begin{array}{l}\text { Domain: Legal-Political } \\
\text { Issue Area: }\end{array}$} \\
\hline \multirow[t]{4}{*}{ Policing } & $\begin{array}{l}\text { Police department confidentiality order } \\
\text { prevents local law enforcement from } \\
\text { asking about immigration status unless } \\
\text { police make criminal arrest (Sacramento, } \\
\text { CA: Chicago, IL). }\end{array}$ & $\begin{array}{l}\text { Police department does not have a written } \\
\text { policy, but its unofficial procedure is to } \\
\text { "don't ask" about immigration status } \\
\text { during police routine work (Sacramento, } \\
C A \text { ). }\end{array}$ \\
\hline & $\begin{array}{l}\text { Police commission or chief initiates a } \\
\text { police department order limiting } \\
\text { cooperation between police and federal } \\
\text { immigration agents; local law enforcement } \\
\text { prohibited from detecting, arresting or } \\
\text { detaining persons for noncriminal } \\
\text { violations of immigration law. }{ }^{326}\end{array}$ & \\
\hline & $\begin{array}{l}\text { City council adopts a nonbinding } \\
\text { resolution limiting police-INS } \\
\text { cooperation; the decree vows that city } \\
\text { personnel will not be used for immigration } \\
\text { law enforcement purposes. } 327\end{array}$ & \\
\hline & $\begin{array}{l}\text { City officials approve ordinance banning } \\
\text { use of public funds for local enforcement } \\
\text { of civil immigration laws. } 328\end{array}$ & \\
\hline
\end{tabular}

Local law enforcement officers inquire about immigration status during routine police work.

Police department assists federal authorities with federal immigration law enforcement.

\footnotetext{
${ }^{326}$ Los Angeles, CA (1979); Denver, CO; Washington, DC; Portland, OR; New York, NY.

${ }^{327}$ San Francisco, CA; Sacramento, CA; Chicago, IL; Santa Fe, NM; Austin, TX; Dallas, TX.

${ }^{328}$ Berkeley, CA; San Francisco, CA; San Jose, CA; Santa Cruz, CA.
}

\section{Unresponsive}


Table 4.2 Typology of municipal unauthorized immigration policy by domain and issue area (devolutions of immigration law enforcement)

\begin{tabular}{|c|c|c|}
\hline \multicolumn{3}{|c|}{ ISSUE: DEVOLUTION OF IMMIGRATION LAW ENFORCEMENT } \\
\hline $\begin{array}{l}\text { Policy } \\
\text { Types }\end{array}$ & Responsive & Somewhat Responsive \\
\hline \multicolumn{3}{|c|}{$\begin{array}{l}\text { Domain: Legal-Political } \\
\text { Issue Areas: }\end{array}$} \\
\hline $\begin{array}{l}\text { Policing/ } \\
\text { Protest } \\
\text { Federal } \\
\text { Policy/ } \\
\text { Political } \\
\text { Participation }\end{array}$ & $\begin{array}{l}\text { Local government adopts a "Civil Liberty } \\
\text { Zone" resolution opposing sections of the } \\
\text { PATRIOT Act and affirming/reaffirming } \\
\text { their commitment to protect the civil and } \\
\text { human rights of all immigrants. } 329 \\
\text { Police department opts out of federal } \\
\text { investigations of foreign visa overstayers } \\
\text { (San Francisco, CA Chicago, IL; Detroit, } \\
\text { MI; Portland, OR). } \\
\text { City council authorizes the withdrawal of } \\
\text { police officers from the FBI-led anti- } \\
\text { terrorism task force (JTTF) (Portland, } \\
\text { OR). }\end{array}$ & $\begin{array}{l}\text { Mayor and police chief sign contract } \\
\text { pledging vigilant oversight to ensure } \\
\text { confidentially laws are not violated by the } \\
\text { PATRIOT Act (Portland, OR). } \\
\text { Police chief creates a police advisory } \\
\text { council comprised of representatives } \\
\text { from groups targeted by federal agents } \\
\text { for deportation, e.g., Muslim and Arab } \\
\text { visa overstayers, and/or Latinos without } \\
\text { green cards (Portland, OR). } \\
\text { City council member writes Op-Ed piece } \\
\text { in local newspaper defending city's } \\
\text { position on withdrawing police from the } \\
\text { FBI-led JTTF (Portland, OR). }\end{array}$ \\
\hline
\end{tabular}

${ }^{329}$ As of December 7, 2007, 406 cities and counties passed resolutions opposing sections of the USA Patriot Act. See Bill of Rights Defense Committee at: www.bordc.org; and American Civil Liberties Union at: www.aclu.org.

City council convenes public hearings on its JTTF agreement with the DHS, but renews a MOU agreement despite opposition from a majority of citizens (Portland, OR).

Police assist with federal anti-terrorism interrogation of foreign visa overstayers.

Unresponsive 
Table 4.3 Typology of municipal unauthorized immigration policy by domain and issue area (devolution of immigration law enforcement) ISSUE: DEVOLUTION OF IMMIGRATION LAW ENFORCEMENT

\section{Policy}

Types

Responsive

Somewhat Responsive

Unresponsive

Domains: Legal-Political \& Socio-Economic

Issue Areas:

Protest

Federal

City council adopts a nonbinding resolution opposing federal legislation to

Policy/

Policing transfer federal immigration enforcement responsibilities to local police ( $L O S$ Angeles, CA; Boston, MA; Dearborn, MI; Seattle, WA)

${ }^{330}$ Arizona's new immigration law (SB 1070) requires local law enforcement officials and agencies to enforce federal immigration laws.

${ }^{331}$ A list of 57 member cities involved in the Major Cities Chief Association is available at: http://www.majorcitieschiefs.com.

${ }^{332}$ Participating cities as of September 2011: Task Force only: City of Springdale Police Dept. (AK), City of Rogers Police Dept. (AK), City of Danbury Police Dept. (CT), City of Durham Police Dept. (NC), Farmers Branch Police Dept. (TX), Herndon Police Dept. (VA), Manassas Park Police Dept. (VA), Manassas Police Dept. (VA).; Jail Enforcement only: Las Vegas Metropolitan Police Dept. (NV), Carrollton Police Dept. (TX); Jail and Task Force: City of Mesa Police Dept. (AZ), City of Phoenix Police Dept. (AZ), Florence Police Dept. (AZ).
Mayor or city council issues a press release to announce opposition to devolution of federal immigration law enforcement (Dearborn, $M I$ ). ${ }^{330}$

Police department or police chief issues a statement criticizing federal programs (e.g., 287(g), CLEAR Act) to transfer immigration law enforcement authority to local police agencies, or signs a statement issued by the national police chief association (Sacramento, CA; Denver, OR; Portland, OR). ${ }^{331}$

Police department opts out of federa programs deputizing trained police officers to act as immigration agents.
City council adopts ordinance authorizing police participation in the federal officers to arrest and detain unauthorized foreign nationals for noncriminal infractions of immigration law.

Police department signs MOU agreement with U.S. Immigration and Customs Enorcement (ICE) to train police to

Mayor publicly criticizes ICE for ignoring the city's application for $287(\mathrm{~g})$ training to deputize police as immigration agents (Waukegan, IL; Carpentersville, $I L)$ programs that allow trained police 
Table 4.4 Typology of municipal unauthorized immigration policy by domain and issue area (devolution of immigration law enforcement) ISSUE: DEVOLUTION OF IMMIGRATION LAW ENFORCEMENT

\begin{tabular}{|c|c|c|}
\hline $\begin{array}{l}\text { Policy } \\
\text { Types }\end{array}$ & Responsive & Somewhat Responsive \\
\hline $\begin{array}{l}\text { Domain: } \\
\text { Issue Are }\end{array}$ & $\begin{array}{l}\text { gal-Political } \\
:\end{array}$ & \\
\hline $\begin{array}{l}\text { Protest } \\
\text { State } \\
\text { Policy/ } \\
\text { Policing }\end{array}$ & $\begin{array}{l}\text { City council adopts resolution condemning } \\
\text { an ordinance adopted by another city/state } \\
\text { that requires police to check the } \\
\text { immigration status of suspected civil } \\
\text { immigration law violators (Pasadena, CA; } \\
\text { Santa Ana, CA; Brownsville, TX); the } \\
\text { decree urges the governor/mayor to rescind } \\
\text { the measure (San Diego, CA; Tacoma, WA), } \\
\text { or urges lawmakers in their own jurisdiction } \\
\text { not to adopt a similar law (San Antonio, TX; } \\
\text { El Paso, TX). } \\
\text { 333 } \\
\text { City officials pass a resolution calling for a } \\
\text { moratorium on public travel to another } \\
\text { city/state (San Jose, CA; Minneapolis, MN; } \\
\text { St. Paul, MN; New York, NY), or travel } \\
\text { boycott, (Oakland, CA; West Hollywood, } \\
\text { CA; Boulder, CO; El Paso, TX), or full } \\
\text { boycott of companies in that city/state until } \\
\text { its policy on unauthorized immigrants is } \\
\text { repealed (Berkeley, CA; Los Angeles, CA; } \\
\text { San Francisco, CA; Denver, CO; Boston, } \\
\text { MA; Austin. TX; Seattle, WA). }\end{array}$ & $\begin{array}{l}\text { City council sends a resolution to the } \\
\text { White House calling on Congress and the } \\
\text { President to sign comprehensive } \\
\text { immigration reform bill to prevent more } \\
\text { city/state laws from cropping up that allow } \\
\text { police to enforce civil immigration laws } \\
\text { (Sacramento, CA; Denver, CO; New York, } \\
\text { NY). } \\
\text { City manager sends a letter to } \\
\text { governor/mayor of another city/state } \\
\text { telling her/him that their city/state has lost } \\
\text { all business from their city employees } \\
\text { because of its police policy on } \\
\text { unauthorized foreigners (Gallup, NM). } \\
\text { Public school board or superintendent bans } \\
\text { work-related travel to a city/state that } \\
\text { allows police to enforce civil immigration } \\
\text { laws (Denver Public Schools, Los Angeles } \\
\text { Unified School District board, San } \\
\text { Francisco Unified School District board). }\end{array}$ \\
\hline
\end{tabular}

\footnotetext{
${ }^{333}$ Arizona's new immigration requires police to detain people they suspected are in the country illegal and to verify their status with federal officials; it also makes it a state crime to be in Arizona without "immigration papers" and allows people to sue local government or agencies if they believe state or federal law in not being enforced.

City council proposes a resolution denouncing a city/state that boycotts another city/state because it allows police to enforce civil immigration laws (Menifee, CA). 
Table 4.5 Typology of municipal unauthorized immigration policy by domain and issue area (devolution of immigration law enforcement)

\begin{tabular}{|c|c|c|}
\hline $\begin{array}{l}\text { Policy } \\
\text { Types }\end{array}$ & Responsive & Somewhat Responsive \\
\hline \multicolumn{3}{|c|}{$\begin{array}{l}\text { Domain: Legal-Political } \\
\text { Issue Areas: }\end{array}$} \\
\hline \multirow[t]{4}{*}{$\begin{array}{l}\text { Protest } \\
\text { State } \\
\text { Law/ } \\
\text { Policing }\end{array}$} & $\begin{array}{l}\text { City council passes resolution authorizing } \\
\text { city attorneys to provide support for legal } \\
\text { challenges filed by local lawyers against } \\
\text { another city/state that permits local } \\
\text { enforcement of immigration law (San } \\
\text { Jose, CA; Portland, OR). }\end{array}$ & $\begin{array}{l}\text { A boycott against businesses in another } \\
\text { city/state that allows police to enforce } \\
\text { civil immigration is urged but not } \\
\text { prohibited by City Hall (Chicago, } \\
\text { IL). }\end{array}$ \\
\hline & $\begin{array}{l}\text { Elected officials urge voters to reject a } \\
\text { local car impound measure that targets } \\
\text { unauthorized immigrants by requiring } \\
\text { police to impound vehicles operated by } \\
\text { unlicensed drivers, revealing immigration } \\
\text { status (Denver, } C O \text { ). }\end{array}$ & $\begin{array}{l}\text { Police department, or national group } \\
\text { representing big-city chiefs (e.g., LEEI) } \\
\text { hold a news conference to speak out } \\
\text { against cities that allows police to enforce } \\
\text { civil immigration laws; they voice } \\
\text { opposition to 'enforcement only' } \\
\text { policies. }\end{array}$ \\
\hline & $\begin{array}{l}\text { City council repeals car impound } \\
\text { ordinance passed by popular vote (Denver, } \\
C O \text { ). }\end{array}$ & \\
\hline & $\begin{array}{l}\text { Police commission approves a plan to ease } \\
\text { car impound rules unfairly burdening } \\
\text { immigrants without driver's licenses ( } L o s \\
\text { Angeles, } C A \text { ). }\end{array}$ & $\begin{array}{l}\text { Local government does not require police } \\
\text { to enforce a new car impound rule even } \\
\text { though the law requires it (Denver, } C O \text { ). }\end{array}$ \\
\hline
\end{tabular}

Police impound cars of unauthorized immigrants without driver's licenses.

${ }^{334}$ The City of Los Angeles amended its boycott to make an exception for an essential Arizona business operating in the city.

${ }^{335}$ A list of police departments represented by the Law Enforcement Engagement Initiative (LEEI) is available at: http://www.leei.us. 
Table 5.1 Typology of municipal unauthorized immigration policy by domain and issue area (government benefits)

\begin{tabular}{|c|c|}
\hline \multicolumn{2}{|c|}{ ISSUE: GOVERNMENT BENEFITS FOR NONCITIZI } \\
\hline $\begin{array}{l}\text { Policy } \\
\text { Types }\end{array}$ & Responsive \\
\hline \multicolumn{2}{|c|}{$\begin{array}{l}\text { Domains: Legal-Political \& Socio-Economic } \\
\text { Issue Areas: }\end{array}$} \\
\hline $\begin{array}{l}\text { Protest } \\
\text { State } \\
\text { Law/ } \\
\text { Social } \\
\text { Services }\end{array}$ & $\begin{array}{l}\text { City officials urge local citizens to vote } \\
\text { "no" on a local ballot measure (e.g., } \\
\text { California's Proposition 187) that would } \\
\text { deny benefits to unauthorized immigrants } \\
\text { (Sacramento, CA). }\end{array}$ \\
\hline
\end{tabular}

A regional alliance of mayors and county supervisions adopt a resolution calling for a say in the welfare policy debate and more federal funding for cities with large immigrant populations; the decree is sent to state and federal lawmakers (Sacramento, CA).

City council adopts a nonbinding resolution declaring its jurisdiction an immigrant 'Safety Net Zone' to affirm its commitment to provide immigrants access to social services and vow city personnel will not be used for immigration purposes

(Chicago, IL; Santa Fe, NM; Austin, TX; Dallas, $T X)$; other municipalities pass a confidentiality law to add "teeth" to their existing sanctuary resolution restricting the exchange of immigration status information (Takoma Park, $M D$ Minneapolis, MN; Seattle, WA; NYC).
Mayor and/or city council speaks out against an initiative proposed in another state (e.g., Proposition 187) that would deny benefits to unauthorized immigrants; he/she vows to reject local proposals for a copycat measure (Denver, $\mathrm{CO}$ ).

Mayor lobbies the U.S. president and Congress to vote against federal

legislation that would deny benefits to immigrants (Sacramento, CA; Denver, $\mathrm{CO})$.

\section{Unresponsive}

Mayor and city council members urge a "yes" vote on a local ballot measure (e.g., California's Proposition 187) that would deny benefits to unauthorized immigrants.

City passes an ordinance barring unauthorized immigrants from public facilities and services like clinics, libraries and schools (Prince William County). 
Table 5.2 Typology of municipal unauthorized immigration policy by domain and issue area (government benefits for noncitizens)

\begin{tabular}{|c|c|c|}
\hline $\begin{array}{l}\text { Policy } \\
\text { Types }\end{array}$ & Responsive & Somewhat Responsive \\
\hline \multicolumn{3}{|c|}{$\begin{array}{l}\text { Domains: Legal-Political \& Socio-Economic } \\
\text { Issue Areas: }\end{array}$} \\
\hline $\begin{array}{l}\text { Protest } \\
\text { Federal } \\
\text { Policy/ } \\
\text { Social } \\
\text { Services }\end{array}$ & $\begin{array}{l}\text { City administrators file a lawsuit } \\
\text { challenging the legality of federal } \\
\text { legislation prohibiting local government } \\
\text { from restricting the exchange of } \\
\text { information with federal immigration } \\
\text { agents (New York, NY). } \\
\text { City leaders form a partnership with }\end{array}$ & $\begin{array}{l}\text { Local public services agencies do not have } \\
\text { a written confidentiality policy, but their } \\
\text { unofficial practice is "don't ask" about a } \\
\text { client's immigration status. } \\
\text { Local public hospitals vow to keep secret } \\
\text { an immigrants' legal status even after the } \\
\text { municipality's sanctuary resolution is } \\
\text { rescinded (New York, NY). }\end{array}$ \\
\hline
\end{tabular}

county government to guarantee

immigrants' uninterrupted access to social services after federal legislation denies or restricts welfare benefits to immigrants.

City council approves the use of public revenues to guarantee immigrants access to social services denied them by the federal government; no distinction made between legal and unauthorized immigrants (San Francisco, CA; Denver, $\mathrm{CO}$ ), the conditioning of city/county services or benefits upon immigration status is prohibited by law (San Francisco, CA).

City prohibits the use of taxpayer funds to provide social services to illegal immigrants.

City officials cut off funding to local charities/nonprofits that provide services to unauthorized immigrants. 
Table 5.3 Typology of municipal unauthorized immigration policy by domain and issue area (government benefits for noncitizens)

\begin{tabular}{l}
\hline ISSUE: GOVERNMENT BENEFITS FOR NONCITIZENS \\
\hline Policy
\end{tabular}

Types

Responsive

Somewhat Responsive

Unresponsive

Domain: Socio-Economic

Issue Areas:

\section{Social}

Services

\section{City officials issue an executive}

order/ordinance creating a language access

policy that mandates all local public service

agencies offer bilingual services and

materials to clients (Oakland, CA; San

Francisco, CA; New York, NY).

Mayor issues an executive order mandating that all city departments develop formal protocol and training on its 'sanctuary' law (San Francisco, CA).

Mayor launches a city-funded outreach campaign to publicize the city's immigrant "sanctuary" policy to ensure unauthorized residents feel safe when visiting a public health clinic, enrolling their children in school, reporting a crime, or seeking other municipal services; ads available in multiple languages (San Francisco, CA)

Local officials pass a law that requires private businesses providing services to immigrants comply with municipal language access and privacy laws (New York, NY).
Mayor creates an Office of Immigrant

Affairs to help familiarize immigrants

with the city's social services and

programs (New York, NY). 
Table 5.4 Typology of municipal unauthorized immigration policy by domain and issue area (government benefits for noncitizens)

\begin{tabular}{|c|c|c|c|}
\hline $\begin{array}{l}\text { Policy } \\
\text { Types }\end{array}$ & Responsive & Somewhat Responsive & Unresponsive \\
\hline \multicolumn{4}{|c|}{$\begin{array}{l}\text { Domain: Socio-Economic } \\
\text { Issue Areas: }\end{array}$} \\
\hline $\begin{array}{l}\text { Social } \\
\text { Services }\end{array}$ & $\begin{array}{l}\text { City launches a local earned income tax } \\
\text { credit to help mitigate the harmful local } \\
\text { consequences of welfare reform (Denver, } \\
\text { CO; Montgomery County, MD; New York, } \\
\text { NY). } \\
\text { City council adopts a living wage policy }\end{array}$ & & $\begin{array}{l}\text { City adopts a high minimum wage } \\
\text { ordinance for the purpose of ridding the } \\
\text { city of unwanted immigrants; the law } \\
\text { deflects poor, low-skilled workers to } \\
\text { cities that do not enforce labor laws and } \\
\text { have lower wages, because that is where } \\
\text { firms have relocated (Los Angeles, } C A \text { ). }\end{array}$ \\
\hline
\end{tabular}


Table 6.1 Typology of municipal unauthorized immigration policy by domain and issue area ("locally legal" identification cards)

\begin{tabular}{l} 
ISSUE: "LOCALLY LEGAL" IDENTIFICATION CARDS \\
\hline Policy Types
\end{tabular}

\section{Responsive}

Domains: Legal-Political \& Socio-Economic

Issue Areas:

Political

Membership/

Policing/

Social

Services

Mayor issues an executive order authorizing acceptance of foreign government-issued ID cards as official identification; the law instructs the local police department and city agencies to accept it like a state driver's license (Denver, $\mathrm{CO}$ ).

City council approves a resolution endorsing ID cards issued by the foreign consulates (Durham, NC).

Local officials lobby financial institutions for fair access to banking services via acceptance of the foreign government-issued or municipal ID cards.

City issues a municipal ID card to residents regardless of their immigration status; card allows holder to access city facilities and services (San Francisco, CA; New Haven $C T)$.

\section{Somewhat Responsive}

Unresponsive

Police department publicly endorses and/or accepts the foreign governmentissued ID cards, but has no stated policy. 337

Police chief issues a public statement advocating for the state issue of a provisional or non-resident driver's license for unauthorized immigrants (Los Angeles, CA).

Local government studys how and why other cities have implemented a municipal ID card (Oakland, CA; Dayton, $\mathrm{OH}$ )
City council passes a resolution not to endorse ID cards issued by foreign governments (Painesville, $\mathrm{OH}$ )

City council adopts a measure that makes it illegal for local agencies to accept ID cards issued by foreign consulates to access municipal facilities, programs or services.

Local government lobbies for legislation banning foreign government-issued ID cards, and opposes efforts to give foreign in-migrants access to financial services and credit.

\footnotetext{
${ }^{337}$ Phoenix, AZ; Glendale, CA; Colorado Springs, CO; Pueblo, CO; Chicago, IL; Durham, NC; Dallas, TX; Huston, TX; San Antonio, TX.
} 
Table 7.1 Typology of municipal unauthorized immigration policy by domain and issue area (amnesty for unauthorized immigrants)

\begin{tabular}{|c|c|c|}
\hline \multicolumn{3}{|c|}{ ISSUE: AMNESTY FOR UNAUTHORIZED RESIDENTS } \\
\hline $\begin{array}{l}\text { Policy } \\
\text { Types }\end{array}$ & Responsive & Somewhat Responsive \\
\hline \multicolumn{3}{|c|}{$\begin{array}{l}\text { Domain: Legal-Political } \\
\text { Issue Areas: }\end{array}$} \\
\hline $\begin{array}{l}\text { Protest } \\
\text { Federal } \\
\text { Policy }\end{array}$ & $\begin{array}{l}\text { Mayor petitions congressional delegation to } \\
\text { vote against a law that would make illegal } \\
\text { immigration a felony (e.g., HB 4437) and in } \\
\text { favor of a proposed federal amnesty bill. } \\
\text { City council enacts an ordinance urging } \\
\text { Congress to reject immigration reforms that } \\
\text { criminalize individuals because of their } \\
\text { immigration status (Lancaster, } P A \text { ). } \\
\text { Mayor travels to the nation's capital lobby } \\
\text { for a remedy to the citizenship backlog } \\
\text { problem (Sacramento, } C A) \text {. }\end{array}$ & $\begin{array}{l}\text { Members of big-city police chief } \\
\text { associations stage press conferences to } \\
\text { educate the public about the need for } \\
\text { amnesty legislation or other means of } \\
\text { integrating unauthorized immigrants } \\
\text { into the legal system, possibly with a } \\
\text { driver's license (Los Angeles, } C A \text { ). }\end{array}$ \\
\hline
\end{tabular}

Local government urges the U.S. president and their national representatives in Congress to vote against a proposed amnesty bill.

\section{Unresponsive}

